\title{
VERHANDELINGEI
}

VAN HET KONINKLIJK INSTITUUT VOOR TAAL-, LAND- EN VOLKENKUNDE

DEEL $X$

\section{PROEVE VAN EEN \\ BULISCHE SPRAAKKUNST}

\author{
DOOR \\ G. MAA N \\ Oud-Zendeling der Utrechtse Zendings-Vereniging \\ op Halmahera
}

'S-GRAVENHAGE - MARTINUS NIJHOFF - 1951 



\section{VOORBERICHT}

In het voorbericht van mijn ,Boelisch-Nederlandsche Woordenlijst" noemde ik twee namen van personen, aan wie ik veel te danken had bij de samenstelling van die lijst, dezelfde kan ik ook bij het verschijnen van deze „Proeve” weer noemen, maar nu mag en moet ik er nog andere namen aan toe voegen en wel die van Dr. S. J. Esser, die helaas tijdens de Japanse bezetting in een kamp, om het leven is gekomen en die mij bij het samenstellen van deze „Proeve” zo uitnemend heeft geholpen met zijn grote kennis en bekwaamheid. Ere aan zijn nagedachtenis! Voorts die van Prof. Dr. C. C. Berg, die het manuscript heeft willen doorlezen en ondanks veel critiek er op, het toch de moeite waard achtte om het in druk te laten verschijnen, waartoe het Koninklijk Instituut voor Taal-, Land- en Volkenkunde dan ook besloot, en ten slotte die van Prof. Dr. E. M. Uhlenbeck, Secretaris der Redactie-commissie van het Koninklijk Instituut, die er veel tijd en kracht aan heeft gewijd om deze „Proeve” formeel en materieel zo goed mogelijk te maken. Mijn hartelijke dank aan al deze Heren en aan het Koninklijk Instituut.

Met opzet noemde ik mijn werk een „Proeve”. Het kon en mocht niet meer zijn. Ik ben geen taalgeleerde; het is amateurswerk en zelf ben ik er tenslotte van overtuigd, dat het niet meer is dan een eerste „Proeve”.

De Zuid-Halmahera-talen zijn nog slechts gebrekkig bekend en het laat zich aanzien, dat er ook voorlopig geen kans zal bestaan, dat er aandacht aan zal kunnen worden geschonken. Daardoor kan dit werk erlige betekenis hebben. Ik gaf, wat ik geven kon, niet meer en ook niet minder.

Het is 30 jaar geleden, dat ik Buli verliet en daarna heb ik nagenoeg geen gelegenheid gehad, contact met de Buliërs te hebben. Ik moest het daarom met de aantekeningen en gegevens doen, die ik in 1920 meebracht. Dit was vooral wat de klankleer betreft niet zo eenvoudig.

Blaricum 1951.

G. MaAN. 


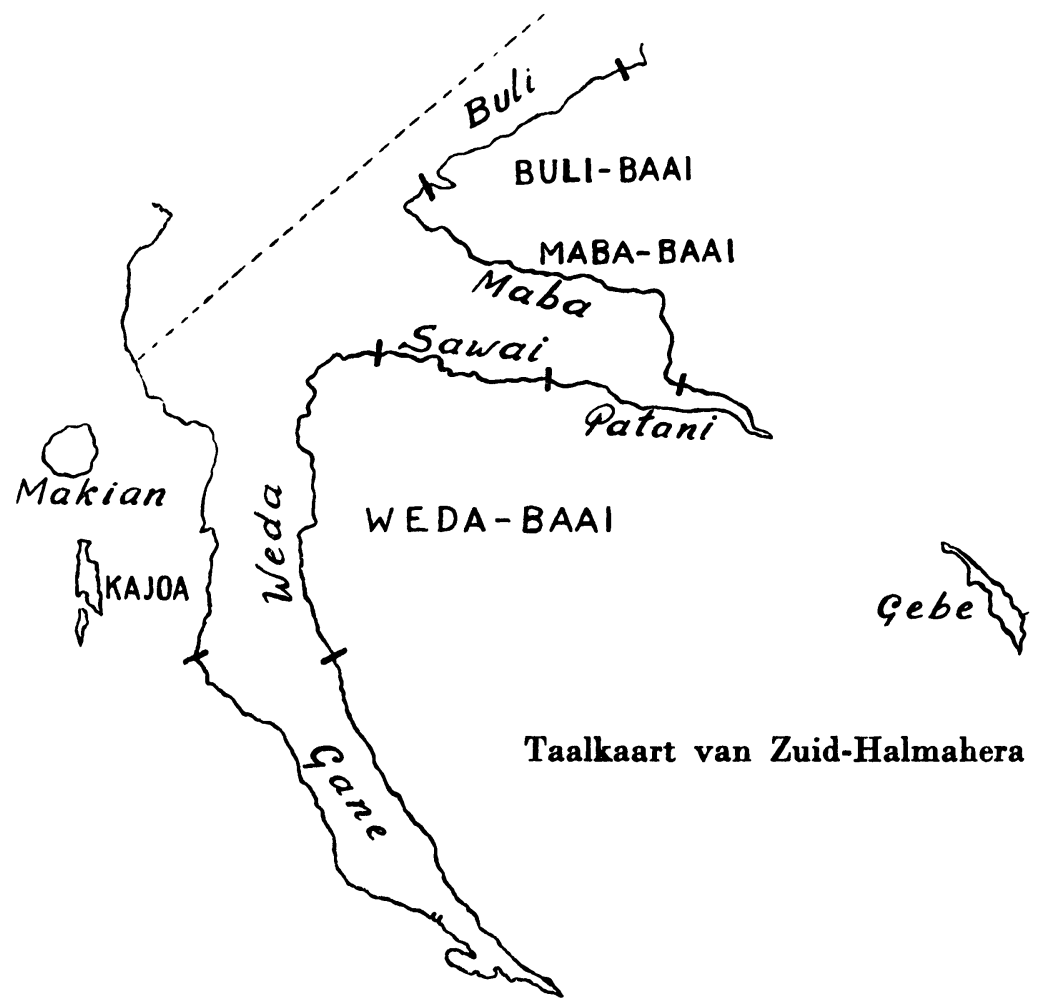




\section{INLEIDING.}

\section{Het Bulisch te midden der talen van Zuid-Halmahera.}

Het vermoeden van Robidé v. d. Aa, reeds in 1872 uitgesproken ${ }^{1}$ ), dat de talen van Zuid-Halmahera tot een andere groep en familie behoren dan die van Noord-Halmahera en omliggende eilanden heeft zich bij nadere kennismaking en voortgezet onderzoek geheel bevestigd ${ }^{2}$ ).

De Zuid-Halmahera-talen behoren tot de Indonesische talengroep meer in het bijzonder tot de Indonesisch-Melanesische overgangs$\left.\operatorname{talen}^{3}\right)$. Zij staan dichter bij de talen van Noord-Nieuw-Guinea en die der Zuid-Molukken dan bij die van Noord-Halmahera.

Zoals op het schetskaartje is te zien, beslaat het Bulisch met het daarbij behorende Jawanli, dat er slechts een variëteit van is, een gedeelte van de N.-O.-kust der Buli-baai. Zij wordt gesproken door de Buli-stam en met geringe wijzigingen ook door de Wajamliërs (Jawanliërs), de twee het Noordelijkst wonende stammen van Zuid-Halmahera, op de N.O.-kust van de Buli-baai. Vroeger woonde de Buli-stam in de Kau-baai op de Westkust van het N.-O.-schiereiland. De Tobelo's hebben hen de Buli-baai ingedreven. Ook in de baai van Dodaga (een onderdeel van de Kau-baai) vindt men nog gezinnen die Bulisch spreken.

Het Bulisch wordt door niet meer dan \pm 1000 personen gesproken $\left.{ }^{4}\right)$. Haar gebied grenst ten Zuiden aan dat van het Maba, dat te zamen met het Bitjoli of Ingli moet genomen worden, daar het verschil tussen beide zeer gering is. Het Maba wordt door \pm 1800 personen gesproken. Aan het gebied van de Maba-Bitjoli-talen grenst dat van het Patani,

1) P. J. B. C. Robidé v. d. Aa, Vluchtige opmerkingen over de talen der Halmahera-groep, B.K.I. 3e volgr. dl. 7, p. 267 (1872).

2) C. A. v. Ophuysen, Maleische Spraakkunst, 2e druk, p. 5.

3) S. J. Esser, T.B.G., LXXV, p. 282-284 (1935). Dr. Esser deelde mij mede, dat hij er de voorkeur aangaf van Austronesisch-Papoese mengtalen te spreken. Zie ook: N. Adriani, De Barese-sprekende Toradja's van Midden-Celebes, III, p. 301, v.v. (1914), en H. v. d. Veen, De Noord-Halmahera'se taalgroep tegenover de Austronesiese talen, diss. Leiden 1915, p. 2 en 220.

4) Geheel ten onrechte worden de Buliërs in de Mededeelingen van het Encycloped. Bureau Afl. XIII, p. 136 (1917) tot de Sawai-stam gerekend. 
dat gesproken wordt door \pm 1900 personen op de spits van het Z.-O.-schiereiland van Halmahera, dus zowel aan de kust van de Bulials aan die der Weda-baai. Aan het Patani grenst in de Weda-baai het Sawai, dat in de zak van de Weda-baai wordt gesproken door \pm 800 personen. Recht ten Noorden daarvan, aan het meest zuidelijk gelegen deel van de Kau-baai in het dorp Ekor en omgeving komt nog een vestiging van Sawai-sprekenden voor, een bewijs, dat de talen van Zuid-Halmahera daar door die van Noord-Halmahera zijn verdreven, wat de bewoners van Halmahera ook nog zeer wel weten. Een groot gedeelte van de Westkust der Weda-baai spreekt het Weda- of Were, dat \pm 900 sprekers telt. In het Zuiden grenst het Weda aan het Gane, dat gesproken wordt door \pm 1500 personen op de spits van het Z.-W.-schiereiland van Halmahera, dus zowel aan de kust van de Weda-baai als aan die van straat Patientie. Er zijn in dit taalgebied veel nederzettingen van Tobelo's. Op het eiland Makian ten Westen van Halmahera worden twee talen gesproken: het Oost-Makians of de taal der "binnendorpen” en het West-Makians gesproken door de „,buitendorpen” op de Westkust.

De Clercq ${ }^{5}$ ) meende, dat de taal van de binnendorpen verwant is aan het Patani- en het Weda. Daarin vergiste hij zich niet. Het is niet bekend, hoeveel personen Makians spreken. Ook op de Kajoaeilanden wordt deels Oost-Makians gesproken.

Het eiland Gebe, dat tussen Z.-O.-Halmahera en de Waigeo-eilanden ligt, is het taalgebied van het Gebe, een Zuid-Halmahera-taal. Zij wordt door \pm 800 personen gesproken.

\section{Spelling en literatuur.}

Het Bulisch wordt evenmin als enige andere Zuid-Halmahera-taal geschreven. De in deze spraakkunst gebruikte spelling is behoudens de in het volgende te bespreken wijzigingen dezelfde als die van mijn Boelisch-Nederlandsche Woordenlijst met Nederlandsch-Boelisch register welke als het derde stuk van deel 74 van de „Verhandelingen van het Kon. Bat. Gen." in 1940 verscheen.

Cambier ${ }^{6}$ ) en Hueting ${ }^{7}$ ) publiceerden reeds eerder min of meer

5) F. S. A. De Clercq, Bijdragen tot de kennis der Residentie Ternate, Leiden 1890 , p. $82-84$.

6) J. P. C. Cambier, Beknopte Woordenlijst van talen op Tidoreesch-Halmahera, B.K.I. 3e volgr. dl. 7 (1872).

7) A. Hueting, Iets over de Ternataansch-Halmahèrasche taalgroep, B.K.I. 7e volgr. dl. 6 (1908), p. 409-411. 
juiste woordenlijstjes. Niet in druk is verschenen een vertaling van de beide Maleise schoolboekjes „Sĕrba Neka” en „Běbĕrapa tjĕritěra Pěroempamaan". Deze vertalingen ontstonden ten bate van de school te Buli. Eerst werden ze vertaald door de kwekelingen, welke vertalingen vervolgens werden besproken met onze voornaamste en beste helper in het Bulisch, Kore Djabibi. Als aanhangsel bij deze Proeve komen enkele Bulische verhalen voor. Deze werden in de school door leerlingen uit de hoogste klasse opgeschreven en daarna met Kore Djabibi besproken. Het was moeilijk deze verhalen los te kijgen; de veelal inleidende formule: „Kolano pnu pusa tede, tede bereá”, d.w.z. de koning in een zekere plaats, men eerbiedige hem maar, wijst op een zekere bevreesdheid.

Verder vindt men omtrent het Bulisch belangrijke mededelingen bij $\operatorname{Dr} \mathrm{N}$. Adriani in zijn werk over de Barese sprekende Toradja's van Midden-Celebes ${ }^{8}$ ), waarvan ik bij het samenstellen van deze Proeve, een veelvuldig en dankbaar gebruik heb gemaakt.

\section{Vreemde bestanddelen.}

Er zijn in het Bulisch verscheidene vreemde bestanddelen opgenomen. Vooral komen er veel woorden in voor, die onveranderd, of met geringe wijzigingen uit het Maleis zijn overgenomen, waaronder weer vele, die ook in het Maleis niet oorspronkelijk zijn.

$a$. Aan het Maleis zijn o.a. ontleend: abar, tijding, bericht (Mal. kabar); adat, gewoonterecht (Mal. adat); adjal, levenseinde (Mal. adjal); ade-ade, gelijkenis, vergelijking (Mal. andai); aiwani, dier (Mal. hewan); akil, vervanger, getuige (Mal. wakil); alipa, achteloos, nalatig (Mal. alpa); Amis, Donderdag (Mal. Kĕmis); asal, afkomst, familie (Mal. asal); asil, opbrengst, oogst (Mal. hasil); awal, vroeger, voorheen (Mal. awal, begin); badagan, handelen (Mal. bĕrdagang); beradosa, zondig, zondigen (Mal. burrdosa); amal, dank (Mal. amal); birahi, aangenaam (Mal. bĕrahi); badan, lichaam (Mal. badan); baladja, huishoudelijke uitgaven (Mal. bělandja); barakat, zegen, heil, geluk (Mal. bĕrkat); bisa, giftig (Mal. bisa); balas, vergelden, wreken (Mal. balas); majeti, lijk (Mal. maït); baraguna, nuttig zijn, nut hebben (Mal. bĕrguna); bawa, ui (Mal. bareang); bingul, in de war zijn (Mal. bingung); kuasa, onderhorigen, macht (Mal. kuasa); dadi, worden, gelukken (Mal. djadi); dadikan, scheppen (Mal. měndjadikan); makse, ofschoon (Mal. maski); daëra, omtrek, streek (Mal. daérah); mardika, vrije (Mal. mardeka);

8) N. Adriani, o.c., III, p. 301-346. 
daulat, zegen, heil, geluk (Mal. daulat); sasi, zweren (Mal. saksi); dramean, lett. zij maken pret, ook: orgel, piano (Mal. ramaian); padoman, bril, kompas (Mal. pĕdoman); akal, bedriegen (Mal. akal, verstand, inzicht, list); faëda, nut, voordeel (Mal. paedah); kalangkuan, gedrag (Mal. kĕlakuan).

Deze voorbeelden zijn nog met vele te vermeerderen. Soms wijzigt zich de betekenis der woorden enigszins, zoals hierboven bij enkele woorden bleek.

Bij overname worden combinaties van nasaal + homorgane orale consonant tot de orale consonant gereduceerd, bijv. : kabil, geit (Mal. kambing); tabako, tabak (Mal. těmbakau); tabaga, rood koper (Mal. těmbaga); tiba, waterschepper (Mal. timba); tado of tadu, hoorn (Mal. tanduk); tuba, lans (Mal. tumbak); padji, vlag (Mal. Tern. pandji); sosobal, rugvin v.e. vis (Makass. sombalá, zeil); malibi, s.v. boom (Mal. bĕlimbing); rate, ketting, keten (Mal. rantai); suba, vereren, aanbidden (Mal. sěmbah).

Anderzijds gebeurt het, dat men in de overgenomen woorden een praenasalering aanbrengt, een verschijnsel, dat overigens in het Bulisch nooit voorkomt; bijv. kalangkuan, gedrag (Mal. kĕlakuan); ronda, wiel, schroef van een schip (Mal. roda); ganding, kromhout v.e. prauw (Mal. gading-gading); kentel, ketel (Mal. Ned. ketel).

Eigenaardig is verder nog, dat men gaarne twee vreemde woorden, die soms synoniem zijn, door het Bulische voegwoord re, en aan elkaar verbindt. Samen krijgen zij dan één betekenis, bijv.: adat re sopan, goede manieren (van Mal.adat en sopan); ali re bangsa, familie, verwanten (van Mal. ahli en bangsa); adat re amal, iemands aard, inborst (van Mal. adat en amal); miskin re hal, arm, gering (van Mal. miskin en hal); kalangkuan re kijafat, aard, wezen (van Mal. kĕlakuan en kaifiat, hoedanigheid); akal re kirakira, gedachten hebben, raad weten (van Mal. akal en kira-kira); suba re sidjur, vereren, aanbidden (van Mal. sěmbah, teken v. verering en Mal. sudjud, eerbiedig neerbuigen); kàngela re siksa, moeiten en zorgen (van Bul.-Tobel. kangela, moeilijk en Mal. siksa, straf, pijniging); untung re faëda, geluk, voordeel (van Mal. untung, winst, voordeel en paédah); using re djamān, voorkomen, houding (van Bul. using, voorkomen, soort en Tobel. djamani, aangezicht, gelaat); mangerti re sogaro, waarschuwen (van Mal. měngĕrti en Noord-Halm. sogaro, opwekken, aansporen); mawa re bersi, rein van hart (van Bul. mawa, ruim en Mal. běrsih); dodoto re fatnau, lering, onderricht (van Noord-Halm. dodoto, onderwijzen en Bul. fatnau, bevelen). 
b. Daar de Buliërs sinds onheugelijke tijden aan de Sultan van Tidore onderworpen waren, verwondert het ons niet ook Tidorese woorden aan te treffen, bijv. ali ma diali, stenen vloer; ali adara, s.v. gebak; bobita, vermanen, bevelen; bòki, prinses; dua-dua, blaasbalg; iddin, vorstelijk bevel; doruino, gast; tino, weven; fola djawa, afgodstempeltje; gogoro, uitnodigen; djobe, aar; djuanga, oorlogsprauw; Djou, Heer; kalero, kalkoven.

c. Aan het Ternataans zijn o.a. ontleend: padji, vlag (door het Tern. uit het Mal.); butu, markt; tenda, winkel; dano, adellijke; dodara, liefhebben ; dou-dou, steiger, brug ; dodano, pand; foloi, veel, meer ; gumilada, touw v. cocosvezel; gosora, muskaatnoot; kailupa, kapok; kasiná, spiegel.

$d$. Door het Tidorees en het Ternataans kwamen ook enige Portugese en/of Spaanse woorden in het Bulisch, bijv. tamate, tomaten; oras, uur; tuala, hoofddoek; kastèla, mais; reāl, reaal; tempo, tijd, toen; mortelu, hamer; popae, papaja.

$e$. Eveneens door het Tidor. en het Tern. kwamen enige Nederlandse woorden in het Bulisch; het is ook mogelijk, dat het Moluks-Maleis er een rol in vervuld heeft. Voorbeelden zijn: agar, hagel; balk, balk; bangko, bank; prom, pronk, sieraad, huisraad; distāt, statiekleding; buk, boek; kamal, kamer; bor, boor; dobel, dubbel ; iskāf, schaaf ; klak, klacht, aanklagen; lampur, lamp; trāl, tralie; snapān, snaphaan; kanapsa, knapzak; sakola, school; palakāt, bevel; kas, kast, kist; sen, cent; fandun, van doen, nodig hebben.

$f$. Zelfs enige Javaanse woorden ontbreken niet, als : mangsi, griffel; djara, paard; bakasa, ingelegde visjes, gezouten vlees of vis; kamasi, ingelegde visjes, garnalen. Ook deze woorden zullen wel door een of ander medium zijn binnengekomen. Dit blijkt volgens Dr Esser ook wel hieruit, dat mangsi in het Javaans niet "griffel” betekent, maar ,inkt".

g. Daar de Buliërs veel met de Tobelorezen in aanraking kwamen, ontbreken ook verscheidene Tob. woorden niet, als: dae, wapen; afa, kaf (dit houdt mogelijk wel verband met het Mal. hempa, naar Dr Adriani vermoedde); pinge, rijst; dopo-dopo, s.v. mes; doro, geul, doorvaart tussen twee riffen; gule-gule, rijstepap; tede, eren.

$h$. Moluks-Maleise woorden zijn: marinjo, factotum v.h. dorpshoofd; bagea, s.v. gebakje; masanai, opvarenden v.e. prauw ; kabata, roeiliedjes zingen; tjagulu, raadsel (Mol.-Mal. tjigulu, id.).

Sommige vreemde woorden zijn zo geassimileerd, dat ze geheel als Bulische worden behandeld, bijv. bitjara, beraadslagen; fabitjaro, met 
elkander beraadslagen over; durakan, overtreden; madurakan, overtreder, misdadiger; balas, vergelden; baltja, vergelden met; untung, winst, voordeel; fauntung, geluk, voordeel aanbrengen; djala, werpnet; fadjala, een werpnet gebruiken; talăk, echtscheiding; fatalāk, van elkander scheiden; njata, openbaar, duidelijk; faso-njata, openbaren, openbaar maken.

Ten slotte vindt men ook enige hybridische woorden, als ai salib, kruis (Bul. ai, hout en Mal. salib, kruis); ai djara-djara, s.v. marteltuig te Tidore in gebruik (Bul. ai, hout en Tid. djara-djara, schraag); besi ma titi, aanbeeld (Mal. běsi en Tid. ma titi, de voet er van); gadja na tepa, ivoor (Mal. gadjah, olifant en Bul. na tepa, zijn slagtand); kawi mulo, bruidschat (Mal. kawin en Bul. mulo, prijs); lobo sadat, wijsvinger (Bul. lobo, vinger en Tid. sahadat, geloofsbelijdenis) ${ }^{9}$ ).

Daar men onder de Buliërs geen standsverschil aantreft, heeft men in het Bulisch ook geen zgn. taalsoorten, zelfs niet in het woord voor de 2de persoon v.h. pers. voorn.w. Door de omgang met vreemdelingen begint men de woorden tuan, njonja en djou enigszins als beleefdheidswoorden voor de 2e persoon v.h. pers. voorn.w. te bezigen.

Ook het in de talen van Noord-Halm. zo sterk aanwezige verschijnsel van 't saali (Gal.) ${ }^{10}$ ) of hohono (Tob.) ${ }^{11}$ ), d.w.z. het bezigen van andere woorden dan de gebruikelijke, om de namen van leden van de aangetrouwde familie niet te noemen, komt in het Bulisch wel voor, doch lang niet zo als op N. Halm.

Op zee en wel bij het oversteken van de zee, bijv. als men van Kaap Lelewi naar Tobelo of Morotai oversteekt, gebruikt men een eigenaardige zeetaal; ook enkele jachttermen ontbreken niet ${ }^{\mathbf{1 2}}$ ). Latan, wind, wordt mimeng, wuiven met een doek; ulan, regen, wordt mairing, koud; sagige, zweet, wordt sisongit, nat; wōl, zon, wordt mfànas, hitte; nga, maan, wordt aitotaf, sterf; tapi, prauw uithozen, wordt limas, aanbrandsel uit een pan schrappen; (Mal. id., doch Sang. limaš̆, Tontemb. limas, Bar. lime, uithozen); seli, eten, wordt bab lewas, een wig tussen iets slaan; dajung, roeien, wordt lebat, met een roeispaan de steven wenden; dau, roeiriem, wordt pagi-pagi, schuimspaan; lampur, lamp,

9) N. Adriani, o.c. p. 338 .

10) M. J. van Baarda, Woordenlijst Galelareesch-Hollandsch met ethnologische aanteekeningen, 1895 , p. 336 en H. Kern, Woordverwisseling in het Galelareesch, B.K.I. 5e volgr. dl. 8 (1893), p. 120-128.

11) A. Hueting, Tobèloreesch-Hollandsch Woordenboek met Hollandsch-Tobeloreesche inhoudsopgave, 1908, p. 167.

12) Zie hierover verder N. Adriani, o.c. p. 334 en id. Sangireesche Spraakkunst (1893), p. 7. 
wordt plangan, licht; soraf tabako, roken, wordt iwa mamajás, rook maken; tamaga, sirih-pinang pruimen, wordt iwa damin, een rode mond maken; (damin is een vis met rode bek);jap, vuur, wordt izwa mfànas, hitte makend; pira, sagoekoek, wordt iwa bali, stopmiddel maken (dit $i w a$ is een oud woord voor "maken, iets doen”, alleen in pantang-taal gebruikt); falai, zeil, wordt opopa, vliegmiddel ; falai, zeilen, wordt opa, vliegen; failān, mast, wordt ai tutuling, alleen staande boom; pelang, prauw, wordt pua gitjo, peulenschil; debo, roer, wordt ian golo, visstaart; salifo, storm, wordt mairing mamàgal, grote koude; batu api, vuursteen, wordt pei mfànas, warm makend.

Jachttermen zijn er voor mandjangan of maidjangan, hert, waarvoor aizeani mlànga, lang dier, en voor bou, varken, waarvoor aizwani gogó, zwart dier, wordt gebruikt. 


\section{KLANKSTELSEL EN SPELLING.}

\section{Het vocalisme.}

Het Bulisch bezit de vocalen $A, E, I, O$ en $U$. Hiervan komen de $A, E$ en $O$ voor ieder in twee varianten. De regels welke het optreden van deze varianten bepalen zijn ons niet geheel duidelijk geworden. In het algemeen lijkt het criterium te zijn het al of niet gesloten zijn van de syllabe. Bij alle drie vocalen doen zich echter een aantal uitzonderingen voor. Het is evenwel zeker dat we met varianten te maken hebben, doordat zij nimmer ten opzichte van elkaar een onderscheidende functie hebben. $\mathrm{Zij}$ zullen daarom in de spelling niet door een afzonderlijk teken worden aangeduid.

Een $a$, welke doet denken aan de vocaal van Ned. kaas komt voor alleen in open lettergrepen, bijv. babalai, tinea imbricata; kakamo, hand, arm; ahai, wat?; mali, te, op; waja, water.

Een $a$, welke gelijkenis vertoont met de vocaal van Ned. kas komt voor in het algemeen alleen in gesloten lettergrepen, bijv. fat, vier; mat, dood; dòram, nacht; wònam, zes. Somt komt deze a echter ook voor in open lettergrepen. Dit zal worden aangeduid door een accent-grave, bijv. mfànas, warm; wàma, jaarvogel; kàngela, moeilijk, zwaar; wàngat, vlees.

Een $e$ welke lijkt op de vocaal van Ned. veel staat vooral in open syllaben, bijv. ise, wie?; lalei, landwaarts; ite, wij, incl.; kaule, in de hand dragen; seli, eten.

Een $e$ welke het midden houdt tussen de vocaal van Ned. hek en die van Ned. $i k$ staat in gesloten, maar soms ook in open lettergrepen bijv. fen, zeeschildpad; em, zien; tebteb, zwaar; del, volgen; agel, bijten. Het komt mij voor dat er bij deze $e$ nog allerlei variaties voorkomen, waarbij men nu eens aan Ned. $i$ van $i k$, dan weer aan $e$ in Ned. hek denken moet. Waarschijnlijk bezit deze klank veel overeenkomst met de $e$ welke in het Bare'e voorkomt ${ }^{13}$ ). Waar deze $e$ staat in open syllaben, zal dit aangeduid worden met een accent grave ter onderscheiding van de normale $e$-variant in open lettergrepen, bijv. djalèna, venster; nenèna, klein; tjitjèrek, hurken.

13) N. Adriani, Spraakkunst der Bare'se-taal, Verh. Kon. Bat. Gen. dl. 70 (1931), p. 18 en 19. 
Een $o$, welke lijkt op de vocaal van Ned. loop, komt hoofdzakelijk voor in open lettergrepen, bijv. boboko, hoofd; bo, zullen, opdat; ifo, zwager.

Een $o$, welke gelijkenis vertoont met Ned. hok komt voor in gesloten en slechts in enkele gevallen in open lettergrepen, bijv. gokgok, kraai; dom, drinken; nok, aap; tol, drie; og, kruishout. Waar deze $o$ voorkomt in open lettergrepen, wordt dit aangeduid met een accent grave, bijv. dòram, nacht; wònam, zes; tò, afgelopen; tòtò, afgedaan.

De $i$ en $u$ lijken sterk op de vocalen van resp. Ned. riep en boek, bijv. fit, zeven; lim, vijf ; tig, werpen; uit, pees; tuli, slapen; silek, scheel; $u t$, haarluis, meu, gijlieden.

Naast de vijf bovengenoemde vocalen komen nog voor een gerekte $a, e, i, o$ en $u$, die aangehouden wordt tot de tijd, waarin men bijna twee lettergrepen hoort. $Z \mathrm{ij}$ komen uitsluitend voor in de laatste lettergreep van een woord, terwijl op deze vocalen altijd de klemtoon valt. Zij worden hier aangeduid met een lengteteken, dus als $\bar{a}, \bar{e}, \bar{i}, \bar{o}$ en $\bar{u}$, hoewel het de vraag is of men hier inderdaad met lange vocalen te maken heeft. Voorbeelden zijn: $m \bar{a} n$, man, mannelijk; $p \bar{a} t$, steen; $s \bar{a} l$, fout, mis ; fān, gaan; $t \bar{a} l$, ei ; māng, droog; kakalā, rood; $h n j \bar{e}$, moeder;

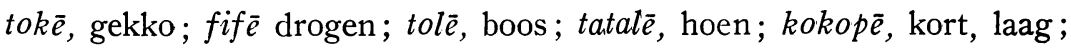
$\bar{\imath}$, slijpen; malī, hierheen; asbì, cassave; $\bar{\imath}$, paal; wōl, zon, dag; tō, weten; saglü, slang; sajū, kiekendief ; amt $\bar{u}$, vast, sterk.

Bij éénlettergrepigen kan zich soms het geval voordoen dat twee woorden van elkaar onderscheiden worden uitsluitend door de tegenstelling van een gerekte tegenover een niet-gerekte vocaal, bijv. $f a$, een piefix: $f \bar{a}, \operatorname{rog} ; s a$, één: $s \bar{a}$, rif ; $a m$, een prefix: $\bar{a} m$, algemeen; $t \grave{o}$, afgelopen: $t \bar{o}$, weten. Apang, rijstschuur, onderscheidt zich van $a p \bar{a} n g$, kinds, behalve door de niet-gerekte slotvocaal, ook door de plaats van het accent. Zo ook: mane, weerwolf, boos gedrocht: mane, treiteren; bala, onderdaan: balā, een goed soort timmerhout; mali, te, op: malī, hierheen.

$\mathrm{Bij}$ aanhechting van de possessieve pronomina $k$ (1ste pers.) en $m$ (2de pers.) treedt de $\grave{a}$ en de $\dot{o}$ inplaats van een gerekte $\overline{\mathrm{a}}$ of $\overline{\mathrm{e}}$, bijv. van $h m \bar{a}$, vader, jahmàk, mijn vader, ahmàm, uw vader; van $m t \bar{a}$, oog, jamtàk, mijn oog, amtàm, uw oog; van fiā, dijbeen, jafiàk, mijn dijbeen, afiàm, uw dijbeen ${ }^{14}$ ). Gaat het grondwoord echter uit op een $\overline{\mathrm{e}}$, dan blijft bij aanhechting van deze suffixen, de gerekte è gehandhaafd, bijv. van $h n j \bar{e}$, moeder, jahnjēe, mijn moeder, ahnjēem, uw moeder.

14) $\mathrm{Zie}$ verder Hoofdstuk IV van de vormleer. 
Als twee gelijke vocalen op elkaar volgen, blijven beide, hoewel geen hamza gehoord wordt, duidelijk hoorbaar, bijv. jatai, lever; faifailo, handpalm; pao, half ; falai, zeil ; lau, ver; pepeo, speeksel; sisei, haarkam; meu, gijlieden; kloi, walvis; sasagou, baard; uit, pees; sei, snot; bou, varken.

Tweeklanken kent het Bulisch niet. In tegenstelling met de spelling welke in mijn woordenlijst gevolgd is, zal geen gebruik gemaakt worden van een trema om dit in de spelling aan te duiden. Volgen twee ongelijke vocalen op elkaar, dan wordt, zo de eerste een $u$ is, een lichte overgangs- $w$ gehoord, en zo de eerste een $i$ is, een lichte overgangs- $j$, die beide niet in de spelling worden weergegeven.

\section{Het consonantisme.}

De volgende consonanten worden onderscheiden:

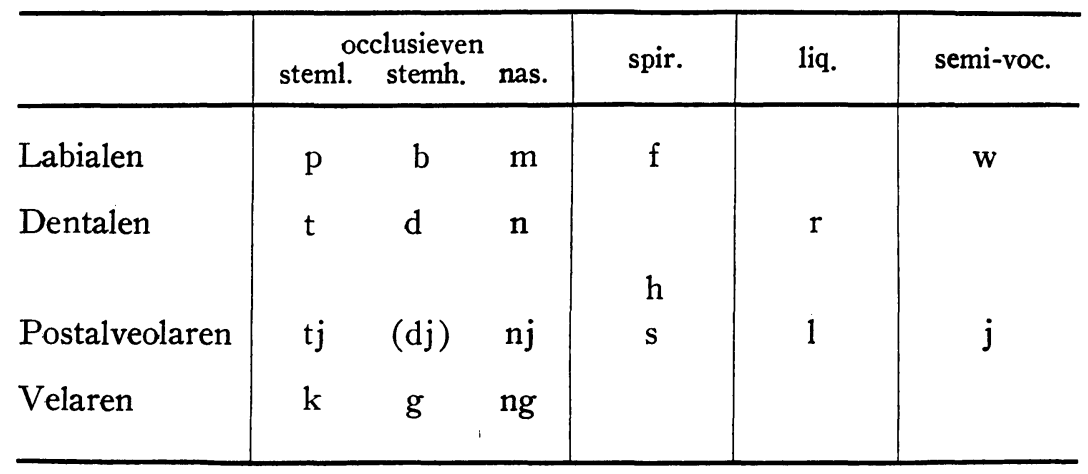

De labialen $p, b, m$ en $f$ komen in alle posities in het woord voor. De $f$ is een bilabiaal.

Voorbeelden zijn: pero, rand, oever; papa, mier; kopolau, spin; pitpitas, kuit; soip, sagoepap; top, suikerriet; upupa, blaasroer; jap, vuur; solop, zolder; bak, vol ; bubuláng, wit ; bibisil, honger, hongerig; $t u b$, leven; tebteb, zwaar; jabat wond; māng, droog; mumuan, leeg; mamajas, rook; janam, vlechten; dom, drinken; wàma, jaarvogel; fafan, plank; fofoas, steenpuist ; afa, kaf ; gafi, schor, hees; jataf, dak; laflaf, bloed.

$T, d$ en $n$ zijn supradentalen of alveolaren. De tong komt met de punt tegen het tandvlees der boventanden. $Z \mathrm{ij}$ worden op een iets hoger plaats uitgesproken dan de Nederlandse dentalen. $T$ en $n$ komen in alle 
posities voor; $d$ staat nimmer in slotpositie. Voorbeelden zijn: tatmān, schouderblad; teno ,broeder; mtā, oog; jatai, lever; uit, pees; dom, drinken; debo, roer; sadakala, hagedis ; nau, arènpalm; nok, aap; mani, vogel ; mna, zoet, lekker; sasun hoek.

Zoals in verschillende andere Indonesische talen heeft men geen palatalen, maar postalveolaren. Deze klanken worden niet gevormd bij het eigenlijke palatum, maar op een lagere plaats: bij de wortels der boventanden. De postalveolaren komen alleen voor in begin- en middenpositie. De $d j$ komt alleen voor in een aantal leenwoorden. Voorbeelden zijn: tjutjut, rijststamper; tjit, de drie haardstenen; otje, geven; tagoltjo, s.v. schelpdier; batju, bijl; njaok, miauwen; kanjo, oor; njinjen, zand. Voorbeelden van leenwoorden met $d j$ zijn: djalèna, venster; kardjäng, werk; padji, vlag; djara, paard; mandjangan, hert; popodje, hoofdkussen; tadju, verlengstuk van het kromhout van een vaartuig; karadja, mand. Ook in djobe, aar, en djegeri, palmrolmarter, loewak, komt de $d j$ voor; wellicht blijkt later, dat ook deze woorden zijn overgenomen ${ }^{15}$ ).

De velaren $k, g$ en $n g$ komen in alle posities voor. Voorbeelden zijn: kitkitan, ooghaartjes; kòri-kòri, klein; sake, strooien; oka, vocht doorslikken; dak, koken; pilok, blind; bak, vol; glao, keel; giglo, oksel; gogó, zwart; waga, cocos; ogog, s.v. djamboe; tig, werpen, gooien; ngengeo, wang; angangi, kies; wàngat, vlees; sanglo, antwoorden; $d u$ ping, ontmoeten. De $k$ wordt aan het einde zeer zacht uitgesproken. De $g$ komt in eindpositie slechts een enkele maal voor.

De $s$ is een stemloze supradentale sibilant, welke veel voorkomt zowel in begin- als in midden- en eindpositie. Voorbeelden zijn: smat, mens; sasagou, baard; sus, borst, mammae ; usi, rib ; sisop, baden; loas, neet ; kos, nauw.

Met $h$ wordt voorgesteld een spirant, die geheel door de neus wordt uitgesproken. De klank wordt gevormd als Ned. $h$, maar de luchtstroom wordt door de neus uitgelaten, terwijl de mond open blijft. Hij staat vooral voor nasalen, bijv. $h m \bar{a}$, vader; $h n j \bar{e}$, moeder; ngahnjo, naam, maar komt ook voor in beginpositie voor vocalen en in middenpositie, maar nooit in eindpositie.

De $w$ is een bilabiale halfklinker, welke de $u$ zeer nabij komt. In sommige gevallen aarzelt men of men $w$ of $u$ moet schrijven. De $w$ komt alleen voor in begin- en middenpositie, bijv. wao, hals; wos, voor-

15) In het Tidorees is ndjobe, aar. De woorden pinge, rijst en afa, kaf, zijn uit het Tobelorees overgenomen. De Buliërs beoefenen de rijstbouw vrijwel niet. 
ouders; wawai, kind; bawa, deur. In eindpositie komt ze niet voor. Als men denkt haar te horen, blijkt het toch een $u$ te zijn, bijv. weu, tros vruchten; bou, varken.

De $j$ is een palatale halfklinker alleen voorkomend aan het begin van een lettergreep, bijv. jap, vuur; $j \bar{a} l$, halen, nemen; ojang, traan; mamajata, lui ; majana, licht, niet zwaar.

De $l$ is van hetzelfde geslacht als de $j$. Deze klank komt veel voor in alle posities, bijv. lobo, vinger; lio, stem; seli, eten; totoláng, zitten; toblo, opnemen; piling, graf; ulang, garnaal; owil, koorts; mamàgal, groot; sagigil, dragen onder de oksel.

De $r$ lijkt veel op de Ned. tong-l en komt in alle posities voor, in beginpositie echter niet frequent.

\section{Klemtoon.}

Veelal valt de klemtoon op de voorlaatste lettergreep, bijv. lóbo, vinger; séli, eten; waréái, kind; sadakála, hagedis; saláwe, losmaken. Is dit het geval dan wordt dit in de spelling niet tot uitdrukking gebracht.

Op de laatste lettergreep valt de klemtoon altijd, indien de slotvocaal gerekt is, bijv. kakanū, eczeem; malī, herwaarts; kakalā, rood. Ook dit wordt in de spelling niet door een afzonderlijk teken aangeduid. Soms echter valt het accent op de slotsyllabe zonder dat deze een gerekte vocaal bevat, bijv. kakanin, zuur; totoláng, zitten; gagalúm, week; pupuráng, wan; gaglí, mager. Slechts in die gevallen zal dit door middel van een accent aigu worden aangegeven.

\section{Spelling.}

In hoofdzaak is in deze spraakkunst dezelfde spelling gevolgd als in de door mij gepubliceerde woordenlijst. De volgende wijzigingen zijn echter noodzakelijk gebleken :

1. I.p.v. oe zal steeds $u$ geschreven worden.

2. De klemtoon wordt in slotsyllaben niet aangeduid met een accent circonflexe, maar met een accent aigu.

3. Ter onderscheiding van de postalveolaren zullen combinaties van $t, d, n$ met een $j$, die kunnen voorkomen wanneer een met $j$ beginnend grondwoord gecombineerd wordt met de pronominale prefixen $t$ (le pers. mv.), $d$ ( $3 \mathrm{e}$ pers. mv.) en $n$ ( $3 \mathrm{e}$ pers. ev.), 
aangeduid worden als $t-j, d-j$ en $n-j$. Bijv. van $j a s$, zwemmen, $t-j a s$, wij zwemmen, $d$-jas, zij zwemmen, $n$-jas, hij zwemt.

4. Ter onderscheiding van de velare nasaal zal de combinatie $n$ met $g$, die kan voorkomen, wanneer een met een $g$ beginnend grondwoord met 't pronominale prefix $n$ wordt verbonden, aangeduid worden met $n$-g, bijv. van gon, kopen, $n$-gon, hij koopt.

5. Zoals hierboven reeds opgemerkt is, zal geen trema gebruikt worden.

\section{Enige opmerkingen van taalvergelijkende aard.}

De $a$ is in 't algemeen gelijk aan de Indonesische $a$, bijv. $m t \bar{a}$, oog: Mal. mata; fat, vier: Jav. pat; wai, acht: Tontemb. watu; ahai, wat?: Mal. apa; malī, hierheen: Mal. mari; sãl, fout, mis: Mal. salah; mfànas, heet: Mal. panas.

$\mathrm{A}$ in het Bulisch correspondeert soms met $o$ en $e$ in andere talen van Zuid-Halmahera, bijv. in het Maba, Patani en Sawai. Voorbeelden zijn: jabat, wond: Mal. jobot, Saw. jobèt, Pat. jobot; man, man: Mab. mon, Saw. mon, Pat. mon.

De $e$ is doorgaans niet oorspronkelijk. Gedeeltelijk is zij ontstaan uit $i$, bijv. fen, zeeschildpad: Saw. fin; jeli, stroomaf: Mal. ilir; meu, gijlieden: Austron. miu; et, vlot: Pat. jit, Mal. rakit; tet, brug, vlonder: Mal. titi.

Samengetrokken uit $a i$ is de $e$ in ise, wie? Oorspronkelijk is ze in klanknabuotsingen: tatale, kip; toke, gekko.

De $i$ is in de eerste plaats de Indonesische $i$, bijv. fit, zeven: Jav. pitu; lim, vijf, Mal. lima; langit, hemel, uitspansel: Mal. id.; lilifáng, duizendpoot: Mal. lipan; mafia, goed, mooi: Sang. mapia; ting, aangaan, aanleggen: Mal. singgah.

Soms komt de $i$ voor waar ze uit $e$ ontstaan kan zijn, bijv. mdalim, scherp: Boegin. tarēng; laling, weg: Boegin. lalēng; pitpitas, kuit: Mal. bětis.

De $o$ is grotendeels niet oorspronkelijk. Vooreerst vertegenwoordigt ze de pěpět, die het Bulisch niet kent. Voorbeelden zijn: top, suikerriet: Mal. těbu; tol, drie, Jav. tělu; wònam, zes: Mal. ěnam; tolo, ei: Mal. tẹlu; mlònga, horen: Mal. dĕngar; mòsi, verzadigd: Tontemb. wěsu; wōl, dag, zon: Sang. ĕllo, Minah. ěndo.

Verder correspondeert zij soms met $a$ blijkens ifo, zwager: Mal. ipar; aibobang, vlinder: Parig. kalibamba; dòram, nacht: Mal. dalam, 
malam; bou, varken: Bar. wareu; gokgok, kraai: Mal. gagak; wōl, zon, dag: Mak. allo.

Tenslotte correspondeert $o$ met $u$ in andere Indonesische talen, bijv. smo, mond, bek: Tontemb. semur; tado, hoorn: Mal. tanduk; tolo, ei : Mal. těllur.

De $u$ is in het algemeen oorspronkelijk, bijv. nus, eiland: Jav. nusa; sus, borst: Mal. susu; uta, hoofdhaar: Sang. uta'; amtuli, slapen: Mor. turi; tub, leven: Mal. tumbuh; pun, doden: Mal. bunuh; ulan, regen: Mal. udjan; ut, haarluis: Mal. kutu; tun, kleerluis: Mal. tuma; ulang, garnaal: Mal. udang.

De $p$ in begin- en eindpositie vertegenwoordigt dikwijs $b$, bijv. pun: Mal. bunuh; pau, geur: Mal. bau; pupungan, nok v.e. dak: Mal. bumbungan; pāt, west: Mal. barat; piai, krokodil: Mal. buaja; pät, steen: Mal. batu; plu, veer, haar: Mal. bulu.

Een woord dat in de Indonesische talen uitgaat op een vocaal, verliest deze vaak in het Bulisch en komt dan op een consonant te sluiten. Indien deze consonant een $b$ is, correspondeert met haar in het Bulisch een $p$, bijv. top, suikerriet: Mal. těbu; gigiáp, as, waarvan $a p=$ Mal. $a b u$.

De $f$ correspondeert vaak met $p$ in de Indonesische talen ten Westen van Halmahera, bijv. fafan, plank: Mal. papan; afa, kaf: Tob afa: Mal. hempa; fni, vleermuis: Mak. paniki; fāa, rog: Mal. pari; fen, schildpad: Mal. pĕnju; jataf, dak: Mal. atap; jafi, kalk: Mal. kapur; fis, hoeveel: Jav. pira; mfànas, warm: Mal. panas; fat, vier: Jav. pat; fit, zeven: Jav. pitu; fun, hond: Sang. kapuna'; lilifáng, duizendpoot: Mal. lipan; fia, goed, mooi: Sang. pia, Mak. pia, genezen.

In verschillende woorden blijkt de $k$ in het Bulisch te zijn uitgevallen, bijv. ut, luis: Mal. kutu; ian, vis: Mal. ikan; utan, vragen: Mak. kuta'snang; ulan, pot,pan; Barese kura, Minah. kure; ān, eten: Mal. makan; fni, vleermuis: Mak. paniki; ja, ik, mij: Barese jaku; ite, wij, incl.: Sang. kite', Mal. kita; ame, wij, excl. : Mal. kami; usi, rib: Mal. rusuk; mani, vogel: Jav. manuk; as, dakspar: Mak., Bare's kaso.

De $h$ is uit $s$ ontstaan, zoals vergelijking met de Maba-, Patani-, Sawai- en Gebe-talen leert: $h m \bar{a}$, vader, $h n j \bar{e}$, moeder: Nuf. sna, Mab. sja; ngahnjo, naam: Geb. ngahno of ngasno, Saw. ngosnu; uhngo, aangezicht (van using, soort, voorkomen): Mab. usnu; fahle, achteroverleunen: Saw. fesle; peiaha, peiahai, waarom, waarnaast staat: pejasa.

In uahleo, oud man, samengesteld uit uat, man, en leo, oud, is de $h$ waarschijnlijk uit $k$ ontstaan, nadat de oorspronkelijke $t$ in $k$ was 
overgegaan, vgl. ahlen en Saw. eklen, Geb. aklen, op de rug liggen; en ohmo, schoonouders: Geb. kmo.

In een aantal woorden blijkt $j$ in het Bulisch in beginpositie voor te komen, waar de corresponderende Indonesische woorden met een vocaal beginnen, bijv. jataf, dak: Mal. atap; jatai, lever: Mal.-Polyn. atai; jap, vuur: Mal. api; janam, vlechten: Mal. anjam; jeli, vloeien: Mal. ilir; jāl, nemen: Mal. alap; jàfa, tiental: Geb. afa.

Het schijnt, dat deze $j$ zich op dezelfde wijze uit de begin $a$ heeft ontwikkeld als de $w$ in het Gorontalees bij woorden als wadala $=$ adjaran, paard; wala's $=$ anak, kind, en evenzo in het Bulisch $w \bar{o} l=$ alo, zon, dag: Mak. allo; wònam, zes: Mal. ěnam. De $j$ heeft dan geen grammatische betekenis ${ }^{16}$ ).

De $l$ blijkt te corresponderen met de Indonesische $l, d, r, d j:$ ulan, regen: Jav. udan, Mal. hudjan; ulang, garnaal: Mal. udang; tol, drie: Jav. tělu; lim, vijf : Mal. lima; lu, twee: Mal. dua; lī, paal, waarmee volgens Dr. Esser correspondeert Koelawisch arii (uit arii) : Mal. diri.

Uit woorden als sus, borst; si, pers. vnw. 3e pers. mv.; usi, rib; tangis, schreien; loas, neet, blijkt dat de $s$ in het algemeen de Mal.Polyn. $s$ is.

In tegenstelling tot de vocalische talen ten Westen van Halmahera en in overeenstemming met de talen van Noord-Nieuw-Guinea vindt men in het Bulisch éénlettergrepige op een consonant uitgaande woorden, welke corresponderen met oorspronkelijk tweelettergrepigen met open eindlettergreep, bijv. sus, borst: Nuf. id., Mal. susu; top, suikerriet: Nuf. kop, Mal. těbu; tol, drie: Nuf. kior, Jav. tělu; lim, vijf : Nuf. rim, Mal. lima; fit, zeven: Nuf. fik, Jav. pitu; wai, acht: Nuf. war, Saw. wal, Mal.-Polyn. walu; mat, dood: Nuf. mar, Mal. mati; lof, vadem: Nuf. rof, Mal. depa; jap, vuur: Nuf. Radj. Empat. lap, Mal. api; tub, leven: Bar. tuwu, Mal. tumbuh; pun, doden: Mal. bunuh; as, dakspar: Bar., Mak. kaso; māl, geklopte boomschors: Nuf. mar, Bar. umajo; tet, vlonder: Mal. titi, Min., Mak. tete; dak, koken: Nap. daka, Bar. djaka, Minah. rakan; fun, hond: Sang. kapunas, Kailisch kapuna, krokodil; ut, luis: Nuf. uk, Mal. kutu; tum, kleerluis: Mal. tuma; fen, schildpad: Nuf. Radj. Empat. id., Mal. pěnju; nus, eiland: Jav. nusa, Tobel. nuhu; ai, hout: Nuf. id., Tomb. kai, Mal. kaju; pāt, steen: Nuf. Radj. Empat. kapat, Patan. kipat, Mal. batu. In het Bulisch worden, evenals in het Nufoorsch en verwanten, ten-

10) Zie verder N. Adriani, De Barese sprekende Toradja's van Midden-Celebes d1. III, p. 329 en 340 . 
gevolge van de klemtoon, die in vele Bulische woorden op de laatste lettergreep valt, van de lettergrepen, die vóór de beklemtoonde staan, de klinkers dikwijls onderdrukt, zodat de medeklinkers, die oorspronkelijk twee opeenvolgende lettergrepen begonnen, een verbinding (ligatuur) aangaan, die bijv. in de Indonesische talen ten Westen van Halmahera niet mogelijk zou zijn. Het is niet altijd mogelijk met beslistheid uit te maken, welke klinker in elk dezer gevallen is verdwenen, maar in de volgende voorbeelden is de vroegere vorm met zekerheid vast te stellen: mta, oog, uit mata, Mal. mata; smo, mond, uit sumo, Tontemb. semur, Saw. sumu; plu, lichaamshaar, veer, uit pulu, Mal. bulu; saslī mazelen, uit sasalū, reduplicatie van salū; papleo, tong, uit papaleo, redupl. van de stam paleo; giglo, oksel, uit gigilo, vgl. sagigil, onder de oksel dragen; sanglo, antwoorden, uit sangalo, vgl. Saw. songel, dat voor sangal staat; tatmān, schouderblad, uit tatamān, redupl. van tamān; màglo, tak er van, schouder, uit magàlo, vgl. mamàgal, groot; wangto, vlees, inhoud, uit wàngato, van wàngat, vlees, inhoud; paplaki, naald, uit papalaki, redupl. van palaki, vgl. Tobel. popilaki; pnu dorp, Nuf. menu, id.; wahle, misschien, uit wahale, vgl. Saw. hale, misschien; smengit, afgestorvene, dodenziel, vgl. Bat. sumangot, Mal. sěmangat.

Ook in vreemde woorden wordt de klinker van de lettergreep, die aan de beklemtoonde voorafgaat, soms onderdrukt, bijv. $a s b \bar{\imath}$ (asbi staat voor kasbi, uit kasubi (klemtoon op su) en kasubii, (Barese), uit cassave; kastèla, (mais), uit kasitèla (kasitela uit „Castilia”, d.i. Spanje, Spaans ${ }^{17}$ ).

\section{Woordvorm.}

Een woord bestaat in het Bulisch ò uit een enkel grondwoord bijv. $s a$, één; tol, drie; fit, zeven; jataf, dak; pio, vrucht; salawe, losmaken; jatai, lever; tjopai, s.v. vis; sadakala, hagedis ;

òf uit een verdubbeld of geredupliceerd grondwoord ${ }^{18}$ ), bijv. laf-

17) Vgl. N. Adriani, De Barese sprekende Toradja's van Midden Celebes, III, p. 388 , noot 2 .

In verschillende talen van de Archipel treft men dit woord aan in tal van vormen: kasitela, kahitela, kastela, kastera, koestela, kastel, pastela, mantela, katela, katila, kasela, kentila, atela, tela en misschien ook kates (Jav.). Zoowel mais (Bul. kastela òsal) als bataten (Bul, kastela rakrak), papaja, Spaanse peper en cassave worden er mee aangeduid. Men zie slechts De Clercq's „Nieuw Plantkundig Woordenboek voor Ned. Indië.

18) Volledige geminatie komt alleen voor bij éénlettergrepige stammen; bij meerlettergrepige komt onvolledige geminatie of reduplicatie voor. Vele namen 
laf, bloed; teb-teb, zwaar; ban-ban, geel; kakamo, hand; boboko, hoofd; òf uit een al of niet verdubbeld of geredupliceerd grondwoord gecombineerd met één of meer affixen, bijv. amjou-jou, heen en weer schudden; fadingidingi, kinderliedjes zingen voor; fakoskoso, nauw maken voor, elkaar benauwen;

òf uit een combinatie van twee woorden, bijv. ailoló, bos, van $a i$, boom, en loló, in, binnenste; uahleo, oudje, van uat, man, en leo, oud; ngololeo, oudje (vrouw), van ngolo, vrouw, echtgenote, en leo, oud; smopero, lippen, van smo, mond, en pero, rand; wagapio, cocosnoot, van raga, cocos, en pio, vrucht; aisalib, kruishout, van ai, hout, en salib, kruis.

Slechts pre- en suffixen komen voor. Infixen zijn door mij niet aangetroffen.

De prefixen zijn: $a, a f, a m, e n ; m, f a, m a, d a, t a, k a($ ?), la; mara, fai en pop.

De suffixen zijn: $a, e, o, i$; ea, eo; an (?), ang (?) en ta. Hier komen dan nog bij de pronominale pre- en suffixen ${ }^{19}$ ).

Alle vocalen en alle consonanten met uitzondering van $d, j$, $w$ en de postalveolaren kunnen in eindpositie voorkomen. Men gebruikt gaarne als steun bij de uitspraak een vrij zachte pěpět achter allerlei woorden, die op een medeklinker uitgaan. Zeer dikwijls is dat het geval, wanneer op zulk een woord het woordje tò (al, afgedaan) volgt. Voorbeelden

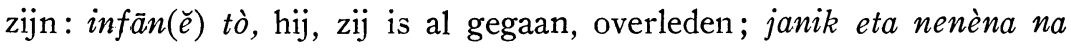

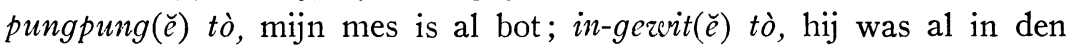

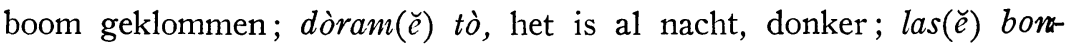
maraparwil, bijna zou hij vallen, gevallen zijn; $d f o i ~ \bar{a} n(\breve{e}) g a$ dān, zij

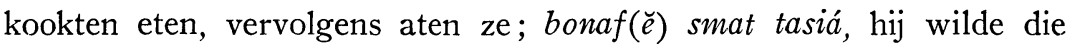
mensen tegenspreken; $\operatorname{hmam}(\breve{e})$ nololau, uw vader roept; dirantja $\operatorname{smat}(\breve{e})$ nean, een deel de mens hij verzorgt; $m j \bar{a} l(\breve{e})$ nak waga taie, haal deze mijn cocosnoot; $\operatorname{Adam}(\breve{e})$ ire Hawa atoláng mali bèt Fir-

van lichaamsdelen zijn met reduplicatie gevormd, waarschijnlijk om ze als werktuignamen te karakteriseren. Voorbeelden daarvan zijn de volgende vormen: boboko, hoofd, Mab. boko; angangi, kies, waarschijnlijk voor ngangangi, vgl. Bar. njangi, kauwen, en bagangi, kies, Mak. ngangalas, kies, guguo, neus, Mab. guo; papleo, tong voor papaleo, stam paleo, Mab. pleo; kitkitam, oogharen; kakamo, arm, hand, Mab. komo; sasagou, baard, Mab. sagou; ngengeo, wang; liflifang, wenkbrauw; mirmaril, gal, Saw. marel bitter; pupuo, knie; tutumpo, hiel; pepeo, speeksel; sasuno, elleboog ; giglo, oksel, voor gigilo; tatmān, schouderblad, voor tatamān; papapo, voetzool, stam pāp, beneden, onder pitpitas, kuit; laf-laf, bloed.

19) $Z$ ie verder Hoofdstuk IV van de Vormleer. 
daus tja loló, Adam en Eva woonden in het Paradijs; dòròram( $\breve{e})$

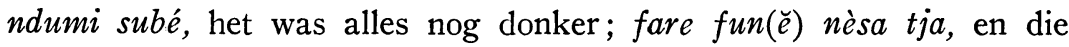
andere hond.

In grondwoorden komen combinaties van nasaal met homorgane oraal niet voor. Bij ontlening worden dergelijke combinaties tot de orale consonant gereduceerd, bijv. kabil, geit $=$ Mal. kambing; tabaga, rood koper $=$ Mal. tembaga; rate, ketting $=$ Mal. rantai. Sommige woorden die een dergelijke combinaite van consonanten zelf niet hebben, worden overgenomen met een dergelijke consonant-combinatie, bijv. Mal. kelakuan - Bul. kalangkuan, gedrag; Mal. roda - Bul. ronda, wiel, schroef v. e. schip; Ned. ketel - Bul. kentel, ketel.

Wel kan een nasaal gevolgd worden door een homorgane orale consonant op de grens van een prefix en een grondwoord, bijv. mpun, gij doodt, van $m$, pronominaal prefix v.d. 2 de pers. ev. en pun, doden; ndor, hij, zij verzoekt, van $n$, pronominaal prefix v.d. 3 de pers. ev. en dor, verzoeken; ntota, hij, zij hakt, van $n$ en tota.

De combinaties van consonanten, die in grondwoorden kunnen voorkomen, zijn enkele combinaties van $s$ met volgende consonant, bijv. smo, mond, tand, en van een consonant gevolgd door een liquida, bijv. plu, lichaamshaar, veer.

Op de grens van grondwoord en affix zijn tal van consonantopeenvolgingen mogelijk, bijv. fajatfo, met atap dekken, van jataf, dak; famautngo, weer met elkaar spreken, nadat men boos op elkaar is geweest, van mauting, spreken; nlit, hij, het kleeft, van lit, kleven en het pronominale prefix $n$; nderer, hij, zij volgt, van derer, volgen; fautno, manen, van utan, fautan, vragen; mdalim, scherp, van dalim $+m$; mfànas, van fànas $+m$; oplu, overmorgen, optjol, over drie nachten, opfat, over vier nachten; popluai, eergisteren, poptjòlai, eergisteren, van de grondw. $l u$, twee en $t o l$, drie, met voorgevoegd $p o p$ en achter gevoegd $a i$.

De pronominale prefixen welke uit een enkele consonant bestaan, indien ze gevoegd worden voor een grondwoord, dat begint met een vocaal, $w$ of $j$, krijgen een pěpět-achtige voorslag, indien zij gecombineerd worden met grondwoorden welke beginnen met een consonant, bijv. ěnmaralapsis, ěttotoláng, ěnfarero, ěkfaungo, ĕdfanas, ětlonga. Er lijkt dan een lettergreep-grens aanwezig te zijn tussen beide consonanten. Deze voorslag zal in de spelling niet weer gegeven worden. Indien aan deze vormen met pron. prefix een ander woord voorafgaat (wat in de practijk zeer vaak het geval zal zijn), dan wordt de 
consonant van het pron. prefix met dit voorafgaande woord verbonden en wordt er geen voorslag gehoord.

Verder doen zich nog de volgende verschijnselen voor op de grens van affix en grondwoord en bij sommige gevallen van reduplicatie:

1. Bij aanhechting van een possessief suffix achter grondwoorden eindigend op een gerekte $a$ of $o$ of op de variant van $a$ of $o$ die gelijkt op de vocalen van resp. Ned. kaas en koos, treedt de variant van deze vocalen op welke gewoonlijk staat in gesloten syllaben, bijv. van fia, dijbeen, jafiàk, mijn dijbeen; van boboko, hoofd, jabobokòk, mijn hoofd, abobokòm, uw hoofd; itebobokòr, onze hoofden; van tolo, ei, jatolòk, mijn ei. Een gerekte $e$ blijft gehandhaafd, naar reeds eerder is opgemerkt.

2. Soms gaat een $g$ over in $k$, bijv. van igas, zich verhovaardigen, faiksa, zich op iets verheffen.

3. Indien een grondwoord beginnend met een $t$, gecombineerd wordt met een prefix $f a$ - of $a f-$, dan wordt soms deze begin- $t$ genasaleerd, bijv. van tet, vlonder, afnet, over een vlonder lopen; van tam, fanam, urine, en fanami, urineren (Waigeo en Gebe tami, urine, urineren).

4. Indien een grondwoord beginnend met een $d$ gecombineerd wordt met het prefix $f a$-, gaat de begin $d$ over in $r$, bijv. van $d o m$, drinken, farom, drenken; van dumi, alle, alles, farumi, allemaal. Ook bij reduplicatie gaat de $d$ over in $r$, bijv. van diring, omwanden, diriring, wand; van dor, verzoeken, dòror, verzoek; van dòram, donker, dòròram, duisternis.

3. Indien een grondwoord beginnend met een $t$, gecombineerd wordt met de pronominale prefixen $t, d$ en $n$, gaat deze begin $s$ over in $t j$,

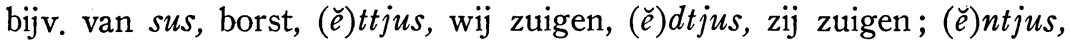

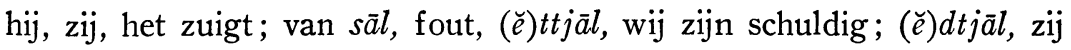

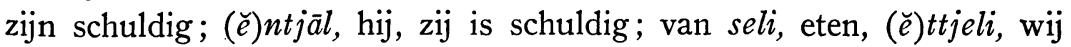

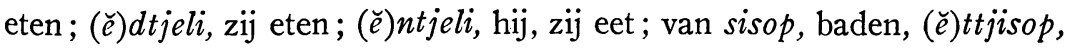

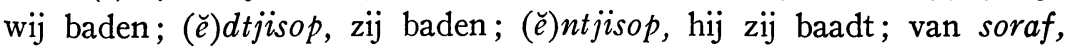

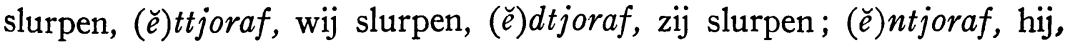
zij slurpt.

Ook in andere gevallen gaat $s$ over in $t j$ op de grens van twee woorddelen, bijv. van lalan, duizendtal, en $s a$ één, lalantja, één duizend; van man, mens, en si, zijlieden, mantji, de mensen; van lalaman, wachten, en $s u$, eerst, lalamantju, wacht eerst. Ook voor $l$ gaat de $s$ soms over in $t j$, bijv. van $d e l$, volgen, en $s i$, zijlieden, deltji, makkers, volgelingen; 
van tazeri, binden, en sa, een, tazeiltja, een bindsel, tiental v. prauwen; van tulis, schrijven en $e$, met, tultje, schrijven met; van tanat, tiental vademen, en $s a$, een, tanattja, een tiental vademen.

6. $T$ wordt soms $t j$ voor $i$ en in het grondwoord $t o l$, drie, bijv. van $p \bar{a} t$, steen, en $\bar{\imath}$, slijpen, pātjī, slijpsteen; van fai en tol, faitjol, driemaal; $a i$, hulptelwoord + tol, aitjol, drie stuks $\left.{ }^{20}\right)$; optjol, naast optol, drie nachten; poptjolai, drie nachten geleden, eer-gisteren ${ }^{21}$ ).

Do) Dr. Esser meent onder invloed van $i$; in het Mab. en Pat. heeft men aitjel.

21) Dr. Esser wees mij op Mor. itolu, drie nachten, zie Klank- en Vormleer van het Morisch, 2de d1. p. 280-281, Verh. Kon. Bat. Gen. dl. 67, 4 (1933); hij meent dat de $i$ van plaats veranderd is. 


\section{VORMLEER.}

\section{HOOFDSTUK I.}

Het zelfstandig naamoord.

\section{Grondwoorden.}

De meeste substantiva zijn grondwoorden, bijv. $u$, s.v. rotan; $m t \bar{a}$, oog ; fen, schildpad ; fun, hond ; luf, muis ; ebai, huis ; ulan, pot ; lolas, berg; làtan, wind; ai, hout; waga, cocos. Als secundaire grondwoorden kan men beschouwen de woorden, die duidelijk reduplicatie of geminatie vertonen, doch die in hun kortere vorm thans niet meer voorkomen, bijv. kakamo, hand, arm; guguo, neus; loblob, vlam; boboko, hoofd; gugulát, worm; gigiáp, as ; gigagap, klapperrat, eekhoorn; benga-benga, s.v. schelpdier, nautilus; dabudabu, s.v. groente; dingding, kinderliedje; dongdong, borstbeen.

Vele werkwoorden worden zonder enige verandering ook als substantief gebruikt, b.v. ān, eten en voedsel, spijs; sus, zuigen en borst, mammae; tub, leven en het leven; sagige, zweten en zweet; sadaka, aalmoezen geven en aalmoes; $n u f$, wasemen van water en wasem; nafsu, begeren en begeerte; loblob, vlammen en vlam; pake, kleden en kleding; ulan, regenen en regen; lèfo, schrijven en schrift; mafngel, dromen en droom; $\grave{o}$, vloeistof doorslikken en teug, slok.

Ook enkele adjectieven worden zonder toevoeging van enig affix als subst. gebruikt, bijv. mumuang, leeg en luchtruim; mufuf, fijn en het fijne, de bloem van iets, essence.

2. Grondwoorden + reduplicatie of geminatie.

1. Benamingen van werktuigen gevormd door reduplicatie of geminatie van werkwoorden, bijv. pitpitan, bindsel, van pitan, binden; leslèsan, bezem, van lèsan, vegen; pupukal, prop, stop, van pukai, sluiten; pelpèlet, schaamgordel, van pèlet; tjutjut, rijststamper, van $t j u t$, stampen; sisele, roeispaan, schepper, van sali, roeien, scheppen; arara, beitel, van ara, beitelen; teteta, sagoezeefje, van teta, zeven; tjutjulak, stok om vruchten af te stoten, van tjulak, stoten met een stok; ngisngis, maat, van ngis, meten; ifif, onderlaag, van if, iets ergens onderleggen ; tultud, angel van een vis, van $t u l$, steken v.e. vis; $e p e p$, takken cnz. die 
men om een cocosboom bindt om te beletten, dat men er in klimt van $e p$, een cocosboom aldus omwinden; titipal, oversteek, pas, korte weg van tipal, afsnijden; sisei, haarkam van sai, het haar kammen.

2. Door reduplicatie of geminatie van werkwoorden worden ook gevormd zelfst. naamw., die de handeling zelve of het resultaat of het object van de handeling of werking in het werkwoord genoemd, uitdrukken, bijv. palpalas, betaling, van palas, betalen; dòror, verzoek, van dor, verzoeken; maumauting, woord, van mauting, spreken; mamängi, geroezemoes, van māngi, drukte maken; lololai, haarwervel, draaikolk, van lolai, omkeren; opopi, pak, van opi, inpakken; diriring, wand, van diring, omwanden; tibtibil, las, verbinding, van tibil, lassen, verbinden; ututa, gedachte, van uta, denken; ututan, vraag, van utan, vragen; ununaf, schub, van unaf, ontschubben; tailtail, lof, van tail, prijzen, loven; peipei, daad, van pei, doen; maimai, schaamte, schaamdeel, van mai, zich schamen.

Ook van adjectieven vormt men aldus zelfst. naamw., bijv. pispisi, pijn, ziekte, van pisi, pijn hebben, ziek zijn; māngmāng, het droge, van māng, droog; matmat, de dode, hetgeen dood is, van mat, dood, sterven; mismis, het zoete, zoetigheid, van mis, zoet; tèbtèb, zwaarte, gewicht van tèb, zwaar ${ }^{22}$ ).

\section{Grondwoorden + bepaalde affixen.}

1. Nomina actoris vormt men regelmatig van werkwoorden en adjectieven door voorvoeging van $m a{ }^{-23}$ ), bijv. mamauting, veelprater, van mauting, spreken, praten; madom, zuiper, zuiplap, van dom, drinken; mapia, wegloper, van pia, weglopen; mafasula, gebieder, van fasula, bevelen geven; mabusu, luiaard, van busu, lui ; matotolē, nijdigaard, van totolè, tolē, boos ; mabibisil, hongerlijder, van bibisil, hongerig ; matuli, slaapkop, van tuli, slapen; mador, vraagal, van dor, vragen, verzoeken; maai, rover, van $a i$, roven.

2. Door het prefix $f a$ - worden substantieven gevormd, die de plaats aanduiden, waar iets geschiedt of zich bevindt, soms met het suffix $o$ nog daarbij, of enkel door dit laatste, bijv. fatino, weefgetouw, van tino, weven; faraftibo, onderste wandbalk, waarin de gabba-gabba-wand wordt geslagen, van daftib, inslaan; fafahleo, rugleuning, standaard,

22) Volgens mededeling van de heer M. J. Gouweloos komt deze betekenis van de woordherhaling in het Lakisch (Z.O. Celebes) veel voor. Men heeft daar bijv. momorvila, hetgeen wit is, van morvila, wit; matemate, hetgeen dood is, van mate, dood enz.

${ }^{23}$ ) Zie N. Adriani, De Barese sprekende Toradja's dl. III, p. 325-326. 
ezel, van fahle, leunen tegen; sapngo, uitgang, monding (bijv. waja sapngo, riviermonding; botol sapngo, opening, mond v.e. fles; barea sapngo, deuropening), van sapang, er uit, naar buiten komen; modtjo, uitgang, uiteinde, van amorit, afgebroken; tubo, uitspruitsel, van $t u b$, leven ${ }^{24}$ ).

Ook collectieven worden door $f a$ en $o(u)$ gevormd, bijv. fatenou, gebroeders van teno, broeder; faramau, gezusters van rama, zuster; misschien ook fatareu, bigamie, van $\operatorname{tare}($ ?).

3. Men treft ook substantieven aan gevormd met $f a$, die zich moeilijk laten verklaren. Volgens Dr Esser heeft men hier wellicht te doen met wat Prof. v. Ronkel ,praeformantia” genoemd heeft ${ }^{25}$ ).

Voorbeelden zijn: famule, achtersteven, van mul, achter, vgl. Waigeo mul, achterste delen; Bar. muli, Nap. mule ${ }^{26}$ ); fatiwa, plant, van tizwa, planten; fafual, vogelnest, stam fual, vgl. Saw. ful, vogelnest; falogi, klein huisje voor sagoekloppers, van logi; fafajäl, voorteken, stam $j \bar{a} l$, nemen, halen, vgl. Geb. $j \bar{a} l$, voorteken; Saw. fafejalo, id.; Mab. fafialo, id.; Pat. fafajāl, id.; falai, zeil, stam lai, vgl. Mal. lajar; Saw. loje; fapaluan, het midden, stam palu, vgl. Makj. palo, half; Waigeo kapalo, de helft, het midden, Pat. pala, id.; Saw. fepelun, id.; fanam, urine, stam nam, tam, Waigeo tami, urine; Geb. tami, urineren ${ }^{27}$ ).

4. Door het voorvoegsel $t a$-, dat veelal de functie vervult van het

24) Vgl. Mal. tumbuh, Bar. en Mor. tuzen, leven, uitspruitsel.

25) Klank- en Vormleer v. h. Morisch II \& 293, p. 293, 294.

26) $\mathrm{Zie} H$. Kern, De Fidjitaal, enz. p. 155 en 156, en G. W. W. C. Baron v. Hoëvell, Iets over de vijf voornaamste dialecten der Ambonse landstaal, p. 41.

$\left.{ }^{27}\right)$ Volgens N. Adriani (De Barese sprekende Toradja's, dl. III, p. 326) komt in het Bulisch ook een prefix $k a$ - voor. Hij geeft daarvan een drietal voorbeelden: kapilelu, met vele krommingen, kaptjut, dik van stoffen of lijnwaden en kalulu, verbindingsstuk tussen kiel en boorden van een prauw, vgl. lu, kiel. Het zou dus zowel bij substantieven als bij adjectieven worden aangetroffen.

Het is evenwel de vraag, of dit prefix wel Bulisch is. Wanneer wij bovengenoemde woorden vergelijken met hun equivalenten in andere talen van $Z$. Halmahera dan vinden wij in het Gebe kabejeli, krom; Saw. kebile, id.; Pat. kabaila, id.; Gebe kaptjit, dik; Pat. kiptjit, id.; Saw. bebtit, id.

In het Gebe komt wel een prefix $k a$ - veelvuldig voor, dat mogelijk tot de zgn. "praeformantia" moet gerekend worden, bijv. kafofo, wang; Saw. fofo ; Pat., Mab. id. : Makj., Gare hoho; kafia, dij; Bul. fia; kamou, stom Bul. mou-mou: kafani, vleermuis, kalong: Bul. fni; kapāt, steen; Pat. kipāt; Bul. pät; kamtu, sterk, hard: Bul. mtú.

Het woord kalulu schijnt van Noord-Halmahera afkomstig te zijn. Zie M. J. van Baarda, Galelareesche Woordenlijst, p. 96: o deru ma kalulu, en A. Hueting, Tobeloreesch Woordenboek, p. 270: o ngotiri ma kalulu, vgl. Saw. jel kelul; Waigeo wan alolu; Gebe wag kalulu. 
betrekkelijk vnw., vormt men substantieven, van substantieven, adjectieven, bijwoorden en werkwoorden, bijv. tadtubtub, die zij leven, de levenden; tadmat, die zij dood, de doden; ta ni ebai, die zijn huis, huisheer; smo pero tapuis, bovenlip; smo pero tapāp, onderlip.

Een ander $t a$, dat men voor subst. of adj. aantreft, komt mij voor enige overeenkomst te hebben met Sang. $t u^{\mathbf{2 8}}$ ) en $t a, k a^{29}$ ) en dus een honorifiek voorvoegsel te zijn, bijv. tawawai, de jongste, van wawai, kind, kleine; tauati ${ }^{30}$ ), de oudste van uat, echtgenoot, man, oud.

Men vindt dit prefix ook voor namen van enkele familiebetrekkingen, bijv. taifori (ta-ifo-ri), hun schoonbroeder; tarino (ta-ri-no), schoonzuster; tafalen, achterneef.

Naast $t a$ - komt ook voor het prefix $d a$-, bijv. dauahleo, de oude; dangolo, het oudje. Fare mān tja hmā re hnjē tasiá dauahleo re dangolo, en die man zijn vader en zijn moeder die waren een oud man (de oude) en een oude vrouw (het oudje). Waarschijnlijk is dit $d a$ te vergelijken met Bar. la en $r a^{31}$ ) en Mor. $d o$, $r o^{32}$ ), vgl. ook Mal. $d a^{33}$ ).

5. Men treft ook enkele zelfst. naamw. aan met het suffix $-t a$, dat wellicht als een soort lidwoord of nadrukswijzer achter de woorden te beschouwen is. Het ontvangt steeds de klemtoon. Voorbeelden zijn: uattá, de echtgenoot; ngolotá, de echtgenote; oloantá, het dorpshoofd; Ian-toatá, de afgod der Buliërs; gurutá, de onderwijzer; emtutá, de oom; eantá, het pleegkind.

Het dient ook om te personifiëren, bijv. gutá, de slang, luftá, de muis, ngangatá, de uil, vgl. Mal. si, Tobel. ma, Mak. $i$ of pung.

6. Verder vormt men door het suffix -o substantieven van adjectieven en werkwoorden, bijv. mamàglo, grootte, van mamàgal; msaio, breedte, van msai; mfàntjo, warmte, van fànas; lawo, verte van lau; mlamno, diepte, van laman; mlango, lengte, van lànga; tebtebo, zwaarte, van tebteb; re maimaio pa, zonder schaamte, van mai; re mtjaito pa, zonder vrees, van mtjait, vrezen; uhngo, gedaante, van using.

7. Misschien komen er ook nog substantieven voor, gevormd door

28) Zie N. Adriani, Sangireesche Spraakkunst, p. 137.

29) Zie N. Adriani, Spraakkunstige schets van de taal der Mentawei-eilanden, p. 86 en p. 52.

30) Het achtervoegsel $-i$ is mij hierin niet duidelijk. Misschien is het een onbep. voornaamwoord, zodat het zou kunnen betekenen: het is de jongste, het is de oudste.

31) N. Adriani, Spraakkunst der Barese-taal, p. 261.

3.2) S. J. Esser, Klank- en Vormleer v. h. Morisch, p. 66 en 67.

33) C. A. v. Ophuysen, Maleische Spraakkunst, 2de druk, p. 131. 
het suffix -an of $-a n g^{34}$ ), waarbij mogelijk in enkele gevallen ook 't prefix $f a-$ nog betekenis heeft. De enige gevallen zijn: failān, mast, vgl. Saw. filjān of felān; Mab. filān; Wed. feljong; Geb. faljain; Pat. felajan; Makj. halion; Nuf. Radj. Emp. faliana, mast; het Bulische woord is waarschijnlijk een omzetting van faljan, dat weder staat voor falajan, d.i. falai, zeil of Mal. lajar, Saw. loje, met -an, dus: plaats waar zich het zeil bevindt; fapaluan, midden, het midden, van palu; oloan, hoofdman, dorpshoofd, vgl. Wed., Pat., Geb., Mab., Saw. ulon, id., wellicht met an gevormd uit olo, dat niet in de taal voorkomt, maar identiek kan zijn met Indon. ulu, oorsprong, bron, hoofd; misilāng, gelijkenis, waarschijnlijk van Mal. misal ${ }^{35}$ ). In overgenomen woorden blijft het vaak of verandert het in -āng; bijv. kardjāng (Mal. kĕrdja, pěkěrdjaan), werk, arbeid; kajāng (Mal. kaja, kěkajaan), rijk, rijkdom; durakan (Mal. durhaka, kĕdurhakaan), misdaad; lamahan (Mal. lĕmah, kĕlěmahan), moe, vermoeidheid; subahan (stam?), zorgen, moeite, verleiding.

8. Woorden, die wij als werkwoorden aanzien, beschouwt men in het Bulisch vaak als naamwoorden ${ }^{36}$ ), bijv. ulo loló, houden van (ulo is identiek met Bar. puru, Sang. pulu, gewillig, genegen), en loló met Mal. dalam; ik houd er van = jaulok loló, mijn houden er van. Men verbindt ze dus met bezitt. vnw. en wel op dezelfde wijze als de namen van lichaamsdelen, enz.; smat ta gitjori gogō ulori loló ntamaga farwat, mensen, wier huid zwart is, hun houden er van, hij kauwt sirih; le, haat, haten; ik haat $=j a n i k l e$, mijn haat, enz. Dit is een uitzondering op de boven genoemde regel. ulo ja neto, in het binnenste is, zich herinneren, wordt jaulok ja neto $=\mathrm{ik}$ herinner mij, mijn mij herinneren; isa ulo ja neto ja pa, niemand zijn herinneren mij, niemand herinnert zich mij; aulom ja neto nim sāl fatutulinge na su, uw u herinneren uw eigen fouten eerst, herinner $\mathfrak{u}$ eerst uw eigen fouten; ulo ja mitji, iemand een kwaad hart toedragen, wordt siulori ja mitji, zij dragen een kwaad hart toe, hun een kwaad hart toedragen; jaito anim ali re bangsa siulori ja mitji ja, ik weet uw familie hun mij een kwaad hart

34) Zie N. Adriani, De Barese sprekende Toradja's, dl. III, p. 326-327.

35) Dr. Esser stelde de vraag, of dit niet in zijn geheel (met het suffix) een ontlening kon zijn.

36) Zie N. Adriani, De Barese sprekende Toradja's, dl. III, p. 322, 331, Spraakkunst de Barese taal, p. 447; R. Haaksma, Inleiding tot de studie der vervoegde vormen in de Indonesische talen, p. 155, 156, 168, en de bespreking hiervan door Esser in T.B.G. (1935), p. 330-331; zie ook Klank- en Vormleer v. h. Morisch, p. 230-232. 
toedragen, ik weet, dat uw familie mij 'n kwaad hart toedraagt. Het zijn dus meestal woorden, die gevoelens uitdrukken.

\section{Combinaties van grondwoorden.}

Twee substantieven, die met elkaar één begrip vormen, worden in het Bulisch soms door het voegwoord re, en, met elkaar verbonden. Voorbeelden zijn reeds eerder gegeven in de inleiding. Enige andere zijn nog: $h m \bar{a}$ re $h n j \bar{e}$, vader en moeder, ouders; danahleo re dangolo, oude man en vrouw, de oudjes; mān re maping, man en vrouw, echtelieden.

Andere typen van samenstelling zijn: $1^{\circ}$ beide grondwoorden zijn substantiva, $2^{\circ}$ een is een substantief, een is een adjectief, $3^{\circ}$ een is een substantief, een is een werkwoord, $4^{\circ}$ een is een substantief, een is een telwoord.

Voorbeelden van $1^{\circ}$ : ai ulū, boomblad, groente; ai pio, boomvruchten; tatale tolo, kippenei ; lukam pio, lansatvrucht ; olat làpo, zeerand, strand; lukam peo, lansatpit; mamajás gagau, rookplaats, schoorsteen; sousoal gagau, ankerplaats; pira gagau, sagoevorm; mani plu, vogelveer; zaoo $p u$, nekstam, hals; mani golo, vogelstaart; fnai pogo, bamboespruit; dube smo, dondersteen. Het bepaalde volgt dus het bepalende.

In de volgende gevallen echter volgt de bepaling het bepaalde: luf ebai, huismuis; egat waga, cocosolie; egat rakrak, aardolie, petroleum; mani ulan, regenvogel, zwaluw ; waja sungai, zijrivier; mtā popó. (oog, het bovenste), voorhoofd; wōl pāp, (zon, onder) dwergen, die de zon naar boven zouden rollen, kabouters; ai loló (hout, het binnenste) bos; lolas popó (berg, het bovenste) bergtop; waja popó (water, het bovenste), waterspiegel; ngalo papapo (kin, het onderste) onderkin; fitjo papapo, (voet, het onderste), voetzool; smat pnu loló, (mens, dorp, in) dorpeling.

Voorbeelden van $2^{\circ}$ : tatmū bubuláng (wit, lood), tin; boboko kòro, kroeskop; laling nenèna, kleine weg, paadje; pumlànga, s.v. bamboefluit, ook plaatsnaam v.e. gehucht op N.O. Halmahera; smat miskin, arme; smat kajāng, rijke; aiwani gogō, zwart dier, varken; aizwani mlànga, lang dier, hert; lobo mamàgal, grote vinger, duim; lobo kòrikòri, kleine vinger, pink; nus mamàgal, groot eiland, naam v.e. eiland in de Maba-rivier; tiwer guratji, goudgeld; uahleo, oude man, oude; ngololeo, oude vrouw, oudje; salo gogō, zwarte damar, s.v. damar; bala po, nieuwe onderdaan, vrijgelaten Papoese slaven.

Voorbeelden van $3^{\circ}: p \bar{a} t \quad j \bar{\imath}$ (steen, slijpen), slijpsteen; lobo sadat (vinger, sadat, de Moh. geloof sbelijdenis opzeggen) wijsvinger; tao òslo 
(rug, tegen iets aan staan), wervelkolom; smat tantjāl (mens, die hij fout), misdadiger, overtreder; kastèla òsal (mais, staan), mais; lampur totoláng (lamp, zitten), staande lamp; karapesa bujebuje (stoel, schommelen, wippen), wipstoel; lilifáng gagām (duizendpoot, fosforiseren), s.v. fosforiserende duizendpoot; waja bubil (water, opborrelen), een plaatsnaam; pāt tulis (steen, schrijven), lei ; dab olol (mat, oprollen), een oprolbare mat; lusing tamaga (stampblok, sirih-pinang pruimen), een toestelletje om sirih-pinang in fijn te stampen.

Voorbeelden van $4^{\circ}$ : sangfát (span, vier), vierspan, ook een s.v. pak sagoe; eritól, drie dwarsliggers v.e. prauw, ook de gordel van Orion; smat lāl (mensen, veel), menigte.

\section{Geslacht.}

De aanduiding van mannelijk en vrouwelijk geschiedt door achter het bepaalde te plaatsen de woorden: mān, man, mannelijk en maping, vrouw, vrouwelijk, bijv. kòro mān, slaaf ; wawai mān, jongen; ntu mān, zoon; bou mān, beer; wawai maping, meisje; ntu maping, dochter ; kòro maping, slavin; bou maping, zeug; balk mano, de mannetjesbalken, d.w.z. de lange, overlangse balken v.e. huis boven de wand; balk mapingo, de vrouwtjesbalken, d.w.z. de korte balken, die over de breedte v.h. huis liggen. Men spreekt ook van olat mān, mannelijke, mannetjeszee, en olat maping, vrouwelijke, vrouwtjes-zee; het eerste betekent een onstuimige, gevaarlijke zee en het laatste een rustige, kalme zee.

Speciale namen voor mannen en vrouwen komen wel voor, doch er zijn ook namen, die zowel door mannen als door vrouwen gedragen worden.

Voor echtgenoot gebruikt men uattá en voor echtgenote ngolotá; een oude vrouw is ngololeo, een oude man uahleo.

\section{Getal.}

In het Bulisch kent het substantief geen afzonderlijke vormen voor enkel- of meervoud. Alleen komt als een soort meervoudsvorm achter sommige zelfst. naamw. (bijv. volksnamen) het pers. vnw. v.d. 3de pers. meerv. si, zijlieden.

Voorbeelden zijn: Sarani, Christen, Saranisi, Christenen; Isilāng, Mohammedaan, Isilāngsi, Mohammedanen; hmā re hnjēsi, ouders; mān re mapingsi (man en vrouw zijl.), echtgenoten; del, makker, deltji ${ }^{37}$ ), makkers; kòro mān, slaaf, kòro māntji, slaven; kòro maping, slavin,

37) Over de overgang van $-s i$ in $-t j i$ na bepaalde consonanten is reeds gesproken. 
kòro mapingsi, slavinnen; ntu, kind, ntusi, kinderen; $k b u$, grootvader, kleinkind, kbusi, grootvaders, kleinkinderen; wossi, overgrootouders of achterkleinkinderen; tabausi, voorouders; fun, hond, funtji, honden; bati, vriend, batisi, vrienden ${ }^{38}$ ).

Heeft het subst. een bezittelijk vnw. achter zich, dan volgt si dit pron., bijv. jantuksi, mijn kinderen; hmamam re hnjēmamsi, onze (excl.) ouders; meu hnje meusi, uwe moeders; itehmār re hnjēsi, onze (incl.) ouders.

Wil men bepaald uitdrukken, dat meer dan één persoon of zaak bedoeld is, dan bezigt men daartoe de onbepaalde telwoorden: nafale, alle; dumi, farumi, alle; using lalo, velerlei; lāl, veel; sagala, (Mal. sĕgala) alle. Voorbeelden zijn: bo nafale smat farumi dderera, opdat alle mensen tezamen ze volgen; smat tadpisi farumi, alle mensen, die ziek zijn; pelang mereis ndumi, alle prauwen zijn vernield; eta lāl, vele messen; dae lalo, verlerlei wapens; smat pnu lalo, mensen uit allerlei dorpen.

Om het enkel- en meervoud v.e. substantief in de vocatief aan te duiden, plaatst men achter de woorden de pers. vnw. au, gij of meu, gijlieden, voorafgegaan door het betrekkelijke vnw. $t a$, die, bijv. smat tau! (mens, die gij), mens!; smat tameu! (mensen, die gijlieden) mensen!; bati tau! (vriend, die gij) vriend!; bati tameu (vrienden, die gijlieden), vrienden!; neka tau (jongere zuster, die gij), jongere zuster!; nòke tau (jongere broeder, die gij) jongere broeder!

Verder worden in de vocativus sommige woorden met de interjecties $-o,-k e$ of $-e$ gecombineerd, en wel op de volgende wijze: aja, moeder, aje, moedertje!; mama, vader, mamo, vader!; mamo ke, vadertje!; mame, vadertje!; uate, grootvader! oudje!; ngolo ke, grootmoeder!.

\section{Constructies met ni, na en $o$.}

Aan vele onzer prepositionele groepen van een substantief met voorafgaand van, beantwoordt in het Bulisch:

$1^{\circ}$ de constructie met $n i$, bijv.: guguo ni marapurus, neusgat (guguo, neus, en marapurus, gat); sapi na sus, uier van een koe (sapi, koe, en sus, uier, borst); boboko ni ubi, schedel (boboko, hoofd, en $u b i$, schaal v.e. cocosnoot); go ni long, stuit, been v.h. achterste (go, achterste, en long, been); lobo ni kolano, middelvinger, koning der vingers (lobo,

38) Zie verder N. Adriani, De Barese sprekende Toradja's, dl. III, p. 330, en F. J. F. van Hasselt, Nufoorsche Spraakkunst, p. 27. 
vinger, en kolano, koning); ai ni tipa, spruit v.e. boom (ai, boom, en tipa, uitspruitsel).

De volgorde is dus: $1^{\circ}$ het bepalende woord, $2^{\circ} n i$ of $n a, 3^{\circ}$ het bepaalde. $N i$ kan wel niet anders zijn dan het hierna nog te bespreken $n i$ of $n a$, dat met het pron. pers. v.d. 3de pers. enkelv. $i$ bij bepaalde groepen van woorden het bezitt. vnw. 3de pers. enkelv. vormt. In $a i n i$ tipa behoort het dus bij tipa, het bepaalde woord, dus ni tipa, zijn spruit; ai ni tipa, boom zijn spruit.

$2^{\circ}$ de constructie met $-o$, bijv.: fitjo papapo, voetzool; bou wàngto, varkensvlees; waga smàto, cocosstam; sapi wawaio, jong v.e. koe, kalf ; pupi aio, sagoeboom; waga aio, cocosboom; sus waio, melk, zog; fitjo fānfānjo, voet v.h. been; waja uluo, oorsprong der rivier.

Deze tweede constructie komt overeen met de eerste; de volgorde der woorden is dezelfde, doch in plaats van $n i$ of $n a$ vóór het bepaalde woord, vindt men $o$ er achtergevoegd. Waarschijnlijk is $o$ niet ten volle als pron. poss. 3de pers op te vatten, maar meer als lidwoord, vgl. balk $m \bar{a} n o$, de mannetjesbalk ( $m \bar{a} n$, man), d.i. lengtebalk v.d. bovenbouw v.e. huis ${ }^{39}$ ).

\section{Constructies met $-a,-0,-e,-e a$ en $-e o$.}

Aan vele andere van onze groepen van subst. + voorzetsel of van pron. met voorzetsel beantwoordt in het Bulisch de formatie met de suffixen $-a,-o,-e,-e a,-e o$ achter de werkwoorden ${ }^{40}$ ).

Voorbeelden zijn : jaifasawa au, ik trouw met je; jaigòno Demosaja, ik kocht van D.; ingòna ja ian, hij kocht vis voor mij ; intigea pāt, hij gooit met stenen; intigeo ja pāt, hij gooit naar mij met stenen; fare nopea pitpitan, vervolgens wikkelde hij het in een bindsel; jaikatjutje fitfok mali pät, ik stootte met mijn voet tegen een steen; ndòmo be ginini ulu, hij drinkt slechts uit een ginini-blad; luf tja ndòro matjan tja, de muis vroeg aan de tijger; jaikamtulo musalá, ik slaap op een slaapmat; fare nfatèlmo ni snapān tja bontapngo $i$, vervolgens richtte hij zijn geweer op hem willende op hem schieten; fare nfatnaze ntu tja, en hij beval aan zijn kind; ikem ntum tja jab isa nopea $i$, ik zag uw kind een arend vloog met hem; fare hmā ntolea $i$, en zijn vader was boos op hem; pelang tja jaitinaki bali, die prauw ik kalefater hem met werk; jai tjiboboi gulegule, ik eet rijstepap met een lepel.

39) Zie N. Adriani, De Barese sprekende Toradja's, dl. III, p. 307-308.

40) $\mathrm{Zie}$ hierover nader bij de behandeling der suffixen. Zie ook N. Adriani, o.c. p. 327 .

Verh. dl. X. 
HOOFDSTUK II.

Het bij voeglijk na m woord.

\section{Grondwoorden.}

Een aantal adjectieven zijn grondwoorden. $\mathrm{Zij}$ duiden vaak een lichaamsgebrek of een ongunstige eigenschap aan, bijv. pilok (Tobel. piloko), blind; biaf, blind; katjil, doof ; balang, lam; silek, scheel; umal, onhandig, dom ${ }^{41}$ ).

Samengestelde adjectieven zijn: gogó iaf, donkerbruin, bruin als de iaf, bruinvis; gogó un, gitzwart; gogó nbat, pikzwart; kakalā nbat, bloedrood; banban nbat, goudgeel (bat, sterk van kleur); bubuláng dadiá, spierwit; awal kakal, eeuwig; miskin re hal, arm.

\section{Grondwoorden met reduplicatie of geminatie.}

De meeste adjectieven zijn geredupliceerde of gegemineerde grondwoorden. Voorbeelden zijn : kakalä, rood; nenèna, klein; kikeu, gekruld; kokopē, kort, laag; mumuan, leeg; mumulák, jong; gaglī, mager; sisongit, nat, bebeb, plat; gagalúm, week; bibisil, hongerig; bubuláng, wit; kakanin, zuur; banban, geel; bisbis, blauw, groen; tebteb, zwaar; bakbak, vol; bofbof, zwaarlijvig; gelgel, bont; kòrikòri, klein; gogó, zwart.

Soms staat naast de niet geredupliceerde vorm een geredupliceerde, welke betekent, dat de eigenschap in meerdere of in mindere mate aanwezig is, bijv. fànas, warm, fifànas, lauw ; djakam, beurs, verrot; djikdjakam, onvolkomen, bedorven. Ook heeft soms, zoals al uit de gegeven voorbeelden bleek, klankwisseling ${ }^{42}$ ) plaats, zo ook: sisongit, nat; kikeu, gekruld; ngingai, bitter; tjitjapal, dubbel, v. e. banaan, twee bananen in één schil; tjitjokan, geil, wellustig; tjitjoal, hard, sterk.

Het komt voor, dat door herhaling adjectieven worden gevormd van grondwoorden met substantivische betekenis, bijv. mamàgal, groot, van màgal, grote tak v. e. boom (vgl. màglo, grote tak er van, schouder); wairwaja, waterachtige rijstepap; wōlwoōl, zonnig, van wōl, zon; musim wōlwōl, zonnige, droge moeson).

41) Vgl. N. Adriani, Spraakkunst der Barese-taal, p. 193 en 427.

42) Klankwisseling komt eveneens voor bij sommige substantieven, telwoorden en werkwoorden, bijv. gigoap, made, wormpje; gigagap, klapperrat; gigemin, s.v. sagoepalm; tjitjepi, waterschepper; sisei, haarkam (sai, het haar kammen); sisop, baden (Saw. sep); sisele, schepriem (saldi, roeien met een schepriem). 


\section{Grondwoorden met een affix.}

De adjectieven, die niet door reduplicatie of geminatie zijn gevormd, verkrijgen veelal het prefix $m a$ - of $a m$-, ook wel verkort tot $m$-. Krijgt het adjectief een pers. vnw. voor gevoegd, dan heeft het prefix de vorm -am.

Voorbeelden zijn: mfànas, heet, warm (Bar. mapane, Mal. panas), stam fànas; mafia, goed, mooi (Sang. mapia van pia), stam fia; mlifis, dun (Bar. manipi, Mal. nipis), stam lifis; maòf, mak, tam, stam òf; mlànga, lang, hoog, stam lànga; ndàlim, scherp (Bar. matadja; Boeg. tarēng), stam dalim; mlaman, diep (Mal. dalam, dolong), stam laman; msai, breed, stam sai; amgai, moe, stam gai; majai, slecht, stam jai; $m n \bar{a}$, lekker, zoet, stam nā; majana, licht, niet zwaar, stam jana; mtu, vast, sterk, stam $t u$; marara, wild, stam rara; maping, vrouwelijk, stam ping (Nuf. bin, Mab. mpin, Mal. bini, Mak. baine, Sang. bawine, Nap. rawine).

Fare tēt tja namsai pa, en dat brugje was niet breed; waja tja namfànas $t u$, dat water was zeer warm; eta tja namdàlim pa, dat mes is niet scherp; fofo tja namdjakam( $\breve{e})$ tò, die citroen is al verrot; fafan tja namlifis, die plank is dun.

De adjectieven met het prefix ma- of $m$ - kunnen optreden als secundaire grondwoorden, bijv. mafia, goed, famafia, goedmaken; zo ook famajai, bederven, slecht maken; famaòf, temmen, van maòf, tam; famlànga, verlegen, van lànga, lang; famajeu, zich beijveren, van majeu, ijverig.

Dit $m a$-, waarvan $a m$ - en $m$ - de varianten zijn, is in de Indonesische talen het gewone prefix van het intransitief-passief en van de met het intransitief-passief gelijkstaande adjectieven.

$M a$ - voor werkw.stammen heeft de betekenis van ons verleden deelwoord; deze woorden vertonen in het gebruik veel overeenkomst met adjectieven. Voorbeelden zijn: amjaling, weggedreven, van jaling, wegdrijven; amjangis, verdwenen; mgoi, gebroken, geknakt; msake, gestrooid, gezaaid ; mgini, verbrand; amewis, vergaan, gestrand; amtòtò, gereed; amop, omgevallen; amorit, afgebroken.

Popei amenimam pelang tja namjaling, gisterenavond is onze prauw

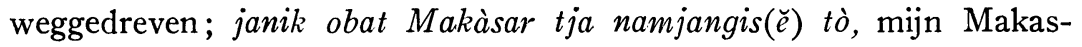
saarse sarong is al verdwenen; amenimam djara tja fitjo namgoi, een poot van ons paard is gebroken; itetamtòtò tò, wij (incl.) zijn al gereed; salili tja nfakiko nata saopat tja, fare hnjao tja namorit, de rode boommier snoerde zich de buikband sterk om, vervolgens zijn buik was 
afgebroken; wakòtjé baki ikamop, het scheelde maar weinig of ik was omgevallen.

Van gelijke betekenis als het prefix ma- (am-, m-) is soms het prefix a-, bijv. las, nabij, alas, nabij zijn; lau, ver, alau, ver zijn; pelang tja nalas( $\breve{e})$ tò, die prauw is al dichtbij; pelang tja nalau subé, die prauw is nog ver; biaf, blind; abiaf, blind zijn; smat ta nabiaf tja, de mens, die blind is ${ }^{43}$ ).

In enkele gevallen vormt men adjectieven van werkwoordstammen met het suffix -o, bijv. èmo, zien er van, zichtbaar; nga tja èmo mnu $p a$, de maan is niet lang zichtbaar; loblob mamàgal èmo, grote vlammen waren zichtbaar; longlòngo (van lònga, horen), hoorbaar.

\section{Predicatief gebruik.}

$\mathrm{Bij}$ predicatief gebruik worden de adjectieven als werkwoorden behandeld. Voorbeelden zijn, behalve de reeds gegevene: inmamàgal( $\breve{e})$ tò, hij is al groot; ian tja nbili tò, die vis is al zacht (bedorven); jafi tja nbubuláng, dat krijt is wit; gabe namlànga tu, namgoi, indien het zeer lang is, het is gebroken; wōl tja renta npopolulu be, de zon is enkel maar rond; dtofu ta namlànga, bo nfamlàngo re ta kokope, zij hopen op hetgeen hoog is, opdat even hoog zij hetgeen laag is (d.w.z. zij doen monnikenwerk).

Dit geschiedt echter niet als achter het substantief het aanw. vnw. tiná of $n a$ geplaatst is; ook niet na het woordje $j a$. Voorbeelden zijn: zè̀ma plu tiná gogó tu fare sasaletam, de veren van de jaarvogel zijn zeer zwart en glinsterend; mān na ulori na tjitjoal re mtu, de mannen hun gemoed is sterk en hard; gu ni mau-mauting na molang, de woorden van de slang zijn waar; fare pado na bersi, en de melaatsheid was schoon (weg); mna be gitjo na, lekker ook was zijn huid; riri karung tiná majana paube, hun zakken waren nog niet licht; puruparak gitjo na gangana, de huid van de boomkikvors is ruw; smat tiná majeu tu, die mensen zijn zeer ijverig; ai susus tja pan ja mafia, de geur van het susus-hout is lekker; maping tja ni akin ja molang, die vrouw haar inborst is oprecht; kamasefa isa glao ja māng, een kamasefa (s.v. papagaai) zijn keel was droog (had dorst); lèfo na majai, het schrift is slecht; janik eta manéna na pungpung( $\breve{e})$ tò, mijn mes is al bot; fare eta nenéna na mdalim $t u$, vervolgens het mes was zeer scherp; imtá na sasaletam laisawa intang, zijn ogen glinsterden als diamanten.

43) Vgl. N. Adriani, Spraakkunstige schets v. d. taal der Mentawei-eilanden, p. 49. 


\section{Attributief gebruik.}

Bij attributief gebruik plaatst men het adjectief eenvoudig achter het substantief. Voorbeelden zijn : ebai po, een nieuw huis; nòni Buli bubuláng, de blanke Bulische jongejuffrouw; smat sarani, een Christen; smat biaf, een blinde; smat Buli, een Buliër; smat Walanda, een Hollander; fafan gogó, een zwarte plank; ebai mlànga, een hoog huis; aiwani gogó, een zwart dier, varken; waja sino, warm water; gagau awal kakal, de eeuwige plaats, hemel; bala po, nieuwe onderdaan (de Papua's te Patani worden zo genoemd, de vrijgelaten slaven); kati madarawa, een valse unster; mtā gagám, glinsterende ogen; uta kikeu, gekruld haar; lawe pako, grof garen; lobo kòrikòri, kleine vinger, pink; pāt tulis po, een nieuwe lei; obat Makàsar, een Makassaarse sarong; padji Walanda, de Hollandse vlag; tinta gogó, zwarte inkt; djame ngengai, een bittere smaak; sbak besi, ijzerdraad; ulan rakrak, een aarden pot; ulan besi, een ijzeren pot; tiwor salaka, zilvergeld; tiwi kartas, papieren geld; tiwi guratji, goudgeld; rate guratji, een gouden ketting.

Als twee adjectieven bij hetzelfde subst. gebruikt worden volgen deze op elkaar verbonden door het voegwoord fare of $r e$, en, bijv. guru ni ebai tja mafia fare mamagal tu, het huis van de onderwijzer is mooi en groot; gagau ta mafia re bersi, een plaats, die mooi is en schoon; animam kabil ni sasagou mlànga; ni tado mlànga re kapilelu, onze geit haar (heeft een) lange sik; haar (ze heeft) lange en kromme horens; smat Walanda ddom te, smat Malaju ulori loló be ddom kofi, Hollanders drinken thee, Maleiers houden er van zij drinken maar koffie; silali doudou mlànga, zij daarheen de lange brug, zij gaan naar de lange brug; wàma ni warana bubuláng nut banban, mai pao kakalā, de jaarvogel zijn witte kleur brengt geel, maar de helft rood, de jaarvogel heeft een witte kleur met geel, maar een deel is rood; Masofo hnjē $m t \bar{a}$ pao biaf, Masofo's moeder haar ene oog is blind; mali rakrak patpatang smat npei rame mamàgal, op het vlakke veld maakt men een groot feest; janik ebai nenène, oloan tja ni ebai mamàgal, mijn kleine huis, het dorpshoofd zijn grote huis; tuang mamàgal ni ebai, de grote heer zijn huis.

\section{Zelfstandig gebruik.}

De adjectieven worden ook wel zelfstandig gebruikt en krijgen dan de betekenis van substantieven, bijv. ai ta nfasonjata mafia re majai, de boom, die openbaarde goed en kwaad; mtō mbalas nik mafia pa?, weet gij niet gij vergeldt (te vergelden) mijn goed(heid)?; jaboitofnga 
wala tja ni $m t u$, ik wil proberen het touw zijn sterk(te); $m t \bar{a} n i$ bubuláng, het wit van het oog; kakala tja ipuis, het rood het is boven; bisbis tja ipa $\bar{p}$, het blaww het is beneden; wahle jàfatol nenèna re mamàgal, wellicht dertig klein en groot; karung isizui ni tebteb tiná nfaitetai, negen zakken hun zwaar(te) was gelijk; osetane sidduk mafia, zekerlijk zij verkrijgen het goede ${ }^{44}$ ).

\section{Trappen van vergelijking.}

Wordt aan twee zaken een eigenschap in gelijke mate toegekend, in welk geval wij vaak in het Nederlands constructies met even gebruiken, dan wordt dit op verschillende wijze tot uitdrukking gebracht.

1. Door de reciproque vorm, die gevormd wordt door het prefix $f a$ en het suffix $-o$, bijv. mamàgal, groot, famamàglo, met elkander groot zijn; lobo na dfamlàngoi ${ }^{45}$ ) pa, de vingers zijn niet even lang; failān ailú tasiá dfamlàngo, die twee (beide) masten zijn even hoog; pelang salú tasiá dfamamàglo, die beide prauwen zijn even groot.

2. Door het adjectief al of niet voorzien van het suffix $-o$, gevolgd door de vervoegde vorm van het woord faitetai, aan elkaar gelijk zijn, op elkaar gelijken; bijv. pelang salu tasiá mamàglo nfaitetai, die beide prauwen haar grootte is gelijk; fafan kaslu tiná msaio nfaitetai, die twee planken haar breedte is gelijk; karung isizer ni tebteb tiná nfaitetai, die negen zakken hun zwaarte was gelijk, waren even zwaar; men kan ook zeggen: karung isiwi tiná tebtebo nfaitetai.

3. Door het adjectief te gebruiken gevolgd door het woord laisawa, als, gelijk, bijv. smat taie mlàngo laisawa smat tja, deze man zijn lengte is gelijk aan die man, deze man is even lang als die man; fafan taie msaio laisawa fafan tja, deze plank haar breedte is gelijk aan die plank; ikèm mani isa paube, ta plu ja bubuláng re sasaletam laisawa au taine, ik heb nog geen vogel gezien, wiens veren wit waren en glinsterden als deze gij (de uwe); sumu taie mlamno laisawa sumu tja, deze put zijn diepte is gelijk aan die put.

Bezitten de vergeleken personen of zaken de hoedanigheid in verschillende graad, dan wordt dit op de volgende wijze uitgedrukt: pelang taie, mamàgal be pelang tja, deze prauw, groot slechts die prauw, die prauw is groter dan deze prauw ; Kore ni ebai, mamàgal be tuang $(\breve{e}) \mathrm{ni}$ $e b a i$, Kore's huis, groot slechts toean's huis, mijnheers huis is groter

44) Vg1. Klank- en Vormleer v. h. Morisch, dl. II, p. 230.

45) Het element $-i$ aan het einde van famlàngo is mij niet duidelijk. In andere voorbeelden komt het niet voor. 
dan Kore's huis; ini sewa tja, mamàgal be ni baladja, zijn loon, groot ook zijn uitgaven, zijn uitgaven zijn groter dan zijn loon; ni del tasiá, pande be $i$, die zijn makkers slim ook hij, hij is slimmer dan zijn makkers; osetane kolano na, kajāng be ja, zekerlijk de koning, rijk slechts ik, ik ben zeker rijker dan de koning.

Een andere wijze is deze: Djou Lahatala ntjoba si mali parakara pusa ta nèsa fawe, ta ntebteb fawe mali parakara tantuba na, de Here God beproefde hen in een zaak, die weer anders was en die weer zwaar(der) was dan de vroegere zaak; mai pusa tja ntebteb fawe, maar dat ene het was weer zwaar (zwaarder); jaikututa taine jainenèna leo mali gadja tja $p a$, ik meen ik ben niet geringer dan die olifant.

Soms bezigt men ook wel het Ternataanse woord foloi, meer, zeer, bijv. Maban siddarān na foloi, de Mabarezen zijn zeer onbeschoft (meer dan anderen); waja na mairing nfoloi pa, het water is niet erg koud (niet meer dan gewoon).

De superlativus en de elativus worden uitgedrukt door middel van de woordjes $t u$, zeer, buitengemeen, en $l e o$, zeer. Het verschil van $t u$ en leo ligt hierin, dat men $t u$ bezigt bij woorden die iets groots, en leo bij die welke iets kleins of gerings aanduiden, bijv. inpa karung ta ntebteb tu tja, hij droeg de zak, die het zwaarste was; sumu tja namlaman $t u$, die put is zeer diep; anim eta tja nnenèna leo, uw mes is zeer klein; mamàgal $t u$, zeer groot; laoe $t u$, zeer ver; ntu tja npande $t u$, zijn kind is zeer knap; kòrikòri leo, zeer klein.

Men vindt ook zinnen als: animam susa tja tui pantu, ons verdriet, onze moeilijkheden, wij zeggen het niet meer (d.w.z. ze zijn onuitsprekelijk groot). Voorts bezigt men ook het woord nèsa, anders, bijv. tortor taie mafia nèsai, deze kapel is anders mooi, d.i. buitengewoon mooi ; lilit mumulák tja nkakanín nèsai, de jonge mangga is buitengewoon zuur. Ook het bijwoord famafia, mooi, buitengewoon, gebruikt men om de excessivus en de superlativus aan te duiden, bijv. npande famafia, hij is buitengewoon knap; wōl takapó famafia, de allereerste dag.

Ten slotte komt nog voor herhaling van het adjectief met tussenvoeging van het woordje ta, bijv. majai ta majai, het allerslechtste; tiná majai ta majai, dat is het allerslechtste, terwijl men de hoogste graad van kleuren uitdrukt door achtervoeging van de woorden dadia, un of bat, bijv. bubuláng dadiā, spierwit, doodsbleek; kakalā nbat, bloedrood; gogó un, gitzwart. 
HOOFDSTUK III.

H e t t e 1 w o or d.

\section{Hoofdtelwoorden.}

De hoofdtelwoorden van één tot tien zijn $s a$, één; $l u$, twee; tol, drie; fat, vier ; lim, vijf ; wònam, zes ; fit, zeven; wai, acht; siwi, negen. De tientallen worden gevormd met jàfa, dus jàfasá, tien; jàfalú, twintig ; jàfafit, zeventig; jàfasiwi, negentig enz.

Voor sommige voorwerpen heeft men evenwel een ander woord voor tiental ${ }^{46}$ ), nl. tanatjá, tien vadem; tanatlú, twintig vadem, enz.; flòtantjá, tien stuks, bijv. palen, bamboe, enz.; flòtanlím, 50 stuks, enz.; tawiltjá, tien stuks prauwen (letterlijk: een bindsel prauwen, zoals die vroeger als schatting moesten worden opgebracht aan de Sultan van Tidore); tawilfít, zeventig stuks prauwen, enz.

Honderdtal is slubi, dus slubisá, honderd; slubilú, twee honderd; slubisiwi, negen honderd, enz.

Duizendtal is lalan, dus: lalantjá, 1000; lalantjol, 3000; lalanfát, 4000 ; lalansizer, 9000 , enz.

Tien duizend is laksa (uit het Mal.); men zegt dan evenwel : laksa báhnga, 10.000 éénmaal ; laksa failú, 10.000 tweemaal $=20.000 \mathrm{enz}$.

Uit het Mal. heeft men ook juta, millioen, overgenomen, dat men evenals laksa behandelt: juta bàhnga, millioen éénmaal $=1.000 .000$; juta faifát, millioen viermaal $=4.000 .000$; enz. ${ }^{47}$ ).

De samenstelling van getallen geschiedt door achter-elkander-stelling en verbinding met het voegwoord $r e$, en, bijv. jàfasá re isa, een tiental en één, elf; jàfasizer re isizri, 99, enz. Tanattjá re lofsá, tien vadem en een, 11 vadem; flòtantjá re ailím, tien stuks en vijf stuks, 15 stuks; flòtanlim re ailú, 50 stuks en twee stuks, 52 stuks; pelang tawiltjá re satól, tien stuks prauwen en drie stuks prauwen, 13 prauwen; slubisá re jàfalú re silím, 125 ; lalantjá re slubifát re jàfalím, 1450; slubisizei

46) Zeer veelvuldig komt dit ook voor in het Gebe, dat nauw aan het Bulisch verwant is, bijv. flòtansá, tien (klapperbomen, palen, atap); giatsá, tien (cocosnoten); taulsá, tien (borden); fessá, tien (pakken sagoe); alansá, tien (fakkels); wotsá, tien (mensen, huizen); tenitsá, tien (vademen); en ook flontanlú, twintig; giattól, dertig; taulfát, veertig; alanwònam, zestig; tenitlím, vijftig; maar van mensen, huizen en pakken sagoe zegt men àfalú, twintig; àfafát, veertig, enz. $(a f a=$ Bul. $j a ̀ f a)$.

47) Voor de grondvormen der telwoorden zie Robidé v. d. Aa, Vluchtige opmerkingen over de talen der Halmahera-groep, p. 270, en F. J. F. v. Hasselt, Spraakkunst der Nufoorsche taal, p. 31. 
re jàfasiwi re isiwi, 999; laksa failú re lalantjá re slubiwònam re jàfawai re silím, 21685 , enz. ${ }^{48}$ ).

Men verbindt de telwoorden ook wel met pers. vnw., bijv. silú, zijlieden twee; isa, hij, zij, het, een; memulim, gijlieden vijf ; meulú, gijlieden twee; itlú, wij (incl.) twee; amlú, wij (excl.) twee; it farum, wij (incl.) allen (te zamen); sililu, zij twee aan twee.

\section{Classificerende hulptelwoorden.}

Evenals in het Maleis en andere Indonesische talen maakt men ook in het Bulisch gebruik van classificerende hulptelwoorden, die, hun eigenlijke betekenis vrijwel verloren hebbend, zoveel als ons „stuks” gaan betekenen. Men plaatst ze tussen het substantief en het telwoord, dat steeds achter het substantief te staan komt. Deze woordjes zijn :

$i$, pers. vnw. 3e pers. ev., hij, zij, het $\left.{ }^{49}\right)$. Isa, hij, zij, het één, bijv. smat isa, een mens, iemand; fun isa, een hond; tatale wawaio isa, een kuiken; bet isa, een tuin; usi isa, een rib; kamal isa; een kamer; lolo isa, een dal ; paplaki isa, een naald; nokon isa, een zak; sasaro isa, een matras.

si, pers. vnw. 3e pers. mv., zijlieden; silu, zijlieden twee, bijv. smat silú, twee mensen; fun silú, twee honden; bebe wawaio sitól, drie eendkuikens; paplaki sifit, zeven naalden. Voor negen heeft men evenwel slechts isiwr, uit sisiwi (Waigeo si, Gebe sisiu, stam siu), smat isiwi, negen mensen.

Uit deze voorbeelden blijkt, dat $i$ en si gebezigd worden voor mensen, dieren en sommige voorwerpen.

$a$ in asa en sa in salú, satól, enz. worden gebezigd voor het tellen van prauwen en daarop gelijkende voorwerpen, zoals bijv. sagoebakken; pelang asá, een prauw ; fau asá, een sagoebak; pelang satól, drie prauwen; fau safit, zeven sagoebakken, enz.

$p i$, dat voor $s a$, één, in $p u$ verandert (het Gebe heeft pisa), wordt meestal alleen voor zaken en voorwerpen gebezigd, maar ook voor dag en nacht, geld, woonplaatsen, gewichten en maten, bijv. wōl pusa, één dag; dòram pusa, één nacht; rupia pusa, één gulden; rèspès pifát, vier guldens; pnu pusa, één dorp; pnu piwai, acht dorpen; ian motmòto

48) Dr. Esser stelde mij de vraag, of de oorspronkelijke methode ook geweest kan zijn zuivere achter-elkander-stelling zonder het voegwoord re. Ik kan dat niet uitmaken. In de verwante talen van Zuid-Halmahera komt ook het gebruik van re (Makj. lo, Waigeo to) voor.

49) Wat omtrent de telwoorden door N. Adriani (De Barese sprekende Toradja's, dl. III, p. 333-334) wordt gezegd, is later gebleken minder juist te zijn. 
pusa, één moot vis; pingkul pusa, één pikoel; sapa pusa, één kom; wōl pilú, twee dagen; sapa pilim, vijf kommen.

$a i$, hout, boom, wordt gebruikt voor bomen, lange voorwerpen als palen, masten ook voor huizen, enz., bijv. ebai aisá, één huis; waga ailú, twee cocosbomen; titial aitjól, drie stokken, as aifit, vier daksparren.

ara, geleding, bezigt men voor alles, wat geledingen heeft: bamboe, vingerleden, woorden, enz., bijv. sop arasá, één geleding bamboe, ook: één bamboe; fnai analim, vijf stuks fnai, s.v. bamboe; lobo aralú, twee vingers; maumauting arasá, één woord.

$b a$, (misschien $=w a$ ?), voor dunne voorwerpen, als boombladeren, papier, enz., bijv. ulū basá, één boomblad; kartas batol, drie vellen papier.

wa, wortel, voor brieven, messen, griffels, enz., bijv. surat wa isá, één stuks brief ; ni dèl wa isá, één zijn metgezel; cta was isá, één stuks mes; mangsi wa isá, één stuks griffel. Dus wa isá, waar men wasá zou verwachten.

bela (vgl. Mal. bĕlah), splijtsel, voor planken; fafan belafát, vier stuks planken.

bia (vgl. Mal. bilah?) voor lange, dunne voorwerpen, als bezems, visstekers, enz., bijv. leslesan biasá, één bezem; sosobā biafát, vier visstekers.

esing, kam bananen, voor bananen, bijv. tela esingtól, drie kammen bananen.

ese, enige, ook stoel bamboe, enz., voor bamboe, rotan enz., bijv. tonga ese, een stoel tonga (tonga, s.v. rotan).

folas, slaan op een wig om iets te splijten; ai folassá, één stuk hout (gereed gemaakt om te worden gespleten tot balken of planken).

jai, zwerm, voor dieren, die in zwermen leven; saninipa jaisá, één zwerm wespen; men zegt ook wel jai pusa, dan heeft het woord zijn karakter als class, telw. min of meer verloren.

kas, splijtsel, snijdsel, snede, schijf, voor planken, stukken, schijven v. aardvruchten, enz. Fafan kasfit, zeven stuks planken; fajau kasfát, vier schijven keladi.

peo, pit, voor lucifers enz., bijv. gares peo sloebifát, vier honderd stuks lucifers.

seal, paar, sealtjá, een paar; seal-lú, twee paar; seal-zwai, acht paar. smo, tand, voor atap; jataf smosá, één stuks atap; jataf smosizer, negen stuks atap.

De bovengenoemde woorden voor tiental, tanat, flòtan en tazill, kan 
men ook als classificerende hulptelwoorden beschouwen. Tanat gebruikt men voor vademen, flòtan voor lange voorwerpen als bamboe, palen enz. en tawil voor een sleep of een aaneengebonden reeks prauwen van tien stuks. Sop flòtantjá re aisá, elf stuks bamboe; tanattjá re loflú, twaalf vademen; pelang tareiltjá re sawònam, zestien stuks prauwen. Men zegt evenwel zeer eigenaardig tanat slubisá, 100 vadem, terwij1 men zou menen, dat het $10 \times 100$ vadem zou betekenen.

Er zullen hoogstwaarschijnlijk nog wel meer dergelijke class. hulptelw. bestaan.

Bij getallen boven tien gebruikt men deze class. hulptelw. aldus: waga aijàfasá re ailú, 12 stuks cocosbomen; cbai aijàfatól re airwai, 38 stuks huizen; jataf smoslubisá re smojàfafát, 140 bladen atap.

\section{Rangtelwoorden.}

In het Bulisch ontbreekt een bepaalde vorm voor rangtelwoorden. Men bezigt het telwoord in zijn gewone vorm, soms voorafgegaan door het betr. vnw. ta, die, dat, bijv. tita pitól, het derde gebod (lett.: drie geboden); tita jàfasá, het tiende gebod, ook: tien geboden; wōl ta pitól, dag die drie, de derde dag; zvōl ta pifít, de zevende dag; ta wōl pilú, de tweede dag. Of men gebruikt ook wel de vorm van de hieronder te bespreken vermenigvuldigende telwoorden, bijv. tjagulu failú na, het tweede raadsel. Alleen voor: eerste, voorste, cn laatste, achterste, heeft men bepaalde woorden: tuba, voorste, eerste; ta tuba, de, het voorste, eerste; amtuba, gij eerst; takapó, eerste, w'ól takapó, de eerste dag; soms nog versterkt door famafia, goed, zeer; wōl takapo famafia, de allereerste dag; mesamul, laatste, achterste.

Van een eerste kind zegt men tauatí, de oudste, van het jongste tawarwai, en van het laatstgeborene ntu sus farano, het kind, dat aan het zogen een grens stelt.

Voor een enig kind zegt men: wareai tuping, ntu tuping; waga tuping, één cocosnoot aan een tros, een éénling; tweeling is : wawai iru; dubbel, bijv. van twee bananen in één schil, is : fatjitjapal; een dubbelloopsgeweer is : snapān sosera. Voor één van een tweetal, bijv. horens, oren, armen, benen, schelpen enz., zegt men: pao, de helft, één zijde; nim sapi tja ni tado pao mgoi, één van de horens van uw koe is gebroken, geknakt.

Voorts heeft men nog verzamelende en andere telwoorden, wijzigingen van het telwoord tot het aangeven van groepen, delen, enz., bijv. faisá, fapusa, faaisá, één enkele, één op zichzelf. Men bezigt dus 
het voorvoegsel fa, en zegt ook fasilú, fasalú, faailú, fasifát, fasifit, enz., een tweetal, een viertal, een zevental enz. Kastéla fapusa be, slechts één enkel stuks mais; nga fasilú, een tweetal, een paar maanden; pelang fasalú, een paar, een tweetal prauwen; tela faailú, een paar, een tweetal trossen bananen; men zegt ook fabàhnga, één enkele; mpo waja òk fabàhnga, geef een enkele teug water.

\section{Vermeniguuldigende telwoorden en breuken.}

De vermenigvuldigende telwoorden worden gevormd door het prefix fai- ${ }^{50}$ ), bijv. failu, tweemaal; faiwai, achtmaal; faiàfasa re faifát, veertienmaal. Men zegt evenwel niet faitól, maar faitjól, driemaal, en voor éénmaal bàhnga. Faislubisá re faijàfalú re faitjól, 123 maal. Deze vorm van de telwoorden wordt ook gebruikt bij woorden als taun, jaar, taun bàhnga, één jaar; musum bàhnga, één jaargetijde, een halfjaar; djumat faifát, vier weken; taun faitjól, drie jaar; laksa bàhnga, 10.000; juta bàhnga, 1.000.000; en bij lengtematen als: asuna bàhnga, één vadem; asta bàhnga, één el; falai bàhnga, één handbreed; en bij maten voor droge en natte waren: kopis bàhnga, één kopje; itif bàhnga, één spogje; tektek bàhnga, één droppel; òk bàhnga, één teug, pilu faifát ndadi pizeaí, twee viermaal wordt acht.

Voor uitdrukkingen als ons derdehalf, vierdehalf enz. zegt de Buliër : làse bon sitći, bijna het zal drie zijn, $2 \frac{1}{2} / 2$; làse bon sifát, $3 \frac{1}{2} 2$; làse bon sizeái, $71 / 2$ enz.

Breuken worden uitgedrukt met behulp van pao, helft, zijde, en diran, deel, gedeelte, bijv. 11/2 gulden, respes pusa re pao; $11 / 2$ gulden, rupia of respes pao; kakamo pao $=1 / 2$ vadem. Dirantjá, één gedeelte; diranlú, twee gedeelten; isizer dloat dirantól laisawa sitól, $9: 3=3$ (letterl. 9 zij delen drie delen is gelijk drie).

Men gebruikt wel het Hollandse woord kwar $(t)$ voor $1 / 4$ gulden, maar het heeft niet de betekenis van $1 / 4$.

Om te vermenigvuldigen zegt men: pilú failú pifát pa ga?, twee, tweemaal, vier, niet waar?

\section{Verdelende telwoorden.}

Verdelende telwoorden zou men kunnen noemen die, welke door reduplicatie of geminatie worden gevormd, als: isa-isa, één voor

50) Vgl. H. Kern, De Fidjitaal enz. p. 46 en 51. 
één, elk, ieder één; pusa-pusa, id.; ai tjutjuping, elk één stuks; lilu, elk, ieder twee, twee aan twee; ailitú, ieder twee stuks; tjitjól, elk drie, drie aan drie; fifát, elk vier, vier aan vier; limlím, elk vijf, vijf aan vijf; wizwònam, elk zes, zes aan zes; fit-fit, elk zeven, zeven aan zeven; wizwái, elk acht, acht aan acht; sizri-sizwi, negen aan negen, elk negen; jàfasá-jàfasá, elk tien, tien aan tien; jàfalilú, elk twintig, twintig aan twintig enz.; ai flòtan tjutjuping, elk tien stuks, tien aan tien stuks; ai flòtanlilu, elk twintig stuks, twintig aan twintig stuks.

Ons : bij tientallen, honderdtallen, honderden enz. duidt men in het Bulisch aan met het voegwoord $r e$, en, en het achtervoegsel $-o$, bijv. rejàfo, bij tientallen; reslubo, bij honderden; relalno, bij duizenden; retaulo (prauwen) bij tientallen; pelang jà retaulo, de prauwen bij tientallen; smat ta reslubo, honderden mensen, de mensen bij honderden; ian ta relalno, duizenden vissen, de vissen bij duizenden.

\section{Onbepaalde telwoorden.}

Onbepaalde telwoorden zijn: dumi, farumi, nafale, sagala (Mal. sĕgala), lāl, kòtjé, wakòtjé, okòtjisi, paisa, ise-ise, salemòma, ponlālo, okòtjisi lālo, itji kurang (Mal. id.), nenèna, using lālo, rupa-rupa (Mal. id.), fakòtjé, faitji, diran, fadiran, isa-pa.

Dumi, alle, alles, geheel en al, bijv. mani tiná dopa ddumi tò, die vogels zij vlogen alle reeds weg; pira tja luf dtetal ndumi, de sagoekoek de muizen zij aten geheel en al op; janik badan taie npirpir ndumi, dit mijn lichaam doet geheel en al pijn.

Farumi (dumi met prefix $f a$-, de $d$ gaat over in $r$, zie klankleer), alle tezamen, allemaal, bijv. smat tadpisi farumi, al de mensen, die ziek waren, de mensen, die ziek waren allemaal; fare karkār nèsa farumi, en al de andere padden te zamen; it farumi smat Buli, wij zijn allemaal Buliërs.

Nafale, alle, bijv. nafale smat lifo renta duwe, alle vreemdelingen moeten terugkeren; nafale ai pio ta lālo, alle vruchtbomen, die velerlei waren; bo nafale smat farumi dderera, opdat alle mensen samen volgen.

Sagala, alle.

$L \bar{a} l$, veel, vele, bijv. $l \bar{a} l$ be waktu salaka, veel ook zilveren horloges; lāl be gu bisa, er zijn ook veel giftige slangen; smat lāl tiná ddelluá?, waarheen gaan die vele mensen? tuang ni sapi ja läl, de koeien van mijnheer zijn veel; nau tja ni asil ja lăl mali it, de arènboom zijn voortbrengselen zijn vele voor ons.

Kòtjé, met wa, wakòtjé en met fa, fakòtjé, een beetje, een weinig, eventjes, bijv. ndor tabako wakòtjé, hij vroeg een beetje tabak; pirpir 
reakòtjé, een beetje ziek, onwel; tofnga tofang fakòtjé, laat een beetje proeven.

Okòtjé, weinig, een beetje; fare bebe njāl okòtjé ga nān, en de eend nam een beetje vervolgens zij at; mnu okotjé tò, al een beetje lang.

Okòtjesi, okòtjisi (van okòtjé), iets, wat, alles; sagala okòtjisi lālo farumi, alles, wat is, bestaat; fare ni okòtjesi ta mafia re karamat na, en al het zijne, dat mooi en prachtig was; okòtjisi lālo, alles er van, allerlei, alles; okòtjisi lälo ta ndadikan na, alles, wat Hij geschapen had.

Paisa = faisá (?), iets, wat, bijv. paisa pa, niets, nul; gabe ikut paisa pa, indien ik niets meebreng.

Pusa-pusa, elk een, elk, bijv. ān pusa-pusa, elke spijs.

Isa-isa, elk een, elk, bijv. mali kamal isa-isa loló, in elke kamer.

Salemòma, al wat, alles; salemòma ta majai, alles wat slecht is; salemòma ta mtō paube na, alles wat gij nog niet kent.

Ponlālo, alles er van.

Itji (uit het Tern., Tid. id.), weinig, een beetje; faitji, een weinig; faitji pa, niet zo'n beetje; ian tja nmamàgal faitji pa, die vis is niet zo'n beetje groot, d.w.z. is groot.

Kurang, weinig.

Nenèna, weinig, bijv. nenèna pa, niet weinig.

Using lālo, allerlei soorten, bijv. ian using lālo, allerlei, velerlei soorten vis.

Rupa-rupa, allerlei soorten.

Diran, deel, gedeelte, fadiran, een bepaald deel, enige; smat dirantjá, een deel van de mensen; sapi fadirantjá, enige koeien; gina fadirantjá, enige goederen.

Het vragend telwoord is fis, hoeveel ; het wordt verbonden ook met de class. hulptelwoorden, dus : sifís, safís, aifís enz.; rupia sifis? hoeveel gulden(s)?; faifís, hoeveel maal?; tok faifís taine?, hoeveel keer heeft het nu geslagen?, hoe laat is het nu?; fapifis?, hoeveel te zamen? 
HOOFDSTUK IV.

Het voornaam oord.

1. Aanwijzende voornaamwoorden.

De aanw. vnw. komen in twee vormen voor:

en kelvoud

$t j i a$, korte vorm: $t j a$, die, dat, het

taie, korte vorm: tai, deze, dit meervoud tiná, korte vorm: na, die tasiá, tasine, tasá, die taine, korte vorm: tane, deze

Tenzij zelfstandig gebruikt, staan zij steeds achter de woorden, die zij bepalen, bijv. fun tja, die hond; anam bet tiná, die uw tuinen.

Men gebruikt de aanw. vnw. niet alleen tot nadere bepaling van substantieven, maar ook van pers. vnw. Ze vervullen dikwijls de functie van bijwoorden van tijd en plaats. Het zijn vooral tane, taine en tasine, die als bijwoorden van tijd en plaats optreden.

Een aantal woorden vervullen soms ongeveer dezelfde functie als de Ned. bepalende lidwoorden de en het. Het zijn : het aanwijzend vnw. enkelvoud $t j a$, die, dat, of ook wel tjia (verband met sia?), het betrekkelijke vnw. $t a$, die, dat, de nadrukswijzer $o$, het woordje $j a$ (dat mij niet geheel duidelijk is) en het suffix -ta en voor het meervoud, de aanwijzende vnw. tasiá, die, tiná, die, verkort tot $n a$. Het telwoord isa, één of pussa, één heeft in bepaalde gevallen de kracht van ons onbepaalde lidwoord een. $Z \mathrm{ij}$ worden alle achter de substantieven geplaatst.

Het is vooral het zinsverband, dat ons laat gevoelen, waar bovengenoemde woordjes als lidwoord optreden, bijv. bebe na numat tja njälo, de branding nam die van de eend; fare luf tja ntolē, fare ntjagu pelang tja, en de muis was boos en hij stak het vaartuig; gu tja re fitjo pa, de slang heeft geen poten; amekut bòki isa lali lop tja sapngo na, wij brachten een kat derwaarts (bij) de uitgang van het gat; mningo zeōl tja, kijk naar de zon; nau tja ni asil ja lāl mali it, de voortbrengselen van de arènpalm zijn vele voor ons; kapalo, het schip!; balk mano, de mannetjesbalk; tareareai, de jongste; tanati, de oudste; kabil silú tasiá, de beide geiten; mali saja talalo tiná, onder de bloemen, die velerlei zijn; luf tiná dnafsu $t u$, de muizen zijn zeer begerig; luf na dtetal $i$ tò, de muizen hebben het aangevreten; eantá, het pleegkind; gutá, de slang (vgl. oloantá, het dorpshoofd; ngolotá, de echtgenote enz.); mali pnu pusa, in een zekere plaats; nok isa nème ni tuan, een aap zag zijn heer (meester); wōl pusa nfān, op een dag ging hij; sudagan isa bonfalai, een handelaar zou op reis gaan. 
$N a$ komt zeer dikwijls in allerlei zinsverband voor, bijv. op het eind van een zin met een werkwoord in de vetatief, als: mati mlois ná, wil niet stelen, steel niet; mati tfamamàgal it ná, vergroten, verheffen wij ons niet (vgl. Mak. $i(k i)$, teyako lukaki, wil niet stelen, steel niet).

Verder komen de aanw. vnw. veel voor in allerlei samenstellingen van bijwoordelijke aard ${ }^{51}$ ), bijv. nagá, bená, denabé, laitane, lainá, ta tiná tò.

Voorbeelden van gebruik: fare tét tja namsai pa, en het brugje was niet breed (smal) ; mali bet tja loló, in die tuin; D jou Lahatala ndadikan dunia taie, de Here God schiep deze wereld; smat taie, deze mens; ja boidom waja taie, ik wil dit water drinken; taie mutiara pusa, dit is een parel; denabé laflaf tiná ntjapang, totdat het bloed er uit kwam; ise ulo lolò bonān lilit pio taine?, wie houdt er van deze mangga-vrucht te eten?; meu fān( $\breve{e})$ pio na farumi, gijl. eet die vruchten alle; fun tja nlep ān tiná, de hond likte dat eten op (lep, likkend eten als een hond); anam bet tiná, uw tuin die (daar); ai ailú tasiá, die beide bomen; kabil silú tasiá, die beide geiten; wàngat tane, jawangtok, dat vlees, mijn vlees; troi tane pilú, dat zijn twee dobbelstenen; ja tane, ja taine, ik deze (met nadruk); ja taine Djou, men ni men Djou Lahatala, Ik deze de Here uw God; laisawa tane, laisawa taine, gelijk deze, hier, nu; smat ta nafetang taine, de mens, die dit vertelde; ai ailú ta mali bet fapaluno tasine, deze twee bomen, die in het midden van de tuin waren (zijn); an taine mnao laisarea?, hoe is het lekkere van dit eten?; janik tjagulu silú tasine, deze mijn twee raadsels; fare rearwai tasine dmamàgal, vervolgens deze twee kinderen zij waren groot; fare ntjia smo na, bonaf $(\breve{e})$ smat tasiá, vervolgens opende hij zijn bek willende die mensen tegenspreken.

\section{Persoonlijke voornaamwoorden.}

De pers. vnw. komen eveneens in twee vormen voor $\left.{ }^{52}\right)$ :

$$
\text { en kelvoud }
$$

$j a$, korte vorm: $i$ of $i k, \mathrm{ik}^{53}$ )

awe, au, , am of $m$, jij

$i, \quad \quad, \quad n$, hij, zij, het me e r vou d

ite, korte vorm: $t$, wij (incl.)

$\operatorname{ame}(k) \quad, \quad k$, wij (excl.)

meu, $\quad, \quad f$, gijlieden

si, sile, sil " $\quad d$, zijlieden

De korte vormen treden alleen op in de vervoeging.

51) Zie hoofdstuk VI.

52) Vgl. N. Adriani, De Barese sprekende Toradja's, dl. III, p. 329 e.v.

53) Onjuist is wat R. Haaksma schrijft in zijn "Inleiding tot de studie der vervoegde vormen in de Indonesische talen” (1933), p. 166, nl. „dat bij stammen, 
De zelfstandige vorm ja komt ook voor als object, bijv. ampun ja, gij slaat mij. Wellicht is de $j$ overblijfsel van het lidwoord $i$ of $s i$, dat de pers. vnw. in vele talen voor zich hebben, bijv. Sang. $i a^{s}$, Bar. jaku (vgl. Pat. aja en ake, Nuf. $(a) j a{ }^{54}$ ), Leb. $a k$ ). Jaku moet in het Bulisch $j a k$ worden gelijk $k u$ tot $k$ is geworden, zoals dat bijv. in het Saw. Mab. en Makj. is gebeurd, waar de vorm $j a k$ is. Het Bulisch heeft, naar wij zagen, vaak vormen zonder $k$, waar verwante talen vaak vormen met $k$ hebben. De $k$ verschijnt evenwel weer voor werkwoordstammen, die met een vocaal beginnen.

Toen Dr. Adriani zijn reeds meermalen geciteerde schets van het Bulisch samenstelde, verkeerden wij nog in de mening, dat de zelfst. vorm van het pers. vnw. 1e pers. enkelv. jai was. Haaksma nam dat over ${ }^{55}$ ), doch Dr. Esser maakte er mij opmerkzaam op, dat niet jai, doch $j a$ de zelfstandige vorm is. Dat blijkt bijv. uit $j a$ lalan, ik zeewaarts; $i$ re ja kfaungo si, hij en ik, wij joegen ze weg (vgl. ook de vormen van het bezittelijk vnw.); ja tain, ik hier, ik deze (met nadruk). Daardoor zijn de door Dr. Adriani genoemde bezwaren en moeilijkheden vervallen.

Als procl. pron. 1e pers. enkelv. komt ook $i$ voor; deze $i$ representeert $j$ in $j a$ en is dus het formatieve gedeelte van het pron. in de plaats van het eigenlijke pron. optredend. Zie Nuf. 1e pers. enkelv. ${ }^{56}$ ). Vgl. Gebe anejem, ik zie, stam em, zien; ancpialas, ik betaal, stam palas, betalen; anedjom, ik drink, stam dom, drinken; Pat. ajapialas, ik betaal, stam palas, betalen; Mab. jakjem, ik zie, stam em, zien; jakdjem, ik drink, stam $d e m$, drinken. In deze talen wordt de $i$ of $j$ geïncorporeerd, wat in het Bulisch niet gebeurt.

Werkwoordelijke stammen, welke met een klinker beginnen, krijgen $i k(i+k)$ voorgevoegd, bijv. ikem, ik zie, ikut, ik breng.

Werkwoordelijke stammen, welke met een consonant beginnen,

welke met een vocaal beginnen, in de vervoeging een procl. pron. optreedt, dat slechts uit een consonant bestaat". Ook bij stammen, die met een medeklinker beginnen is dat zo. De uitzondering is, dat bij stammen, die met een vocaal beginnen in de le pers. enkelv. niet slechts $k$ voorgevoegd wordt, maar $i k(i+k)$ terwijl stammen die met een consonant beginnen alleen $i$ krijgen, bijv. van $e m$, zien, ikem, ik zie; van dom, drinken, idom, ik drink; jai is een verbinding van $j a$ en $i$; $j a$ is het zelfst. personale. De volledige vervoeging is jaikem, ik, ik zie; jaidom, ik, ik drink. Indien het subject een nomen is, blijft het zelfst. pron. achterwege.

54) F. J. P. v. Hasselt, Nufoorsche Spraakkunst (1905), p. 33.

55) R. Haaksma, o.c. p. 167.

56) R. Haaksma, o.c. p. 167.

Verh. dl. X. 
krijgen alleen $i$ voorgevoegd; voorbeelden zijn: idom, ik drink; ipes, ik sla hem; igogan ja, ik verberg mij; ifasarea au, ik trouw met je.

Het vnw. awe of $a u$ wordt soms door fonetische omstandigheden tot $a$ verkort. De zelfst. vorm $a u$ komt ook voor als object. De korte vorm is $a m$ of $m$. Wellicht is de zelfst. vorm awe ontstaan uit $a u+$ de interjectie $e$, gij! De vorm $a u, a$ is het Mal. Pol. kau, de vorm $m$ is het Mal. Pol. $m u$, dat met kau synoniem is. Au malì, hij herwaarts; $m f a \bar{n}$, ga; amem, gij ziet; amseli, gij eet; ise npun au?, wie heeft $\mathfrak{u}$ gedood?; amgogan au, gij verbergt $\mathrm{u}$.

Van het vnw. v.d. 3e pers. komt de zelfst. vorm $i$ o.a. voor als objectsvorm, bijv. jaigogan $i$, ik, ik verberg hem. De vorm $i$ komt overeen met Mal. Pol. ia, n met Mal. Pol. na. Indom, hij, hij drinkt; smat tja nān pira, die man eet sagoe; inem ja pa, hij, hij ziet mij niet.

Van het vnw. 1e pers. meerv. incl. ite, korte vorm $t$ is de objectsvorm $i t$, bijv. laisawa ibonlolol it, alsof hij ons wil wekken. Ook in samenstellingen komt it voor, bijv. itlú, wij twee, wij beiden. De vorm ite is Mal. Pol. kita, de vorm $t$ het Mal. Pol. ta, korte vorm van kita. Itetfän, wij, we gaan; mtuli mali su bottamaga, kom eerst hier aan, opdat wij sirihpinang kauwen; itetdom waja, wij drinken water; itettjeli paubé, wij, wij hebben nog niet gegeten.

Van het vnw. 1e pers. meerv. excl. ame(k), korte vorm $k$, is de objectsvorm am, bijv. indela am pa, hij gelooft ons niet; sidem am pa, zij, ze zien ons niet.

De vorm ame $(k)$ is het Mal. Pol. kami, $k$ is Mal. Pol. $k a$ of $k i$, de korte vorm van kami $\left.{ }^{57}\right)$. Amekfān, wij gaan; amekem, wij zien; $i$ re ja kfaungo si, hij en ik, wij joegen ze weg; ameksali, wij roeien ${ }^{58}$ ).

Van het pers. vnw. van de 2e pers. meerv. $\operatorname{meu}(f)$, korte vorm $f$, is de objectsvorm meu. Ise npun meu?, wie heeft jelui geslagen?. Dit meu correspondeert met miu in de West-Toradjasche en Minahassische talen (miu, mio, miow). De $f$ is een verscherpte $w$, welke op haar beurt weer ontstaan is uit $u$, de uitgang van miu. Voorbeelden zijn : meuffa $\bar{a}$, gij, gij gaat; meufdom, gij drinkt; fem, ziet!; jaboigogan meu, ik, ik zal jelui verbergen. Vgl. Waig. mia, mezwa; Salaw. mea.

Van het pers. vnw. van de 3e pers. meerv. sile, sili, sil of si(d), korte

57) Zie R. Haaksma, o.c. en Esser's bespreking in T.B.G. 1935.

58) R. Haaksma, o.c. p. 167 nam een fout over van Dr. Adriani, De Barese sprekende Toradja's, dl. III, p. 321, toen hij schreef : „Uit den vervoegden vorm amek cale blijkt, dat ook de verbinding $k s>k c$." 1 . plur. incl. $t$ - staat voor ta-, het zelfst. personale ite = kita. De verv.vorm is ameksali, wij wij (excl.) roeien, van een stam sali, roeien. 
vorm $d$, is de objectsvorm si of sili. De volledige vorm van dit pronis volgens Dr. Adriani sira, dat in verschillende vormen (sera, sia, ra, $n d a$, da, sira, si, sila) in de Indonesische talen wordt teruggevonden ${ }^{59}$ ). Vgl. Wed. si; Geb. sia; enz.

De korte vorm $d$ correspondeert met Indon. $r, n d a, d a$ en andere vormen; vgl. Wed., Saw., Makj. Geb., Pat. $r$, si(r). De vorm si wordt ook gevoegd achter volks- of persoonsnamen, om het meervoud of een collectivum aan te duiden, bijv. Slamsi, de Mohammedanen, Saranisi, de Christenen; Gebsi, de Geberezen, de lieden van Gebe; deltji, de makkers; hmā re hnjēsi, de ouders; siledfän, silfān, zij, zij gaan; sidem, zij, zij zien; kiai tiná dfān lalı̄ pnu Padang dwage diel rari lilewing lalo, die Chinezen, zijn gaan derwaarts naar de stad Padang, zij verkopen, zij gaan rond (met) hun verschillende groenten; jaikem si pantò, ik, ik zie hen niet meer; mali sili, aan hen.

$\mathrm{Bij}$ de vervoeging wordt de korte vorm van het pers. vnw. vóór de stam van het werkwoord gevoegd en daarna wordt de volledige vorm van het pron. nog eens daarvoor gezet, bijv. jaikut pupi, ik, ' $\mathrm{k}$ breng sagoe (ut, brengen); induk pupi, hij ie-krijgt sagoe; itetozril, wij wehebben koorts (owil, koorts); siledfo, zij ze-persen uit. Wanneer de werkwoordstam met een medeklinker begint, wordt de $k$ van de 1e pers. enkelv. niet voorgevoegd, doch die van de le pers. meerv. excl. wel. Voorbeelden zijn: igali au pa, ik help je niet; iwagfo luf tja, ik ving die muis; ntuk ta idodara $i$ tja, die mijn zoon waarvan ik houd, die ik liefheb; kgali meu pa, wij (excl.) helpen jelui niet; kfän paubé, wij gaan nog niet; kwagfo luf taie, wij vingen deze muizen.

Indien het subject zelf met name genoemd wordt, of in de vorige zin reeds genoemd is, vervalt de volledige vorm van het pers. vnw. en bezigt men alleen de korte vorm, bijv. bou na dān zeaga, de varkens ze-eten cocosnoten; tatale $m \bar{a} n$ tja nkuku, de haan ie-kraait. Dit geldt ook voor het pron. poss., bijv. bou na riri kalakuang, de varkens hun wijze van doen; bou na ulori loló dtjamas mali pererek na, de varkens ze-houden er van ze liggen (wentelen zich) in de modder.

De pers. vwn. worden steeds herhaald in zinnen als : jaikem an amfarera, ik 'k zag u gij vluchtet, ik zag u vluchten. Zo ook intjula ja ifän, hij, hij beval mij ik ging, hij beval mij te gaan; jaidor tulungan mail tuka tja, ngali ja, ik, ik vroeg hulp aan de tukang mij te helpen (hij hielp me); pehaha ga ambarani mfatjòtjòmá waja tja?, waarom zijt gij zo

59) Vg1. R. Haaksma, o.c. Volgens Esser bestaat sira uit si en ra, zodat ra ( $n d a)$ en si niet als (verkorte) vormen van sira behoeven te worden beschouwd. 
brutaal, gij maakt het water troebel?; fare nut $i$ lalei ailoló, fare nān $i$, vervolgens bracht hij het in het bos, hij at het.

Over de verbinding van de pers. vnw. met telwoorden is reeds gesproken in het vorige hoofdstuk.

Een eigenlijk wederkerend vnw. bezit het Bulisch niet; men bezigt de objectsvormen der pers. pron., nl.: $j a, a u, i, a m, i t$, meu en si, bijv. jaipun ja, ik, ik sla mij; ampun au, gij, gij slaat $\mathrm{u}$; in-gogan $i$, hij, hij verbergt zich. Bovendien bestaan er afleidingen met reflexieve betekenis, die later ter sprake zullen komen.

Door de toenemende invloed van het Maleis wordt soms gebruik gemaakt van het Mal. diri voorafgegaan door $n i$; dit geldt echter niet als correct Bulisch. Voorbeelden zijn: mati mfulta ni diri re smat nèsa ni karadjāng na, men menge zich niet in het werk van een ander; isa isa ulo-ja neto be ni diri, een ieder denkt slechts aan zichzelf.

Met Ned. zelf komt overeen tutuling, dat ook alleen betekent. Jaitutuling, ikzelf, ik, ik alleen; amtutuling, gijzelf, gij, gij alleen; au re ise? jaitutuiling, gij en wie? ik ikzelf, alleen. Soms wordt ni diri tutuling gebruikt, bijv. ise ta ulo-ja neto be ni diri tutuling, ieder, die slechts aan zichzelf alleen denkt.

Met Ned. zijn eigen, mijn eigen, enz. correspondeert in het Bulisch fatutulnge, bijv. ni karadjāng fatutulnge, zijn eigen werk; nim sāl fatutulnge, uw eigen fout, schuld; janak fatutulnge, pa, het is niet van (voor) mijzelf ; siriri tjitjoal fatutulnge, hun eigen kracht.

Ons elkander wordt door het verbale prefix $f a$ - angeduid, soms met reduplicatie of herhaling van het werkwoord (zie Hoofdstuk V), bijv. fadupduping, elkander ontmoeten.

\section{Bezittelijke voornaamwoorden ${ }^{60}$ ).}

De bezit. vnw. bestaan uit twee elementen, waarvan er één vóór het door hen bepaalde woord wordt gevoegd en één, een korter element, er achter ${ }^{61}$ ) aldus :

$$
\begin{array}{ccc}
\multicolumn{3}{c}{\text { e } \mathrm{nkel} \text { vou d }} \\
j a & \ldots \ldots & k \\
a & \ldots & m \\
i & \ldots \ldots & \\
& \ldots \ldots & \left.o^{62}\right)
\end{array}
$$

me e rvoud

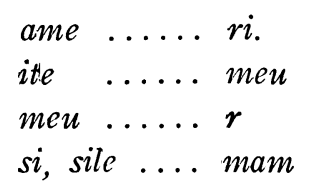

60) Vg1. Esser, T.B.G. 1935 , p. 313 en Klank- en Vormleer van het Morisch, deel I, § 142, p. 95; voorts Haaksma, o.c., p. 168.

61) Zie N. Adriani, De Bares e sprekende Toradja's, dl. III, p. 330.

62) Dr. Adriani bespreekt in De Barese sprekende Toradja's dl. III, p. 307, 
Deze vormen komen overeen met de volgende Indonesische vormen der bezit. vnw.:

1e pers. enkelv. $k u$

2e ,, , $\quad m u$ 1e pers. meerv. excl. mami

$2 \mathrm{e} \quad, \quad \quad, \quad$ miow, min, mio ${ }^{63}$ )

Voorbeeld van aanhechting der pron. poss. aan boboko, hoofd:

jabobokok, ik, mijn hoofd, mijn hoofd

abobokom gij, uw hoofd, uw hoofd

iboboko hij, zijn hoofd, zijn of haar hoofd

amebobokomam wij, ons hoofd, ons (excl.) hoofd

itebobokòr wij, ons hoofd, ons (incl.) hoofd

meubobokomeu $\mathrm{u}$, uw hoofd, uw hoofd

silebobokori zij, hun hoofd, hun hoofd ${ }^{64}$ )

308 (zie ook p. 332 333) het suffix o, dat in het Bulisch voorkomt. Hij schrijft: Waarschijnlijk is -o meer als lidwoord op te vatten, dan als pron. suffix. Sommige woorden schijnen in het Bulisch altijd dit $-o$ te hebben; het is althans merkwaardig, dat de namen van lichaamsdelen bijna alle op -o uitgaan, bijv. bokoko (Saw. boboke), hoofd; kanjo, oor; guguo, neus; pero, lip; glao, keel; paleo, tong; ngalo, kin; ngengeo, wang; wao, hals; hnjao, buik (naast hnjai pàkal „maag”, letterl. grote buik; Mab. sjai naast sjao, Saw. snu, Geb. hnjai, Pat. sia) ; tao, rug; kakamo, hand, arm (Pat. kom); golo, staart enz. Van woorden als pero, golo, kakamo, bokoko is het zeer waarschijnlijk dat zij in stamvorm luiden par (Mal. bibir), gol (Mal. ekor), kakam (werktuignaam van kam, Jav. gam, gem, vastgrijpen), bobok (Bob. Loin. $u b a k$ ). Doch de -o schijnt in deze woorden aan het stamwoord te zijn vastgegroeid, daar gewoonlijk de $-r$ van het pron. suff. 1e pers. meerv. incl. er nog aan toegevoegd wordt; vraagt men het woord voor hoofd dan krijgt men ten antwoord bobokòr, ons hoofd, d.w.z. het menselijk hoofd en zo verder guguiòr, smor, glaòr, papleòr, enz. onze (menselijke) neus, mond, keel, tong.

Wij zouden verder ook nog kunnen wijzen op ngàhnjo naam, stam ngasan, klas, graad, naam, ambt, met de afleiding fangasan, een naam geven naast fangahnjo (vgl. Pat. ngeson, Wed. ngosang, Waigeo nasan, Mab. ngosnu) en ngahnjor, onze namen.

63) De heer J. E. Sondak te Tomohon was zo vriendelijk mij mede te delen, dat mio voorkomt in het Tombulu achter woorden, die eindigen op een klinker of hamza; achter woorden, die op een medeklinker eindigen, gebruikt men io; het Tonsea heeft miou, iu; het Tontemboan miow, iow.

Men vergelijke verder voor de Indon. vormen Haaksma, o.c. en de critiek daarop van Esser in T.B.G. 1935.

64) Vg1. F. J. F. v. Hasselt, Spraakkunst der Nufoorsche taal, p. 38.

Dr. Esser maakte tegenover mij de opmerking: ,r (1e pers. meerv. incl.) en $r i$ (3e pers.mv.) zullen ook wel Indon. equivalenten hebben. Haaksma schrijft: „Waaruit het poss. suffix $-r$ in deze pers. (1e pers.meerv. incl.) is ontstaan is niet duidelijk, tenzij men zou moeten aannemen, dat $-r$ staat voor $-r a$ en dat dit evenals in Asiloeloe ontstaan is uit -nta." Ik kan een en ander niet beoordelen. Het Gebe heeft itnekutot, ons hoofd, van een stam kuto, hoofd, dus een - $t$ en het Makj. een $-d$. 
Op deze wijze worden de bezit. vnw. gehecht aan de namen der lichaamsdelen, behalve wenkbrauwen, hoofdhaar en nagels, waarschijnlijk omdat die bloed- en gevoelloos zijn en geregeld worden geknipt of geschoren en dus niet vast tot het lichaam behoren. Verder wordt deze vorm gebruikt voor bloedverwanten, als: vader, moeder, ouders, broeder, zuster, kleinkind, doch niet van aangehuwde familieleden. Dit verschijnsel komt veel voor in de talen van Oost-Indonesië ${ }^{65}$ ).

De naam wordt eveneens als lichaamsdeel beschouwd en ook het gemoed, hart (ulo ja), benevens de samengestelde woorden, waarin ulo ja voorkomt, bijv. ulo ja mafia, goed hart.

\section{Voorbeelden zijn :}

jaulok ja mafia, mijn hart is goed aulom ja mafia, uw hart is goed iulo ja mafia, zijn, haar hart is goed ameulomam ja mafia, ons (excl.) hart is goed iteulor ja mafia, ons (incl.) hart is goed meuulomeu ja mafia, ulieder hart is goed siulori ja mafia, hun hart is goed

jaulok ja neto au, ik herinner mij $\mathrm{u}$ aulom ja neto $i$, gij herinnert $\mathrm{u}$ hem iulo ja neto $j a$, hij herinnert zich $\mathrm{mij}$

jaulok loló, ik houd er van, lett.: in mijn binnenste is aulom loló, gij houdt er van, lett.: in uw binnenste is ameulomam loló, wij (excl.) houden er van, lett.: in ons binnenste is.

Andere woorden die ook op deze wijze behandeld worden, zijn: $u$ hngo, aangezicht; lòngo, been; ruàngto, vlees; pio, vrucht; tolo, ei ; gagau, plaats, voetstap; ngahnjo, naam. De benamingen voor man en vrouw worden niet op deze wijze behandeld.

Al deze woorden gaan op $o$ uit, behalve gagau.

Voor de andere woorden zijn er twee wijzen, waarop zij met de bezit. vnw. worden verbonden. De eerste wijze is deze, dat de bezit. vnw. worden gehecht aan het partikel $n i$ en dat daar achter het substantief wordt gevoegd, dat de bezitting aanduidt. Deze wijze word gevolgd bij

85) R. Haaksma, o.c., Hoofdstuk VI en VII. 
de namen van voorwerpen als huizen, schepen, messen, kledingstukken, wapens, sommige gereedschappen, in het kort bij de meeste voorwerpsramen, ook bij haren en nagels, en bij het woord $l e$, haat, haten, dat als substantief wordt beschouwd. Voorbeelden van ebai, huis, zijn:

janik ebai, mijn huis, d.i. ja-ni-k ebai, ik, 't mijne huis

anim ebai, uw huis, d.i. $a$-ni-m ebai, gij, 't uwe huis

ini ebai, zijn huis, d.i. $i$-ni ebai, hij, 't zijne huis

amenimam ebai of animam ebai, ons (excl.) huis, d.i. ame-nimam of $a-n i$-mam ebai, wij 't ons huis

iterir ebai, ons (incl.) huis (ite-ri-r)

meunimeu ebai, ulieder huis (meu-ni-meu)

siriri cbai, hunlieder huis (si-ri-ri).

Zoals reeds is opgemerkt, worden de bezit. vnw. in bepaalde gevallen in hun korte vorm gebruikt, dus : nik ebai, nim ebai, riri le, enz.

Men ziet, dat bij de 1e pers. meerv. incl. en bij de 3e pers. meerv. de $n$ van $n i$ in $r$ is overgegaan, onder invloed van de volgende $r$; vgl. ook het beneden gezegde; vgl. ook Geb. sianiri, sianari; Pat. siniri, sinori; Makj. itanid, itanad, sinanidi, sinanadi.

De andere wijze is, dat de bezit. vnw. worden gehecht aan het partikel ${ }^{66}{ }^{66}$ ), dus : janak, anam, ina, amenamam, iterar, meunameu, sirari, en in korte vorm: nak, nam, na, namam of anamam, rār nameu en rari ${ }^{67}$ ). Deze constructie is gebruikelijk bij woorden, die spijs of drank, wenkbrauwen en enkele gereedschappen aanduiden. Ook bij woorden als bet, tuin; lilewing, groente; djiriki (het Mal. redjeki), levensonderhoud; elan, leeftocht; sus, uier; tatalè, hoen; tabako, tabak.

Een voorbeeld volgt hier van het substantief pinge, rijst:

janak pinge, mijn rijst

anam pinge, uw rijst

ina pinge, zijn rijst

amenamam pinge, onze rijst (excl.). iterar pinge, onze rijst (incl.) meunameu pinge, uw rijst sirari pinge, hun rijst

Men ziet, dat ook hier bij de vormen van de le pers. meerv. incl. en de 3 e pers. meerv. de $n$ van $n a$ in $r$ is overgegaan onder invloed van de volgende $r$.

66) De partikels $n i$ en $n a$ worden door Haaksma, o.c. p. 127 en 168 in navolging van Codrington ,possessives” genoemd (zie ook N. Adriani, De Barese sprekende Toradja's, dl. III, p. 331, 332).

67) Vg1. F. J. F. v. Hasselt, Spraakkunst der Nufoorsche taal, p. 36, jedi en jeda. 
De bezit. vnw. komen ook zelfstandig gebruikt voor en worden dan verbonden met het onbepaalde vnw. $i$, het, bijv. janiki, janaki, het is van mij, het mijne; animi, anami, het is van $u$, het uwe; ini $i$, inai, het is van hem, het zijne, hare; ise ni $i$, van wie is het?

\section{Vragende voornaamwoorden.}

Het vragende vnw. voor personen is ise, wie, welke, voor zaken ahai $\left.{ }^{68}\right)$, wat, en laisawa, hoe, hoedanig.

Ahai is samengesteld uit aha, wat en $i$, het. Dat blijkt uit peiaha, pehaha of pejasa, waarom?

Voorbeelden zijn: au re ise? gij en wie?; ise tja? wie is dat?; taie ise?, deze wie? ise ni i?, van wie is het?; ise na i?, van wie is het?; wawai tja ise ntu?, wiens kind is dat?; meoe ise?, wie uwer?; nim sapi na ise ndjagdjaga?, wie past er op uw koeien?; ise npei dab olol tja?, wie heeft die slaapmat gemaakt?; ahai tja?, wat is dat?; ampei ahai? wat doet gij?

Naar de naam van een persoon vragende bezigt men steeds ise, niet ahai, bijv. ingahnjo ise?, wie is zijn naam, hoe heet hij ?, maar: ingahnjo ahai?, wat is zijn naam, hoe heet dat? (van dieren en voorwerpen); aizeani taie ngahnjo ahai?, hoe heet dit dier?; nanai ahai ta emo na?, wat was er zo-even te zien (zichtbaar).

Ahai bijvoeglijk gebruikt betekent: wat voor een, bijv. wawai ahai tja?, wat is dat voor een kind?; ai ahai tja, wat is dat voor een boom?, wat is dat voor hout?. Laisawa, hoe, hoedanig, is samengesteld uit lai, zo, aldus, en sazwa(?). Het komt als vragend vnw. steeds aan het eind van de zin te staan, bijv. boipei laisawa?, hoe zal ik het maken?, wat zal ik doen?; mulo laisazea, hoedanig, wat is de prijs?; bodita tja ni ngale laisawa?, hoedanig, wat is de betekenis van die vermaning?; mamàglo laisawa?, hoedanig is de grootte?; menffikir laisawa?, hoe denkt ge er over?, wat denkt gijl. er van?; Djou Lahatala ntjo bobita men laisawa?, hoedanig (welk) gebod heeft de Here God u gegeven?

\section{Onbepaalde voornaamwoorden.}

Onbepaalde vnw. zijn: smat, men; smat isa, iemand, een zeker iemand; isa-isa, een ieder, elkeen; paisa, faisa, een enkele; ise, iseta, smat, iemand; smat-pa, ise-pa, niemand; okòtjesi, iets, wat; okòtjisi

68) Vgl. H. N. v. d. Tuuk, Tobasche Spraakkunst (1867), d1. II, p. 232: ise en aha. 
lālo, salemòma, alles, al wat; isa-pa, pusa-pa, faisa-pa, pus-pa pisan, niets, geen enkele, in het geheel geen; smat lälo, vele, velerlei; pon, een zekere; ponna, N.N.; $i$, het, smat dirantjá, fadirantjá, sommige, enige; smat nèsa, een ander; ise-ise, al wie; isei, al wie; farumi, dumi, alle, alles.

Bovenstaande woorden zijn voor het merendeel combinaties van woorden behorend tot verschillende woordsoorten, bijv. smat isa, lett. een mens hij één; paisa, faisa, lett. een op zichzelf; smat dirantjá, lett. mensen een deel.

Voorbeelden van gebruik: smat nfasinanga mali ulan loló, men laat braden in een pan; smat isa muti, een zeker iemand bracht het; smàte ni ebai, iemands huis; isa-isa bonāni sisim tja, een ieder, elkeen wilde het schelpdier eten; npei paisa pantò, hij maakte (deed) niets meer; mati mfabinga faisa na, maak er niet iets van bekend; gabe isa ngali ja pa, indien niet iemand mij helpt; ise-ta gabe nduk rahmate, iemand, indien hij geluk (voorspoed) heeft; jaikem smat pa, ik zie niemand; gabe ise ndarazea smat, indien iemand iemand bedriegt; ise-ta ni le ja, iemand, die mij haat; smat papisan, er is niemand; okòtjisi lālo ta ndadikan, alles, wat Hij geschapen had; Npo barakat mali okòtjisi ta ndadikan tò, Hij schonk Zijn zegen al wat Hij geschapen had; okòtjisi ta nfaeda mali smat, al wat nuttig was voor de mensen; salemòma ta mafia ni faeda, het nut van al wat mooi is; induk faise pa, hij vond niets, geen enkele; pei isa-pa, niets doen, het is niets; riri dosa pusa papisan, zij hadden geen enkele zonde; pusa fawe, nog iets; fare nduke riri pisi re mafa pusa pa, en zij hadden geen enkele ziekte of zorg; smat lālo ta dem mani, vele, die de vogel zagen; tuang ponna, de heer N.N.; ponna lalo, alles er van; mapingi lai, mani lai? mapingi, is het een man of een vrouw? het is een vrouw; latani, ulani $p a$, het is wind, geen regen; janiki, het is van mij, het mijne; ise ni $i$ ?, van wie is het?; nkurang paisa pa pisan, er ontbrak niets aan; dirantjá nfauntung smat, sommige brengen de mens voordeel aan; jaigon sapi fadirantjá, ik koop enige koeien; mpei fadirantjá, maak er enige; smat dirantjá diawa bengan, sommige vissen met een lijn; pāt kòri-kòri dirantjá, enige kleine steentjes; dirantjá du akal ta mafia, sommige noemden goede middelen; mati mfakotjitji smàte nèsa na, wil niet andere minachten; mati mfulta nim diri re smat nesa ni karadjāng na, meng uzelf niet in een andermans werk; mali smat nesa, aan anderen; gabe isa npei karadjāng pusa, indien iemand een werk verricht; bo isei nmaulangoi, opdat al wie in hem gelooft; ise-ise ndor $n d u k$, al wie vraagt, ontvangt; amekān faiumi, wij eten allen. 


\section{Betrekkelijke voornaamwoorden.}

Het enige woord, dat in het Bulisch de nauwere betrekking tussen een woord en zijn door een woord of woordgroep uitgedrukte bepaling aanwijst, is $t a$, dat in velerlei opzicht gelijkt op het Mal. jang, meer dan op het Ned. die.

Ta treedt ook wel als verzwakt demonstrativum of als lidwoord en nadrukwijzer op ${ }^{69}$ ).

Het komt ook voor verbonden met aanw. vnw. en bezit. vnw., bijv. tasine, deze; tasiá, die; fare wōl pusa wawai tasiá sinap bodjāl dodai, en op zekere dag die kinderen zij gingen naar beneden, zij wilden borden halen; fare wöl pusa wawai tasine hmā re hnjēri-si dmat, en op zekere dag deze kinderen hun ouders stierven; tariri, die hun, tasiriri, die hun; ta re ni, die met z'n, hebben; ta re na, idem, ta au, tau, die gij, ta meu, die gijl.; smat ta re riri agama biasa dtjabea, mensen, die hun godsdienst hebben, zij zijn gewoon te bidden; padamara ta re ni sibu pa, lampen, die geen lampenkous hebben; ta tina tó, dat gereed, af zijnde $=$ vervolgens, daarna.

Ook wordt het verbonden met substantieven, meestal gevolgd door het onbep. vnw. $i$, bijv. ta mani, die het is een man, jakbuk ta mani, mijn grootvader, mijn kleinzoon; jakbuk ta mapingi, mijn grootvader, mijn kleindochter; ta mapingi, die het is een vrouw, of met bijwoorden, bijv. ta tuba, die voorheen, vroeger waren; ta $p \bar{a} p$, die beneden zijn.

$\mathrm{Na}$ het betr. vnw. $t a$ wordt bij de vervoegde vormen steeds de korte vorm van het pers. vnw. gebruikt, bijv. ja ta iduki, ik, die ik vond het; pāt-jī ta npopolulu, een slijpsteen, die rond is; ja taine Djou ta isapnga $m e u$, Ik de Heer, die Ik ulieden er uitgebracht heb; gabe wōl ta ntja sema tò, indien de zon die gaat op, het is al ochtend (dag).

Voorbeelden van het gebruik van ta zijn: ai ailu ta mali bet fapaluno tasine, de twee bomen, die in het midden van deze tuin zijn; smat ta nafetang taine, de mens, die dit vertelde; nanai ahai ta emo na?, zo-even wat dat zichtbaar was?, wat was zo-even zichtbaar?; okòtjesi lālo ta ndadikan, alles, wat $\mathrm{Hij}$ geschapen heeft; ise ta ni le ja, wie, die zijn haat, mij ?, wie hij haat mij ?; pnu ta ndadi kóro meu, het land, waarin gijl. slaaf waart; agagaum ta mdom na, uw plaats, waar gij drinkt; kolano ta wōl tja o $i$ re kolano ta wōl tjop o $i$, de koning in het Oosten en de koning in het Westen; fare okòtjisi ta mtā ja läl, mai nemem pa,

69) Vg1. C. A. van Ophuysen, o.c. p. 162, 163 en p. 306 vv., N. Adriani, Spraakkunst der Barese taal, § 237 en S. J. Esser, Klank- en Vormleer v. h. Morisch, p. 161 vv. 
vervolgens is er wat veel ogen heeft, maar het ziet niet; ise ta nem ebai ta ni rupa laina?, wie, die zag het huis, dat zodanige vorm heeft ?; gabe smat ta riri ebai na, indien de mensen, wier huis dat is; smat ta gitjori gogó, mensen, wier huid zwart is ; salang ta wōl tja bere mtā bená, zelfs de zon, die heeft ook nog een oog; maping tja nlònga ta mān tja nu laina, de vrouw hoorde, dat de man aldus sprak; taun ta dboboi taie, het jaar, dat zij voor zich hebben, het komende jaar ; tilibo ta nakakrung, de trom, die gaf geluid; jaitō pa ta au taine, ik ' $\mathrm{k}$ wist niet die gij hier, ik wist niet, dat gij hier waart; nik pnu ta las pa na, mijn dorp, dat niet dichtbij (= ver) is; ga, ahai ta lio tai?, wel, welk geluid is dit?; aiwani ta mamàglo laina na, een dier, welks grootte aldus is; ai lālo ta pio ja mna re mismis na, allerlei bomen, wier vruchten lekker en zoet zijn; parakara pusa ta majana leo, een zaak, die zeer licht is; isa pa ta bonpei laina, niemand, die het aldus kon maken; ta ni cbai tja, die, wiens huis het is; mani lālo ta re faio, alle vogels die met hun vleugels (= hebben vleugels); Amchmāmam ta imali gagau awal kakal, Onze Vader, die in de hemel zijt; waja ta puis re ta pāp tai, water, dat boven en dat beneden is; dangkis ta lālo ta mali dunia $i$, dieren, die velerlei zijn, die in de wereld zijn; okòtjisi ta lālo taine, alles, dat velerlei is hier; smat ta re slubo dfaroro fable tja, mensen, die bij honderden waren, zij keken naar dat spel; pāt ta pu, het Westen dat voetstuk, z'n voetstuk (= de Westelijke horizon); morla ta $p u$, het Oosten dat voetstuk, z'n voetstuk (= de Oostelijke horizon); smat ta tuba, mensen, die vroeger waren (voorouders); ta naplangan tja nfangahnjo sema, dat het was licht $\mathrm{Hij}$ noemde. dag; ta dòròram tja ngahnjo dòram, dat donker was, zijn naam was nacht; sema tja ta wōl pifát, de morgen, die dag vier (= het was morgen, de vierde dag); alam ta mlàngo re mamàglo taie, deze aarde, die haar lengte en grootte; mali tapak ta mlàngo tja làpo tiná, aan de hele lengte van de wegrand; tiná majai ta majai, dat slecht, het slecht (= het allerslechtste).

Verder komt $t a$ voor in zinnen als deze: ta sema lele $i$ be ulan denabé taine, van de vroege ochtend tot nu heeft het geregend; ta umur smat ndela pa, gedurende het gehele leven gelooft men hem niet; ta itub mali be denabé taine, zolang als ik geleefd heb tot nu toe. 
HOOFDSTUK V.

$\mathrm{Het}$ we rkwoord.

Tot deze woordsoort behoren $1^{\circ}$ grondwoorden en combinaties van grondwoorden, $2^{\circ}$ geredupliceerde grondwoorden, $3^{\circ}$ grondwoorden voorzien van bepaalde prefixen, $4^{\circ}$ grondwoorden van bepaalde suffixen voorzien. $Z \mathrm{ij}$ hebben met elkaar gemeen, dat zij met de persoonlijke voornaamwoorden onscheidbaar verbonden kunnen worden ${ }^{70}$ ).

\section{Grondwoorden en combinaties van grondwoorden.}

De werkwoorden, die tot deze groep behoren, zijn zowel intransitief als transitief. Voorbeelden zijn: opa, vliegen; osal, staan; fān, lopen, gaan; totoláng, zitten; te, zitten (v.e. vogel); sung, naar binnen gaan; sapang, naar buiten gaan; seli, eten; sa, opgaan (v. zon en maan); sop, ondergaan (v. zon en maan); jas, zwemmen; teka, opschrikken; arir, springen; doas, afvallen, uitvallen; iawa, zoeken; $d u k$, vinden; $p o$, geven; em, zien; $j \bar{a} l$, nemen, halen; ut, brengen; sisop, baden; uas, wassen; pun, doden.

Voorbeelden van gebruik in zinnen zijn: fare nfän niawa tanmjangis tja, denabé nduki, vervolgens hij ging, hij zocht wat verloren was, totdat hij het vond; fare nem matjang isa, vervolgens zag hij een tijger; kabil wawaio tja nlònga smat nparo pota bawa tja, de jonge feit (het kind van de geit) hoorde iemand kloppen vóór de deur; tuka tja n-jäl ni eta $n a$, de timmerman nam (haalde) zijn kapmes; mali wōl taie mpo namam djiriki ntotim, op deze dag (heden) geef ons levensonderhoud, dat voldoende is; nok tja nuta ntutá na än, de aap bracht het eten van zijn kind; maping tja ntjisop ntu tja, de vrouw baadde haar kind; ise npun

70) Woorden, die weliswaar in de Nederlandse vertaling vaak met een werkwoord zullen worden weergegeven, blijken doordat zij met de bezittelijke voornaamwoorden verbonden worden, in het Bulisch niet als werkwoorden beschouwd te worden, maar als substantiva. Hiertoe behoren een aantal woorden die een gevoel of een richting aanduiden, zo bijv. ulo loló, houden van; le, haten; ulo neto, zich herinneren; ulo ja mitji, hartzeer hebben; ulo ja mtu, een hard hart hebben; ulo, willen, wensen; ulo ja mafia, een goed hart hebben; ulo ja mòmòfia, verheugd zijn v. hart, zich verblijden; glao ja māng, de droge keel, d.w.z. dorst hebben; nafsu, begeren, begeerte; lalau, malau, zeewaarts gaan; polau, aan zee zijn; lali . daarheen gaan; malī, hierheen komen; lalei, naar de landzijde gaan; polei, aan de landzijde zijn; nais, opwaarts gaan. Wel krijgen deze richting aanduidende woorden een pers. vnw. vóór zich, doch steeds in de zelfstandige vorm, bijv. ja lalau, ik zeewaarts; ou malī, gij hierheen, herwaarts; $i$ polou, hij aan de zeezijde; it lali, wij (incl.) daarheen; ame mali, wij (excl.) herwaarts; man polei, gijl. aan de landzijde; si nais, zijl. opwaarts. 
au?, wie heeft $\mathrm{u}$ gedood?; wawai tja nān ian re pira, het kind eet vis en sagoe.

Tot deze eerste groep behoren ook een aantal, die ook als adjectief kunnen optreden, bijv. pisi, ziek, ziek zijn; mat, dood, dood zijn; gagli, mager, mager zijn; bofbof, vet, vet zijn; nenèna, klein zijn; mamàgal, groot, groot zijn; kangela, vermoeid, vermoeid zijn; bili, zacht en week, zacht en week zijn (v.e. vis); gagalúm, zacht en week, zacht en week zijn; mara, rijp, rijp zijn; masa, gaar, gaar zijn.

Enige voorbeelden in zinnen zijn: jaikowil, ik heb koorts; jahmak npisi ntebteb, mijn vader is zwaar ziek; luf tja nmat, die muis is dood; titimin nmara $t u$, een komkommer, zij is zeer rijp; titimin ngagalum $t u$, een komkommer, zij is zeer zacht; ian tja nbili tò, die vis is al week (bedorven); fun tja ngagli, die hond is mager; aiwani isa nmamàgal tu, een dier het is zeer groot.

Anderen komen ook voor als substantief, bijv. ān, spijs, eten; falai, zeil, zeilen ; del, metgezel, volgen ; mafngel, droom, dromen; akal, list, bedriegen; lalau, geneesmiddel, een geneesmiddel gebruiken, iem. een geneesmiddel geven.

Enige gevallen vindt men in de volgende zin : fare luftá ntjesela, pòna ugamta ntongaloló, taga salilitá nfamula, vervolgens de muis, hij ,,voorstevent”, dan het schelpdier, het ,midscheept”, en dan de rode boommier, hij ,achterstevent”, d.w.z. de muis was op de voorsteven, het schelpdier midscheeps, en dan de rode boommier op de achtersteven.

Voorts kan men tot deze eerste groep van werkwoorden rekenen combinaties van grondwoorden als: $j \bar{a} l$ salo, damar halen, verzamelen; $j \bar{a} l$ bantung, hulp halen; $j \bar{a} l$ ian, vis halen, vangen; $j \bar{a} l$ săl, fouten maken; jāl boboko, hoofden halen, koppensnellen; pei māngi, lawaai maken; pei bet, tuinieren; pei pelang, ,scheepmaken”; pei liau, rumoer maken; pei suwang, djini maken, de suwvang vereren (d.i. een feest maken, waarbij door een medium (shamaan) de geleidegeest wordt opgeroepen en geraadpleegd); pei pata, herhalen; pei walit, verzen maken, voordragen; pei ān, eten bereiden; pei ian, vis bereiden; pei sāl, misdrijven, overtreden; pei smo, tandenvijlen; pei wo, sagoweer tappen; pei tafal, tekenen; pei lio, geluid maken, geven; pei rame, plezier maken; pei salo, damar aftappen.

\section{Geredupliceerde grondwoorden.}

De tweede groep van werkwoorden bestaat uit geredupliceerde of geheel verdubbelde grondwoorden met verbale betekenis. Deze geredupliceerde of verdubbelde werkwoorden betekenen een herhaling of een 
voortduren dan wel een versterking van de verbale betekenis van het grondwoord. Voorbeelden zijn: van fonla, eindigen, ophouden met, fonfonla, geheel eindigen, totaal ophouden ; van dirak, verhuizen, didirak, telkens weer verhuizen; van $t \bar{o}$, weten, $t \bar{o}-t \bar{o}$, terdege weten; van tuwaf, vouwen, tutuwaf, herhaaldelijk vouwen (bijv. dab tutuwaf, een meermalen opgevouwen mat); van sali, scheppen, roeien, salsali, voortdurend scheppen, roeien; van $\bar{a} n$, eten, $\bar{a} n \bar{a} n$, aldoor eten; van em, zien, emem, voortdurend zien; van salawe, losmaken, sasalawe, aldoor losmaken; van bubit, uittrekken, bububit, aldoor uittrekken; van popat, schelden, popopat, herhaaldelijk schelden; van tole, boos zijn, totole, voortdurend of heel boos zijn; van ningo, kijken naar, ningningo, staren, voortdurend kijken naar; van pun, slaan, doden, punpun, mishandelen; van derér, volgen, dererér, onophoudelijk volgen; van lebat, een vaartuig sturen met een roeiriem, leblebta, wrikken; van pei, doen, maken, peipei, aldoor doen, maken.

Voorbeelden in zinnen zijn: smat nbolbòlo mdumi garedja, men gaat allen tezamen naar de kerk; fare dtjältjali lalei nagá, vervolgens zij roeiden maar aldoor landwaarts ; npeipei walit, hij maakte maar aldoor gezang; mān tja npunpun kòro tja, de man mishandelde de slaaf; fare nbububit tortor tja faio na, en hij trok de kapel aldoor de vleugels uit; wōl pusa wōl pusa isasalawe njawa aizvani, iedere dag maak ik los (dood ik) het leven van dieren.

Van sommige verbale grondwoorden komen de geredupliceerde of gegemineerde werkwoorden niet voor, hetgeen voortvloeit uit de aard der betekenis van deze grondwoorden. Zo bijv.: fānfān, wandelen; totoláng, zitten; ararir, springen; kakalat, klokken; purpurar, drijven ; lalaman, loloman, wachten ; tengtengan, zwijgen ; dibdib, kaatsen ; bukbuk, schuimen; tagtaga, nazetten, achtervolgen; sausawal, zweven; opopa, vliegen; ngangala, zich bewegen; ututa, denken, overleggen; teteam, blijven; daodao, raden; leplep, lekken.

Voorbeelden in zinnen zijn: mteteam mantā tò, blijf steeds hier!; fare ntjausawal puis dunia taie, en hij zweefde boven deze aarde; fare nfānfān lalei, zij gingen (liepen) aldoor landwaarts; wōl pusa wōl pusa nfānfān mali bet tja loló, iedere dag wandelde zij in de tuin; fare wawai tja hmā re hnjēri si dtagtaga nganga tja, vervolgens de ouders van het kind, zij achtervolgden de uil; dangkis ta lālo ta dopopa, allerlei dieren, die aldoor vliegen, d.w.z. vogels ; nloloman i manā na mnu tu, hij wachtte hem daar zeer lang.

Slechts één geval is ons bekend, dat een werkwoord gevormd wordt door reduplicatie van een adjectief met de betekenis van een doen, zich 
gedragen als nl. van biaf, blind, bibiaf, als een blinde doen, zich gedragen, rondtasten als een blinde.

\section{Combinaties van grondwoorden en voorvoegsels, met verbale betekenis.}

A. Grondwoorden met de prefixen ma-, am-, m-, $a$ - en mara-.

Er komen in het Bulisch een aantal werkwoordsvormen voor welke bestaan uit grondwoorden van diverse betekenis, gecombineerd met de prefixen ma-, am-, $m$-, $a$ - en mara-. Het was ons niet mogelijk vast te stellen in welke gevallen het ene prefix optrad en wanneer het andere en bij welke groepen van grondwoorden deze prefixen voorkomen. $\mathrm{Er}$ lijkt reden te zijn om de prefixen $m a$-, $a m$ - en $a$ - te zien als vormen van éénzelfde prefix, hoewel er in een enkel geval wel een grondwoord voorkomt, dat met het prefix ma- èn met het prefix am-gecombineerd wordt met duidelijk verschil van betekenis, bijv. amlif, lachen, malif, lachebek; amtjait, vrezen, matjait, bangerd. Geen van deze prefixen lijkt productief te zijn.

De werkwoorden met het prefix am- / ma- / m- komen voor met grondwoorden met adjectivische, verbale en substantivische betekenis. Soms ook komt het grondwoord alleen voor in combinatie met affixen.

Voorbeelden zijn : amtuli ${ }^{\mathbf{7 1}}$ ), slapen, waarnaast matuli, slaapkop, domkop, staat, dat waarschijnlijk hetzelfde grondwoord bevat; amlif ${ }^{72}$ ), lachen; amolol, ronddraaien; amduri, zinken, van duri, afdalen, zakken; amtjait, vrezen, van tjait, vrees; amderèrér, beven, sidderen, van derér, volgen; amnutup ${ }^{73}$ ), verdrinken, van utup, een bamboe in de rivier met water vullen; masese, masise ${ }^{74}$ ), bedwelmen, van sese, sise?; masie, medelijden hebben, zich erbarmen over, van sie, medelijden, erbarmen; amewis, vergaan van een vaartuig, van ewis, bederven, vernielen; amngai, uit weerwolven gaan, van ngai, weerwolven; masiusereril, hikken, de hik hebben, van siuserwil, schommel (?), ook s.v. vampyr (?); amdoas, afvallen van bladeren, uitvallen van tanden, van doas, afvallen; amgini, in brand staan, van gini, branden; maatang, voorgezet, opgedist zijn, van atang, zichtbaar (?); malòngna ${ }^{75}$ ), horen, luisteren naar; van

71) Vgl. Bar. turu, Mor. turi, diverse Philippijnse talen: tulug.

72) Vgl. Sangir lege, Bar. gele.

73) Deze $n$ tussen het prefix en het grondwoord kan ik niet verklaren.

74) Dhr. A. K. Bot deelde mij mede, dat masise speciaal „bedwelmen door sirih-pinang" betekent.

i5) Dit woord heeft het suffix $-a$ en daarvóór een mij onverklaarbare $n$; deze $n$ komt ook voor in aslòngna of ahlòngna, verspieden, uithoren, indien tenminste 
lònga, horen; mabuli, Bulisch spreken; mamalaju, Maleis spreken ${ }^{76}$ ). Voorbeelden in zinnen zijn: inamtuli paube, hij slaapt nog niet; mati mamlif ná, wil niet lachen, lach niet!; padati ni roda mamolol, de wielen van de kar draaien rond; pelang tja namewis, die prau slaat uit elkaar, vergaat; fare damderèrér dlònga kolano tja lio na, en zij sidderden, (toen) zij hoorden de stem van de koning; mati mamtjait ja ná, vrees mij niet, wil mij niet vrezen; jaikamtjait gu, ik vrees slangen; tuang ni pelang tja namduri tò, de prauw van mijn heer is gezonken; mmasie ja, heb medelijden met mij!; ja taine imasie au tu, ik, ik heb veel medelijden met je; paliu tja nmasese $j a$, die pinang bedwelmt me; fare tamaga na nmasise $i$, vervolgens de sirih-pinang bedwelmde hem; ite wazrai tmalòngna parenta $h m \bar{a}$ o re hnje $o$, wij kinderen, wij luisterden naar, gehoorzamen aan de bevelen van vader en moeder (de ouders); popei kurunga silú damgini, gisterenavond verbrandden twee schuren, zijn twee schuren verbrand; fare namlif gabe nawit lolas tja, en hij lachtte, indien hij de berg beklom; fare ni pelang tja namerwis fare inamnutup, vervolgens zijn vaartuig verging en hij verdronk;

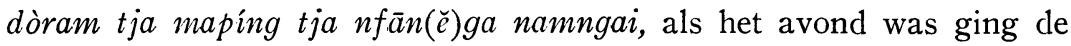
vrouw maar zij weerwolfde (ging uit weerwolven); jaizealanda iduk $p a$, ik kan geen Hollands spreken.

De vormen met het prefix $a$ - kwamen reeds ter sprake bij het adjectief. Daar zij steeds vervoegd kunnen worden zijn zij echter eveneens tot de verba te rekenen.

Met $a$ - worden gevormd werkwoorden, die een quantiteit of qualiteit aanduiden ${ }^{77}$ ), bijv. van las, nabij, alas, nabij zijn; van lau, ver, alau, ver zijn; van marea, ruim, amarea, ruim zijn; van $l a \bar{l}$, veel, aläl, veel zijn; van $m \bar{a} n g$, droog, amāng, droog zijn.

Enige voorbeelden in zinnen zijn: fare matjang isa nalas manā, en er was een tijger daar dichtbij; leg tja nalau re dòròram, het hol was ver (diep) en donker; jawane ni wa naläl, de wortels van de waringin zijn veel; wöl tja nalau tu tò, de zon is al zeer ver, staat al heel hoog; waja ta mali talaga tja namāng, het water in de vijver (poel) was droog; bet tja namawa $t u$, die tuin is zeer ruim.

Men treft eveneens een groep werkwoorden met het prefix $a$ - aan,

van deze werkwoorden ook het grondwoord lònga is. Zo ook ongna, bijten in, van ong, bijten. Mogelijk is deze $n$ een oude sluiter, vgl. H. Kern, De Fidji-taal enz., p. 72.

76) Vgl. N. Adriani, Spraakkunst der Barese-taal, p. 146, het prefix mo-; S. J. Esser, Klank- en Vormleer van het Morisch II, p. 324, het prefix -mompe-.

77) Vgl. S. J. Esser, o.c. p. 348. 
welke betekenen het maken van het geluid, dat het grondwoord aanduidt, bijv. van fum, het geluid, dat een vlieger of een vliegende jaarvogel maakt, afúm, het geluid fum maken; van tjing, klinkend als porseleinen borden, atjing, het geluid tjing geven; van bluk, wapperend geluid v. e. vlag bijv., ablik , wapperen van vlag of zeil; van kakrung, het geluid van een trommel, akakrung, trommelgeluid geven; van $t j u f$, het sissend geluid van gloeiend ijzer in water, atjuff, sissen; van hngor, het snorkend, knorrend geluid van een varken, ahngór, snorken, knorren.

Enige voorbeelden in zinnen zijn: liliànga tja nafúm, die vlieger maakt het geluid fum; piring tja natjing, het bord klinkt; talibo tja nakakrung, de tifa geeft het geluid kakrung; besi tja natjúf, het ijzer sist; bou tja nahngór, het varken knort, snorkt; jaikaús, ik maak het geluid $u s$, ik beblaas.

Verder treft men onder de $a$ - vormen verba van diverse aard aan, bijv. abulat, ronddraaien, van bulat, rond (Mal.), bijv. jaikabulat pātjī tja, ik draai de slijpsteen rond; kapal ni roda tja nabulat, de schroef van het schip draait rond; agua, weerwolf zijn, worden, van gua, weerwolf, bijv. ostane män tja nagua, zeker die man hij werd weerwolf; aplangan, licht geven, van plangan, licht, bijv. padamara tja ni loblob naplangan, de vlam van de lamp geeft licht, verlicht; arér, volgen, van rer, volgen, bijv. pelang tja narér mumat, de prauw volgt de branding; atjutje, stoten tegen, met, van tjut, stoten, bijv. jaikatjutje ${ }^{78}$ ) fitjok mali pāt tandahle loan tja, ik stootte met mijn voet tegen een steen, die dichtbij de trap was; afula, een lijn of touw draaien met de hand, van fula, lijn door timmerlieden gebruikt.

In enkele gevallen komt het mij voor, dat de vormen met het prefix $a$ - ongeveer gelijke betekenis hebben als vormen met het prefix $f a$, bijv. asisira, een vogel strikken, van sisira, vogelstrik, bijv. taie kasturi to ikasisira $i$, dit is de kasturi (s.v. papagaai), die ik strikte hem, (die ik gestrikt hem); atula ${ }^{79}$ ), slaan met de rug van een kapmes, van $t u l$, tulo, rug van een kapmes.

De werkwoorden bestaand uit een vaak verbaal grondwoord en het prefix mara- ${ }^{80}$ ) zijn weliswaar, evenals de werkwoorden met $a$ - en

${ }^{78)}$ In atjutje treft men het suffix $-e$ aan.

79) In atula treedt het suffix $-a$ op.

*0) Zie N. Adriani, De Barese sprekende Toradja's, III, p. 324, 325. Waarschijnlijk is mara gelijk te stellen aan het Filippijnse mag, Tomb. mah, dat in het algemeen een worden aanduidt en intransitief-passieve betekenis heeft. De vorm mar zou dan misschien tot mara uitgebreid zijn. Zie over mara ook Jonker,

Verh. dl. X. 
$m a-$ / am- / $m$ - intransitiva, maar zij verschillen toch van hen in betekenis. $Z_{\mathrm{ij}}$ betekenen ongeveer hetzelfde als in het Ned. de combinatie van het werkwoord ,zijn” met een participium passivum.

Soms komen van hetzelfde grondwoord vormen met het prefix $m a-/ a m-/ m$ - en het prefix mara- voor; in die gevallen blijkt het betekenisverschil duidelijk, bijv. van ewis, vernielen bijv. bomati nik sapi na dereris anam bet tiná na!, opdat mijn koeien uw tuin niet vernielen!; maraewis, uit elkaar vallen (v. e. prauw door ouderdom), bijv. tuan ni pelang tja nmaraezis( $\breve{e})$ tò, de prauw van mijnheer is al uit elkaar gevallen, tegenover: mezris, amezis, vergaan (op de klippen) bijv. fare kapal tja namereis, en dat schip verging.

Men vergelijke ook nog de volgende zinnen: fare ntjalawe $n d u k p a$, en hij maakte zich los, hij kon niet; msalawe bawa kamal tja, open de kamerdeur; fare matjang tja nmasalawe, en de tijger hij was bevrijd; barwa tja nmasalawe tò, de deur staat open; nanai jaimarafsis, zoëven kwam ik uit te glijden; sababe nfarera ja amtoal tu, fare ntjutje $i$ mali pāt isa $i$ mali tapak tja fapaluno fare nmapakpak nap, omdat hij zeer hard liep, stootte hij zich tegen een steen, die op het midden van de weg lag en kwam voorover op zijn buik te vallen (te liggen).

Voorbeelden van werkwoorden met mara- zijn: marapazirl, af vallen van zelf, bijv. van een dode tak, komen te vallen, van parvil, zich laten vallen; marawogal, in stukken gebroken, van wogal, breken; marasegal, uit zich zelf gespleten zijn, van segal, splijten; marapas, gespleten zijn, zoals de hoef van een varken, van pas, splijten; marapes, gebroken, stukgeslagen, van vaatwerk e.d., van pes, slaan; marakati, afgesneden, afgebroken, van kati, afsnijden; marasekan, afgescheurd, gescheurd zijn, door ouderdom, bijv. van sekan, scheuren; marasibit, uitgetrokken zijn, van gras bijv., van sibit, uittrekken; marabuak, overgekookt, door gisting overgelopen zijn,zoals sagoweer, van buak, overkoken, overlopen; marasira, uitgetrokken, gespannen zijn, van ijzerdraad of touw, van sira, uittrekken, bijv. een lade uit een kast of tafel ; maratép, geschonden zijn, bijv. van een kapmes, dat hakscharen heeft, van tep?; marafrorang, weggezakt zijn, van frorang, wegzakken met de voeten; maradilang, uitgepuild zijn, van dilang, uitpuilen, door persing bijv.; marasiap, afgeschilferd, schuins afgebroken zijn, van siap, afschilferen, schuins afbreken; marafsis, uitgegleden zijn, van rafsis, uitglijden; maralapis, van zijn plaats geraakt, verleden, reeds geschied; van lapis, los, vrij,

Bijdr. Kon. Inst. 63 (1911), p. 217, 298 en Adriani, Spraakkunst van het Barese, p. $238 \mathrm{vv.}$ 
voorbij; marasupat, losgeraakt zijn, van een touw, van supat, los; maraforas, geheel gevuld, rond, dik zijn tot berstens toe, van poras, rond, dik; marapurus, van een gat of gaten voorzien zijn, van purus, gat ${ }^{81}$ ); marapu, met wortels en al omgevallen zijn, van een boom bijv., van $p u$, wortelstuk van een boomstam, voetstuk; marasazea, van elkaar gescheiden, met een kier of scheur zijn, van sawa, spleet, kier, scheur.

Verdere voorbeelden in zinnen zijn: obat taine marasekan ndumi, deze sarongs zijn alle gescheurd; kapal taie nmaralapis tuan tja npea nap Ake-lamo, als de boot voorbij is, gaat mijnheer naar Ake-lamo (in het Noorden van Buli); garedja tan maralapis tja jaimabuli majai sube, toen er de laatste keer kerk was, heb ik nog weer slecht Bulisch gesproken; wōl sabtu tanmaralapis tja, verleden Zaterdag; anim padati ni eri na marawogal( $\breve{e}) t o ̀$, de as van uw kar is in stukken gebroken; janik pät tulis nmarapes( $\breve{e})$ tò, mijn lei is reeds gebroken; gabetá aizwani silú tasiá dmarapazil nap reaja loló, diensvolgens kwamen die beide dieren naar beneden in het water te vallen; làse bonmarapazcil, bijna zou hij zijn komen te vallen; fare mumat tja malei njalo fare nmarapu, en de branding kwam landwaarts en nam er van, vervolgens kwam hij te vallen; osetane djou tja nem okòtje marasawa bontolé, zekerlijk de heer ziet een weinig gespleten, hij zal boos zijn; fafan tja nmarasiap, die plank is schuin afgebroken; na gendi tja nmarapes, haar waterkruik is gebroken; bawa tja nmaraparír, de deur staat open; bawa tja nmarasira, de deur staat open, is opengeschoven; iā tja nmaraepo musala popó, de saus is gestort (gemorst) op de mat; bang tjutjuping na itetmarapaulo parakara ta nenèna, soms (een enkele keer) wij komen te vallen over dingen, die klein zijn; fare hnjao tja nmaraporas, fare nmat, en zijn buik kwam te bersten en hij was dood.

B. Grondwoorden met het prefix fa-.

Het prefix $f a$ - of $a f$-, dat ook reeds ter sprake is gekomen bij verschillende andere woordsoorten, nl. de substantieven, de adjectieven en de telwoorden, speelt ook bij het werkwoord een belangrijke rol.

Wat de vorming aangaat, slechts in één geval ondergaat de vorm van het grondwoord bij aanhechting van het prefix verandering. Begint een grondwoord met een $d$, dan gaat deze bij voorvoeging van $f a$ - over in $r$, bijv. van dom, drinken, faròma, te drinken geven, drenken; van ding, naaien, faringo, naaien met, van derér, volgen, farerér, doen

81) Het komt ook voor als substantief: guguo ni marapurus, neusgat. 
volgen; van duping, ontmoeten, farupngo, ontmoeten met, samentreffen met.

Of er enige regelmaat schuilt in het optreden van $f a$ - of $a f$ - konden wij niet vaststellen. Soms gaat dit prefix gepaard met de achtervoegsels $-o,-a$ of $-e$, zonder dat dit betekenisverschil schijnt te veroorzaken. In sommige, hieronder nog te noemen gevallen wordt het prefix gecombineerd met het geredupliceerde grondwoord.

Verbonden met grondwoorden met adjectivische betekenis vormt het werkwoorden met causatieve betekenis, bijv. van maof, tam, famaof, temmen; van tjait, bang, fatjait, bang maken; van mare, ruim, famare, verruimen; van $s \bar{a} l$, fout, mis, fasăl, schuldig verklaren, straffen; van tjòtjòma, troebel, fatjòtjòma, troebel maken; van majai, slecht, famajai, slecht maken; bederven; van gai, moe, fagai, vermoeien; van bersi (= Mal. berrsih), fabersi, schoonmaken; van mat, dood, famat, doden.

Ook met enkele grondwoorden met verbale betekenis worden $f a-$ causatieven gevormd, bijv. van paling, oplichten, opstaan, fapaling, overeind zetten; van totfa, kleren wassen, fatotfa, kleren laten wassen, opdragen om kleren te wassen; van $\mathrm{em}$, zien, faem, laten zien, doen zien; van jaling, drijven, fajaling, doen drijven; van tenga, stil zijn, fatenga, laten blijven zoals het is, met rust laten; van sus, zuigen, fasus, zogen, laten zuigen; van jangis, weg, verdwijnen, fajangis, doen verdwijnen, wegmaken; van amduri, zinken, gezonken, famduri, laten zinken; van $t u b$, leven, fatub, laten leven, in het leven behouden.

Voorbeelden in zinnen zijn: mati mfamajai smat nenèna ná, wil niet de kleine (geringe) mensen verachten, slecht maken; amfatjòtjòmā waja tja, gij hebt het water troebel gemaakt; habar taie nfasenga am, dit bericht verheugt ons, maakt ons blij; waga tja jaifadodano rupia pusa, die cocospalm verpand ik voor één gulden; bonfajangis djame ngingai $n a$, hij wilde laten verdwijnen, wegmaken de bittere smaak; mfatub $j a$, laat (houd) mij in het leven; zeelisá ai mnuo taie ifatenga $i$ be tò, het is goed deze oude boom, ik laat hem nog maar met rust (ik laat hem maar staan).

Met grondwoorden met substantivische betekenis vormt het prefix $f a-/ a f$ - werkwoorden, die betekenen: gebruik maken van, zich bezig houden met hetgeen door het grondwoord wordt aangeduid, bijv. van mailufi, s.v. vishengel, famailufi, met zulk een hengel vissen; van kula, handschoffel, fakula, met zulk een handschoffel werken, schoffelen; van rau-rau, s.v. giftige boomwortel, farau-rau, met rau-rau vissen; van djala, net (= Mal. djala), fadjala, met een djala vissen; van lalau, geneesmiddel, falalau, geneesmiddelen gebruiken, aanwenden; van sub- 
sub, s.v. vlindernet, garnalennet, fasub-sub, met zulk een net vlinders of garnalen vangen ${ }^{82}$ ); van guman, tol, faguman, tollen; van $u b i$, cocosschaal, faubi, met cocosschalen spelen (s.v. spel); van dingding, kinderwiegeliedje, fadingding, kinder-wiegeliedjes zingen; van darawa, leugen, liegen, fadarazea, leugens voortbrengen, liegen; van rano, grens, farano, een grens stellen; van utan, vraag, vragen, fautan, vragen stellen; van sula, bevel, fasula, bevelen geven; van kubele, hanespoor, fakubele, vechten van hanen; van bet, tuin, fabet, tuinieren; van djame, smaak, fadjame, proeven; van wàngat, (vrucht)vlees, fawàngat, vruchtvlees uit cocosnoten halen; van biboing, rouwklacht, fabiboing, rouwklachten aanheffen; van jataf, atap, fajatfo, met atap dekken; van kakalat, klokgeluid van water, fakakalat, doen klokken (van water in een cocosnoot); van dodano, pand (dat waarschijnlijk het grondwoord dano bevat), fadodano, verpanden; van ngasan, naam, fangasan, een naam geven; van seli, niesgeluid (?), afseli, niesgeluid maken, niezen; afnet, van een bruggetje gebruik maken, van tet, bruggetje (met wijziging van het grondwoord); van $t u b$, leven, fatub, laten leven; van talak, scheiding, fatalak, echtscheiden.

Voorbeelden van gebruik in zinnen zijn: ise nfasula mpeio bet na jajā, wie gaf bevel gij maakt een heg om uw tuin?; gabe smat ta noi-fun tja nfautan: kamasefa tau, an mantjazea?, indien de jager de vraag stelde: kamasefa, die gij, waar zijt gij ?; ntō tò farea nfautan fawe, hij weet (het) al en hij stelt weer vragen; mali itetfān bodfasubsub, komt laten wij gaan, opdat wij garnalen scheppen, (vlinders vangen).

In de derde plaats wordt het prefix $f a$ - gecombineerd met grondwoorden met verbale betekenis. De werkwoorden die uit deze combinatie ontstaan hebben meervoudige, reciproque, dan wel intensieve betekenis. Vaak wordt het geredupliceerde grondwoord met $f a-$ gecombineerd.

Voorbeelden van werkwoorden met meervoudige betekenis zijn: van gogoro, uitnodigen, fagogoro, tezamen uitnodigen tot een feest; van $j \bar{a} l$, halen, fajāljāl, met elkander samen brengen, halen (v.e. bruidspaar); van $p a$, aan een stok op de schouder dragen, fapapa, samen aan een stok op de schouders dragen ( $p i k u l)$; van derér, volgen, farerér, iets tegelijk, gezamenlijk doen; van sake, strooien, zaaien, fasaksake, van elkander verwijderen.

Voorbeelden van werkwoorden met reciproque betekenis zijn: van

82) Vg1. N. Adriani, Spraakkunstige Schets v. d. taal der Mentawei-eilanden, p. 66 , noot 1 . 
$d u k$, vinden, fadukduk, elkaar vinden; van duping, ontmoeten, aantreffen, fadupduping, elkaar ontmoeten, aantreffen; van em, zien, faemen, elkaar zien; van pun, slaan, doden, fapunpun, elkaar slaan, mishandelen; van tota, hakken, fatotota, op elkaar inhakken; van ololau, roepen, faololau, elkaar roepen; van izean, verwisselen, faiwan, elkaar afwisselen; van kotalē, twisten, fakotalē, met elkaar twisten; van ulo-loló, houden van, faulo-loló, van elkaar houden; van otjé, geven, faotjéotjé, elkaar geven; van utan, vragen, faututan, elkaar vragen; van fugal, worstelen, fafugal, met elkaar worstelen; van gōp, omhelzen; fagōpgōp, elkaar omhelzen; van popat, schelden, fapopopat, elkaar schelden; van agel, bijten, fagel, elkaar bijten.

Voorbeelden in zinnen zijn: fare fun silú tasiá dfagel, en die beide honden beten elkaar; dfaututan ise bonbarani, zij stelden elkaar de vraag, wie er de moed zou hebben; fare wawai silú tasiá dfakotalēe, vervolgens die beide kinderen twisten met elkaar; fare dfapunpun, en zij sloegen elkaar; denabé sidfakotjubu, totdat zij elkaar stompten; mati ffasigsigo na, wilt elkaar niet berispen, becritiseren.

Voorbeelden van werkwoorden met het prefix $f a$ - met intensieve betekenis zijn: van kiko, ombinden, omsnoeren, fakiko, afbinden; van pangan, de mond wijd openen, fapangan, gapen, geeuwen; van taif, begrijpen, fataiftaifo, terdege, volkomen begrijpen; van $t \bar{o}$, weten, kennen, fatōtō, terdege weten ; van $d o$, zien, kijken, faroro, terdege bekijken ; van fasapang, naar buiten doen gaan, caus. van sapang, naar buiten, uitgaan, fafasapang, met kracht, sterk naar buiten doen gaan; van bitjim, vasthouden, bijv. v.e. paal, die overeind gezet wordt, fabitjim, iets stevig vasthouden; van garajan, verbazen, schrikken, fagarajan, verbaasd, versteld staan; van taga, volgen (?), fatagtaga, achternazetten, vervolgen; van ungo (?), faungo, wegjagen, uitdrijven; van mòta, vast ingestopt, famotmòta, met geweld instoppen tot het hard is, bijv. kapok in een kussen; van taroril, een touw spannen, fatarwil, aantrekken van een touw om het te spannen.

Voorbeelden in zinnen zijn: fare nfakiko na saopat tja, fare hnjao tja namorit fare nmat bená, en hij snoerde zich de buikband sterk om, vervolgens brak zijn buik af en hij stierf ook; jaifataiftaifo pa, ik begrijp er niets van; jaifatōtō $p a$, ik weet er niets van; wawai tja nfarera mantjawa dfatōto $i$ pa, waarheen uw kind is weggelopen, zij weten het heel niet; ite tfaroro tuba su ta Iua ta mafia, wij bekijken te voren eerst terdege, wat goed is; mamajas gagau tja nfafasapang mamajas tanpukpuk $i$, de pijp stootte de rook uit in brokken (stukken); mani tja nfagarajan ja, die vogel doet me verbaasd, versteld staan; 
jaifatagtaga maidjanga tja, ik achtervolg het hert; fare dfaungo $i$ lali lata $n a$, vervolgens zij drijven ze daarheen naar de vlakte; jaifaungo si, ikafena si pa, ik jaag hen weg, ik kan het niet; popodje taie nmòta famafia, dit kussen is heel goed volgestopt, hard; mfatawil wala tja, trek het touw aan!

Ten slotte treft men in het Bulisch nog vrij veel werkw. aan met het prefix $f a$-, die wij niet goed in een der drie bovenstaande categorieën weten onder te brengen. Soms komt het ons voor alsof men door middel van dit prefix intransitieven vormt van transitieven, maar ook lijken er woorden met $f a$ - te zijn, waarbij het element meer als praeformans is te beschouwen ${ }^{83}$ ).

Wij geven nu een aantal van deze ons onduidelijke gevallen; mogelijk zal bij nader onderzoek meer licht verschaft kunnen worden.

Fapun, doodslaan, van pun, slaan, doden; farera ${ }^{84}$ ), hard lopen, weglopen; fagon re fawāg, kopen en verkopen, van gon, kopen en $w \bar{a} g$, verkopen; fapalas, betalen, van palas, betalen; faring, van ding, naaien; farwau, sagoekloppen, van wau, mawau, oud, rijp zijn van de sagoepalm, cocospalm, enz.; fasinanga, van sinanga, braden; fasosal, spijt, berouw hebben, van sosal, spijt, berouw; afetang, van etang, tellen, vertellen; fablë $^{85}$ ) spelen, spelen met; famumumo, fluisteren, van mumum (?); fabinga, berichten, kennisgeven aan, van bing, binga (?), bericht, tijding; famumuis, de neus snuiten, van mumuis, snot, slijm; fatotfa van totfa, wassen van kleren; fameta, op jacht gaan met een geweer, van eta, meta, raken, geraakt; faplagai, wurgen (?), van aplagai, in de nek, bij de keel grijpen; fatila, iets al trekkend vasthouden, van tila, met de hand vasthouden en van zich afhouden; fatig, plaatsen, zetten, van tig, plaatsen (?); fafnek, van fnek (?), door de neus spreken; faatang, onthalen, voorzetten, van atang, maatang, zichtbaar, opgedist (?).

Voorbeelden van gebruik zijn : mati ffapun ná, gij zult niet doodslaan; mafapun, moordenaar, doodslager; ja re au itfarera mtoal be ja, ik en gij, wij lopen hard, hard ook ik, d.w.z. ik loop harder dan gij; luf tja nfarera lalī, de muis liep hard daarheen; smat lalo tadfagon tadfarwāg, velerlei mensen, die kopen en verkopen, d.w.z. handelaren; anim lingan

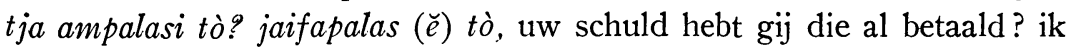
heb al betaald; jaiding falai, ik naai zeilen; tuka faring, kleermaker;

83) Vgl. S. J. Esser, Klank- en Vormleer v. h. Morisch II, par. 293, 306-308, 234,235 .

84) De stam is mij niet bekend. In 't Nuf. komt frar voor, zie F. J. F. van Hasselt, Nufoorsche Spraakkunst, p. 12 en 20.

85) Vgl. Mab. sibe; Geb. abie; Pat. sjabe. 


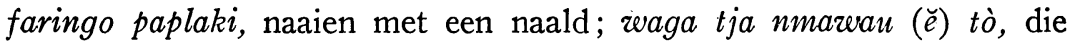

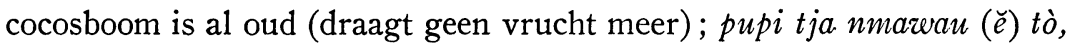
die sagoeboom is al oud (geschikt om geklopt te worden); mafawau, sagoeklopper; jaifawau taine wàngto ja pa, sosam npeia ga!, ik klop nu hier sagoe, er is geen inhoud, de invloed van een dode doet dat maar!; gabe dtjinanga paubé, indien zij het nog niet gebraden hebben (braadden); smat nfasinanga mali ulan loló, men braadt in pannen; bo mesamul mati mfasosal na, opdat gij later geen spijt hebt; fasosla, spijt hebben over, jaifasosla ifān ja ndadi pa, ik heb er spijt over, ik ga ik, het gelukt niet; smat ta nafetang, de man die vertelt, verteller; mali botfablē et mali suo tja, komt, wij zullen gaan spelen met een vlot (vlotje-spelen) in de baai; fare dòma re malinging wawai tja nfān $n f a b l \bar{e} b$, vervolgens 's morgens en 's namiddags de jongen ging maar spelen; mati mfablē smat na, wil niet met de mensen spelen; sidtjula jaifabinga habar tja mali pnu ta o farumi, zij bevalen mij dit bericht ik deel het mee aan alle deze dorpen; smat ta nfatotfa, iemand die kleren wast, een wasman; smat ta nfatotfa ntotfa obat tja tò, de wasman heeft deze sarong al gewassen; smat tanfameta, een jager (met een geweer); mfatila wala tja, houd dat touw vast!; fatig än, eten opbrengen, gereed zetten; jaipande imauting fafnek, ik ben knap ik spreek door de neus, d.w.z. ik kan door de neus spreken.

Een enkele maal treft men een prefix fai- aan, dat dezelfde betekenis heeft als $f a^{-86}$ ), bijv. van teta, gelijk, even, faiteta = fateta, aan elkaar gelijk zijn, op elkaar gelijken; gelgelto lawo nfaitetai, de verte van de tussenruimte (de onderlinge afstand) is gelijk; buk silú tasine dfaitetai, deze twee boeken zijn aan elkaar gelijk; monara tiná nngangala nfatetai $p a$, die werktuigen het bewegen, het gelijkt niet op elkaar, d.w.z. die werktuigen bewegen zich niet gelijk, op gelijke wijze; kabaja tja nfaitetai kabaja Ambon, die kabaja gelijkt op (is gelijk aan) een Ambonse kabaja; mati ite tfaiteto it re smat ta mamàgal, laten wij ons niet vergelijken met voorname mensen.

Het prefix nai- komt, zover mij bekend, slechts in een tweetal gevallen voor, nl. naifamsako ${ }^{87}$ ), naar alle zijden uitstrooien, van sake, strooien, zaaien, en naifarera, naar alle zijden hard weglopen (zoals bijv. kippen); bijv. tatalè tiná naifarera, de kippen lopen in allerlei

86i) Vgl. H. Kern, De Fidjitaal enz. p. 46 en 51.

87) Er komen ook twee uitdrukkingen voor van gelijke betekenis als naifamsako nl. fane sako en fane noru, uit elkander gaan, zich verspreiden, overal heengaan. In de Bul. woordenlijst bracht ik dit in verband met $f \bar{a} n$, gaan, doch het lijkt me onzeker, of dit juist is. 
richtingen hard weg; fare karkār nèsa farumi ta mali lata tja naifarera duwe lali isa-isa gagau na, en alle andere kikvorsen, die op het veld waren, liepen naar alle kanten hard weg, zij keerden terug een ieder naar zijn plaats.

\section{Grondwoorden van suffixen voorzien.}

De verba bestaande uit een grondwoord en een van de suffixen $-o$, $-a,-e,-i$ en $-e a$ verschillen over het algemeen niet in betekenis. $Z_{\mathrm{ij}}$ verschillen van het - meest verbale - grondwoord, dat zij bevatten, in betekenis door het feit dat zij tot direct object hebben het woord dat het instrument aanduidt, waarmee het proces door het grondwoord aangegeven, verricht wordt. Soms ook hebben zij locatieve betekenis. In enkele andere gevallen lijken zij van intransitieve verbale grondwoorden transitiva te vormen. Behalve met verbale grondwoorden (en soms met enkele grondwoorden met substantivische betekenis) worden deze suffixen ook gecombineerd met werkwoorden, die een prefix (bij voorkeur $f a-)$ bevatten.

Slechts een enkel geval is aan te wijzen, waarin één grondwoord met verschillende van deze suffixen verbonden kan worden, nl. van tig, gooien, tigeo, gooien naar, tegenover tigea, gooien met. Het lijkt daarom niet uitgesloten, dat men in deze suffixen verschillende varianten moet zien van één achtervoegsel. Regelmaat in het optreden van deze suffixen konden wij echter niet vaststellen met het materiaal, dat ons ten dienste stond. Wel lijkt het suffix -o vooral voor te komen bij grondwoorden, die op een - $a$ uitgaan, maar soms komt het ook voor na grondwoorden welke eindigen op een consonant of op een andere vocaal dan $a$, hoewel in het algemeen aan dergelijke grondwoorden vooral het suffix $-a$ gehecht wordt.

$\mathrm{Bij}$ de vorming ondergaat het grondwoord geen verandering, behalve in de volgende gevallen:

1. Indien het suffix - $o$ gecombineerd wordt met een grondwoord dat eindigt op $-a$, treedt dit suffix in plaats van deze slot $-a$.

2. Bij aanhechting van het suffix $-e$ aan grondwoorden op $-i$, treedt het suffix in plaats van deze slot $-i$. Wanneer echter deze $-i$ voorafgegaan wordt door een $l$, komt bij aanhechting van het suffix deze $-i$ vóór de $l$ te staan, bijv. gali - gaile; sale - saile.

3. Bij aanhechting vooral van het suffix $-e$ aan een grondwoord dat op consonant eindigt, wordt soms de vocaal die aan deze slotconsonant voorafgaat, geëlideerd. Andere bijzonderheden, zoals de overgang van slot $s$ in $t j$, zullen blijken uit de hieronder te geven voorbeelden. 
In het volgende zullen wij ons beperken tot het geven van een aantal voorbeelden van deze verba en van enige zinnen waarin zij voorkomen.

1. Voorbeelden van verba met het suffix -0 : van ara, beitelen, aro, beitelen met; van tafa, wannen ( $a f a$, wan), tafo, wannen met; van teta, zeven, teto, zeven met; van jawa, ,lijnvissen”, jawo vissen met een lijn; van totfa, wassen (kleren), totfo, wassen met; van flota, boor, ftoto, boren met; van palas, betalen, paltjo, betalen met; van $\bar{a} n$, eten, $\bar{a} n o$, eten met; van $t e$, scheppen, teo, scheppen met; van dom, drinken, dòma, drinken uit.

Zowel met instrumentale als met locatieve betekenis: van taping ${ }^{88}$ ), aansteken, tapngo, schieten met, schieten op.

Met locatieve betekenis : van làfa, komen, làfo, komen tot, aankomen; van topa, weggooien, topo, weggooien op, naar; van pei, maken, doen, peio, maken van; van totoláng, zitten, totongo ${ }^{89}$ ), zitten op; van sapil, laden, saplo, laden op, in, rijden op, saple, laden in, saple gina, goederen laden in; van $j \bar{a} l$, halen nemen, $j \bar{a} l o$, halen, nemen van, voor.

Voorbeelden in zinnen zijn: jaikano tjibobo, ik eet met een lepel; jaikaro arara, ik beitel met een beitel; jaitafo pupurang, ik wan met een wan; jaiteto teteta, ik zeef met een zeef; jaitapngo snapān, ik schiet met een geweer; jaitotfo sabun, ik was met zeep; jaipaltjo tabako, ik betaal met tabak; dlàfo pnu tja paubé, zij waren nog niet in het dorp aangekomen; mani isa ntotongo màgal puis ai tantub mali waja bobó na, een vogel zat op een tak boven in een boom, die stond (leefde) aan de rivieroever; fare ntopo $i$ ai akako nap, en hij wierp hem een twijgje toe naar beneden; smat isa nut snapān bontapngo $i$, iemand bracht een geweer willende op hem schieten; fare kolano tja ntjaplo kapal isa, vervolgens de koning scheepte zich in op een schip; taga jailàfo mantane, pas ben ik hier aangekomen; jaijefo reareai taie nlois, ik werp de schuld op dit kind hij stal, ik verdenk er dit kind van, dat hij stal;

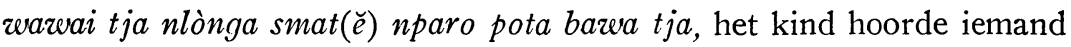
voor de deur kloppen; popei butu ni djodjaga smat malois dloiso $i$, vannacht de oppasser van de markt de dieven bestalen hem; ntjefto anamam pira na, hij nam zonder vragen onze sagoekoeken weg; dpeio si ala, zij maakten ze tot aas.

Voorbeelden van combinaties van het suffix $-o$ met grondwoorden waaraan reeds een prefix is toegevoegd: van jataf, dak, dakbedekking, fajatfo, dekken met; van ising, plaatsen, stellen, opbergen, faisngo,

88) Vgl. Nuf. Radj. IV tapin.

89) Waarom de vorm totongo is en niet totolngo is mij niet duidelijk. 
doen plaatsen op, aandacht schenken aan; van pnu, dorp, fapnuo, in een dorp wonen, bewonen; van tcam, blijven, fatemo, bij iemand achterlaten; van $j \bar{a} l$, nemen, halen, fafajālo, verzamelen, het een met het ander halen; van teta, gelijk, even, faiteto, zich vergelijken met; van mauting, spreken, famautngo, tot elkaar, met elkaar spreken; van mafia, goed, famafio, met elkander goed maken, vrede sluiten; van utan, vraag, vragen, fautno, vragen naar, manen; van sung, binnengaan, fasungo, doen binnen gaan, iemand iets voorhouden; van $\mathrm{em}$, zien, faemo, laten zien aan; van $e p$, storten, morsen, maraepo, ergens op gestort, gemorst zijn; van paril, vallen, marapaulo, van zelf vallen op, over; van si, sluiten, dichtdoen, fasisio sluiten voor; van telam, kiezen, uitzoeken, fatelmo, richten op van een geweer bijv.; van sipat, masipat, dwars, famasipato, dwars over elkaar heenliggen.

Voorbeelden in zinnen zijn: ebai tja jaifajatfo sengk, dat huis dek ik met zink; mati ffaisngo ni meu deltji riri maping si nas, wilt niet uw aandacht schenken aan (vestigen op) de vrouwen van uw makkers ${ }^{30}$ ); ijā tja nmaraepo musalā popó, de saus is op de mat gemorst.

2. Voorbeelden van verba met het suffix $-a$ : van pes, slaan, pesa, slaan met; van $\mathrm{cm}$, zien, $\mathrm{ema}$, zien met; van balat, binden, omwinden, balta, omwinden met; van folas, op een wig slaan, folta, slaan met, uitslaan; van tolas, afdrogen, toltja, afdrogen met; van sagu, steken, sagua, steken met.

Met locatieve betekenis: van sapang, uitgaan, sapnga, ergens uitgaan, naar buiten komen, uitgeleiden; van sung, binnengaan, sunga, binnengaan in, tot; van $i e l$, rondgaan, icla, rondgaan om, in; van $u f$, blazen, $u f a$, blazen op.

In enkele gevallen lijken de verba met $-a$ van intransitieve grondwoorden transitiva te maken, bijv. van lif, amlif, lachen, amlifa, lachen om, iemand uitlachen; van peke, ontlasting hebben, lozen; peka, eieren leggen van vogels; van basam, gevoelen, basma, iets ondergaan, gevoelen; van garajan, zich verbazen, garan-ja $\left.{ }^{91}\right)$, zich verbazen over; van mat, sterven, dood, màta, sterven aan; van agal, ophalen van een prauw, agla, ophalen voor. Soms lijkt het alsof -na gesuffigeerd wordt, bijv. malongna, luisteren naar, van lònga, horen; misschien ook: aslongna, verspieden, uithoren, met een voor mij onverklaarbaar as-als voorvoegsel, en ongna, bijten in, met, van ong, bijten.

90) D.i. de vertaling van: gij zult niet begeren uw naasten vrouw; het woord nafsu, begeren mag men in dit geval niet gebruiken.

91) Met een eigenaardige verspringing van de slotmedeklinker $n$ voor $j$. 
Voorbeelden in zinnen zijn: jaikema, jamtak, ik zie met mijn ogen; màta amnutup, sterven door verdrinken; màta pisi, sterven aan ziekte; màta bodiga, sterven door een tovermiddel; wōl pusa tatalē tja npeka guratji, op zekere dag legde de kip goud (gouden eieren); fare kabil wawaio tja namlifa $i$, vervolgens lachte het jong van de geit hem uit; toltja obat, met een sarong afdrogen; fare nmomsa sabur ni bukbuk mali uhngo na, vervolgens wreef hij zich in met het schuim van de zeep op het gelaat; fare $h n j \bar{e} t j a n$-garan-ja, vervolgens de moeder verbaasde zich over (wat zij hoorde); kamasefa wawaio tja nuwea $i$, het jong van de kamasefa hij bracht het (naar zijn huis); mderera ja, volg gij mij; ulok loló malongna lio na, ik houd er van naar zijn geluid te luisteren.

Ook het suffix $-a$ treedt op in combinatie met $f a$ - verba, bijv. van dòm, drinken, faròma, doen drinken aan; van $d u$, schuiven, voortduwen, farurua, heen en weer schuiven aan; van soseu, scheiden, fasosewa, van elkaar scheiden, verwijderen; van sau, fasau, trouwen, fasawa, trouwen met; van bàng, vermeerderen, fabànga, vermeerderen met; van basam, gevoelen enz., fabasbasma, met elkander gevoelen, gewaarworden; van djakam, beurs, verrot, fijn van iets, dat gestampt is, fadjakdjakma, het een met het ander tot één massa maken; van igas, uitdagen, grootdoen, faiksa, zich verhovaardigen op, laten voorstaan op; van iwan, afwisselen, faizena, met elkander afwisselen; van kas, splijtsel, snede, fakaskasa, in splijtsels verdelen; van dirak, zich verplaatsen, verhuizen, fadirirka, met elkander zich verplaatsen, verhuizen naar; van sure, deel van de vangst, dat men zijn vrienden aanbiedt, fasurea, verdelen onder velen.

Voorbeelden in zinnen zijn: wōl pusa inem kobo isa tanfadjakma rakrak bet, op zekere dag zag hij een buffel, die tuingrond dooreen werkte; nmomsa kakamo pilú na fairena mali smo pero na, hij wreef met zijn beide handen met elkaar afwisselend aan zijn lippen; itetfabasbasma it betò, wij werden het ook met ons allen gewaar; lalau tja jaifabanga waja, dat geneesmiddel vermeerderde ik met water; popolulu tiná re ni marapurus, gabetá dfarurua na, die balletjes hebben gaatjes, diensvolgens (daarom) zij schuiven ze daaraan heen en weer (kunnen ze heen en weer geschoven worden); bàhnga smat malois silú dfarera kobo isa, eens twee dieven zij liepen hard weg met een buffel.

3. Voorbeelden van verba met het suffix $-e$ : van duri, nederdalen, dure, nederdalen met, naar beneden brengen; van tapi, uithozen, tape ${ }^{92}$ ), uithozen met (bijv. met een roeiriem); van sali, roeien,

92) Het is niet onmogelijk, dat in deze laatste twee voorbeelden de $e$ ontstaan is uit de slotklinker $i$ en het suffix $-a$; missichien pleit daarvoor nog, dat ik in 
scheppen, saile, roeien, scheppen met; van tulis, schrijven, tultje, schrijven met; van gezert, klimmen, geutje, klimmen met, naar boven dragen; van darwil, klimmen, daule, klimmen met, op; van turuk, een rivier oversteken, turke, een rivier oversteken met, van tibil, lassen, verbinden, tible, lassen, verbinden met; van kawril, ophangen, kaule, ophangen aan, dragen aan.

Met locatieve betekenis: van $f \bar{a} n$, lopen, gaan, $f \bar{a} n j e$, lopen, gaan op, met (nl. mensen en dieren, die zelf lopen); van $t j u t$, stoten, stompen, tjutje, stoten met, tegen; van sisip, insteken, sispe, ergens tussen steken, bijv. een kapmes tussen de atap; van lapis, vrij, los, verlossen, lapse, verlossen van; van aliu, voorbijgaan, aliuwe, voorbijgaan aan; van sapil, laden, saple, laden in.

Ook lijken door middel van dit suffix van intransitieve verbale grondwoorden transitiva te worden gevormd, bijv. van gali, graven (met de hand, met een cocosschaal), gaile, begraven.

Voorbeelden van gebruik: mfānje smat tja, neem die man mee; nfānje ntu tasiá lalī re malī, zij liep met haar kinderen her- en derwaarts; smat na nfānje fitjori, de mens hij loopt op hun voeten ${ }^{83}$ ); jaisaile siseli, ik schep met een schepriem; jaitultje tinta, ik schrijf met inkt; amtultje mangsi subé, gij schrijft nog met een griffel; owle fofoas, ziek zijn door steenpuisten; owle làtan, ziek zijn door de wind; turke pelang, een rivier oversteken met een prauw; mlapse am mali ta majai, verlos ons van de (het) boze; fitjo wela re balit dtible ai tjitjapo bo $m t u$, de rechter- en linkerpoten zij verbinden met een eind hout, opdat ze sterk zijn; kabil tja naliuwe ni deltji o pa, die geit kon zijn makkers niet passeren; pät tulis tja jaboikaule, de lei, ik kan ze aan een vinger dragen; jaisaple pupi, ik laad sagoe in een prauw; wōl pusa wōl pusa sidtjula $i$ dure waga pio, elke dag zij bevelen hen cocosnoten naar beneden te brengen.

Ook na werkwoorden met $f a$ - kan het suffix $-e$ optreden, bijv. van lezerit, iets voor de buik dragen, faleuleutje, samen iets voor de buik dragen (bijv. een kist, die men samen wegdraagt); fagentje, fadaule, iets doen opklimmen tegen (bijv. een slingerplant tegen een boom); van taping, aansteken, in brand steken, fataptapnge, het een en ander

een verhaal ook durea vond; gabe awe mmasie ja, mdurea loan boigewit, indien gij, gij hebt medelijden met mij, laat naar beneden de ladder, opdat ik opklimme, tenzij men lezen moet: mdure $j a$, ,laat voor mij maar beneden", doch in hetzelfde verhaal leest men ook fare Nur ndurea loan, vervolgens Nur liet de ladder naar beneden, en hier is geen vergissing mogelijk.

93) Vreemd is hier het enkelv. $n$; men zou het meerv. $d$ verwachten. 
met elkaar in brand steken, verbranden; van $k i k i$, strijken, drukken, fakikie, strijken, drukken met, bijv. de hand of vinger; van tutuling, zelf, alleen, eigen, fatutulnge, voor of van zich zelf zijn; van muming, een gewelddadig gestorvene, famumnge, baren, voortbrengen; van ewris, vernielen, bederven; fazwe use, vernielen met, voor ${ }^{94}$ ); van tibil, lassen, verbinden, fatibtible, op vele plaatsen aan elkaar verbinden met; van tjul ?, aftjule, aantonen, aanwijzen.

Verder komt voor van tjut, stoten, stompen, atjutje, stoten met, tegen, het enige mij bekende geval van combinatie van het prefix $a$ met het suffix $-e$.

Voorbeelden van gebruik zijn: mfakikie kakamom fauat tu na, wil niet al te hard met uw hand strijken; welisá isa-isa npei ni karadjāng fatutulnge, laat een ieder zijn eigen werk doen; paplaki tankokopē tja naftjule ni oras, de korte naald (wijzer) wijst de uren aan; jaikatjutje fitjok mali pāt, ik stootte met mijn voet tegen een steen.

Twee verba op -e zijn mij niet geheel duidelijk, nl. dahle en otje. Van dahle (van las, nabij) is het prefix $d a(d+a)$ me niet duidelijk; men heeft ook alas dus $a+$ las, nabij zijn; dikwijls krijgt dit alas de $e$ achter zich, vooral wanneer het gevolgd wordt door tò, bijv. pelang tja

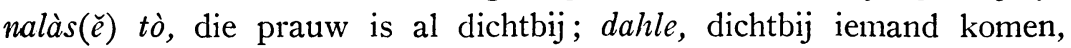
naderen, benaderen" is ontstaan uit dalàse, dalse, dasle; gabe ndahle it, botlònga, indien hij ons nadert, zullen wij horen; mati mdahle ja ná, wil mij niet naderen.

Mogelijk behoort òtjé ook hier thuis, althans de vorm doet het vermoeden. Het komt nu slechts in deze vorm voor. Een eigenaardigheid van dit woord is, dat het belanghebbend voorwerp in een bezit. vnw. als het ware wordt samengevat met een nader genoemd lijdend voorwerp, bijv. mòtjé nik kostong fapusa, geef mij een enkele halve gulden; mòtjé nak pinge wakòtjé, geef mij een beetje rijst; mogelijk geldt dit alleen voor de imperatief, want men vindt ook: kòtje, kòtje au $p a$, wij geven, wij geven je niet.

4. Voorbeelden van verba met het suffix $-i$ : van tinak, breeuwen, tinaki, breeuwen met. Met locatieve betekenis: van sulit, weken, laten doordringen met vocht, suliti, weken in; van lola, omkeren, terugkeren, lolai, terugkeren naar, tot.

In sommige gevallen heeft het grondwoord substantivische betekenis, bijv. van tjibobo, lepel, tjiboboi, lepelen; van sarara, puimsteen, sararai, met puimsteen schuren.

94) $\mathrm{Na}$ het prefix fa- komt hier een $w$ voor, die ik niet verklaren kan. 
Voorbeelden van gebruik zijn: jaitjiboboi gule-gule, ik lepel rijstepap; pelang tja jaitinaki bali, ik breeuw die prauw met nibung-zwam; waja ntjuliti $p a$, water dringt er niet in door, d.w.z. het is waterdicht; jaisasarai eta, ik schuur een kapmes met puimsteen; fare nlolai lali ai tja pu, vervolgens hij keerde terug naar de voet van de boomstam.

In een aantal gevallen heeft het suffix $-i$ een versterkende of meervoudige kracht ${ }^{95}$ ). Voorbeelden zijn: van golit, inwikkelen, golgoliti, iets geheel, terdege inwikkelen; van $m \bar{a} n g$ ?, lawaai, geroezemoes, ma$m a ̄ n g i$, veel lawaai maken; toitolai (grondwoord?), schaterlachen; $t a d b i$ (grondwoord?), striemen.

Voorbeelden van gebruik: mati fpei māngi ná, wilt geen lawaai maken; fare hmak re hnjēksi dpidtjamlif, mai jaitotolai, mijn ouders glimlachten, maar ik schaterlachte.

Ook met werkwoorden met het prefix $f a$ - kan het suffix $-i$ gecombineerd worden, bijv. van puk, klont, brok, bal, fapukpuki, als brokken, ballen maken; van $u t$, brengen, faututi, aldoor brengen, voortdurend, bijv. smat tja nририр fantuti, die man hoest onophoudelijk.

In één geval zou men kunnen denken aan een suffix -oi met versterkende of meervoudige kracht, nl. van peke, defaecatie, pekpekoi, diarrhee hebben, bijv. zeawai tja npekpekoi, dat kind heeft diarrhee.

Misschien vindt men het suffix $-i$ ook in ahai, al wat, (van $a h a$, wat), $i s e i$, al wie (van ise, wie), en in de richtingsaanduider $-i$ ( $f a \bar{a} n$ bet $i$, naar de tuin gaan; mali it lali butu $i$, komt, laten we naar de markt gaan.

5. Voorbeelden van het suffix -ea: van tig, gooien, tigea, gooien met; van lit, kleven, litea, kleven met; van kati, snijden, katea, snijden met; van opi, inwikkelen, opea, inpakken met; van tota, hakken, totea, hakken met; van tabi, een fuik uitzetten, laten zinken, tabea, een fuik laten zinken met (bijv. stenen); van opa, vliegen, opea, vliegen met.

Voorbeelden van gebruik: litea soip, plakken met sagoepap; naast litea komt ook lita voor, bijv. msula nlita tiba taie tatmu, beveel hij soldeert deze schepper met lood; ifea dab, met een mat als onderlaag cioen zijn; jaitotea eta, ik hak met een kapmes; jaikatea eta nenèna, ik snijd met een mes; jaitigea fun tja pāt, ik gooi die hond met een steen; taga nopea pitpitan ta bersi, pas verbond hij het met een schone zwachtel.

Het suffix -ea wordt niet gecombineerd met verba welke bestaan uit een grondwoord en een prefix.

95) Vg1. S. J. Esser, Klank- en Vormleer van het Morisch II, p. 357. 


\section{Enige wat samenstelling betreft niet duidelijke verba.}

Enige wat hun samenstelling betreft nog niet geheel duidelijke werkwoorden zijn: van lif, amlif, lachen, pidtjamlif, glimlachen (Maba pitjemlif; Waigeo mamlif; Gebe amlif kalisa); inpidtjamlif nem $n t u$ ta, zij glimlachte (toen) zij haar kind zag; van teka, uitslaan van kleren, opschrikken, ladteka, ( $l a=l a i$, alsof, aldus; $d$ pers. vnw. 3e pers. m.v.), alsof zij laten opschrikken, laten schrikken; ladteka ja nanai, zij lieten mij zoëven schrikken; fare ladteka $i$, sababe inonau djegeri tja bonān $i$, vervolgens hij schrikte op, omdat hij dacht (meende) de djegeri hem zou (wilde) opeten. Gelijke betekenis heeft ladtjub (van $s u b$, optillen, opspringen, $l a+d+s u b)$; van $d i b$, kaatsen terugkaatsen, laddibdib $=l a+d+d i b$-dib, alsof zij aldoor terug kaatsen; laddibdib pa baki, alsof zij aldoor niet terugkaatsten, alsof zij aldoor heen en weer zweefden; ladpesa (van pesa?) $=l a+d+$ pes $+a$ (?), alsof zij slaan met, op, ladpesa si, alsof zij slaags waren met.

De vervoeging van deze woorden met $l a$ is :

ladteka ja, ik schrik op

ladteka au, gij enz.

ladteka $i$, hij ladteka am, wij (excl.)

ladteka it, wij (incl.)

ladteka mu, gijl.

ladteka si, zijl.

\section{Wijzen van het werkwoord.}

Het Bulisch heeft slechts voor de imperatief een afzonderlijke vorm. De imperatief enkelvoud wordt gevormd door voor het werkwoord het korte pers. vnw. van de $2 \mathrm{e}$ pers. enkelv. $m$ te plaatsen, en het meervoud door er op dezelfde wijze met het korte pers. vnw. van de $2 \mathrm{e}$ pers. meerv. $f$ voor te zetten, bijv. mfisan, kies, zoek uit!; fseli, eet!; ffān, gaat! mwagfo fun isa, vang een hond; mbalat $i$ famtu, bind hem stevig vast; msai nim uta na, kam uw haren (hoofdhaar); mfalawil wala tja, trek het touw aan; mfadidlao jataf tiná, leg die atap wat verder van elkaar af. Soms versterkt men het gebod door achter de zin de nadrukswijzer $o$ te zetten, bijv. neka $e$ ! meantji famafia o!, meisje, verzorg ze goed hoor!

Het bevel wordt soms verzacht door voorvoeging van het woord tofnga, iets beproeven (van tofang, proberen, beproeven), of van het Mal. tjoba, bijv. fare tanati tja nua tawawai tja: tofnga mosal puis failān tja pu, en de oudste zeide tot de jongste: probeer (ga) eens staan op het voetstuk van de mast. Ook wel brengt men verzachting 
aan door achter de zin het woordje $g a$ te plaatsen, bijv. $m f \bar{a} n(\breve{e})$ bometang si ga, ga jij eens om hen te tellen.

De uitdrukking van een verbod, een wens, een voorstel e.d. geschiedt in het Bulisch door met afzonderlijke woorden het werkwoord nader te bepalen.

Een verbod wordt uitgedrukt door het woord mati, wil niet, laat niet, gevolgd door de korte vorm van het pers. vnw. van de 2e pers. enkelen meervoud, $3 e$ pers. enkel- en meerv. of $1 \mathrm{e}$ pers. meerv. (excl. en incl.) en de nadrukswijzer ná achter het werkw. of aan het eind van de zin.

Voorbeelden zijn: mati mlois ná, steel niet, wil niet stelen; mati fdadararea ni meu deltji ná, wilt niet uw makkers beliegen; aje ke! mati mtangis ná tò, moeder! schrei niet meer (langer)!; mati famtuli ná, wilt niet slapen; mati mfakokitji smat( $\breve{e})$ nèsa ná, wil niet andere mensen minachten; mati mfamajai ná su, wil het niet eerst slecht maken, minachten; mati ffasigsigo ná, wilt elkaar niet blameren; mati itetfaiteto it re smat ta mamàgal ná, laten wij ons niet vergelijken met voorname mensen.

Een enigszins afwijkende betekenis heeft mati in zinnen als : mati be ja mantaine, het is maar goed, dat ik hier ben; mati be jaigali au, het is maar goed, dat ik je help; mati be na tjero silú, het is maar goed, dat zij twee ketels heeft.

Men treft ook verbiedende zinnen aan als: fare tawawai tja nu laitane: mati ná o!, en de jongste zeide aldus: wil toch niet!

Een wens wordt uitgedrukt door vóór de zin te plaatsen de woordjes dor be, vragen, verzoeken slechts, of renta, reden, moge het gebeuren, bijv. dor be ulan tja ndadi, moge het gaan regenen; dor be nlàfo, moge hij komen; dor be $i$ malī, moge hij hierheen komen; renta $i$ mali be tò, moge hij maar herwaarts gekomen zijn; renta ndadi be tò, moge het maar gebeuren; renta smat nfamamàgal angahnjom, moge men uw naam grootmaken, eren; anim man renta ndadi, moge $\mathrm{Uw}$ wil geschieden!

Een voorstel wordt uitgedrukt door vóór de zin te plaatsen de woordjes mantapa, het is goed, laat ons, of welisá, het is goed, laat ons, tofnga, proberen, beproeven, een enkele maal ook door de nadrukswijzer $o$ achter de zin te plaatsen, bijv. mantjapa jaidelo lalinge nèsa, laat mij een andere weg volgen; welisá igon padoman, laat mij een bril kopen; welisá itetdadikan smat na, laat ons mensen maken; tofnga be jaitofang fapusa, laat mij er één van proberen, proeven; jaisaplo $i$ wakòtjé o! laat mij er even inzitten!

Verh. dl. X. 
Ook bezigt men nog mali, hierheen, herwaarts, kom; mali itlali butu $i$, komt laat ons naar de markt gaan.

De voorwaardelijke wijs wordt uitgedrukt door het woord bereā, ,als 't maar, moge het maar" achter het werkwoord of de zin te plaatsen; noodzakelijk is dit evenwel niet, daar ook uit het zinsverband soms wel kan opgemaakt worden, wat men bedoelt.

Voorbeelden: infān bereā, als hij gegaan ware; gabe infān bereāa, indien hij gegaan ware; gabe ifān bereā ijal $i$, indien ik gegaan ware, ik haalde het; gabe laina berea a, amlois, indien dat aldus is, gij steelt; maske itetpei parakara pusa ta mamàgal bereā, bang tjutjuping na itetmarapaulo parakara ta nenèna, al verrichten wij nog zulk een grote zaak, komen wij toch soms te vallen over een kleine zaak; gabe ja, isa pa tanfakokitji ja laisawa kobo ta nbodo taie, indien ik, niets zou mij vernederen zoals deze domme buffel; fare woi tja nu: ja naga isuna $i$ ja gare ja re $i$ kmauting wakòtjé au, en de haai zeide: ik als ik haar maar bereikte (aantrof), dan ik en zij, wij praatten eerst een weinig; nanai woi tja nu, gabe ntjuna au, gare i re au maumauting wakòtjé su, zoeven de haai zeide, indien hij $u$ bereikt (angetroffen) had, dan hij en gij hadden eerst wat gepraat.

„Al zou ook .... toch" wordt weergegeven met renta .... mai, bijv. renta laina .... mai nane tizer, ,laat het zo zijn .... maar geld moet er wezen.

Een noodzakelijkheid wordt aangeduid door de woordjes: renta, zeker, stellig, moeten, dat dan vóór het werkwoord komt te staan; nane, stellig, zeker, moeten, behoorlijk; gabe renta, het moet, het behoort. Bijv. nane jaifasawa au, het is zeker ik trouw met je, ik moet met je trouwen; wawai tja renta nmat, dat kind zal zeker sterven; nafale smat lifo renta duze, alle vreemdelingen moeten terugkeren; tariri lingan renta dtjagam, hun schulden moeten geïnd (ontvangen) worden, of : moeten zij erkennen; jainane iduk punpun, ik behoor, ik ontvang slaag, ik behoor slaag te krijgen; mantri laling tja nane dtail $i$, die wegopzichter behoren ze te prijzen; bàhnga-bàhnga gabe renta wawai sakola dut mangsi, elke dag behoren de schoolkinderen griffels mee te brengen; gabe ise nising tizer renta nmòsi, al wie geld neerlegt, zeker hij verzadigt zich; nane meuftopo sadaka $\bar{a}$, gijl. behoort (moet) offers brengen (wegwerpen).

De ontkenning wordt uitgedrukt door de woordjes pa „niet”, paubé „,nog niet”, pantò „,niet meer” achter het werkwoord of de zin te plaatsen, soms nog versterkt door de nadrukswijzer $o$ en door het op zich zelf staande pene, neen, niet, geen, vgl. Mal. bukan. 
Voorbeelden zijn: maping tja nailou pa, die vrouw wil niet, stemt niet toe; jaikem smat pa, ik zie niemand; jaikem au pa, ik zie je niet; jaidela au pa, ik geloof je niet; wahle amtō mwatja pa laha, misschien kunt ge niet lezen; gabetá meta mani tja pa, diensvolgens raakte hij die vogel niet; jaiderértji pa, ik volg hen niet; dlàfo pnu tja paubé, zij bereikten dat dorp nog niet; jaisung sakola paubé, ik ga nog niet school; waja tja ndak paubé, het water kookt nog niet; waja tja ndak pantò, het water kookt niet meer; ntamaga nafena pantò, hij kan geen sirihpinang meer kauwen; fare ni balit tja namjangis, nem pantò, en zijn tegenstander was verdwenen, hij zag hem niet meer; pene, laina $p a$, neen, zo is het niet; ingahnjo ise? Marina? pene, hoe heet zij? Marina? neen.

Een vorm, die overeenkomt met onze infinitief, kent het Bulisch evenmin. In vele gevallen gebruikt men vervoegde vormen, bijv. $d n j a n j i$ $d d u k p a$, zij kunnen niet zingen, zij zingen, zij kunnen niet; itettjung tamtuli, wij gaan binnen wij slapen, wij gaan binnen om te slapen; ameksapange kningo, wij gingen naar buiten wij kijken (om te kijken); taga ameksunge kamtuli arabana tja lio, pas waren wij binnengegaan wij slapen (om te slapen), de tamboerijn z'n geluid (werd geslagen); ifaungo si ikafena si pa, ik jaag ze weg ik kan ze niet, ik kan ze niet wegjagen; mesamúl taine dbiasa dpake lampur, tegenwoordig zijn ze gewoon ze gebruiken lampen (zijn ze gewoon lampen te gebruiken); amektultje tinta kduk paubé, wij schrijven met inkt wij kunnen het nog niet, wij kunnen nog niet met inkt schrijven; jaibarani isaplo djara tai $p a$, ik heb geen moed ik berijd dit paard, ik durf dit paard niet te berijden.

Men ontmoet ook wel $m a$-vormen, die in het Ned. met infinitieven kunnen worden weergegeven, bijv. ulok loló malongna lio na, ik houd er van naar zijn geluid (stem) te luisteren; fare saninipa a tja nmasalawe mali matmàta amnutup tja, vervolgens de wesp hij ontkwam aan de dood door te verdrinken.

Verder treffen wij ook onvervoegde werkwoorden aan, die in het Ned. met een infinitief kunnen worden vertaald, bijv. nga tja emo mnu $p a$, de maan is niet lang te zien (zichtbaar); hjēk re hmaksi dtjula ja sung sakola, mijn ouders ze bevelen mij school te gaan; fakotalē na nfonla paubé, het twisten houdt nog niet op, de twist houdt nog niet op.

„Er is, bestaat” wordt in het Bulisch aangeduid door het woordje $e n$ vóór het onbepaalde vnw. $i$ of enig plaatsaanduidend woord, bijv. eni, het is, er is; enlali, er is daar, er is; enmali, er is hier, aan deze zijde; enmana, er is daar; entane, er is hier; ende, er is en = en; eni pa, hij, 
het is er niet; eni pantò, het is er niet meer; en paubé, er is nog niet; enpantò, er is niet meer.

Voorbeelden in zinnen: smat ta nojoi fun tja, eni pa, de jager hij was er niet; nim besi tja lufe ntetal i, ga eni pa, uw ijzer de muizen aten het, diensvolgens is het er niet; matjang tja eni pantò, de tijger hij was er niet meer; blewing na enmana, er zijn loophoenders; pupi enmana? enmaná, is er sagumeel? er is; enmana ndumi, het is er alies, alles is er; aizeani lālo ta enlali $i$ na, alle dieren, die daar waren; waja na enpantò, er is geen water meer; egat rakrak na enmana? enmana pusa $b e$, is er petroleum? er is slechts één (blik); nam ulan pa? entane, hebt gij een pan? er is hier.

Zgn. onpersoonlijke werkw., die in het Nederlands met het onbepaalde vnw. „het” gebruikt worden (bijv. het regent e.d.), geeft de Buliër weer door een eenvoudige vermelding van het substantief. Sema tò, het is al licht, het is reeds morgen; dòram tò, het is al nacht, donker; latan $p a$, er is geen wind, het waait niet; ulan $p a$, het regent niet; lemlem, het bliksemt; $d u b$, het dondert.

Soms bezigt men het onbepaalde vnw. $i$ achter het woord, bijv. nesai, het is anders; ulani, latani pa, het regent, het waait niet, het is regen, geen wind; mfànàsi, het is warm, het brandt, bijt; wōl mafiai, het is een mooie, goede dag; woll rame Walandai, het is 'n Hollandse feestdag; nganga tiná, manii, de uilen, het zijn vogels; ulan taie, ulan rakraki, deze pot, het is een aarden pot; okotjesi ta ntjusai fare ta nmurai, alles wat moeilijk en wat gemakkelijk is.

\section{Tijden van het werkwoord.}

Ook voor de tijdsaanduiding worden afzonderlijke woorden gebezigd. Alleen de wijze, waarop dit geschiedt voor de toekomende tijd, doet enigszins aan een werkwoordsvorm denken. Het daarbij gebruikte woordje $b o$ wordt $\mathrm{nl}$. als het ware in de vervoeging opgenomen, bijv. jaboifān $=j a-b o-i-f a \bar{n}$, ik zal, moet, wil - ik - gaan.

1. Om aan te geven, dat men aan een handeling moet, zal, wil beginnen (toekomende tijd) gebruikt men het woordje bo, ergens vóór zijn, dat ook op zichzelf als werkwoord voorkomt, bijv. jaibo medja, ik zit voor (aan) tafel; mali anamam medja tja karapesa isa nbo $i$, vóór onze tafels staat één stoel; taun tatboboi tai jaboifān, dit jaar, dat vóór ons is, zal (wil) ik gaan. Het komt ook voor als voegwoord, bijv. welisá injanji wakotjé, bo foen tja nlònga liok na, laat ik een beetje zingen, opdat de hond mijn stem hoort; mafia be mpei jajā, bo mati nik sapi na 
dewis anam bet tiná ná, het is maar goed gij maakt een heg, opdat mijn koeien uw tuin niet vernielen.

Het woordje bo wordt onscheidbaar verenigd met het pers. vnw., bijv. jaboiseli, ik zal eten; amebokfān, wij (excl.) zullen gaan; wōl senen bonlàfo mantane, Maandag zal hij hier komen; tatalē taie bodkàti $i$, deze kip zij zullen ze slachten; làse bontjuna $i$ tò, bijna zou hij hem bereikt hebben; boilalau au ga, ik zal je maar geneesmiddelen geven.

2. Het bezig zijn met een handeling behoeft niet nader besproken te worden, daar dikwijls alleen uit het zinsverband moet worden opgemaakt of een werkwoord zonder enige nadere bepaling in de „tegenwoordige tijd" of wel in de ,verleden tijd" staat. Wordt in de zin het woordje subé (nog) gebezigd, dan is of was de handeling nog niet afgelopen, voltooid, bijv. jaikorerl subé, ik heb (had) nog koorts; intjeli subé, hij eet (at) nog; Musa namtuli subé, Musa slaapt (sliep) nog.

3. Is de handeling afgelopen, heeft ze haar beslag gekregen, dan bezigt men het woordje tò, al, klaar, reeds enz. Men plaatst het steeds achter het werkwoord of achter de zin, en gaarne gebruikt men, naar reeds eerder opgemerkt is, na een slotmedeklinker van het werkwoord een lichte pěpĕt, om daardoor de overgang tot tò te verkrijgen.

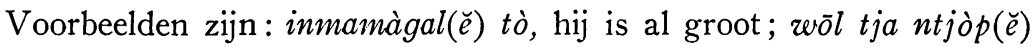

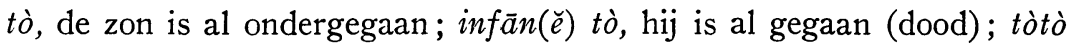
$t \grave{o}$, het is gedaan, afgelopen.

Men gebruikt ook wel de woorden tòtò, geheel af, klaar of fonla, ophouden, eindigen, bijv. ni monara na tòtò tò, zijn werk is al klaar, gedaan; jaisisòp( $\breve{e})$ nfonla, taga jaiseli, als ik gereed ben met baden, dan pas eet ik; fare dtjeli fonla tò, toen zij al gegeten hadden, en zij hadden al gegeten; buk taie nfonla tò, dit boek is al klaar (uitgelezen); $d f o$ dfonla tò, zij zijn al uitgeperst (uitgemolken).

\section{Vervoeging van het werkwoord $\left.{ }^{96}\right)$.}

Intransitieve werkwoorden.

Paradigmata van de grondw. owril, koorts hebben; totoláng, zitten; bubuláng, wit; seli, eten.

$\begin{array}{lllll}\text { Sing. } 1 & \text { ikowil } & \text { itotoláng } & \text { ibubuláng } & \text { iseli } \\ 2 & \text { mozerl } & \text { mtotoláng } & \text { mbubuláng } & \text { mseli } \\ 3 & \text { nowil } & \text { ntotoláng } & \text { nbubuláng } & \text { ntjeli }\end{array}$

96) Zie N. Adriani, De Barese sprekende Toradja's dl. III, p. 321, 322. 


$\begin{array}{cllll}\text { Plur. } 1 \text { (excl.) } & \text { kowil } & \text { ktotoláng } & \text { kbubuláng } & \text { kseli } \\ 1 \text { (incl.) } & \text { towril } & \text { ttotoláng } & \text { tbubuláng } & \text { ttjeli } \\ 2 & \text { fowil } & \text { ftotoláng } & \text { fbubuláng } & \text { fseli } \\ 3 & \text { dowil } & \text { dtotoláng } & \text { dbubuláng } & \text { dtjeli }\end{array}$

Men zou deze vervoeging de $\mathrm{k}$ or te kunnen noemen; daar naast staat de langere vorm, die meer nadruk legt op het pronomen.

Voorbeelden zijn: (van dezelfde grondw.)

$\begin{array}{cllll}\text { Sing. } 1 & \text { jaikowil } & \text { jaitotoláng } & \text { jaibubuláng jaiseli } \\ 2 & \text { amowil } & \text { amtotoláng } & \text { ambubuláng amseli } \\ 3 & \text { inowil } & \text { intotoláng } & \text { inbubuláng intjeli } \\ \text { Plur. } 1 \text { (excl.) } & \text { amekowrl } & \text { amektotoláng } & \text { amekbubuláng amekseli } \\ 1 \text { (incl.) } & \text { itetowil } & \text { itettotoláng itetbubuláng itettjeli } \\ 2 & \text { meufowil } & \text { meuftotoláng } & \text { meufbubuláng meufseli } \\ 3 & \text { sidowil } & \text { sidtotoláng } & \text { sidbubuláng, sidtjeli } \\ & & & \text { of : siledbubuláng }\end{array}$

Wederkerende verv. Verv. met de fut.aanw. $b o$.

grondw. gogan, (zich) verbergen. grondw. sali, roeien.

Sing. 1

2

3

Plur. 1 (excl.) kgogan am

1 (incl.) tgogan it

2 fgogan meu

$3 \quad$ dgogan tji

Langere vorm: jaigogan ja, enz.
boisali
bomsali
bontjali
boksali
bottjali
bofsali
bodtjali
jaboisali, enz.

Transitieve werkwoorden.

Paradigmata van de grondw. $u t$, brengen;

$d u k$, krijgen.

Sing. 1

2

3

Plur. 1 (excl.) kut

1 (incl.) tut

2

3

Langere vorm: jaikut, enz. $i d u k$

$m d u k$

$n d u k$

$k d u k$

$t d u k$

$f d u k$

$d d u k$

jaiduk, enz.
Verv. met de fut.aanw. bo. Grondw. ān, eten (transitief).

boikān

bomān

bonān

bokān

botān

bofān

bodān

jaboikdn, enz. 
Voorbeelden in zinnen: salo tane dwage tò, deze damar verkopen ze of: deze damar wordt verkocht; salo tane duti, deze damar brengen ze of: deze damar wordt gebracht; pira tane dāne tò, deze sagoe hebben ze al gegeten, is al gegeten; wo tja ddòme tò, die palmwijn hebben ze al gedronken, is al gedronken; oloan tja ni fun tja dpuni, de hond van het hoofd ze sloegen hem of: de hond van het hoofd werd geslagen; inpun ja, denabe ibos, hij sloeg mij, totdat het zwol (ik zwol); gabe jaimamàgalĕ tò fare igon sapi fadirantja boikean, indien ik al groot ben, koop ik enige koeien, die ik zal, wil verzorgen.

De transitieve werkw. komen alleen in de bedrijvende vorm voor; de lijdende vorm kent het Bulisch niet. Er komen evenwel zinnen voor, waaruit men zou kunnen afleiden, dat de lijdende vorm zich aan het ontwikkelen is uit de korte vorm van het pers. vnw. 3 e pers. meerv. $d$, bijv. waga tja dwage tò, die cocos ze verkochten ze al, d.w.z. die cocosbomen werden al verkocht.

Een eigenaardige wijze om grote nadruk te leggen op het subject is, dat men na de gewone volledige vervoeging, die reeds de nadruk op het subject legt, het zelfstandige pers. vnw. achter de vervoegde vorm van het werkwoord plaatst, bijv. jaikurwe ja, ik, ik keer terug ik (alle anderen keren niet terug); amuwe au, gij, gij keert terug gij; jaikosal ja, ik, ik sta op ik (alle anderen blijven zitten); jaifān $j a$, ik, ik ga ik; jaitotoláng ja, ik, ik zit ik; renta ja mān ja, ifān ja, omdat ik man ik, ik ga ik; welisá jaikuwe ja lalei gagauk, het is goed ik, ik keer terug ik landwaarts naar mijn plaats; ja dpun ja, ik (mij) zij slaan mij.

Indien het object in de zin voorop wordt geplaatst en dus de nadruk ontvangt, wordt dit na het werkwoord in de vorm van een pers. vnw. herhaald, bijv. nik ebai tja ikopas $i$ tò, dat mijn huis ik heb het reeds ingelost; djue e! ai taie mati mselap $i$ ná, O heer! deze boom wil hem niet vellen; Isak ni djara tja jaigon $i$ tò, dat Izaak z'n paard ik, ik kocht het al; Kore ntutá taga fun pongpongel nong $i$, Kore $z$ 'n zoon pas een dolle hond beet hem; gina taie dpa djafena $i$ pa, deze goederen zij pikoelen zij kunnen het niet. 
HOOFDSTUK VI.

$\mathrm{H}$ e t bij w o or d.

\section{Vorm.}

Naar de vorm kunnen de bijwoorden onderscheiden worden in drie groepen, $\mathrm{nl} .1^{\circ}$ grondwoorden, $2^{\circ}$ verdubbelde of gegemineerde grondwoorden, soms gecombineerd met een suffix en grondwoorden voorzien van bepaalde voor- en achtervoegsels, $3^{\circ}$ combinaties van grondwoorden.

Tot de eerste groep behoren : $s u$, eerst ; $t u$, zeer; leo, zeer; bat, zeer (van kleuren); $p a$, niet; pene, niet, neen; tò, al, reeds; nap, naar beneden; nais, naar boven; uat, sterk; be, slechts, ook; las, nabij; lau, ver; filifän, langzaam ; meas, traag, langzaam ; taga, pas ; po, pas, nieuw.

Bijwoorden als : nanai, zoëven; tjitjoal, sterk; $m t \bar{u}$, amt $\bar{u}$, sterk, vast ; nenèna, klein, weinig; kòrikòri, klein; gagalúm, week, zacht, e.d. zou men als secundaire grondwoorden kunnen beschouwen.

Tot de tweede groep behoren in de eerste plaats de bijwoorden, welke soms gevormd worden door geminatie of reduplicatie van substantieven en adjectieven (en soms van andere woordsoorten) met of zonder achtervoeging van $o$, bijv. wōlwōlo, overdag, bij dag, van wōl, dag, zon ; dòròram, bij nacht, 's nachts, van dòram, donker, nacht; laina-laina, hoe langer hoe meer, van laina, aldus; tutuo, zekerlijk, juist, van $t u$, zeer; popó, op, boven, van po, te, op; matmat, dodelijk, van mat, dood.

In de tweede plaats worden bijwoorden gevormd met het prefix $\left.f a-{ }^{87}\right)$. Voorbeelden zijn: fasefat, rechtdoor, van sefat, voorbijgaan, doorgaan; fatoal, vlug, krachtig, spoedig, haastig, van toal, vlug, sterk; faolang, rechtop, van olang, recht, waar; osal faolang, rechtop staan; fafilifān, langzaam aan, van filifān, langzaam; fawe, fauwe, weer, van uwe, terugkeren; fawàngat, sterk, intens, van wàngat, vlees, inhoud; farèrèr, gezamenlijk, gelijktijdig, van derèr, volgen; famat, dodelijk, van mat, dood.

Onder deze bijwoorden komen er voor, die in dezelfde vorm ook als causatieve werkw. dienst doen, bijv. famafia, goed maken, vrede maken, van fia, mafia, goed, mooi, doch daarnaast in verschillende andere

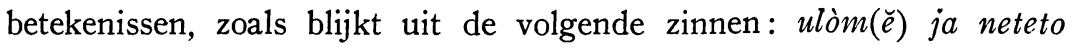
famafia mati mfabinga faisa na, uw gedurig herineren heel goed (herinner je heel goed, geef acht), dat ge van niets kennis geeft (dat ge er in 't geheel geen kennis van geeft); mlolam famafia denabé ikuwe,

97) Vgl. H. Kern, De Fidjitaal, enz. p. 46 e.v., en F. J. F. van Hasselt, Nufoorsche Spraakkunst, p. 13. 
denk er heel goed aan, totdat ik terugkeer (teruggekeerd ben); makon ditja moloko taie famufuf, wrijf deze peper geheel fijn; mpitan reala tja famtu, bind dat touw stevig vast ${ }^{88}$ ). Men zou in deze gevallen wellicht van een modale imperatief kunnen spreken.

Verder komt famafia voor in zinnen als: fare nean $i$ famafia, vervolgens hij verzorgde hem goed; mdjakam ja famafia tò, als het heel goed tot brei gemaakt is; dpande famafia, zij zijn heel knap; gabe ampareksa i famafia paubé, indien gij het nog niet heel goed onderzocht hebt; wōl takapó famafia, de allereerste dag. Soms vervult mafia de functie van famafia, bijv. nfän ja mafia, hij loopt heel goed; inopa ja mafia, hij vliegt heel goed; eta tamdalim mafia, een kapmes, dat heel (goed) scherp is; djuru tulis tja nlèfo na mafia tu, die schrijver schrijft zeer mooi (heel goed). Misschien heeft famafia een meer intensieve betekenis dan mafia.

Soms worden bijwoorden gevormd met het prefix $f a$ - en een suffix, bijv. fairena, afwisselend, van iwan, afwisselen, verwisselen; fatutuo, fatutua, zekerlijk, stellig, dringend, van $t u$, zeer; faututi, onophoudelijk, van $u t$, brengen.

Men treft ook aan wakòtjé, eventjes, een beetje, naast fakòtjé in dezelfde betekenis. Misschien heeft zich dit wa- uit $f a$ - ontwikkeld.

Bijwoorden gevormd met het prefix ma-, am-, m-, zoals amtoal, sterk, snel, vlug, krachtig, van toal, sterk, vlug; amelela, vlug, haastig, van elela (?); mafia, mooi, goed, van fia, mooi, goed, zijn als adjectieven te beschouwen, die als bijwoord kunnen fungeren.

Ons ,,met ...." en ,zonder ...." wordt weergegeven als volgt: re mtjaito, met vrees, van tjait, vrees; re maimaio, met schaamte, van mai, zich schamen; re mtangso, met, onder tranen, van tangis, wenen; re mtjaito $p a$, zonder vrees, onbevreesd; re maimaio $p a$, zonder schaamte, schaamteloos.

Voorts treft men in het Bulisch twee voorvoegsels aan voor het vormen van bijwoorden van tijd, nl. po-, dat in combinatie met het suffix $-i$ of $-a i$ optreedt en $p o p$-, dat in verbinding met het suffix -ai voorkomt, bijv. popei, gisterenavond, de afgelopen nacht; popisei, wanneer (verleden, vgl. opfis); pojangai, gisteren ; popluai, eergisteren, van $l u$, twee; poptjolai, eereergisteren, van $t o l$, drie.

In sommige bijwoorden treft men aan een prefix man-, dat mij nog niet duidelijk is, bijv. mantaine, hier, een verbinding van man + taine, deze, hier, nu of mantane (= man- + tane, korte vorm van taine),

98) Vg1. N. Adriani, Spraakkunst der Barese-taal, § 121, p. 215. 
mantjawa (= man + tjawa, sawa). Ik vermoed, dat wij hier na de $n$ van man de overgang van $n s$ in $n t j$ ontmoeten; mantj $\bar{a}$ is de korte vorm van mantjawa, waar, waarheen; mantjapa (= man + tjapa, sapa?), het is goed, laat ...., lijkt mij op dezelfde wijze te zijn gevormd.

In mesamúl, laatste, achterste, ten laatste, ten slotte, tegenwoordig, $\mathrm{nu}(=$ mesa + mul, binnen, achter), mesamúl taine, in de tegenwoordige tijd, nu, heden, vindt men het element mesa-, waarvoor ik geen verklaring heb kunnen vinden.

Sommige bijwoorden van plaats komen voor in verbinding met het woordje en, zoals enmana, entane.

Tot de derde groep, die der samengestelde grondwoorden, behoren: pantò, niet meer, uit $p a$, niet en $t \grave{o}$, al, reeds ${ }^{\text {99}}$ ); paubé, nog niet, uit $p a$, niet, en $u b e ́$, dat misschien gelijk is aan subé, nog, (su, eerst $+b e$, ook, slechts); uat tu, sterk, zeer, krachtig; bená, ook, slechts, maar, (= be + het pron. demonstr. na, dat); betò, ook al, slechts al, (=be + tò); laina, aldus, alzo, (=lai, of, aldus, $+n a$, dat); laisawa, hoedanig, hoe, alsof, (=lai + sarwa ?); laitane, aldus, zo, (=lai + tane, dit, nu, hier); mali, hierheen, herwaarts, (=ma, dat de richting naar de spreker aangeeft $+l \bar{\imath}$, plaats); lali, daarheen, derwaarts, $(=l a$, dat de richting van de spreker af aangeeft $+(\bar{\imath})$; poli, puli , daar, $=p o$, $p u$, dat aangeeft, dat iets ten opzichte v.d. spreker op de plaats rust, $+(\bar{\imath})$. Men heeft zo ook pomúl, daar binnen, $=$ po- + mul, binnen, achter; lamúl, naar binnen, mamuil, naar binnen, enz. Men zou deze bijwoorden ook wel tot de vorige groep kunnen rekenen.

Verder: malinging leo, achtermiddag, vooravond, uit malinging, namiddag, en leo, zeer; sema lele, vroege ochtend, uit sema, ochtend, en lele, vroeg; dòma sema, morgenochtend, uit dòma, morgen, en sema; wōl lāll, middag, uit wōl, zon, dag, en lāl, veel; dòròram gulumát, pikdonker, uit doròram, donker, nacht, en gulumát; pòta mdòma, vóór de norgen, dageraad, uit pòta, voor, en mdòma, morgen zijn; wōl putjuping, dagelijks, uit wōl en putjuping, ieder, elk; opfapaluan, middernacht, uit $o p$ (Geb. nacht) en fapaluan, midden; oplu, overmorgen, uit $o p$ en $l u$, twee; optjol, overmorgen, uit $o p$ en $t o l$, drie; opfat, over vier nachten; opfis, wanneer (toekomend), uit op en fis, hoeveel.

\section{Betekenis.}

Naar de betekenis kunnen de bijwoorden verdeeld worden in: 1e bijwoorden van plaats; $2 \mathrm{e}$ bijwoorden van tijd; 3 e bijwoorden van

99) De $n$ in dit woord kan ik niet verklaren. 
causaliteit; $4 \mathrm{e}$ bijwoorden van hoedanigheid en hoeveelheid en $5 \mathrm{e}$ bijwoorden van modaliteit.

\section{A. Bijwoorden van plaats.}

De bijwoorden van plaats vormen evenals bijv. in het Galelasch ${ }^{100}$ ) een rijk systeem, of schoon dat van het Galelasch nog rijker is. Men onderscheidt nl. niet alleen: hier, daar en ginds, maar geeft ook bij het ,daar" te kennen, of het aan de land- of zeezijde, op een hoger of op een lager gelegen plaats te zoeken is. Bovendien duidt men aan, of er sprake is van een $z$ ij $n$ op die plaats, dan wel van een be we ging uit of naar die plaats en in welke richting deze ten opzichte van de spreker verloopt.

Bijwoorden van plaats zijn: mantaine, mantane, ook wel alleen taine, tane, hier; manā, daar; tina, daar; natā, ginds; puis, boven; popó, boven; $p \bar{a} p$, beneden; loló, binnen, in; nap, naar beneden; nais, naar boven; wela, rechts; balit, links; wela ro balit, rechts en links. Vragend zijn: lua , waarheen?; mantjarwa, korte vorm mantja, waarheen?

Als richtingaanduiders fungeren de grondwoorden $l \bar{\imath}$, daar, plaats, dat ook dikwijls in plaatsnamen voorkomt, bijv.: Wajamlī, Jazeanlī, Bebslī, Waiflī; lau, zeewaarts; lei, landwaarts; mul, binnen, achter; talíl, buiten, voor, en de voorvoegsels ma-, dat de richting naar de spreker toe aanwijst, $l a$-, dat die van de spreker af aanduidt, en $p o$, dat ten opzichte van de spreker op de plaats rust betekent.

Het Bulisch kent ook nog een richtingaanduider, die mogelijk tot de voorzetsels moet gerekend worden, nl. $i$, dat achter het substantief wordt geplaatst, bijv. olati, naar zee; butui, naar de markt; beti, naar de tuin; ebaii, naar huis.

Voorbeelden in zinnen zijn: ipolau olat $i$ malei, hij kwam van de zeezijde naar de landzijde; inuwe lalan olat $i$ fawe, hij keerde weer zeewaarts naar de zee terug; jaboifān butu $i$, ik zou (wilde) naar de markt gaan; nfafala lali dabo $i$, zij plaatste hem onder de waterleiding; mnu pa nagá fakiri isa ilalau olat $i$, niet zo lang daarna een fakir ging zeewaarts naar de zee. Op dit $i$ valt steeds enige nadruk.

De grondwoorden $l \bar{i}$, lau, lei, mul en talíl kunnen verbonden worden met de elementen ma-, la- en po-. Zo ontstaan:

100) M. J. van Baarda, I.eiddraad bị het bestudeeren van 't Galela'sch dialect (1908), p. 139. 
malī, hierheen, herwaarts.

lalī, daarheen, derwaarts.

polī, daarginds.

$$
\begin{aligned}
& \text { malau, hierheen, her- } \\
& \text { waarts, aan de zee- } \\
& \text { zijde. }
\end{aligned}
$$
lalau, daarheen, der- waarts, aan de zee- zijde.

polau, ginds aan de zeezijde, aan zee. malei, herwaarts aan de landzijde.

lalei, derwaarts aan de landzijde.

polei, ginds aan de landzijde.

mamúl, herwaarts naar binnen, matalil herwaarts naar buiten, achter. voor.

lamúl, derwaarts naar binnen, natalil, derwaarts naar buiten, achter.

pomúl, daar binnen, achter. voor (staat wel voor latalil). potalil, daar buiten, voor.

Lalī re malī, der- en herwaarts; lalau re lalei, derwaarts naar de zeeen naar de landzijde.

Voorbeelden van verbinding met pers. vnw, zijn:

ja poli, ik daarginds; au mali, gij herwaarts; $i$ polei, hij ginds aan de landzijde; ame natalíl, wij (excl.) naar buiten; it lalei, wij (incl.) derwaarts aan de landzijde; meu pomúl, gijl. daar binnen, achter; si potalil, zijl. daar buiten, voor; Iaf, au mali , it lali tenda na! Iaf, gij hierheen, wij daarheen naar de winkel! $i$ pomúl kamal loló, hij is binnen in de kamer; jaiseli pojangai poli nim ebai $i$, ik heb gisteren daarginds in uw huis gegeten; fare dtjältjali lalei, vervolgens roeiden zij aldoor derwaarts naar de landzijde; fare wawai tasiá bodfajangis si polei ailoló, vervolgens die kinderen zouden zich laten verdwijnen aan de landzijde in het bos; dem waga isa njeli malau, zij zagen een cocosnoot, hij dreef stroomafwaarts herwaarts naar de zeezijde; fare namjaling lalau olat $i$, vervolgens hij dreef derwaarts naar de zee; taga bebe na ntizua polau olat $i$, toen pas de eend plantte aan de zeezijde aan zee; mtofnga msung mamúl gagau taie, probeer binnen te komen herwaarts binnen deze plaats; intjung lamúl ebai loló, hij ging naar binnen derwaarts in het huis; natalíl nagá nem $i$ plu isa, derwaarts buiten zag hij maar een veer; fare ntotoláng potalil na, vervolgens hij zat daar buiten; fare dopa lali re mali, vervolgens vlogen zij der- en herwaarts.

Verkortingen van matalíl, natalíl en potalíl zijn waarschijnlijk: matā, $n a t \bar{a}$ en potă. Enige voorbeelden hiervan in zinnen zijn: intjapang pomúl ebai loló matā, hij kwam binnen uit het huis herwaarts naar buiten; ai aisá ntub natä waja tja, een boom groeide derwaarts buiten die 
rivier; smat( $\breve{e})$ nparo potā bazea tja, iemand klopte daar buiten op de deur.

Verdere voorbeelden van bijwoorden van plaats in zinnen zijn : kamasefa tau! au mantjawa? ja taine, djou, kamasefa die gij, waar zijt gij ? ik ben hier, heer; wōl senen bonlàfo mantane, Maandag zal hij hier aankomen; $i$ taine, hij is hier; saja lālo enmanā, daar zijn velerlei bloemen; manā smat lālo, daar zijn allerlei mensen; amdel luā?, waar gaat gij heen?; amfān mantjawa?, waarheen gaat gij ?; nalas manā, het is daar dichtbij; lau tu, zeer ver; djou, au mantjazea malī?, heer, vanwaar komt gij hierheen; kapal ta bontjaplo $i$ tja $i$ manā?, waar is het schip, waarop hij zich inschepen zal?; amkaule ahai tiná, waaraan houdt gij daar vast?; induri puis lolas guguo tja nap, hij daalde van de uitloper van het gebergte naar beneden; meuffän nais re ffän nap, gij gaat naar boven en naar beneden, gij gaat op en neer; meufpea nais re fpea $n a p$, gijl. gaat naar boven (d.i. van Buli naar het Noorden) en naar beneden (d.i. van Buli naar het Zuiden); jaipea nais Waisumo, ik ga naar Waisumo; ampea nap Bukumatiti, gij gaat naar Bukumatiti; intjub $i$ nais maglo, hij tilt hem op naar boven op zijn schouders; itekakamor pilú: pao mali wela, pao mali balit, wij hebben twee handen: één rechts en één links; bodut wawai tja nais Batawi, zij zullen (willen) dat kind naar Batavia brengen; jailàfo nais Walanda paubé, ik ben nog niet in Holland geweest; smat tja nmaraparil nap rwaja loló, die man hij kwam naar beneden in het water te vallen; besi tanlera nais $(\breve{e})$ re $n a p$, ijzer, dat zich op en neer bewoog; infän natā, hij ging naar ginds; guā mane manā?, is daar een weerwolf ?; pua peo ta nanai tja nmantjazera?, waar zijn die boontjes van zoëven?; aitotaf ta puis langit $i$ naläl, de sterren boven aan de hemel zijn vele; itetfonfonlo mantaine su,

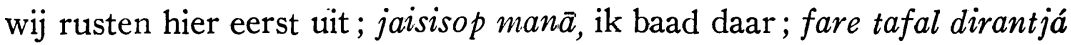
tadlita mali diriring $i$, en enige tekeningen, die aan de wand hangen (die zij aan de wand kleefden, plakten); meu malī tfän lalī tenda $i$, komt gijl. herwaarts, wij gaan naar de winkel; fare nem fun isa pāp waja loló bená, vervolgens zag hij nog een hond beneden in het water; nfān lali smat ta noi-fun tja ni ebai $i$, hij ging derwaarts naar het huis van de jager; inopa nais ebai aisá ni jataf popó, hij vloog naar boven op het dak van een huis; jab isa nopa puis mumuang loló, een arend vloog boven in de lucht; mantane mumis nalāl tu, hier zijn zeer veel muskieten.

B. Bijwoorden van tijd.

Bijwoorden van tijd zijn: taine, tane, nu, heden; wōl taie, deze dag, heden, thans; dòma, morgen ; sema, ochtend, des ochtends; dòma sema, 
morgenochtend; sema lele, 's morgens vroeg; wōl pusa, een dag, eens; oplú, overmorgen; optól, optjól, overovermorgen; opfát, over vier dagen (lett. vier nachten); wōl putjuping, dagelijks ; wōl pusa wōl pusa, elke dag, dagelijks; popei, gisterenavond, vannacht; pojangai, gisteren; popluai, eergisteren; poptjòlai, eereergisteren; dòram pusa dòram pusa, iedere nacht; wōl lāl, op de middag (12 uur); wōl-wōlo, overdag; dòròmo, bij nacht, des nachts, van dòram, nacht; opfapaluan, middernacht (12 uur); polau plangan, op zee licht, \pm 5 uur 's morgens; pota mdòma, daar buiten morgen, vóór de morgen, \pm 5.30 's morgens; bang tjutjuping, zo nu en dan; nanai, zoëven; po, nieuw, pas; sutaga, nu pas; taga, pas, dan pas; nanai sutaga, zoëven pas; tuba, vroeger, voorheen; mesamúl, later; mesamúl taine, nu, tegenwoordig; mnú, lang (v. tijd) ; mnú pa, niet lang van duur, kort daarop; waktu (uit het Mal.), tijdens, toen; tempo (uit het Mal.), tijdens, toen; meas be, toen; tatboboi, dat wij vóór ons hebben, aanstaande; tanmaralapis, dat verleden is, verleden; malinging, namiddag; malinging leo, laat in de namiddag; tò, al, reeds; $s u$, eerst; lāl, dikwijls; lāl $p a$, niet dikwijls,

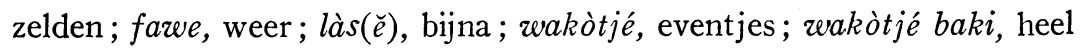
eventjes; loman, lomantá, straks ; salang (Mal. sědang?), juist, van pas, terwijl; garànja be, plotseling, onverwachts; taun pes musun, altijd, voortdurend, jaar in jaar uit; malan, voortdurend, van alan, op een rij zetten; babnga paubé, eenmaal nog niet, nooit; faututi, zonder ophouden,

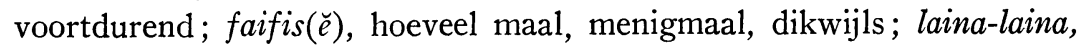
langzamerhand.

Vragend zijn: mafise, wanneer (toekomend); opfis, wanneer (toekomend); popisei, wanneer (verleden).

Voorbeelden van bijwoorden van tijd in zinnen zijn: wōlwōlo ngangā tiná laisarea demem pa, overdag de uilen alsof zij niet zien (kunnen); taine imat mali ikamnutup, nu ik sterf aan ik verdrink; popei ja re hmak re nhjēk-si ktotoláng, gisterenavond ik en mijn ouders wij zaten; jaiseli pojangai poli nim ebai $i$, ik at gisteren daar in uw huis; fen ta nanai tja ilua?, waar is de schildpad van zoëven?; nanai sema taga ipaling ifarera lali dabo tja, zoëven vanmorgen pas ik was opgestaan, ik liep hard derwaarts naar de bron; fare wōl pusa wōl pusa karung tja nfänjo $i$ nmajana, vervolgens iedere dag de zak hij gaandeweg hij licht (werd gaandeweg lichter); wōl pusa tatalē tja npeka guratji, eens (op zekere dag) de kip legde goud (gouden eieren); sema lele tatale mān tja nkuku, 's morgens vroeg kraait de haan; tok faifis taine?,

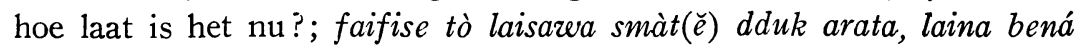
arata tja namjangis fawé, dikwijls al gelijk de mensen een schat ver- 
krijgen, aldus ook die schat verdwijnt weer; meas be gokgok tja nlònga fum tja ni maumauting na, toen de kraai de woorden van de hond hoorde; bo mesamúl mati mfasosal na, opdat gij later geen spijt hebt; lahnga bená matjang isa nlònga mumis lio nalas mali kanjo na, eens ook een tijger hoorde muggen-gezoem dichtbij zijn oren; gabe smat bodiāwa kajāng fatoal be, bang tjutjuping na riri sosare na sāl, denabé dmiskin $t u$, indien de mensen willen zoeken gauw rijk te zijn, zo nu en dan is hun werk verkeerd, totdat zij zeer arm zijn; fare matjang tja nloloman smat tja mnu $t u$, vervolgens die tijger wachtte heel lang op de man; garànja be nem smat isa, eensklaps, plotseling zag hij iemand; wakòtjé baki ndumi kopolau ni labang, in een ogenblik, onverwachts geraakte hij in een spinneweb; dlàfo pnu tja paubé, zij waren nog niet in het dorp aangekomen; mlalaman wakòtjé su, wacht eerst eventjes; taga nmat po, zoëven pas is hij gestorven; amekem bàhnga paubé, wij zagen nog niet eenmaal, nooit; mafise bonfän?, wanneer zal hij gaan?; opfis kapal tja nlàfo mantaine?, wanneer komt het schip hier aan?; popisei au mali, djou?, wanneer zijt gij herwaarts gekomen, heer?; infän popisei?, wanneer ging hij ?; tatuba na induk fafual kamasefa isa, vroeger hij vond een kamasefa-nest; mnu pa nagá smat tanojoi fun tja ntjung mali ni ebai $i$, niet lang daarna kwam de jager zijn huis binnen; dfakubela mnu okòtjé tò, zij hadden elkaar al een beetje lang bevochten (v. hanen).

\section{Bijwoorden van causaliteit.}

Bijwoorden van causaliteit kent het Bulisch slechts weinig; men bezigt tegenwoordig dikwijls sababe (Mal. sěbab) gevolgd door een aanwijzend of vragend vnw., bijv. sababe ahai, waarom; sababe ahai bawa kamal tja nmasalawe? sababe tiná, waarom staat de kamerdeur open? daarom.

Oorspronkelijk Bulisch zijn: gabetá, daarom, daardoor, dientengevolge, dat zo zijnde, bijv. gabetá Setan tja ilalī Harea $i$ na, dientengevolge, daarom ging de Satan derwaarts tot Eva; gabetá nwatja ja mafia, daardoor las hij goed; sababe ngali ja gabetá ikafèna $i$, omdat hij mij hielp, daarom kon ik het; pei aha ga, waarom maar?; pei aha ga au malī, waarom komt gij hierheen?; pei aha ga au lali tiná, waarom gaat gij daarheen?; pejasa, pesa $=$ pei aha, waarom ; ga, daarom, daardoor; bebe na mumat tja njālo i ga enpa, die van de eend de branding nam ze, daardoor waren zij er niet; pei laina, dat zo doende, daarom, daardoor; pejasa gabe ja fuwe fdumi mali fawe?, waarom keert gij 
allen weer derwaarts terug?; gabetá Djou Lahatala bontjoba si, daarom wilde de Here God hen beproeven; pei aha ga ambarani mfatjòtjòma waja taboidom $i$ taie?, waarom zijt gij brutaal, gij vertroebelt dit water, dat ik zou willen drinken?; pei laisawa (= pei aha ga) jaidarawa au, waarom zou ik je beliegen?; gabe i laina ibonmat fare mean ja, daarom laat hij sterven en verzorgt gij mij; gabe laina welisā ipun nok taie betò, daarom het is goed ik dood slechts deze aap.

D. Bijwoorden van hoedanigheid en hoeveelheid.

Vele adjectieven kunnen ook als bijwoord van hoedanigheid optreden, bijv. ntjenga na nenèna pa, hij verblijdde zich niet weinig; jaikean $i$ ta mafia, ik verzorgde hem heel goed.

Verder heeft men: laisawa (lai + sawa), hoe, alsof, gelijk; laina $($ lai $+n a)$, aldus, zo, zoals; laitane (lai + tane), aldus dit, zo; laina tò $(l a i+n a+t o ̀)$, zo is het; laina bená, ook die, dat zo; laina-laina, hoe langer hoe meer; be, ook, slechts, maar; isa bé, één slechts; tutuling, zelf, alleen ; baki, enkel, slechts, voortdurend, altijd; parasadja (= Mal. pěrsahadja), om niets, ijdel; sadja (= Mal. sahadja), slechts, enkel; pore, slechts, maar; nane, behalve, uitgezonderd; nane pore, alleen, slechts; nane bé, alleen, slechts; renta, uitsluitend; ga, het is immers zo, niet waar?, immers, maar wel; nagá, dat slechts, maar toch; gabe, ook slechts; subé $(s u+b e)$, nog, eerst ook; bereā, als het maar; gabe renta, behoorlijk; kurang (= Mal. kurang), minder; re gle, meer; foloi (uit het Tern.), meer, zeer, veel, erg; wela, meer, meer dan; dadiā, sterk, enkel, erg; okòtjé, weinig; èsa, nèsa, anders; leo, zeer (klein); tu, zeer (groot); las, bijna; fazé, nog, weer; bakbako, enkel, alleen; mtoal re meas, snel en langzaam; fafilifān, langzaam; faitji, een beetje, weinig, gering ; fasefat, rechtdoor ; famt $\bar{u}$, vast, sterk; fatutua, zekerlijk; fakòtjé wakòtjé, een beetje, weinig, gering.

Vragend zijn: sifis, hoeveel zij?; safis, hoeveel zij, stuks?; aifis, hoeveel stuks?; faifis, hoeveel maal?

Voorbeelden in zinnen zijn: sema lele tatalē mān tja nkukulaisazea ibonlòlol it, 's morgens vroeg kraait de haan alsof hij ons wil wekken; inu laitane, hij sprak aldus; laina tò, zo is het; laina bená gabe dfaijā$l j \bar{a} l$, aldus ook indien ze een bruid naar het huis van de man brengen (leiden); laina-laina ni nafsu ibon-jāl $i$, hoe langer hoe meer was het zijn begeerte hem te willen nemen; jaibasam laina bená, ik gevoel het ook zo; tjamalele tja nbisa bená, de tjamalele (s.v. slang) is ook giftig; jatenok tazearai nowil be, mijn jongste broer heeft ook koorts; molang 
be au, je hebt maar gelijk; ebai kòrikòri aisá bubuláng nbaki, een klein huis, het is altijd maar enkel (geheel) wit; nane pore wawai sakola pangkat diranfát dlefo mali kartas, slechts de schoolkinderen in de 4e klas schrijven op papier; gabe bersi pa nane dtjisi, als het niet schoon (zuiver) is, filtreren zij het maar; wōl tja renta npopolulu, de zon is uitsluitend slechts rond; jaikòrikòri subé, ik ben nog klein, toen ik nog klein was; gabe laina bereā, indien dat dan aldus is; na ān na kurang $p a$, zijn eten is niet weinig; bàhnga-bàhnga gabe renta wawai sakola dut mangsī, elke dag (dagelijks) het is behoorlijk de schoolkinderen brengen griffels mee; pore isa bé, één slechts; gabe $i$, hij ook slechts; nòni Buli bubuláng dadiā, een geheel (enkel) witte (blanke) Bulische jongejuffrouw; jàfasa re gle, meer dan tien; silú zela isa, twee is meer dan één; Mabantji ddarān na foloi, de Mabarezen zijn zeer onbeschoft; pinge ni ngai pusa nfaeda ja foloi, één rijstkorrel heeft mij meer waarde (nut); amenanam sumu tja namlaman tu, onze put is zeer diep; mamàgal $t u$, zeer groot; bersi famafia, heel schoon, zuiver; msai pa

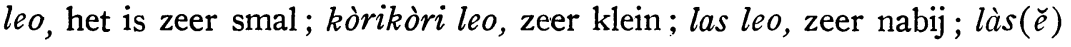
bo sen pitól, bijna zou 't drie cent zijn, d.w.z. het is $2 \mathrm{1} / 2$ cent: mbalat $i$ famtū, bind hem stevig vast; djara gogō tja nfānn na meas, het zwarte paard loopt langzaam; fān filifān, langzaam lopen; dòma taga isakola fawé, morgen pas ga ik weer naar school; ni pugau lebat guratji tadtintinka intan bakbako, haar haarspeld is van goud, dat geheel ingelegd is met diamanten; tok faifis?, hoe laat is het?; fare mnu pa nagá mani tja ntotongo ai tja fawé, en niet zolang daarna de vogel zat weer op die boom; dfakubele mnu okòtjé tò, zij hadden al een beetje lang gevochten (de hanen); lobor kòrikòri tja nenèna leo fawé, onze pink is weer zeer klein (kleiner dan de andere vingers); amdel luā mfān fatoal bená?, waar gaat gij heen, gij loopt ook maar zo snel; mòtje nak pinge wakòtjé, geef mij een weinig rijst; waja tja nfifànas subé, het water is nog lauw.

Bijwoorden van hoedanigheid en hoeveelheid worden ook gebruikt in gevallen waarin het Ned. een comparatief of een superlatief gebruikt, bijv. ja re au tfarera mtoal be ja, ik en gij wij lopen hard, vlug ook ik, d.w.z. ik loop vlugger dan gij; sababe nfarera ja mtoal tu, omdat hij heel erg hard liep; fare ntjenga nenèna pa, vervolgens hij verheugde zich niet weinig, d.w.z. hij verheugde zich uitermate.

\section{E. Bijwoorden van modaliteit.}

1. Bijwoorden van bevestiging: io, $i a$, ja; djou, tegenover meerderen, het betekent lett. „heer”, het zal wel uit het Tern. overgenomen 
zijn; $n n$, ja (minder beleefd; is eigenlijk een soort toestemmende interjectie); tutuo, zeker, werkelijk van $t u$, zeer; osetane, zekerlijk, waarlijk, stellig; $p a g a$, niet waar? (eigenl. ontkennend, ook in bevestigende zin gebruikt); renta, zekerlijk; ga, wel.

Voorbeelden in zinnen zijn: fare luf tja ntjanglo: $n n$ ! (io), en de muis antwoordde: ja; fare Iaf nu osetane jaboiduk $i$, en Iaf zeide: zekerlijk ik zal hem krijgen; ampande tutuo bená, gij zijt ook werkelijk knap; ga idjaga djou tja ni pelang tai, wel ik bewaak deze prauw van de heer; gabe ise npei karadjäng pusa nafèna pa, renta mesamul na ndadi laisazea sapi re karkar tja, indien iemand een werk doet, dat hij niet kan, zekerlijk later gaat het hem als de koe en de kikvors; gabe

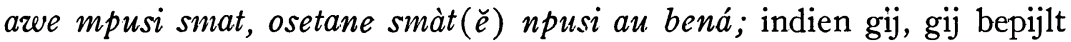
iemand, zekerlijk men bepijlt jou ook; pifát failú pizwai pa ga?, $2 \times 4=8$, niet waar?; mna pa ga?, het is zoet, niet waar?; smo be ta lio pa ga?, zijn bek geeft geluid, niet waar?

2. Bijwoorden van ontkenning: $p a$, niet; pene, neen; pantò, niet meer; paubé, nog niet; mati gevolgd door ná, (nadrukswijzer) wil niet (vetatief).

Voorbeelden van gebruik in zinnen zijn: pene laina pá, neen, zo is het niet; intamaga nafèna pantò, hij kan geen sirih-pinang meer kauwen; ingahnjo ise? Iaf? pene, hoe heet hij? Iaf? neen; diàfo pnu tja paubé, zij waren nog niet in die plaats aangekomen; jaijas iduk $p a$, ik kan niet zwemmen; gu tja re fitjo pa, re faio pa fare re jaljalfo pa, de slang heeft geen poten, geen vleugels en geen vinnen; janak dalima tja nmara paubé, mijn granaatappels zijn nog niet rijp; amekem bahnga paubé, wij hebben het nog nooit gezien; mati mlois ná, wil niet stelen; mati msia smom ná, open je bek niet.

3. Vragende bijwoorden: ga, toch, maar; bijv. peisa ga ditja amua lukam i?, waarom noemt gij Spaanse peper toch lansat?; lai, dat achter de zin wordt geplaatst; het stelt de vraag enigzins onzeker; dit of dat?, bijv. māni lai, mapingi lai?, is het een jongen of een meisje?; ngahnjo ise? Lea lai? pene, hoe heet zij? Lea? neen; tutuo lai?, zou het waar zijn?; waja ta pau na ddòmi lai?, water, dat stinkt, drinken ze dat?; pa ga, niet waar?; ise ni ebai tja ga?, wiens huis is dat toch?; pilim failú, pifise ga?, $2 \times 5$, hoeveel is dat wel?

4. Bijwoorden, die een twijfel uitdrukken : wahle, wellicht; laha, misschien, of. $\mathrm{Zij}$ komen dikwijls samen voor; in dat geval staat wahle aan het begin en lahá aan het eind van de zin.

Voorbeelden zijn: ngahnjo ise? Anna lahá, Maria lahá?, hoe heet zij ? Anna misschien, Maria wellicht?; nòke tau, wahle mtō mreatja pa laha!, 
vriend, die gij, wellicht kunt gij niet lezen!; wahle smat jàfasa tadpele sepa, misschien zijn er tien mensen, die voetballen; uahleo isa ni umur na wahle taun faijàfawai, een oudje, wiens leeftijd misschien 80 jaar was; wahle nim tiwi pa lahá, misschien hebt gij geen geld!

5. Bijwoorden die een wens uitdrukken: naga, als maar; bijv. fare woi tja nu: ja nagá isunai ja gare ja re i kmauting wakòtjé su, en de haai zeide : als ik haar maar bereikte, dan ik en zij, wij praten eerst een weinig. 


\section{HOOFDSTUK VII.}

Voorzetsels.

Het Bulisch is evenals vele andere Indonesische talen arm aan voorzetsels. Het bezigt dikwijls bepaalde werkwoordsvormen, waar het Nederlands een voorzetsel gebruikt.

Een woord, dat uitsluitend als voorzetsel voorkomt, is mali ${ }^{101}$ ). Het kan op velerlei wijze in het Ned. vertaald worden, zoals met: van, tegen, op, in, aan, te, naar, uit, bij, tot, tussen, onder.

Omtrent de vorming van mali kan ik geen nadere verklaring geven. Het is niet onmogelijk, dat het uit $m a+l i$ bestaat. In andere ZuidHalm. talen komt het niet voor. Daar vindt men meestal po met gelijke betekenis als mali ${ }^{102}$ ).

Voorbeelden van gebruik zijn: bali tja $d$-jāl mali nau na, de zwam halen ze van de arenpalm; natjutje fitjo mali pāt fare namop, hij stootte met zijn voet tegen een steen en hij viel; mali rakrak patpatan, op het vlakke veld; taga jaigon mali kijai ni tenda na, nu pas ik 'k kocht in de winkel van de Chinees; mali pnu pusa smat silú dpei bet, in een plaats (dorp) twee mensen zij maakten een tuin; nturi tja dfateam $i$ mali obob isa, hun kind zij lieten het achter in een mand; itekakamòr pilú, pao mali wela, pao mali balit, wij hebben twee handen, één aan de rechteren één aan de linkerzijde; fare nfautan mali Nur $i$, vervolgens hij vroeg aan Nur; tuan ntjung mali pnu Buli, mijnheer ging naar Buli (ging B. binnen); fare eta tiná maralapis mali kakamo, en het kapmes viel uit zijn handen; nlònga mumis ngolo lio nalas mali kanjo na, hij hoorde muskieten-gezoem dichtbij zijn oren; fare nu mali Nur $i$, en hij zeide tot Nur; fare dfän na dlàfa mali laling tja ni fapaluan, en zij gingen en kwamen tot het midden van de weg; mali saja ta lālo tiná pore saja mawar ta mafia, onder de velerlei bloemen slechts de roos is de mooiste; ndadi fafajāl pusa mali sili, het wordt een teken voor hen; mai isa be ta mbalas mali au, maar een ook hij vergeldt het aan je; taine mbalas nik mafia ta ipei mali awe na, dit vergeldt gij het goede (mijn goed), dat ik aan u deed?; nau tja ni asal ja läl mali it, de voortbrengselen van de arenpalm zijn vele voor ons.

Mali kan gecombineerd worden met woorden als: loló, binnenste, popó, bovenste, papao, benedenste, onderste, e.d., waardoor uitdrukkingen ontstaan, die als samengestelde preposities kunnen worden be-

101) Wel te onderscheiden van het bijwoord mali, hierheen, herwaarts.

102) Vg1. F. J. F. van Hasselt, Nufoorsche Spraakkunst, p. 50. 
schouwd ${ }^{103}$ ) en die in betekenis overeenkomen met de Ned. preposities in, boven, op en onder.

Voorbeelden zijn: fare mali fafual tja loló na kamasefa wawaio isa $b e$, en binnen in dat vogelnest was slechts één kamasefa-jong; fare ngogàni mali ni kabaja tja loló, vervolgens verborg hij het binnen in (onder) zijn baadje; Koda ntotoláng mali kamal loló, Koda zat binnen in de kamer; mali sosaro isa papapo, onder een matras; fare ngogàni mali awat na papapo na, en hij verborg zich onder de zitplank van de prauw ; sidem lilit pusa mali tapak tja popó, zij zagen een mangga boven op de weg; mali smat( $\breve{e})$ ni ebai fapaluno mawa popó, binnen in het midden van de huizen der mensen; fare-npia mali tapak tja popó, en hij liep hard weg boven op de weg.

Men treft ook andere samenstellingen aan bijv. in zinnen als: Basar $i$ pomúl kamal loló, Basar is binnen in de kamer; intjapang pomúl ebai loló matā, hij kwam van binnen het huis naar buiten; intjung namúl ebai loló, hij ging naar binnen in het huis; jaifateam tabako re tamaga puis medja popó na, ik 'k laat tabak en sirih-pinang achter boven op de tafel; dirantjá tadtjap puis pāt popó, een deel dat zij drukken boven op steen; jab mamàgal tu isa nopa puis mumuang loló, een zeer grote arend vloog in de lucht; tatale mān tja ntotoláng puis pupuang tja popó, de haan zat boven op de nok; kabil tasiá dmarapareil nap waja loló, die beide geiten kwamen te vallen naar beneden in het water; waja mali bòtol tja loló na nlàfo nais sapngo pa, het water in die fles reikte niet tot naar boven de uitgang (de mond der fles).

Over $i$ als richtingaanduider is reeds medegedeeld, dat het door ons voorzetsel ,naar” kan vertaald worden. Voorbeelden zijn nog: ntjung mali ni ebai $i$, hij kwam (ging) naar binnen zijn huis; pota ebai $i$ nik kòro isa mpatpatan puis sosaro popó be, daar in huis een slaaf van mij ligt slechts boven op een slaapbank; wōl pusa fun tja nololau sou tja bodtjeli mali fun tja ni ebai $i$, op zekere dag de hond riep de reiger, zij wilden eten (om te eten) naar het huis van de hond.

$R e$, gewoonlijk een voegwoord met de betekenis van ,en”, treedt ook wel op als voorzetsel ${ }^{104}$ ), bijv. gu tja re faio pa re fitjo pa, de slang met zijn vleugels niet, met zijn poten niet, d.w.z. de slang heeft geen vleugels en geen poten; popolulu tiná re ni marapurus, die balletjes met hun gaatjes, d.w.z. die balletjes hebben gaatjes; pao re pao na re ni garis, aan weerszijden met hun strepen $=$ hebben ze strepen; mali

103) Vgl. S. J. Esser, Klank- en vormleer van het Morisch, II, p. 265 en N. Adriani, Spraakkunst der Bare'e-taal, p. 396.

104) Vgl. N. Adriani, Spraakkunst der Bare'se-taal, p. 397. 
oloan tja ni paseba loló re ni mani ulan ni fafual, binnen in de voorgalerij van het dorpshoofd met zijn zwaluwnesten (zijn zwaluwnesten); ja re tenok pa, ik met mijn broers niet, d.w.z. ik heb geen broers; tetang na re ni baraguna bená?, wij rekenen met zijn nut ook? d.w.z. heeft dat ook nut?; re ni bawa pa, re ni tjalena pa bená, met zijn deur niet, met zijn venster ook niet, d.w.z. het heeft geen deur en ook geen venster; $\bar{a} n$ pusa-pusa re pepeio renta peio $\bar{a} n$, ieder eten met zijn gerei om het te bereiden; re mta, inem $p a$, met zijn ogen, hij ziet niet (hij heeft ogen, hij ziet niet); Djou Lahatala nfakat re $i$, de Here God beraadslaagde met Hem (= Zichzelf); re slubo, met, bij honderden; re jàfo, met, bij tientallen. 
HOOFDSTUK VIII.

Voeg woorden.

Evenals vele andere Indonesische talen bezit het Bulisch slechts weinig voegwoorden; sommige zijn aan het Maleis ontleend ${ }^{105}$ ), bijv. sababe (Mal. sěbab), omdat, wegens; ata, atawa (Mal. atau), of ; bai ....bai (Mal. baik ... baik), of .... of ; salang (Mal. sedang), terwijl.

Verbindende, aaneenschakelende voegwoorden zijn : $r e$, en, met, bijv. hmak re hnjēksi, mijn vader en mijn moeder, mijn ouders; jàfa re tabako, kalk en tabak; män re maping si, ze zijn man en vrouw; pao re pao, aan weerszijden; jàfasa re silú, tien en twee, twaalf ; ja re au, ik en gij; wōl tja nute plangan re mfànas, de zon brengt (geeft) licht en warmte.

Een enkele maal vindt men $d e$ in plaats van $r e$, bijv. wōl de wōl, dag en dag, dag aan dag ${ }^{\mathbf{1 0 6}}$ ).

Soms ook ende (en, zijn $+d e$ ) bijv. respes pao na ende tiwi guratji na dfamamàglo, het halve guldenstuk en het gouden tientje zijn even groot.

Men treft re ook aan verbonden met $i$, hij, zij, het, bijv. tjangkurakura ire bebe dfän dningo bet, de schildpad en de eend zij gingen de tuin zien. Aan ire wordt soms nog het suffix - $a$ toegevoegd, bijv. salilitá irea luftá fare ugamtá, de rode boommier en de muis en het schelpdier.

Het komt ook voor in fare, fareá, en, vervolgens, bijv. lalei fareá maping tja nua ni uattá, naar de landzijde gaande, vervolgens de vrouw zeide tot haar man. Fare komt in verhalen zeer dikwijls voor aan het begin van een zin $^{\mathbf{1 0 7}}$ ), bijv. fare Ali nu laitane, en (vervolgens) zeide Ali aldus; fare tēt tja namsai pa, en dat bruggetje was niet breed (smal); fare ntalko npei lio laisawa kabil ngolo tja bená, vervolgens hij makte na het geluid (de stem), gelijk dat ook van de moedergeit.

Mogelijk zijn fare en fareá versterkingen van $r e$.

Naast re komt voor $g a$, en, vervolgens. Voorbeelden van gebruik

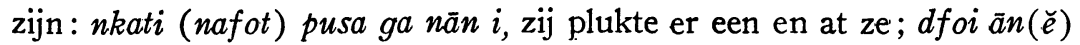
ga dān, zij kookten eten, vervolgens aten zij het; fare $n f \bar{a} n(\breve{e})$ ga nololau hnjē bodān fajau na, vervolgens zij ging en riep haar moeder, willende (om te) eten die aardvruchcten (kaladi, Colocasia antiquorum

105) Vg1. C. A. van Ophuysen, Maleische Spraakkunst, 2e druk, p. 340.

106) Vgl. N. Adriani, Spraakkunst der Bare'e-taal, p. 76.

107) Vgl. Mak. lebaki en het Mal. maka. 
L.) ; ni pajung ga kolano $i$ pa, ni ununaf mai ian $i p a$, hij heeft een zonnescherm en is geen koning, hij is geschubd, maar is geen vis; $j a$ taine ikuahleo tò, ga itjitjoal pantò, deze ik, ik ben al oud en daarom niet sterk meer.

Verder komen voor: bai ... bai (Mal, baik ... baik), bijv. wōl taie mati fpei monara ná, bai meu, bai ntu meu māntji, bai ntu men mapingsi, deze dag wilt dan geen werk doen, gij of uw zonen, of uw dochters. ;

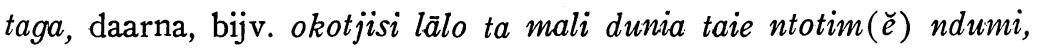
taga Djou Lahatala ndadikan( $\breve{e})$ smat it, toen alles, wat op aarde is, gereed was, daarna pas schiep de Here God ons mensen;

ta tina tò, daarna, bijv. tina tò fare pado na nbersi, daarna was de melaatsheid genezen;

nane, alleen, slechts, bijv. tina nane ai ulu re wa, alleen boombladeren en -wortels;

bená, ook, nog, bijv. bená blewing na enmanā bená, er zijn loophoenders en ook nog duiven.

Tegenstellende voegwoorden zijn:

ma of mai, maar, bijv. maske kokopē, mai mlànga be, of schoon kort, maar hij is ook lang. Men treft ook een enkele maal maitá aan, waarin ta hier wel de nadrukswijzer ta zijn zal, bijv. maita wōl Ahar tja Djou Lahatala wi wōl, maar de Zondag is Gods dag;

ga, maar, toch, bijv. ni pajung ga kolano $i$ pa, hij heeft een pajung, maar toch is hij geen koning;

ata of atawa (Mal. atau), of, bijv. uhngo laisawa kasinā ata laisawa pāt ta sasaletam na, zijn voorkomen is gelijk een spiegel of als een steen, die glinstert; basan na dpeio ebai ni jataf, ata reala, van zijn harige omhulsel der takken maken ze dakbedekking of touw;

lai .... lai, of .... of ${ }^{\mathbf{1 0 8}}$ ). Lai is eigenlijk een vragend bijwoord, doch moet dikwijls door "of” vertaald worden, bijv. djara Batak lai, djara Suba lai, is het een Bataks paard of een Sumbaas; fu diranlú lai dirantól lai ta fān laina, noem twee of drie soorten, die ook zo zijn; janak tatale tolo tiná ndadi lai ndadi pa lai!, mijn kippeneieren zouden ze gelukken of niet!; amfikir laisawa mia tja npande lai npande pa lai, wat denkt gij, die aap is hij knap of niet?

In het Bulische verhaal Woitá, de haai, komt voor laisa dngisa, dan alleen slechts, dat ik niet nader kan verklaren;

nane pore, nane be, alleen, slechts, bijv. jaikem isa pa nane be bereak

108) Vgl. F. J. F. v. Hasselt, Spraakkunst der Nufoorsche taal, p. 49. 
isa, ik zag niets, alleen een bereak (s.v. vogel); amektultje tinta kduk paubé, nane pore wawai sakola pangkat diranfát lai, diranlím dlefo mali kartas, wij kunnen nog niet met inkt schrijven, alleen de leerlingen van de vierde of vijfde klas schrijven op papier;

pore, alleen, slechts, bijv. mali saja ta lālo tiná, pore saja mawar ta mafia fare pau ja mafia, onder al die verscheidene bloemen, alleen de roos is mooi (de mooiste) en zijn geur is lekker.

Redegevende voegwoorden zijn: gabetá, dientengevolge; renta, omdat; ga, omdat; sababe (Mal. sěbab) omdat, wegens. Voorbeelden zijn: fare ni del tasiá damlifa $i$, sababe npa karung ta tebteb tu tja, vervolgens zijn makkers lachten hem uit, omdat hij pikulde de zak, die zeer zwaar was; renta ja mān ja fänfān ja, omdat ik man ben, ga ik; jaboifān ga ulan nmamàgal, ik zal gaan, want de regen wordt hevig; fare aizeani silú tasiá dfatotolè, gabetá kabil tasiá dmaraparil nap waja loló, vervolgens die twee geiten werden boos op eikaar, dientengevolge zij vielen naar beneden in het water.

Onderschikkende voegwoorden zijn: laisawa, alsof, hoe, gelijk, bijv. sema lele tatale mān tja nkuku, laisawa ibonlòlol it, 's morgens vroeg kraait de haan, alsof hij ons wil wekken.

Doelaanwijzend is bo, opdat, bijv. mafia be mpei jaja, bo mati nik kabil na dereis anam bet tiná ná, het is maar goed gij maakt een heg, opdat mijn geiten uw tuin niet vernielen; welisá itetgali smat tanduk susa, bo mati mesamúl susa tja neta it ná, laat ons de mensen helpen, die moeite hebben, opdat die moeite later ons niet treffe.

Voorwaardelijk is gabe, als, indien, bijv. gabe ise ngali ja pa, osetane boimat, indien niemand mij helpt, zal ik zeker doodgaan; gabe laina bereá nim del isa tandarawa ja, indien dat zo is, dan heeft een van je makkers mij bedrogen; gabe ndahle it, botlònga $i$, indien hij ons nadert, zullen wij hem horen.

Tijdbepalend is denabé, totdat, bijv. fare npupi woi tja, denabé nmara, vervolgens zij roosterde de haai, totdat hij gaar was; fare dfapunpun, denabé laflaf tiná ntjapang, vervolgens sloegen zij elkander, totdat het bloedde. 
HOOFDSTUK IX.

Tussenwerpsels.

De meest gebruikelijke tussenwerpsels zijn :

adede!, tjekede!, uitroep van pijn of verdriet;

seni!, uitroep van deelneming;

$e$ !, drukt verrassing uit, bijv. e! males tau!, he, meisje die gij!; $e$ ! iduk au!, he, ik heb je!;

$i$ !, geeft afkeer te kennen;

gare!, drukt verbazing uit in afkeurende zin;

elele!, drukt verbazing uit;

tje!, geeft afkeuring te kennen;

ehe?, is een vragend tussenwerpsel;

jo! ajou!, zijn aansporende interjecties;

are!, pas op!, bijv. are neka e!, pas op jongere zuster!;

$n n !=i o !, \mathrm{ja} !$ (toestemmend) ;

$i$ i! tjia!, ja!;

us, us! bure, bure!, brr!;

kring, kring!, nabootsing van het geluid, dat kippen maken 


\section{TEKSTEN.}

De volgende teksten heb ik gekozen uit een kleine verzameling, die ik verkreeg door enkele kwekelingen en andere leerlingen van de school te Buli de verhalen te laten opschrijven, die zij van hun ouders of anderen hadden gehoord.

Het trof me in die teksten, dat zij de vervoegde werkw., die met een medeklinker aanvangen en waarvóór de korte vorm van enkele pers.vnw. komen, (bijv. mdom, gij drinkt; ndom, hij drinkt; tdom, wij drinken (incl.); kdom, wij drinken (excl.); ddom, zij drinken), steeds met een $e$ vóór dat pers.vnw. schreven, dus emdom, endom enz.

Het eigenaardige in de dingding (kinder-, wiegeliedjes) is, dat daarin allerlei critiek op de baby's wordt geuit. Dit hangt samen met de vrees, dat de aandacht te veel op de kleinen zal worden gevestigd. De kindersterfte was te Buli zeer groot, wat aan de invloed van allerlei boze machten en krachten werd toegeschreven. 


\section{Woitá.}

Malu pnu isa mapíng isa balo isa i re ntu silú ; isa mapíngi isa māni. Ta mapíngi tja tauatí fare ngahnjo Nur; ta māni tja tawawaí fare ngahnjo Patendibor. Riri gogaho pa is pa laisadngisa ${ }^{1}$ ) wōl pusa wōl pusa dpei be bét.

Bàhnga laitane mapíng balo tai ilalei bèti, ntu silú tasiá teteam polau ebaii. Mnu pa nagá smat isa ni mef woi ${ }^{2}$ ), sababe tiná ngahnjo Woi, ipolau olati malei, fare ilalì mapíng balo tja ni ebai, fare nfautan mali mapíng balo tja ntu silú tasiá, nu laitane : ,Hnjē meu tja ndéllua ?” Fare Nur ntjanglo: „Aje ilalei bèti”. Fare Woi tja nu: ,Ja nagá isunai ja, gare ja re i kmauting wakòtjé su". Mnu pa nagá Woi tja nuwe lalau olati fawé.

Wōl tja neilei nap ${ }^{3}$ ) taga hnjēri tja nuwe. Fare Nur nfabinga Woi tja ni maumauting na nu laitane: „Nanai Woi tja nu, gabe ntjuna au, gare i re au maumauting wakòtjé su". Hnjēri tja nlònga laina fare inonau Nur ndarawa fare ndela Nur pa. Sema tje hnjēri tja ilalei bèti fawé. Mnu pa nagá Woi tja imalei fawé, nfautan: „Nur ga hnjē meu tja ndéllua ?” Fare Nur ntịanglo: „Aje ilalei bèti fawé”. Fare Woi tja nu: ,Ja naga isuna i ja gare ja re i kmauting wakòtjé su”. Tina tò fare Woi tja nuwe lalau olati fawé.

Wōl tja neilei nap hnjëri tja nuwe lalau ebai fawé. Fare Nur nfabinga hnjē nu laitane: „Aje, nanai Woi tja imalī fare nfautno au fawé”. Tina tó fare mapíng balo tja ndela ntu tja, fare nuta akal bonpun Woi tja, sababe Woi tja ulo na bonfasawa mapíng balo tja. Mapíng balo tja nuta akal laitane fare nu mali Nur i nu laitane: „Nur, gabe mdòma Woi tja imalei fawé, mu ja lalei bèti”. Sema tja dòròram

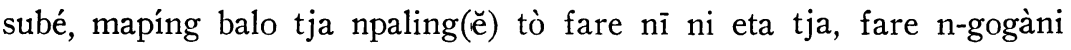
mali sosaro isa papapo. Mai mulaen tan-gogàni paubé na, npei tabako re tamaga fare wo, nfateam puis medja isa popó ; fare nfatnawe Nur: „Gabe wakòtjé Woi tja imalei fawé, mu jalalei bèti fawé, mfabingai

1) laisa dngisa. Volgens de Heer Ds. K. A. Bot, een van mijn opvolgers te Buli, moet het geschreven worden: laisa dngisa en zou het betekenen "slechts zijlieden". Degene, die het verhaal schreef, een Buliër, vertaalde het in het Maleis met "hanjalah"; daarom vertaal ik het met: „,niet anders dan”, ofschoon ik de uitdrukking niet ken, noch haar nader kan verklaren.

2) smat isa ni mef woi. De Heer Bot deelde mij mede, dat mef in de verhalen betekent: „die tot moeder had”, „van geboorte”. Een van mijn vrienden te Buli vertelde me, dat een van zijn voorouders bevallen was van een kind en een varken; daarom at hij geen varkensvlees.

3) wōl tja neilei nap. Ik kan dit niet verklaren; het betekent: de zon is bijna ondergegaan, het is bijna 6 uur. 


\section{De Haai.}

In zekere plaats bevond zich een weduwe met haar twee kinderen; het was een meisje en een jongen. Het meisje was de oudste, haar naam was Nur; de jongen was de jongste en heette Patendibor. Hun dagelijks werk was niet anders dan elke dag te tuinieren.

Op zekere dag ging deze weduwe naar de tuin; haar beide kinderen bleven thuis. Niet lang daarna kwam er iemand, die van een haai afkomstig was, en daarom Haai genoemd werd, van de zeezijde landwaarts en ging naar het huis van de weduwe. Vervolgens vroeg hij aan de beide kinderen der weduwe, aldus zeggende: „Waar is uw moeder heengegaan?” En Nur antwoordde: „Moeder is naar de tuin”. De Haai zeide: „Als ik haar aangetroffen had, ik en zij wij hadden stellig eerst wat gepraat!" Spoedig daarop keerde de Haai weer naar de zee terug.

Toen de zon bijna was ondergegaan, keerde hun moeder pas terug. En Nur deelde de woorden van de Haai mede, zeggende aldus: „Zoeven de Haai zeide, indien hij $\mathfrak{u}$ aangetroffen had, zeker hij en $\mathfrak{u}$ hadden eerst wat gepraat". Toen hun moeder dit aldus hoorde, meende zij, dat Nur aan het liegen was en zij geloofde Nur niet.

De volgende morgen ging hun moeder weer naar de tuin. Niet lang daarna kwam de Haai weer naar de landzijde en vroeg: „Hé, Nur, waar is je moeder?” En Nur antwoordde: „Moeder is weer naar de tuin!" En de Haai zeide: „Als ik haar aangetroffen had, ik en zij, wij hadden stellig eerst wat gepraat". Daarna de Haai keerde weer naar de zee terug.

Toen de zon bijna was ondergegaan, hun moeder keerde weer terug. Vervolgens Nur deelde haar moeder mee, zij zeide aldus: „Moeder, zoëven de Haai was hier en hij vroeg naar u". Daarna de weduwe geloofde haar kind en bedacht een list, om de Haai te doden, omdat de Haai met die weduwe wilde trouwen. De weduwe bedacht een dusdanige list en zeide tot Nur, zeggende aldus: „Nur, indien morgen de Haai weer hierheen komt, zeg dan, ik ben naar de tuin".

In de morgen, het was nog donker, stond de weduwe al op en sleep haar kapmes en verborg zich onder een slaapplaats. Maar tevoren, toen zij zich nog niet verborgen had, maakte zij tabak en sirih-pinang en sagoweer (palmwijn), zij liet het alles achter op een tafel en beval aan Nur: „Indien over een poosje de Haai weer hierheen komt, zeg dan, ik ben alweer naar de tuin; gij geeft hem kennis, gij zegt, ik heb tabak en sirih-pinang achtergelaten op de tafel".

Niet lang daarna kwam de Haai weer en hij vroeg aan Nur: „Nur, 
mu jaifateam tabako re tamaga puis medja tja popó na”. Mnu pa nagá Woi tja imalei fawé, fare nfautan mali Nur i: „Nur ga hnjē meu tja ndélluá ?" Fare Nur nu laitane, aje ilalei bèti fawé; fare aje nfateam tabako re tamaga fare wo puis medja tja popó na, untuk anam". Woi tja nlònga laina fare ntjenga nu laitane: „Laisawa jaiduk salaka tanbabai". Tina tò fare Woi tja n-jāl tabako re tamaga na fare wo na. Fare ntamaga fare ntjoraf tabako. Mnu pa nagá ndom wo na nmoni fare tamaga na nmasisei ${ }^{1}$ ), fare namtuli mali babala ${ }^{2}$ ) na popó

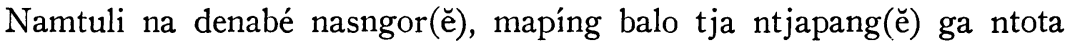
Woi tja glao tja, denabé namorit, fare Woi tja nmat. Fare mapíng balo tja npei fafa isa fare npupi Woi tja denabé nmasa. Sema tja mapíng balo tja ulo na sanange tò, fare ilalei bèti fawé. Mai mulaen ta ilalei paubé na nfatnawe mali Nur, nu laitane: „Nur, gabe wakòtjé Patendibor ntangis nulo ān, mjāl Woi tja ni wàngat, ata momami lai, ata ān nèsa, mati mjāl Woi tja ni maimaio tja ná, sababe tja janàki, boikāni”.

$\mathrm{Nu}$ nfonla fare hnjēri tja ilalei bèti. Nfān na mnu pa nagá fare Patendibor ntangis fare nulo ān. Fare Nur npoi kupa re momami, fare Woi tja ni wàngat na, mai Patendibor ntangis be, nailou pa ān, ta Nur npoi na, fare ntangis be. Fare Nur nfatōtō akal pantò, fare nakikit Woi tja ni maimaio na okòtjé fare nfalepa Patendibor. Tina tò fare Patendibor ntangis pantò. Malinging tja fare hnjēri tja nuwe lalau ebai fawé, fare Nur nfabinga nu laitane: „Aje, nanai Patendibor ntangis fare jaikotjei ān rupa-rupa nailou pa, lomanta jaijāl Woi tja ni maimaio na okòtjé, taga Patendibor ntangis pantò". Hnjēri tja nlònga laina, fare ntolē fare nu laitane: „Gare, jaiku mati fān na woi tja ni

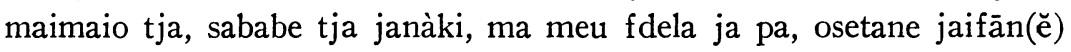
ikowe meu!".

Dòram tja Nur ire Patendibor damtuli tò, fare hnjēri tja npei ān ta bonpo na elan. Dòram sube hnjēri tja nfapepea i ga nfān. Mnu pa nagá Nur npaling fare npapa Patendibor, fare dtagtaga hnjēri tja.

I! ... gabe hnjēri tja nlàfo mali lolo isa, Nur ire Patendibor dlàfo mali memeno isa; gabe hnjēri tja nlàfo mali popo isa, Nur ire Patendibor dlàfo mali lata isa. Denabé dafèna pantò fare Nur nololau: „Aje! aje! mtotoman am!” Fare hnjēri tja nmasie si okòtjé. Fare nfo na sus na mali katop mamàgal isa. Nfo nfonla fare nfān fawé. Fare

1) nmasise $i$, het bedwelmde hem, het maakte hem dronken. Volgens de Heer Bot is masise, bedwelmd zijn door pinangnoot, en zou masese, bedwelmd zijn door allerlei betekenen. (Zie Boelisch-Nederlandsche Woordenlijst, p. 64).

2) babala (Mal. bale-bale), slaapbank. 
waar is jullie moeder toch?” en Nur zeide aldus: „Moeder is weer naar de tuin, en moeder heeft tabak en sirih-pinang en sagoweer voor u achtergelaten op de tafel". Toen de Haai dat hoorde, verblijdde hij zich en zeide aldus: „Het is alsof ik zilver vind, dat aangespoeld is!” Daarna nam de Haai de tabak en sirih-pinang en de sagoweer. Hij pruimde de sirih-pinang en rookte de tabak. Nadat hij de sagoweer gedronken had, was hij dronken en de sirih-pinang bedwelmde hem. Vervolgens hij sliep op de rustbank. Hij sliep, totdat hij snorkte. Toen kwam de weduwe te voorschijn en sneed (hakte) de Haai zijn keel door, totdat hij afbrak en de Haai was dood. Vervolgens de weduwe maakte een stellinkje en roosterde de Haai, totdat hij gaar was.

Die morgen was de weduwe verheugd, vervolgens ging zij weer naar de tuin; eerst, toen zij nog niet gegaan was, gaf zij bevel aan Nur, zeggende aldus: „Nur, indien over een poosje Patendibor huilt willende eten, neem dan van de Haai zijn vlees, of zoetigheid, of ander eten; wil niet nemen van de schaamdelen (v. d. Haai), want die zijn van mij, ik zal die eten!"

Toen zij uitgesproken was, ging hun moeder naar de tuin. Zij was nog niet lang weg, toen Patendibor huilde willende eten. Vervolgens Nur gaf hem rijst en zoetigheden en haaienvlees, maar Patendibor huilde slechts, en wilde niet eten, wat Nur hem gaf; hij huilde slechts. Vervolgens wist Nur tenenenmale geen raad meer en zij kneep met haar nagels een beetje van de schaamdelen van de haai en liet er Patendibor aan likken. Daarna huilde Patendibor niet meer.

Tegen de avond keerde hun moeder weer naar huis terug en Nur gaf haar kennis zeggende aldus: „Moeder, zoëven Patendibor huilde en ik gaf hem allerlei eten; hij wilde niet. Eindelijk nam ik een beetje van de schaamdelen van de haai, toen pas huilde Patendibor niet meer". Toen hun moeder dat hoorde, was zij boos en zeide aldus : „Hoe is het mogelijk! Ik zeide toch: wilt niet eten de schaamdelen van de haai, want die zijn voor mij; doch jelui geloven me niet; zekerlijk ik ga, ik verlaat jelui!"

Dien avond, Nur en Patendibor sliepen al, vervolgens hun moeder bereidde eten, dat zij tot haar leeftocht wilde maken. Het was nog nacht, toen zij daarmee klaar was en vervolgens ging zij weg. Niet lang daarna stond Nur op en droeg Patendibur op haar schouder en zij volgden hun moeder. $O$ wee! indien hun moeder een baai (inham) bereikt had, Nur en Patendibor kwamen aan een kaap; als hun moeder een heuvel bereikte, Nur en Patendibor kwamen aan een dal, totdat 
Nur dlàfo maná, fare Nur n-jāl sus na ga nfaròma Patendibor. Fare nduk tjitjoal okòtjé, fare dtagtaga hnjēri tja fawé.

Mnu pa nagá hnjēri nlàfo mali pāt isa, ta ngahnjo „Pāt daga lego” ${ }^{1}$ ) Pāt tja smo na npangang fare nfasisio. Fare mapíng balo tja nu laitane : „Pāt daga lego mpangang”, fare pāt tja npangang, fare mapíng balo tai ntjapil namúl Pāt daga lego smo na loló na. Fare ni uta ba-sá nteteam mali Pāt daga lego tja smo pero na. Mnu pa nagá Nur ire Patendibor dlàfo mali pāt tja. Fare Nur nololau: „Aje, aje! msapang!” Fare Nur nua Pāt daga lego tja: „E, Pāt daga lego, msia smom na, bo ameksung bená”. Mai pāt tja ntjia smo na pa.

Tina tò fare Nur ire Patendibor dtangis maná, denabé masiusewil. Mnu pa nagá dem hnjēri ni uta ba-sá mali Pāt daga lego tja smo na, fare d-jāl i. Fare uta ba-sá tja ndadi tatalē mān isa, tankuku dòram re wōl. Nur ire Patendibor dfānfān fare nduk laling pantò, fare Nur namal ${ }^{2}$ ) nu laitane : „Tjiba, tjiba, tjiba! jaitaul ga i, jaitaul; jaibo ga $i$, jaibo; hnjēktja Djou Bòki ${ }^{3}$ ), hmak tja kolano i; jaisia mtak na suna pa nagá, ndadi fola djawa isa mantaine fare sungai isa n-jeli pāp papapo na!"

Tina tò ntjia mtā na ntjuna pa nagá ndadi fola djawa isa tan-gagam re lōb lōb, fare sungai isa n-jeli pāp fola djawa tja papapo. Fare Nur ire Patendibor simalī fola djawa tja fare riri tatalē mān tja nkuku dòram re wōl puis fola djawa tja ni pupungani.

Wōl pusa laitane Patendibor ndor pusi mali Nur, i nu laitane: „Nur mpei nik pusi boipusi rār go re ulang!’ Fare Nur namal; mnu pa nagá ndadi pusi salaka isa re smo na salaka bená. Patendibor n-jāl pusi na ga nfān(ĕ) ga nfapuspusi. Nuwe malī nut go re ulang na tutua isa, fare Nur n-jāl fare npei ān. Ān na masa i fare Nur ire Patendibor dtjeli. Wōl pusa wōl pusa Patendibor ni gogaho tiná be.

Mali ngadje-ngadje tai dafetang, Nur wawai mapíng isa ta uhngo na mafia, laisawa wōl re nga ta mulaen ta bontjapang mali olat, gitjo na. Wōl pusa laitane Patendibor nfān(ĕ) ga nfapus-pusi fawé. Infān mnu pa kolano wawaio isa nlàfo mali Nur ire Patendibor riri fola djawa

1) piät daga lego. In de Mal. vertalirg is er van gemaakt batu berdaun dan bertangkai. Ik kan het niet verklaren.

2) namal, een icverspreuk gebruiken. De Heer Bot deєlde mij mede, dat het betekent: dingen te voorschijn roepen, die er niet waren. Bijv. de radja wil een schip en hij roept : Tjiba, tjiba, tjiba en het schip is er. Alleen vorstelijke personen zouden dit vermogen hebben!

3) Deze toverspreuk is moeilijk te vertaler. Het slot is : „Hnjēk tja Djou Bòki $i$, hmak tja kolano $i$ ", ,mijn moeder $z \mathrm{ij}$ is een prinses, mijn vader hij is een koning". 
zij niet meer konden en Nur riep: „Moeder, moeder, moeder! wacht op ons!"

Vervolgens hun moeder had een weinig medelijden met hen en perste (drukte) haar zog in een grote schelp. Toen zij het uitgedrukt had, ging zij weer verder. Toen Nur daar aankwam, nam Nur het zog en gaf Patendibor te drinken. Vervolgens kreeg zij een beetje kracht en volgden hun moeder weer. Niet lang daarna bereikte hun moeder een steen, wiens naam was Pāt daga lego.

De bek (opening) van die steen kon gapen en zich sluiten. En de weduwe zeide aldus: „Pāt daga lego gaap!” En de steen (rots) gaapte en deze weduwe begaf zich binnen in de bek van Pāt daga lego. Vervolgens een van haar hoofdharen bleef achter op de rand van de bek van Pāt daga lego.

Niet lang daarna bereikten Nur en Patendibor de steen. En Nur riep: „Moeder, moeder! kom naar buiten!” En Nur zeide tot Pāt daga lego : „O, Pāt daga lego, open uw bek, opdat wij ook naar binnen gaan”. Maar de steen opende zijn bek niet.

Daarom Nur en Patendibor huilden daar, totdat zij heen en weer schudden. Niet lang daarna zagen zij een hoofdhaar van hun moeder aan de bek van Pāt daga lego en zij namen die. Vervolgens die ene hoofdhaar werd een haan, die bij dag en nacht kraaide. Vervolgens gingen Nur en Patendibor al gaande en zij vonden geen weg. Toen gebruikte Nur een toverspreuk en sprak aldus: „Tjiba, tjiba, tjiba! .... Ik open mijn ogen het is nog niet bereikt (ik heb mijn ogen nog niet geopend), of er ontstaat hier een tempeltje (geestenhuisje) en er vloeit een beek onderdoor!"

Daarna opende zij haar ogen, het was nog niet bereikt, of er ontstond een geestenhuisje, dat glinsterde en vlamde en een beek vloeide onder het geestenhuisje door. Vervolgens Nur en Patendibor zij kwamen herwaarts naar het geestenhuisje en hun haan, die kraaide bij nacht en dag, was boven op de nok van het geestenhuisje.

Op zekeren dag Patendibor vroeg aldus aan Nur om een boog, zeggende aldus: „Nur, maak mijn boog, opdat ik boogschiete onze go (e.s. vis) en garnalen". Vervolgens Nur bezigde een toverspreuk. Spoedig was er maar een zilveren boog en ook een zilveren pijl. Patendibor nam de boog en ging er aldoor mee schieten. Terugkerende bracht hij werkelijk go en garnalen en Nur nam die en bereidde het eten. Toen het eten gaar was. Nur en Patendibor aten. Elke dag was dat nu ook het werk van Patendibor.

In het verhaal wordt verteld, dat Nur een meisje was, schoon van Verh. d1. X. 


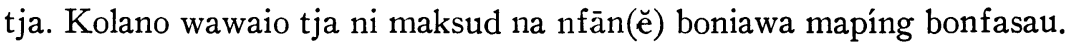
Waktu na nlàfo maná na, Nur ntotoláng potalíl ga ntamaga. Fare kolano tja nem Nur, fare nololau Nur nu laitane: „E, males tau, gabe

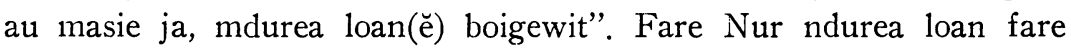
kolano tja $n$-gewit nais, fare nmauhnge ${ }^{1}$ ) Nur bonfasawa i. Fare Nur nailou.

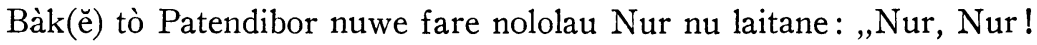

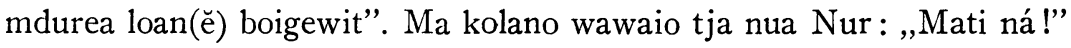
Nure bonmalawang(ě), namtjait kolano tja. Fare Patendibor ntangis nu laitane: „Nur, Nur, Nur! waja tja nlàfo nik pusal tja tò”. Nur nlònga laina fare ntangis nu laitane: „Patendibor, Patendibor! laling mantjá boijāl au! jamali smat(ě) kakamo loló!" Patendibor ntàngis fawé nu laitane: „Nur, Nur! waja tja nlàfo mali glaok tja tò”. Fare Nur ntangis na foloi fawé, nu laitane: Patendibor, Patendibor! laling

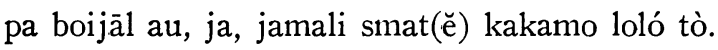

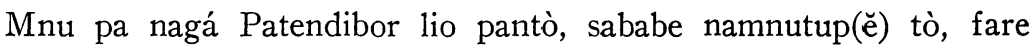
ntjung mali fofó isa fare namjaling lalī re malī.

Mnu pa nagá kolano tja n-jāl Nur fare nfasawa i, fare nuwea lalī ni limau tja.

Patendibor namjaling lalī re malī fare bonbaba i mali pnu isa ta ungo.

Mnu pa nagá fakiri ${ }^{2}$ ), isa ilalau olati ga nte tasi nut sop ara-sá isa. Nte tasi na mnu pa nagá fofó tja namjaling malī fare ntjung mali sop tja loló. Fakiri tja nem fofó tja ntjung mali sop tja, fare n-jāl fofó tja, ga ntopa $\mathrm{i}$.

Mnu pa nagá fofó tja imalī fare ntjung fawé. Tina tò fare fakiri n-jāl fofó tja, ga nut i lalei ni ebai i.

Sema tja fakiri tja ilalei bèti mai fofó tja nising i puis dodai na

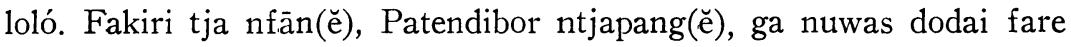
nlèsan mom, fare ntjina waja sino. Malingin tja fakiri tja nuwe lalau ebai, nheran na gaule, sababe pumúl ebai tja loló na beresi ndumi fare

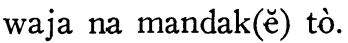

Sema tja fakiri tja ilalei bèti, nuwe malau nfalai na fawé. Fare fakiri tja nem ān na masa tò, fare $n$-jāle, ga ntjeli. Ntjeli mnu pa nagá nlònga dodai nakring! Fare inonau tatalē na n-gewit puis dodai na. Fare fakiri tja n-gigam nu laitane: us, us! bure, bure! mai dodai nakring be.

Mnu pa nagá fakiri tja ntjung namul dodai na gagau na, fare nem

1) manhnge (stam?). Volgens de Heer Bot betekent het, dat een jonge man persoonlijk een meisje vraagt zijn vrouw te willen worden.

2) fakir. In de Bulische verhalen een zeer bekende figuur. Mal. nenek kebajan. 
aangezicht, gelijk de zon en de maan, die beginnen op te gaan uit de zee, was haar huid. Op zekere dag Patendibor ging weer uit boogschieten. Hij was nog niet lang weg, een vorstenkind kwam bij de woning van Nur en Patendibor. Die prins zijn doel was om een vrouw te zoeken, opdat hij trouwde. Toen hij daar was angekomen, zat Nur buiten en pruimde sirih-pinang. Vervolgens zag de vorst Nur en hij riep Nur, zeggende aldus : „O gij maagd, indien ge medelijden met me hebt, laat dan de trap voor me neer, opdat ik opklimme". Vervolgens Nur liet de trap voor hem neer en de vorst klom naar boven en hij vroeg Nur zijn vrouw te willen worden, opdat hij haar trouwde. Vervolgens Nur stemde toe.

Toen het vloed was, keerde Patendibor terug en hij riep Nur zeggende aldus: "Nur, Nur! laat de trap naar beneden, opdat ik naar boven klimme”. Maar de vorstenzoon zeide tot Nur: „Doe het niet!” Nur was bevreesd de vorst tegen te staan. Vervolgens Patendibor huilde zeggende aldus: „Nur, Nur, Nur! het water is al gekomen tot mijn navel!” Nur hoorde het zo en weende, zeggende aldus: „Patendibor, Patendibor! langs welke weg zou ik je halen, ik ben in handen van mensen”. Patendibor huilde alweer zeggende aldus: „Nur, Nur! het water reikt al tot mijn hals!" Vervolgens Nur weende alweer zeggende aldus: „Patendibor, Patendibor! er is geen weg, dat ik je zou halen, ik, ik ben in handen van mensen!"

Niet lang daarna Patendibor gaf geen geluid meer, omdat hij was gezonken. Vervolgens hij ging in een citroen en dreef her- en derwaarts, totdat hij aanspoelde aan het einde van een dorp. Niet lang daarna een fakir ging naar de zee om zeewater te halen brengende een bamboekoker (geleding). Toen zij zeewater haalde, niet lang daarna de citroen dreef herwaarts en ging naar binnen in de koker. Vervolgens zij nam de citroen en wierp hem weg. Niet lang daarna de citroen kwam weer en ging in de bamboekoker. Daarom nam de fakir de citroen en bracht hem naar haar huis. 's Morgens ging de fakir naar haar tuin, maar de citroen legde zij op een bord. Toen de fakir weg was, kwam Patendibor uit de citroen en waste de borden en veegde het afval weg en maakte warm water.

Toen de fakir in de namiddag in huis terugkeerde, was zij verbaasd, omdat binnen in het huis alles schoon was en het water kookte. 's Morgens ging de fakir naar de tuin; zij keerde terug en zij vond het weer aldus. En de fakir zag het eten was al gaar en zij nam het en at. $\mathrm{Zij}$ had nog niet lang gegeten, toen $\mathrm{zij}$ de borden hoorde bekrabben (door kippen). $\mathrm{Zij}$ dacht, dat de kippen op de borden gekomen waren. 
fofó tja nomolol lalī re malī. Fare fakiri tja ilalī, ga nkautje fofó tja. Nkautje fofó tja fare Patendibor ntjapang. Tina tò fakiri tja ntjenga fare nu laitane: „O gabetá jaisisop na sisongit pa, jaiseli, mai mosi pa, sababe janik untung wawai isa tai ga!" Wawai tja wōl pusa uhngo nèsa, dòram uhngo nèsa.

Mulain tiná fare fakiri tja ndjagdjaga Patendibor na mafia. Gabe fakiri tja ilalei bèti nut Patendibor. Patendibor wawai isa tanmajeu npei bet fare gogaho rupa-rupa. Patendibor mān mamalawang pa. Mulaen tiná fakiri tja tantuba ntjusa re nmularat, tane ntjusa pantò, sababe wawai tja ndadi laisawa fakiri ntu tutuo i, fare laisawa ni uat $i$.

Laina ngadje-ngadje tai.

\section{Tjangkura-kura ire Bebe.}

Kolano pnu pusa, tede, tede bereá! Smat silú, isa ngahnjo Tjangkurakura, isa ngahnjo Bebe. Fare wōl pusa smat silú tasiá dfān diawa tatanaman. Fare duwe malau fare Tjangkura-kura na ntiwa polei māngmāng na, taga Bebe na ntiwa polau olati. Fere mumat tja malei n-jālo fare nmarapo; Tjangkura-kura na mumat tja neta pa.

Fare wōl pusa, fare Tjangkura-kura ire Bebe dfān dningo bèt. Fare silalī na Tjangkura-kura na ela na kokopē pantò, Bebe na mumat tja n-jālo, ga enpá. Fare wōl pusa wōl pusa tja laina tò, dfonla pa, denabé Tjangkura-kura na tela tja pio, denabé nmara pusa.

Fare wōl pusa Tjangkura-kura ire Bebe dfān fawé dningo rari bèt na. Fare lalei fare Tjangkura-kura ninga nais, nagá tela tja nmara. Fare nololau Bebe, fare Bebe inais fare n-gewit tela tja, fare nān( $\breve{\mathrm{e}})$ ni pio tja. Fare Tjangkura-kura nu laitane: „Bebe, motje ja o!” Fare Bebe nu laitane: „Ga okòtjé be!” Fare Tjangkura-kura nu laitane: „Gabe laina, motje nak gitjo na!” Fare Bebe nu laitane: „Mna be gitjo na!" Fare Tjangkura-kura nfān ndjaga ditja isa nmara. Fare mnu pa na, Bebe nfān malī, fare nu laitane: „Tjangkura-kura, gampesá mantae?” Fare Tjangkura-kura nu laitane: „Ga idjaga Djou tja ni lukam tai!” Fare Bebe nu laitane: „Tofnga be jaitofang fapusa?” Fare Tjangkura-kura nu laitane: „Ga osetane Djou tja ntolé!” Fare Tjang-

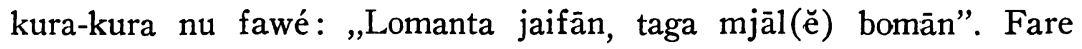


Vervolgens schreeuwde de fakir zeggende aldus: „Us, us! bure, bure!” Maar de borden bleven geluid geven. Daarop ging de fakir de bergplaats van de borden binnen en zij zag de citroen her- en derwaarts rollen. Daarna greep de fakir de citroen vast. Toen zij de citroen vastgegrepen had, kwam Patendibor er uit. Daardoor was de fakir verheugd en sprak aldus: „O gabetá (?), ik baadde en ben niet nat; ik at en ben niet verzadigd, want mijn geluk is dit kind. Dit kind heeft iedere dag en nacht een ander voorkomen!" Van toen af verzorgde de fakir Patendibor zo goed mogelijk. Indien de fakir naar de tuin ging, nam zij Patendibor mee. Patendibor was een zeer ijverig kind om tuinwerk te verrichten en allerlei werk.

Patendibor was iemand, die geen tegenstand bood (gemakkelijk van aard was). Van toen aan had de fakir, die vroeger veel moeite en zorgen had, geen moeite meer, want dit kind (deze jongen) werd alsof het een eigen kind van de fakir was alsof zij zijn grootmoeder was!

$Z_{0}$ is het verhaal.

\section{De landschildpad en de eend.}

De koning van zekere plaats, men eerbiedige hem maar! Er waren twee mensen, een zijn naam was Landschildpad, een zijn naam was Eend. Op zekere dag gingen die twee mensen plantsel zoeken. Toen zij naar de zeezijde teruggekeerd waren, plantte de Landschildpad het zijne aan de landzijde op het droge, daarna plantte de Eend het zijne aan de zeezijde aan zee. Vervolgens kwamen de golven (de branding) naar de landzijde en haalde er van (de aarde) en het viel om. Dat van de landschildpad raakten de golven niet.

Op zekere dag gingen de landschildpad en de eend de tuin bekijken. Toen ze daar waren de bananen van de landschildpad waren al niet laag meer, die van de eend waren door de branding meegenomen, daarom waren ze er niet. En iedere dag deden zij aldus, ze hielden er niet mee op, totdat de bananen van de landschildpad vruchten droegen en er één rijp was.

En op zekere dag gingen de landschildpad en de eend weer hun tuin bezien. Toen zij aan de landzijde waren, keek de landschildpad naar boven, zijn bananen waren toch al rijp. En hij riep de eend en de eend zij ging naar boven, zij beklom de banaan en at de vruchten er van. Toen zeide de landschildpad aldus: „Geef mij er ook van”. En de eend zeide: „Er zijn er maar weinig ( $\mathrm{er}$ is maar een beetje)!” Toen zeide de landschildpad weer: „Als het zo is, geef me dan maar de 
Tjangkura-kura nfān, fare Bebe n-jāl ditja pusa fare nān i fare nfànas i! Fare nfān ga nololau Tjangkura-kura. Fare Bebe nu laitane: „Tjangkura-kura, pesa ga ditja amua lukam i?"

Fare Bebe nu fawé: „Tjangkura-kura, gampesá?” Fare Tjangkurakura nu laitane: „Ga idjaga Djou tja na sobutu pusa!” Fare Bebe nu laitane: „Tofnga tofang fakòtjé?” Fare Tjangkura-kura nu laitane: „Osetane Djou tja nēm okòtjé galeli, fare ntolē!” Fare Bebe nu fawé: „Asal be wakòtjé!” Fare Tjangkura-kura nu laitane: „Lomanta ifān, taga mjāl bo māni!' Fare Tjangkura-kura nfān. Fare Bebe n-jāl okotjé, ga nān; fare nān, fare fatna tjitjaja tja pau na, fare nfān. Fare nololau Tjangkura-kura, fare Tjangkura-kura ntjanglo, fare Bebe nfān malī nagá Tjangkura-kura ndjaga pijai isa. Fare Bebe nu laitane: „Tjangkura-kura, gampesá ?” Fare Tjangkura-kura nu laitane: „Ga idjaga Djou tja ni pelang tai!” Fare Bebe nu fawé: „Tjangkura-kura, jaisaplo i wakòtjé o!” Fare Tjangkura-kura nu laitane: „Osetane Djou nem okòtjé marasawa bontolé!” Fare Bebe nu laitane: „Asal be wakòtjé ja!” Fare Tjangkura-kura nu laitane: „Lomantá ifān, taga msaplo i!" Fare Tjangkura-kura nfān, fare Bebe ntjaplo pelang tja, fare npei kabata isa: „La, la, la, ta, ra, la, la, la, la!” Fare pijai tja golo re boboko na npaling ndumi, fare nān Bebe, fare nmat. 
schillen!” En de eend zeide aldus : „De schillen er van zijn ook lekker!”

Toen aldus ging de landschildpad op een rijpe Spaanse pepervrucht passen. Niet lang daarna kwam de eend hierheen en sprak aldus: „Landschildpad, wat doet gij hier?” En de landschildpad sprak aldus: „Wel ik pas hier op de lansat van de heer vorst!" Toen zeide de eend aldus: „Laat me er slechts eentje van proeven?” En de landschildpad sprak aldus : „De vorst zal er zeker boos over zijn!” En de landschildpad zeide weer: „Wacht, dat ik weggegaan ben, dan pas neemt ge om op te eten!” En de landschildpad ging weg en de eend nam een Spaanse pepervrucht en at die op en ze brandde zich. Toen ging zij maar de landschildpad roepen. En de eend sprak aldus : „Landschildpad, waarom zeidet ge, dat Spaanse peper lansat was?" Daarop zeide de eend alweer: „Landschildpad, wat doet ge?” En de landschildpad sprak aldus : „Wel ik pas op de hoop eten van de vorst!” Toen zeide de eend aldus : „Laat me er een beetje van proeven?” En de landschildpad sprak aldus: „De vorst ziet zeker, dat het een beetje afgebrokkeld is en dan is hij boos!" En de eend zeide weer: „Al is het maar een klein beetje!” Toen sprak de landschildpad aldus: „Wacht dat ik weggegaan ben, dan pas neemt ge en eet!' Vervolgens de landschildpad ging weg en de eend nam een beetje en at het; toen zij het at rook zij er dreklucht aan, daarop ging zij weg.

Vervolgens riep zij de landschildpad en de landschildpad antwoordde en de eend kwam herwaarts en de landschildpad paste juist op een krokodil. En de eend sprak aldus: „Landschildpad, wat doet ge?” En de landschildpad zeide aldus: „Wel ik pas hier op de prauw van de vorst!” Toen zeide de eend weer: „Landschildpad, laat me er eventjes inzitten?” En de landschildpad zeide aldus: „De vorst ziet zeker, dat het een beetje gescheurd is en zal boos zijn!" Toen sprak de eend aldus : „Als ik maar eventjes mag!” Toen zeide de landschildpad aldus : „Wacht, dat ik weggegaan ben, dan pas gaat ge er in zitten!" En de landschildpad ging weg en de eend ging in de prauw zitten en zij zong een roeiliedje: „La, la, la, ta, ra, la, la, la, la!” En de krokodil richtte zijn staart en kop (allemaal) samen op, en hij at de eend op en zij was dood. 


\section{Bòki Talai gulo ${ }^{1}$ ).}

Kolano pnu pusa, tede, tede bereá.

Mali pnu isa, Kolano isa ire ni ngolotá, nturi mān isa ; fare wōl pusa nturi tja nua hmā re hnjē si: „Taun tatboboi taie, jaboifān boiburu banga, ikupa mani”.

Taun tja nlàfoi fare n-jāl ni pusi pusa fare nfān lalei fare ntjapial waja isa fare n-gewit lolas, nduri nap lolo isa ; lolas sifít, lolo sifít, fare nlàfo mali lajan isa, fare ulan( $\breve{\mathrm{e}})$, farea ilalī ga ntotoláng mali lajan tja papāpo. Fare bòki tja nèmi, fare bòki tja ntamaga, fare nitif nap wawai mān tja kakamo na.

Fare wawai mān tja n-garajan, fare inmauting taie: „Botu māni na dpeke, gaba pau paliu re fawat, botu paliu re fawat, gaba smat pa”. Fare bòki tja nlònga; fare nua mān tja: „Mgewit nais”. Fare mān tja nu laitane: „Ga tane wawaléng(ě) ga ikafèna pa”. Fare bòki tja npo paku sifít, fare npakua si lalī lajan tja. Fare n-gewit nais fare nean bòki tja denabé nfasawa $i$.

Fare wōl pusa fare mān tja nua bòki tja: „Taun tatboboi tai ituwe

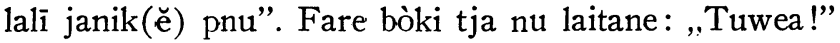

Fare riri taun tja nlàfo $\mathrm{i}$ fare dfān, farea dlàfo waja isa, dlàfo mali pnu tja lalei. Fare mān tja nua bòki tja: „Mteteam mantá tò, mati mlàfo lalau na, lomanta au malei, bokjāl au famafia".

Fare bòki tja n-gewit mali aisá ntub natá waja tja fare ntotoláng. Fare mnu pa nagá kòro isa imalei nte waja. Fare ninga nais nagá, nem bòki tja ntotoláng. Fare kòro tja n-gewit nais, fare ntopa bòki tja nap waja tja loló. Fare bòki tja ntjung ai màglo isa, fare namjaling lalau olati. Fare namjaling lalau nagá, neta fakiri isa. Fare fakiri tja n-jāl ai màglo tja fare nuti lalau ebaii, fare ntigea ilali diring tja, fare nbeki pa, denabé bòki tja ntu tja nlàfa.

Fare wōl pusa fakiri tja ilalei bèti, nuwe malau na ntotoláng(ĕ) ga ntjeli betò. Fare wōl pusa fakiri n-gogàni mali sasun isa, fare bòki ntu tja nlàfa. Fare bòki tja ntjapang bontjisop ntu tja, fare bonpei ān. Fare bòki tja nua ni kòro isa nfān boningo smat. Fare kòro tja nu laitane: „Ga smat pa”; fare bòki tja nu laitane: „Gabe amdel pa”, fare kòro tja nu laitane: „Smat papisan”. Fare bòki tja ntjapang natá ntjisop ntu tja. Fare fakiri tja ntjapang natá, fare nu laitane: „Djou bòki ga tane, au mantjawa malī?” Fare bòki tja nu laitane: „Ga wōl pusa tanfān ga nte

1) Bòki is de titel van een prinses te Ternate.

talai, e.s. boom: vari: zijn bladeren maakt men matten.

gulo, de palmiet van die boom. 


\section{Prinses Talai gulo.}

De koning van zekere plaats, men eerbiedige hem maar!

In zekere plaats was een koning, hij en zijn vrouw, hun kind één zoon. Op zekere dag hun zoon, hij zeide tot zijn ouders: het komende jaar, ik wil gaan, ik wil gaan rondzwerven in het bos; ik ga met een blaasroer vogels schieten.

Het jaar was aangebroken, vervolgens hij nam zijn boog een en hij ging landwaarts en hij trok over een rivier en hij besteeg een berg en daalde af in een dal; zeven bergen, zeven dalen en hij kwam bij een lajan-boom en het regende; vervolgens hij ging daarheen en zat onder de lajan-boom. En de kat-prinses zij zag hem en de kat-prinses, zij pruimde sirih en zij spuwde naar beneden op de handen van de jonge man. En de jonge man verbaasde zich en hij sprak: dit, wij zouden zeggen : de vogels poepen, maar het is de reuk van pinang en sirih; wij zouden zeggen: pinang en sirih, maar er is geen mens! Vervolgens de kat-prinses zij hoorde het en zij zeide tot de jonge man: „Klim naar boven!” En de man hij zeide aldus: „Maar het is zo glad, ik kan het niet". En de kat-prinses zij gaf hem zeven spijkers en hij spijkerde die daar in de lajan-boom en hij klom naar boven en hij verzorgde de katprinses, totdat hij met haar trouwde.

Op zekere dag de man hij zeide tot de kat-prinses : „Het komende jaar wij keren daarheen naar mijn plaats" (dorp). En de kat-prinses zij zeide aldus: „Wij keren terug”. Toen het komende jaar er was, zij gingen en zij kwamen bij een rivier, zij waren landwaarts bij een dorp. En de man hij zeide tot de kat-prinses : „Blijf jij hier, wil niet naar het dorp komen, wacht jij en blijf landwaarts, wij zullen je behoorlijk halen!"

Vervolgens de kat-prinses zij beklom een boom, die daar aan de rivier stond en zij zat. Niet lang daarna een slavin kwam daar heen, om water te halen en zij keek naar boven en zij zag de kat-prinses en de slavin zij klom naar boven en gooide de kat-prinses naar beneden in het water. En de kat-prinses zij ging in een grote boomtak en zij dreef zeewaarts naar zee. Toen zij zeewaarts dreef, zij trof een fakiri (oude vrouw) aan en die oude vrouw zij nam die grote boomtak en bracht die zeewaarts naar haar huis en gooide hem daar tegen de wand en bekommerde zich niet om hem, totdat het kind van de kat-prinses geboren was.

Vervolgens op zekere dag ging de oude vrouw naar de tuin, zij keerde zeewaarts terug, zij ging zitten en zij at ook maar. Op een dag de oude vrouw zij verborg zich in een hoek en het kind van de kat-prinses dat was geboren. En de kat-prinses zij ging naar buiten willende zij baden 
tasi nagá ai maglo tanamn-jaling malī gabe ja tantopa ja na ahai? Fare fakiri tja nu laitane: ,Jai tota au ja, ikising au famafia. Jai tōpa ta au tane. Jai tō bereá, ikising au famafia". Fare nua bòki tja ire ntu tja dgewit mali loan tja, bo sinais balata i.

Fare Djou mangòfa nfasawa riri kòro tante waja tja. Fare wōl pusa, fare kòro tja ni uattá nowil, fare mān tja nua kòro tja : „Mfān( ĕ) bompei lilewing”. Fare kòro tja ire ntu isa bená. Fare kòro tja nfān npei lilewing na, ntu tja nfateam i. Fare denabé bòki ntu tja mamàgal, fare nfān lalau kòro tja ire ntu tja, fare nfafable maná. Fare smat du laitane: „Taie laisawa antumi na”; fare pona kòro tja ni uattá nu laitane: „Tutuo jantuki, nane taie jantuki pa".

Fare ta tina tò mān tja npun kòro tja ire ntu tja fare nmat. Fare ilalei ga nfasawa bòki tja, fare inean bòki tja ire ntu tja, denabé taun pes musum. Tòtò tò. 
het kind, vervolgens zij maakte eten. En de kat-prinses zeide tot haar slavin, dat zij zou gaan zien of er mensen waren. En de slavin zeide aldus : „Er zijn geen mensen”. En de kat-prinses zeide aldus : „Indien gij het niet gelooft!” En de slavin zeide aldus : „Geen enkel mens”. En de kat-prinses zij ging naar buiten en zij baadde het kind.

Toen kwam de oude vrouw naar buiten en zeide aldus: Mevrouw Kat-prinses maar hier, gij komt van waar hierheen? En de kat-prinses zeide aldus : wel op zekere dag ging zij zeewater scheppen (halen); toen dreef er een grote boomtak hierheen; als die zij mij weg wierp mij, wat zou dat? En de oude vrouw zeide: ik zou u gehakt hebben, ik zou $\mathrm{u}$ heel goed opgeborgen hebben! Ik wist niet, dat $\mathrm{u}$ hier waart. Als ik $\mathrm{u}$ maar gekend had, dan had ik u een goed plaatsje gegeven. En zij zeide tot de kat-prinses en haar kind, zij klommen de trap op, opdat zij plaats namen op het rek boven de stookplaats.

Vervolgens Djou mangòfa hij trouwde met haar slavin, die water schepte (haalde) ${ }^{1}$ ). En op zekere dag de echtgenoot van de slavin hij had koorts (was ziek). En de man zeide tot de slavin: „Ga uit om groente te maken". En de slavin, zij had ook een kind. En de slavin zij ging en maakte groente. Haar kind liet zij achter.

Vervolgens het kind van de kat-prinses was groot en hij ging zeewaarts naar het kind van de slavin en hij speelde daar. En de mensen zeiden aldus: dit is als uw kind! En de man van de slavin zeide aldus: zeker, het is mijn kind, maar dat is mijn kind niet! En daarom de man hij doodde de slavin haar en haar kind en zij was dood.

Vervolgens hij ging landwaarts en trouwde de kat-prinses en hij verzorgde de kat-prinses en haar kind aldoor zonder ophouden.

Het is uit.

1) Hier maakt het verhaal een wending en gaat het terug naar de slavin, die de kat-prinses in het water wierp; als de man zijn eigen kind in dat van de kat-prinses herkent, doodt hij de slavin met wie hij getrouwd was. 


\section{Ngangatá.}

Kolano pnu pusa, tede, tede bereá. Ngangatá. Mān isa ire ni ngolotá fare nturi mapíng isa. Wōl pusa fare mapíng tja ire ni uattá dpei loga bodfagaso.

Fare malinging tja mān tja ire ni ngolotá dfān dfagaso. Nturi tja dfateam i mali obob isa.

Fare nganga isa imalì fare npei lio mali wawai tja làpo na. Fare wawai tja nu laitane: „Ajakē ire mamaké dfagaso nak go re ulang, kòtje-kòtje au pa!" Fare nganga tja nlònga i fare imalī, fare nutan wawai tja : „Nam pupuráng pa?” „Entane”. „Nam waja pa ?” „Entane”. „Nam ulan pa ?” „Entane”. „Nam pira pa ?” „Entane”. „Nam leslesan pa ?” „Entane”. „Nam pira gagau pa ?” „Entane”. „Nim ai pa ?” „Entane”. „Nim jap pa ?” „Entane”.

Fare nutan i nfonla, fare nganga tja n-jāl jap fare nep waja bonfoi ān wawai tja fare nmasa. Fare nganga tja nfading-dingi wawai ta nfoi-ān i tja, nu laitane: „Ding, ding, popolulu, poporá, nduk tai kāne naki ja!' Fare nfading-dingi nfonla fare nān wawai tja.

Fare nganga inais wawai tja gagau na. Fare wawai tja hmā re hnjēsi simali. Fare dtaping go re ulang na, fare dolol i. Fare nganga tja nu laitane: „Nak ān na inais”. Fare sema tja nganga tja nu laitane: „Ajakē, boipeke!" Fare nganga tja nafnet ai aisa. Fare mapíng tja nu laitane: „Au maná tò" Ja na tapo tabe! Fare nganga tja nopa; fare npei, mapíng tja nu laitane: „Nganga, ntuk mantjá?” „Ikān i ga. Ni long na igaile mali gigiap popó !" Fare wawai tja hmā re hnjēsi dtagtaga nganga tja,

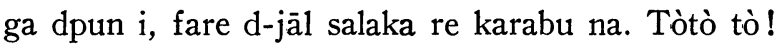




\section{De Uil.}

Een koning van zekere plaats, men eerbiedige hem maar! De Uil. Er was een man met zijn vrouw en hun ene dochtertje. Op zekere dag maakten de vrouw en haar man fakkels, willende vis gaan zoeken bij fakkellicht. Toen het avond was, gingen de man en zijn vrouw vis zoeken. Hun kind lieten zij achter in een mand.

Toen kwam er een uil hierheen en hij maakte geluid aan de zijde van het kind. Het kind zeide: ,Moeder en vader zijn aan het vis en garnalen zoeken voor mij, (maar) ik geef er niets van aan jou!' De uil dat horende, kwam herwaarts en vroeg het kind: „Hebt ge geen wan?” „Hier is hij!” „Hebt ge geen water?” „Hier is het!” „Hebt ge geen pan?” „Hier is zij!” „Hebt ge geen gebakken sagoe?” „Hier is ze!” „Hebt ge geen veger (bezem)?” „Hier is hij” „Hebt ge geen sagoevorm ?” ,Hier is hij !” „Hebt ge geen hout ?” „Hier is het!” „Hebt ge geen vuur?" "Hier is het!" Toen hield hij op met vragen en de uil nam vuur en goot water uit (in een pan) willende eten koken van het kind en het was gaar. Vervolgens zong de uil een kinderliedje voor het kind, dat hij kookte; hij zeide aldus: „Ding, ding, rond en dik, het wordt tot eten voor me gemaakt!" ') Nadat hij ophield met zingen, at hij het kind op. Daarop ging de uil in de plaats van het kind zitten.

Toen keerden de ouders van het kind terug en roosterden de vis en de garnalen rolden ze op. En de uil zeide aldus: „(Geeft) mijn eten naar boven!”'s Morgens zeide de uil aldus: „Moeder, ik wil gaan poepen!" Daarna liep de uil over een boomstam. De vrouw zeide : „Blijf gij daar!” „Ik ga naar de punt” (het eind). Vervolgens vloog de uil weg. Terwijl hij dit deed, zeide de vrouw: „Uil, waar is mijn kind?” „Ik at het op, ja! Zijn beenderen begroef ik onder de as!" Toen achtervolgden de ouders van het kind de uil; zij doodden hem en namen de arm- en beenringen en de oorringen. Het is gedaan.

1) Deze zin is me niet duidelijk. 


\section{Djou Lahatala ndadikan dunia taie ${ }^{1}$ ).}

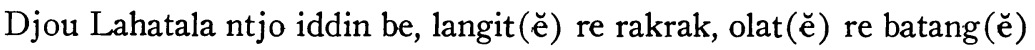
ndadi. Mulain takapó Djou Lahatala ndadikan dunia (alam) tamlàngo re mamàglo taie, mai uhngo laisawa tane paubé. Nbakbàka waja fare

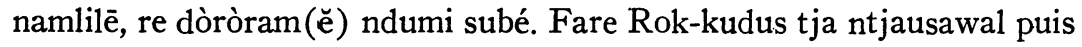
dunia taie. Sababe alam tamlàngo re mamàglo taie ndòròram $(\breve{e})$ re

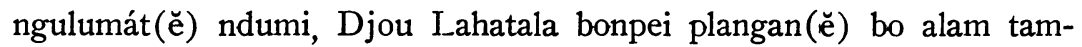
làngo re mamàglo taie naplàngan wakòtjé.

Fare Djou Lahatala ntjo iddin: „E plàngan!” Fare tatina tó alam taie naplàngan ndumi, mai plàngan famafia laisawa taine paubé, nuto

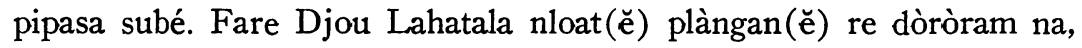
tanaplàngan tja nfangahnjo sema, tadòròram tja ngahnjo dòram. Denabé ndadii sema re dòram. Okotjesi talālo taine Djou Lahatala ndadikan mali wōl takapó famafia tja.

Sema tja ta wōl pilú na Djou Lahatala ntjo iddin fawé: „E, welisá

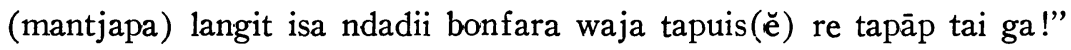
Fare tatina tò langit ndadi, fare waja ta mali dunia taie, pao ndawil nais langiti ga ndadi met(̌) re fam.

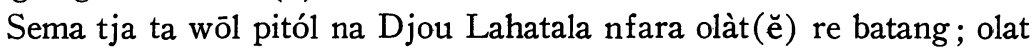

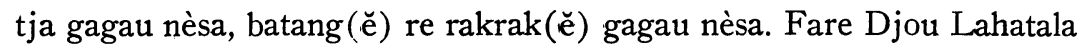
nfadadi ai lālo tangahnjo re pio re lilewing re wati re takiwi talālo ta mali dunia taie.

Sema tja ta wōl pifát na Djou Lahatala ntjo iddin fawé : „E, welisá (mentjapa ga) paisa tanfaplàngan na waisa (fadiran-tjá) ddadi si bodfaplàngan dunia taie ga. Fare ta tina tò wōl(ě) re nga re sagala aitotaf talālo na nadadii puis langití; wōl tja lomanta sema taga nfaplàngan; nga re aitotaf talālo na lomanta dòram taga npo plàngan nap dunia taie. Mali wōl takapó famafia tja denabé wōl pifát taie Djou Lahatala ndadikan dunia taie nkurang paisa pa pisan, nane be dangkis talālo ta mali duniai ta laisawa itetem taine enpaubé.

Gabe re laina na sema tja ta wōl pilim na Djou Lahatala ndadikan dangkis talālo tadopopa(ĕ) re tapāp olat loló na. Fare Djou Lahatala

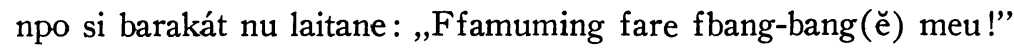

Fare sema tja ta wōl piwònam na takapó famafia Djou Lahatala ndadikan aiwani talālo tapāp rakrak loló re ta polei ailoló re ta fitjòri

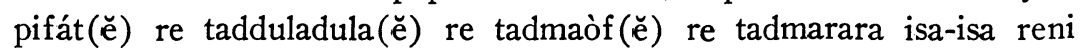

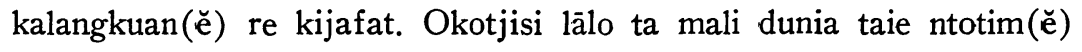

1) Het Bijbelsch verhaal van de Schepping door een Buliër naverteld. 


\section{De Here God schiep hemel en aarde.}

De Here God gaf slechts een bevel, de hemel en aarde, de zee en het land het werd. Het eerste begin de Here God Hij schiep deze wereld, haar lengte en haar grootte, maar haar voorkomen was nog niet als nu; zij nog vol water en zij was leeg (eenzaam) en alles was nog duister.

En de Heilige Geest hij zweefde boven deze aarde (wereld), omdat deze aarde haar lengte en haar grootte geheel duister en pikdonker was, de Here God Hij wilde maken licht, opdat de lengte en de grootte van deze aarde zij een beetje verlicht zou zijn.

Vervolgens de Here God gaf bevel: „E, licht!” Daarop deze aarde was geheel licht, maar het licht was nog niet als nu. Het was nog schemerachtig. Vervolgens de Here God Hij scheidde het licht en de duisternis. Wat het licht was, Hij noemde ochtend (dag), wat duisternis was noemde $\mathrm{Hij}$ nacht, diensvolgens $\mathrm{Hij}$ schiep dag en nacht. Dit alles schiep de Here God op de allereerste dag.

Het was morgen, de tweede dag. De Here God gaf weer een bevel: „Laat er zijn een hemel (uitspansel) zullende scheiden water, dat boven en dat beneden is". Daarop het uitspansel was er en het water, dat in deze wereld was, een deel steeg op naar het uitspansel, vervolgens het werd wolken en nevel.

Het was morgen de derde dag. De Here God scheidde de zee en het land; de zee een andere plaats en de aarde een andere plaats. En de Here God schiep allerlei bomen, wier naam was met vruchten en groenten en gras in allerlei soorten, die in deze wereld zijn.

Het was morgen, de vierde dag. De Here God gaf weer een bevel: „Laat er een zijn, die verlicht een deel, om te verlichten deze aarde!" En daarop zon en maan en al de vele sterren, zij werden boven aan de hemel. De zon, eerst 's morgens geeft zij licht; de maan en de vele sterren eerst bij nacht; zij geven licht beneden op deze aarde.

Op de allereerste dag tot deze vierde dag, de Here God, Hij schiep deze wereld en er ontbrak niets, behalve allerlei dieren, die op de aarde zijn, gelijk wij die nu zien, waren er nog niet. Daar het zo was de vijfde dag de Here God, Hij schiep allerlei dieren, die vliegen en die beneden in de zee zijn. En de Here God, Hij gaf hun zegen, zeggende aldus: „Baart en vermenigvuldigt U!”

Vervolgens het was de zesde dag na de allereerste dag. De Here God, Hij schiep allerlei dieren, die beneden op de aarde en in het bos zijn en die vier poten hebben en die zij kruipen en die tam en die wild zijn en die ieder naar zijn aard waren. 


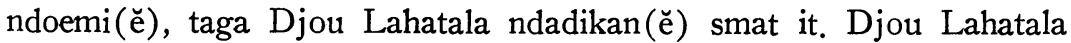

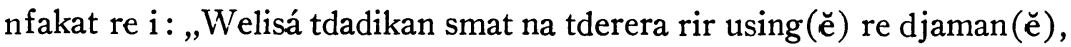
bo nparenta dangkis talālo ta mali alam tamlàngo re mamàglo taie ga!"

Fare Djou Lahatala n-jāl rakrak kakalá puk-puk isa fare ntuladai laisawa smat na famafia, taga nufa lamul guguo ni marapurus na nfasung nahas. Fare ta tina tó ndadi smati. Fare Djou Lahatala nfangahnjoi Adam. Fare Djou Lahatala nfatigi mali batang Eden mali

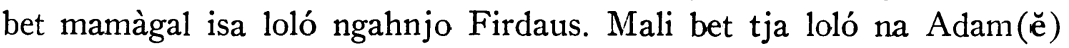
ntjusa paisa pa; okotjisi tanfaeda mali smat it tane enmaná ndumi.

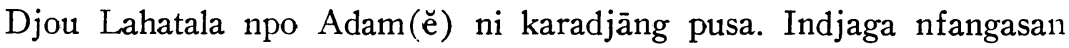
aiwani lālo ta enlalii na; ngasan tanpo na nderera isa-isa ni kalang-

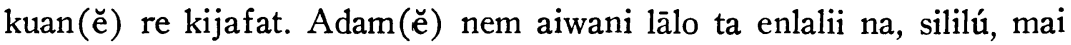

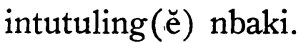

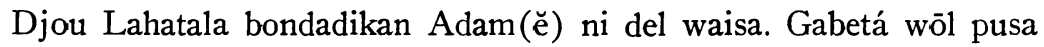

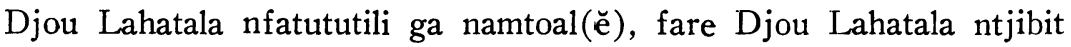

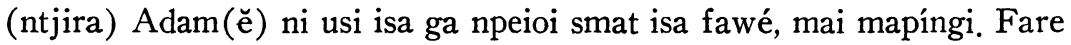
Djou Lahatala npoi lalī Adam i. Adam(ě) nemi na, fare nu laitand: „Wàngat tane, jawàngtok, fare long tane, jalongok!” Mapíng tja ngahnjo Hawa. Fare Djou Lahatala npo si barakat laitane: „Fbangbang(e) meu boffabakbak alam tamlàngo re mamàglo tai ga. Mesamúl na Djou Lahatala n-jel-jelo re ntel-telam okotjisi lālo tandadikan na mafia tu. Wōl piwònam loló Djou Lahatala ndadikan langit(e) re rak-

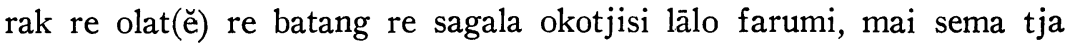
ta wōl pifit na Djou Lahatala nfonla npei paisa pantò, fare nfamamàgal re npo barakat wōl tja, sababe mali wōl tja Djou Lahatala npo barakat mali okotjisi tandadikan(ě) tò na. Wōl tja ngahnjo wōl Ahar (Sabtu). 
Alles, wat in de wereld was gereed, geheel voldoende. Toen pas schiep de Here God ons mensen. De Here God overlegde met Hem (zich zelf): „Laten wij (Laat ons) mensen maken, zij volgen ons voorkomen en onze houding, opdat hij maar regeert allerlei dieren, die op de aarde zijn lengte en grootte zijn".

Vervolgens de Here God, nam een klomp rode aarde en $\mathrm{Hij}$ vormde die gelijk de mens en blies in zijn neusgaten naar binnen en deed de adem naar binnen gaan. Daardoor toen pas hij werd mens. En de Here God Hij noemde hem Adam. En de Here God plaatste hem in het land Eden, in een grote tuin, zijn naam was Firdaus. In die tuin had hij geen enkele zorg. Alles, wat wij mensen behoeven (wat nut heeft) hier, het was er alles.

De Here God, Hij gaf Adam zijn werk een. Adam bewaakte de hof en hij gaf namen aan allerlei dieren, die daar waren, namen, die hij gaf volgens ieder zijn aard. Adam, hij zag allerlei dieren, die daar waren, ieder twee aan twee, maar hij zelf was geheel alleen. De Here God, Hij wilde Adam een gezel geven (maken). Diensvolgens zekere dag de Here God liet een zware, diepe slaap [over Adam komen] en de Here God trok een van Adams ribben uit en maakte daarvan weer een mens, maar het was een vrouw. En de Here God Hij gaf haar van zich af naar Adam. Toen Adam haar zag, Adam hij zeide: „Dit vlees, mijn vlees; deze beenderen, mijn been". De vrouw haar naam was Eva. Verder de Here God gaf hun zegen aldus: „Vermeerdert U, opdat gij maar volmaakt deze aarde (wereld) haar lengte en grootte". Daarna de Here God nam goed op en bezag al wat Hij geschapen had en het was zeer goed.

In zes dagen de Here God schiep hemel en aarde en de zee, en het land en alles te zamen, maar op de zevende dag $\mathrm{Hij}$ hield op en maakte niets meer en $\mathrm{Hij}$ maakte groot en gaf zegen die dag, want op die dag de Here God gaf zegen aan alles, wat $\mathrm{Hij}$ reeds geschapen had. Die dag zijn naam is Zondag (Sabtu, Sabbath). 


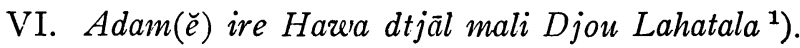

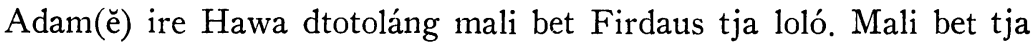
loló na bodtjusa ahai subé? Tatanaman lālo enmali bet tja ndumi. Ai lālo ta pio ja mna re mis-mis na enmaná ndumi. Adam(ĕ) re Hawa

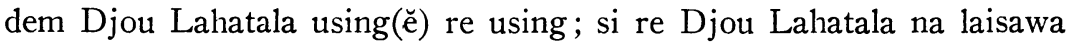
wawai ta si re hmā re hnjēri-si na, sababe Adam(ĕ) re Hawa Djou Lahatala ndadikan-tji na re riri dosa pusa papisan.

Adam(ě) re Hawa wōl de wōl na dtjenga re dkanjona be Djou Lahatala, fare dduk(ĕ) riri pisi re mafa pusa pa, mai si re Djou Lahatala dfaiteta paubé. Gabetá Djou Lahatala bontjoba si, bodfān-fanjo si mali ta mafia re maatangi, bo si re Djou Lahatala dfaiteta ga.

Takapó famafia Djou Lahatala ntjo bobita mali sili: „Ai ta lālo ta mali bet loló tane, meu fān(ĕ) pio na farumi, mai ai ta mali bet fapaluno

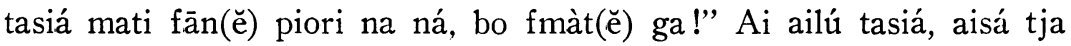
ngahnjo: Ai tub kakal; ai aisa tja ngahnjo: Ai tanfaso-njata mafia re majai. Djou Lahatala ntjoba si parakara pusa ta majana leo, sababe mali bet tja loló na ai ta re pio na, aisá lai ai-lú be pa, mai lāl tu. Adam(̌)

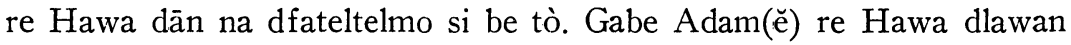
Djou Lahatala ni so-bobita na pa, osetane Djou Lahatala ntjoba si mali parakara pusa ta nèsa fawé, tanteb-teb fawé mali parakara tantuba na, denabé Adam(ĕ) re Hawa sinais mafia re maatang papó. Sababe Djou Lahatala ntjo-bobita si na, mnu pa fare sidlawan Djou Lahatala ni

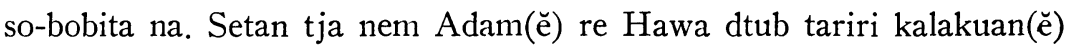

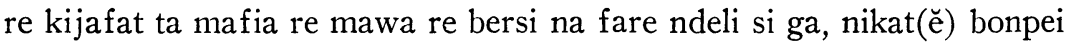

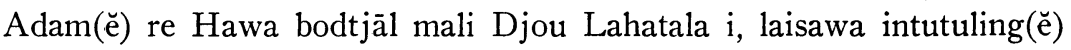
npei sāl mali Djou Lahatala i tò na.

Wōl pusa Hawa nfān-fān mali bet tja loló na, fare nalàso ai ailú tasiá. Fare Setan tja ntjung gu isa ga, nalàso ai tasiá be na. Bonlàfo Hawa Setan tja ilalī Adami pa, sababe ntō, osetane nafèna Adam pa, sababe mān na ulori na tjitjoal re mtu ga, mai mapíng na dmadle-dela leo, gabetá Setan tja ilali Hawa i na. Fare nutan Hawa : „Djou Lahatala ntjo-bobita meu laisawa? Wahle ntjo-bobita meu(ě) bo mati fān ai pio lalo ta mali bet loló tane na lahá ?” Fare Hawa nu laitane: „Pene, laina pa! Djou Lahatala ntjo-bobita am na laitane: „Nafale ai pio ta lalo mali bet taie loló, amekān farumi, nane be ai ailú tamali bet fapaluno tasine, mati kān(ě) piori na ná, bo kmat(ĕ) ga!" Fare gu (Setan) tja ntjanglo: „Meu fmat pa, mai Djou Lahatala nlarang(ě) meu ai ailú

1) Het Bijbels verhaal van de zondeval door een Buliër naverteld. 


\section{Adam en Eva zij zondigden tegen de Here God.}

Adam en Eva zij zaten (woonden) in de hof Firdaus (Eden). In die hof, welke moeite zouden zij nog hebben? Allerlei planten waren er in die hof alle. Allerlei bomen, die vruchten gaven, die lekker waren en zoet, zij waren daar alle. Adam en Eva zagen de Here God van aangezicht tot aangezicht. $\mathrm{Zij}$ en de Here God waren zoals kinderen met hun vader en moeder zijn, omdat de Here God Hij schiep hen met geen enkele zonde.

Adam en Eva zij waren dag aan dag slechts verheugd en blij in de Here God; zij waren niet ziek, zij hadden geen enkel somber voorgevoelen, doch zij waren nog niet gelijk aan de Here God. Daarom wilde de Here God hen beproeven, opdat zij langzamerhand zij kwamen tot volmaaktheid, opdat zij en de Here God daarin zij geleken op elkaar.

Het allereerste, wat de Here God hen beval was: Alle bomen, die in de hof zijn eet! gij eet hun vruchten alle, maar de bomen, die in het midden van de hof zijn, eet van die vruchten niet, opdat gij niet sterft". Die beide bomen, de ene zijn naam was ,boom van eeuwig leven” en de andere zijn naam was ,boom, die openbaart goed en kwaad”.

De Here beproefde hen in een zaak, die zeer licht was, want binnen in de hof waren vruchtbomen, niet één of twee, maar zeer vele. Adam en Eva zij aten ze, zij kozen ze slechts uit.

Indien Adam en Eva zich niet verzetten tegen de Here God zijn geboden, zeker de Here God beproefde hen weer in een andere zaak, die meer zwaar was dan de eerste zaak, totdat Adam en Eva zij bereikten de volmaaktheid.

Omdat de Here God, Hij gaf hun geboden, niet lang zij weerstonden de Here God Zijn geboden. De Satan hij zag Adam en Eva zij leefden hun gedrag en aard, die goed was en rein en hij was maar jaloers op hen, hij overlegde hij wilde maken Adam en Eva zouden zich misdragen tegen de Here God, gelijk hij zelf zich misdragen had tegen de Here God.

Op zekere dag Eva wandelde binnen in de hof en zij kwam tot die beide bomen. En de Satan hij ging maar in een slang, hij was dichtbij die beide bomen, willende dichtbij Eva komen. De Satan hij ging niet naar Adam, omdat hij zeker Adam niet aan kon, want mannen hun gemoed is sterk en hard, maar de vrouwen zij zijn lichtgelovig, daarom ging de Satan naar Eva.

En de Satan hij vroeg aan Eva: „Welk een bevel gaf de Here God aan ulieden? Misschien hij beval „Gijlieden zult niet eten allerlei boom- 


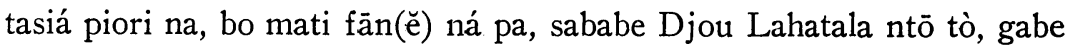
meufān, osetane mtā meu na laisawa dtjiai, fare meu re Djou Lahatala dfaiteta ga, ftō ta mafia re ta majai!"

Fare Hawa nlònga gu ni mau-mauting na na, fare natngalo ai tja

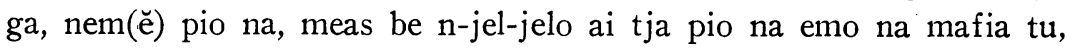
fare Hawa ni nafsu ai tja pio na. Pusa fawé inonau gu ni mau-mauting na molang, mai renta Djou Lahatala n-gogna si, fare Hawa nlangi kakamo na ga nkati (nafot) pusa ga nāni. Fare notje Adam bená ga Adame nān(̌̌) ntjuai.

\section{Guá mane $\left.{ }^{1}\right)$.}

Mali pnu isa ngahnjo Maban, mali pnu tja waja isa ngahnjo Osia. Polei waja tja uluo guá isa ngahnjo Guá mane, i re ni ngolotá fare nturi mapíng isa. Guá mane i re ni ngolotá bobokori sifít. Guá mane tai

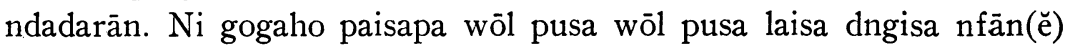
ga npun be smat fare nāntji. Gabe npun mapíng n-jāl( $\breve{e})$ riri salaka re riri pugau lebat fare karabu na. Denabé waktu tja na smat ta mali

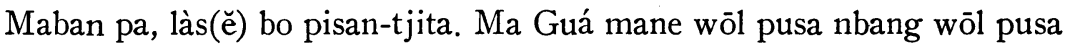
ndadi kajāng, sababe nlois smat na riri barang re riri arta.

Mnu pa na smat Maban dirantjá diāwa akal fare dfān Buli. Dlàfo mali Buli fare dfautan mali smat Buli dta tò lalau na. Fare smat Buli tadtjitjoal re dmakes na smat jafasá re silím dfān(ě) ga dpei et isa polei waja Osia ta ni uluo na. Fare smat jafasá re sitól dtotoláng fare dfura si pi ulú. Mai smat silú ta siriri kapita sitasá, dfapitno si mali et tja ni ai na; isa imali famule, isa imali sesela. Fare dtiltila ${ }^{2}$ ) lalau.

Dlàfo mali Guá mane ni ebai tja papapo na, fare mnu pa nagá Guá mane ntjaili1 ${ }^{3}$ ) nap fare bo nāntji. Ma waktu ntjailil nap, wōl tja npukal i fare ndòròram. Tina tò fare smat jafasá re sitól tasiá dpaling fare

1) Guá mane, een soort weerwolf, een boos gedrocht. In het Tobelosch meki (zie A. Hueting, Tobelosch Woordenboek, p. 243).

2) tiltila, vonrtdurend voortduwen met een stok, vocrtbomen van een vaartuig.

3) sailil, het neersch:eten v. e. roofvogel op een vis. 
vruchten, die in de hof zijn!” Vervolgens Eva zeide aldus: „Neen, aldus niet. De Here God gaf ons bevel aldus „Alle boomvruchten, die in deze hof zijn, zullen wij eten, alleen slechts de twee bomen, die in het midden van de hof zijn hier, wilt niet eten hun vruchten, opdat gijlieden niet zult sterven"”. En de slang (de Satan) hij antwoordde: „Gijlieden, gij sterft niet, maar de Here God verbood ulieden de vruchten van die beide bomen, omdat $\mathrm{Hij}$ weet al, indien gijlieden eet, zeker uw ogen alsof zij opengaan en gijlieden en de Here God maar gelijk zijn en gijlieden kent wat goed en wat kwaad is".

En Eva hoorde de woorden van de slang en zij keek maar naar boven naar de boom en zag de vrucht, komende te fixeren de vrucht van die boom, het zien ervan was zeer mooi. Vervolgens Eva haar begeerte die vrucht. En weer zij meende, de woorden van de slang waren waar, maar de Here God verborg het om die reden voor hen, vervolgens Eva zij stak haar hand uit en plukte een vrucht, vervolgens at zij die en zij gaf Adam ook en hij at met haar te zamen.

\section{Guá mane.}

In zekere plaats genaamd Maba, bij die plaats was een riviertje genaamd Osia. Landwaarts aan de bovenloop van dat riviertje bevond zich een gedrocht (weerwolf) genaamd Guá mane, hij en zijn vrouw en hun dochter.

Guá mane, hij en zijn vrouw hadden zeven hoofden. Deze Guá mane was zeer wreed. Zijn dagelijks werk was niet anders dan hij ging slechts mensen doden, vervolgens at hij die op. Indien hij vrouwen doodde, hij nam hun zilver, arm- en beenringen en hun haarspelden en hun oorversierselen. Daardoor waren er die te Maba bijna geen mensen meer, maar Guá mane werd van dag tot dag rijk, omdat hij de goederen en bezittingen van de mensen stal.

Niet lang (spoedig) zocht een deel van de Mabarezen een list en ging naar Buli. Te Buli aangekomen vroegen zij aan de Buliërs, zij klopten sagoe aan de zeezijde. Vervolgens de Buliërs, die sterk en moedig waren, 15 man sterk, zij gingen en maakten een vlot aan de bovenloop van de rivier Osia.

Vervolgens 13 man namen plaats (op dat vlot) en bedekten zich met pi- (een soort van plant) bladeren. Maar twee man, die hun aanvoerders waren, zij bonden zich vast aan het hout van het vlot; één aan het voorste deel (steven) en één aan de achtersteven. Vervolgens zij boomden (het vlot) naar de zeezijde. Aangekomen onder 't huis van de Guá 
djāl riri eta re pego na fare si re Guá mane dfaparang. Gabe Guá mane nfatjitjoal $\mathrm{i}$, riri et tja npupuang; gabe smat jafasā silím tasiá dfatjitjoaltji Guá mane ni go tja ntjoula i.

Mana fare smat Buli tasiá dfatjitjoal-tji, fare dtòta Guá mane boboko isa. Fare Guá mane nu: paisa paubé, otle siwònam subé! Laina laina denabé boboko sifít tasiá dtòta ndumi si fare Guá mane nmat. Ni ngolotá nem ni uattá nmàt(̌) tò fare ntjailil nap fare bo nān smat Buli tasiá. Mnu pa nagá smat Buli tasiá ntòta mapíng tja ni boboko isa. Fare mapíng tja nu laitane: paisa paubé otle siwònam subé! Laina laina be denabé boboko sifít tasiá smat Buli tasiá dtòta ndumi si. Fare smat Buli tasiá sinais riri ebai tja, fare dem long re smat na ni boboko nbak-bak mali siriri ebai tja loló na. Fare d-jāl Guá mane ntu mapíng tja ga nut i lalau Maban.

Sababe mapíng tja nmafia fare smat Maban isa $n$-jāl i ga nfasawa $i$. Dòram tja mapíng tja nfān(ĕ) ga namngai; sema lele salalu dem i nafnin mali smat na riri diring làpo na. Mnu pa na fare ni uattá ntalak i fare smat nèsa dfasawa i. Ntalak i nfonla i mān tja naguá. Salalu nfasawa mān isa, ostane mān tja naguá. Laina laina denabé smat ta mali Maban ampir daguá ndumi, sababe asal mali Guá mane ntu mapíng taie.

Nlàfo mantane be ngadje-ngadje tai. 
mane, spoedig de Guá mane schoot naar beneden (als een roofvogel) willende hen eten. Maar toen de Guá mane neerschoot, de zon verborg zich (achter een wolk) en het was donker. Daarna die 13 mannen stonden op en zij namen hun kapmessen en speren en zij en de Guá mane hakten op elkaar in. Indien Guá mane zich inspande, hun vlot... ${ }^{1}$ ); indien de 15 mannen zich inspanden (sterk maakten) de achterste delen van Guá mane kwamen in het water (weekten in het water). Vervolgens de Buliërs spanden zich in en zij hakten een hoofd van de Guá mane af. En de Guá mane zeide: „Het is niets, er zijn er nog zes over”. Het ging zo voort, totdat alle zeven hoofden alle waren afgehakt, vervolgens de Guá mane was dood.

Toen zijn vrouw zag, dat haar man al dood was, schoot zij naar beneden willende de Buliërs opeten. Niet lang daarna de Buliërs hieuwen een hoofd van de vrouw af. En de vrouw zeide aldus: „Het is nog niets, er zijn er nog zes over". Het ging zo voort, totdat de Buliërs alle zeven hoofden afgehouwen hadden.

Vervolgens die Buliërs zij gingen naar boven in hun (Guá mane) huis en zij zagen beenderen en mensenshoofden, hun huis van binnen was er vol van. Vervolgens namen zij de dochter van Guá mane en zij brachten haar naar de zeezijde, naar Maba. Omdat die vrouw mooi was, een Mabarees nam haar en trouwde met haar. 's Nachts ging die vrouw uit om te weerwolven. 's Morgens vroeg zij zagen haar gluren (bespieden) aan hun wanden (?). Niet lang daarna scheidde haar man van haar en een andere trouwde met haar. $\mathrm{Na}$ haar scheiden was de man weerwolf. Voortdurend trouwde zij met een man. Stellig (zeker) die man werd weerwolf. Aldus was het, totdat de mensen te Maba bijna allen weerwolf waren, omdat zij afkomstig waren van deze dochter van de Guá mane. Tot hiertoe slechts dit verhaal.

1) Hier staat een woord, dat in dit verband onduidelijk is. 


\section{Fajautá.}

Kolano pnu pusa, tede, tede bereá! Fajautá.

Ngolo ise ire ntu isa fare dpei bét, fare dtiwa fajau, fare top, fare tela, fare asbī, fare samaka, fare kastela rak-rak. Fare wōl pusa fare wawai tja nu laitane: „Aje kel boisibit fajau na wa isa!” Fare hnjē nu laitane: „Io!” Fare wawai tja ntjibit fajau na wa isa. Fare nut $i$ malau, fare ntjuf i nfonla i. Fare nkakati neto kasfit, fare ntjinanga fajau na. Fare ntjinanga nfonla $i$, nising mali gutji isa nfura teteta isa. Fare nfān(ĕ) ga nololau hnjē bodān fajau na. Fare hnjē nu laitane: „Amtuba betòl!” Fare wawai imalì nagá nlònga namul nagá : „Kring, kring!” Fare wawai tja nu laitane: „Bure! mana na bodpei tò nagá wōlwōlo tò ga!"

Fare wawai tja nu laitane: „Elele! iduk(ĕ) nik wawai ese!” Fare ngolo tja nu laitane: „Are! neka e! meantji famafia o!’ Wawai tasiá sifit: mān siwònam fare mapíng isa ndadi sifit. Fare tauwati tja ngahnjo Isa. Fare wawai siwònam du laitane: „Ngolo, ke! Nim eta leo pa?” Fare ngolo tja nu laitane: „Janik eta leo isa!" Fare wawai siwònam tasiá djāl eta leo tja ga, fare dtòki. Fare wawai sitól(ĕ) dpei

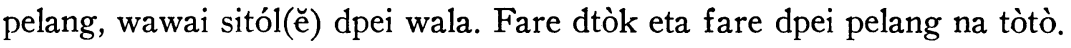

Fare wawai siwònam tasiá dfāne ga dfasagsagu: ian tja dwatang i. Fare silalai fare ngolo tja nu laitane: „Neka! mfān(ĕ) bometang si ga!”

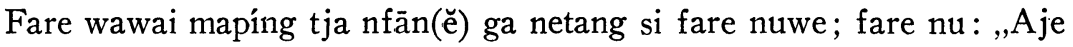
ke! dtotim ddumi". Fare wawai tasiá dut ian na lalei ga, dpei ga dān, fare dtjeli dfonla damtuli. Sema tja fawé fare dfasagsagu fawé. Fare dtjagu ian na ntjuli, fare duwe. Fare ngolo tja nu laitane: „Neka! mfān(ĕ) bo metang si ga !’ Fare wawai mapíng tja nfān(ĕ) ga netang si, fare nu laitane: „Ngolo ke! wawai tasiá dtotim ddumi!’ Fare wawai tasiá dut ian na lalai ga dpei ga dān. Fare sema tja hnjēri tja nu laitane: „Wawai tameu! ffān bereá, mati flà fo mali māne-hmā ire ni ngolotá ná !" Fare wawai tasiá ddela pa, re dtjali. Fare dlàfo lalau māne-hmā ire ni ngolotá riri ebai na fare wawai tasiá duwe. Fare dlàfo māne-hmā ni ngolotá npaling. Fare wawai tasine dlàfo malī, māne-hmā ni ngolotá tja nu laitane: „Fasagu nak ian taie!” Fare wawai tasiá nu laitane: „Imantjá ?” „Itaie!” „Imantjá ?” „Itaie!” Fare wawai ta ngahnjo Sifit tja ngogan i mali awat na papapo na. Fare māne-hmā ni ngolotá nelolau si. Fare ta ngahnjo Sifit tja inais māne-hmā ni ngolotá i. Fare mānehmā ni ngolotá npun wawai ta ngahnjo Sifit tja nmat, fare ngaile mali totaf tutu na. Fare wawai tasiá dtangis, lalei baba si lalau baba si.

Fare wawai tasiá duwe lalei ebai i. Fare ngolo tja nu laitane: „Neka! 


\section{De aardorucht (Mal. kaladi).}

Een koning in zekere plaats, men eerbiedige hem maar! De aardvrucht.

Er was een vrouw met haar ene dochtertje en zij maakten een tuin en zij plantten kladi en suikerriet en bananen en cassave en meloenen en bataten. En op zekere dag sprak het kind aldus: „Moeder, ik wil een stuk kladi uittrekken”. En de moeder zeide aldus: „Ja”. En het kind trok een stuk kladi uit en zij bracht (het) naar de zeezijde en toen zij gereed was met het te schillen, sneed zij het aan zeven stukken en zij bakte de kladi. Toen zij klaar was met ze te bakken, legde zij ze op een schotel en dekte ze toe met een zeefje en zij ging haar moeder roepen om de kladi te eten. En haar moeder zeide aldus: „Ga jij maar eerst". Toen het kind thuiskwam, hoorde het naar binnen maar: kring, kring! En het kind sprak aldus : „Brr! die vogels zij willen doen maar" (deze zin is verder niet te vertalen).

En het kind zeide aldus: „Verbazend, ik verkreeg enige kinderen!” En de vrouw sprak aldus: „Pas op, jongere zuster, verzorg ze goed, hoor!" Die kinderen er waren er zeven, zes jongens en een meisje, dat maakte zeven. En de oudste zijn naam was Een. En de zes kinderen zeiden aldus: „Grootmoedertje, hebt ge geen oud kapmes?” En de vrouw sprak aldus: „Ik heb een oud kapmes”. Toen namen die zes kinderen dat oude kapmes en beukten (smeedden) het. Vervolgens drie jongens maakten een vaartuig en drie jongens maakten touw. En het kapmes was gesmeed en het vaartuig gemaakt.

Toen gingen die zes jongens vissteken. De vis zij was er in grote hoeveelheden. Toen gingen zij naar de landzijde. En de vrouw sprak aldus: „Jongere zuster, ga jij ze tellen ja!" En het meisje ging en telde ze en kwam terug en zeide: „Moeder, ze zijn voltallig (zijn er allemaal)". En die jongens brachten de vis naar de landzijde en zij bereidden ze en aten ze. Toen zij gereed waren met eten, sliepen zij. Toen het weer ochtend was, gingen zij weer vis steken. En zij staken vis en er was een hoop, vervolgens keerden zij terug. En de vrouw zeide aldus: ,Jongere zuster, ga jij ze eens tellen!" En het meisje ging en telde ze en zeide aldus: „Grootmoedertje, die jongens zijn er allemaal”. En die jongens brachten de vis naar de landzijde en bereidden ze en aten ze. Toen het ochtend was sprak hun moeder aldus: „Gij kinderen als gij dan maar gaat, wilt dan niet komen tot de māne-hmā (een soort bosgeest met weerwolven aard) met zijn vrouw !' En de jongens geloofden niet en zij roeiden weg. Toen kwamen zij aan de zeezijde bij het 
mfān(ĕ) metang si ga!" Fare wawai mapíng tja nfān ga. Fare wawai tja ilalei ga nu laitane: „Ngolo ke! wawai tasiá siwònam be! Fare ngolo tja ntangis, fare wawai tja ga ntangis be.

Fare māne-hmā ni ngolotá ntjina waja sino. Fare nduplo wawai tanmat tja, naise faifít, nàpe faifít, wawai tja nfafulfultja $\mathrm{i}$; naise faifít, nàpe faifít, ni long na nfatibtibil ; naise faifít nàpe faifít, nosal, naise faifít, nàpe faifít nfān. Fare māne-hmā ni ngolotá n-jāl pake na ga nfapake wawai tja. Fare dfān(ě) ga silalei ngolo tja. Fare dololau fare ngolo tja nu laitane: „Ta nololau tai pota taie laisawa jantuk tja!" Fare wawai tja nu laitane: „Aje ke! mgali ja!” Fare wawai tja nololau fawé: ngolo tja ntjupat bawa tja. Fare mapíng ntjaf ngolo tja na sus ja totoláng, tamāni tja ntjàfe teno na rari sasagou na nmesngai.

Fare sema tja fare pia. Fare māne-hmā niāwa ni ngolotá ga nduk i pa. Fare nololau smat nu laitane: „Ta pàgi re ta beru fsapang!” Fare smat tadkowe dtjapang ddure fare fān(ĕ) ga diāwa māne-hmā ni ngolotá.

Fare sema tja smat pelang asa dfatitial fare dem mamajás isa fare duwe fare silalei māne-hmā i ga du laitane: „Are, māne-hmã namajás isa ta puis tja". Fare māne-hmā i re ni bala dfān(ě) ga dningo máne-hmā ni ngolotá, fare dlàfo mali māne-hmā ni ngolotá i na; fare dfapepea riri snapan na fare dtapngo nais ga dlàfo si pa, fare denabé smat na dmàte dumi, fare otle be māne-hmā fare denabé smat na dmàte dumi, fare otle be māne-hmā fare māne-hmā ni ngolotá nane ntapngo mānehmā fare nmat. Fare sileduwe fawé lalei riri pnu tja. Tòtò tò! 
huis van de māne-hmā en zijn vrouw en die jongens keerden terug. Toen zij herwaarts gekomen waren, stond de vrouw van de māne-hmā op (ontwaakte zij). Toen deze jongens herwaarts waren gekomen, de vrouw van de māne-hmā sprak aldus: „Steekt deze mijn vis!” En die jongens zeiden aldus: „Waar is hij ?” „Hij is hier!” „Waar is hij ?” „Hij is hier!" Vervolgens de jongen, wiens naam was Zeven, verborg zich onder het zitplankje (in het vaartuig). En de vrouw van de mānehmā riep hen. En wiens naam was Zeven ging naar boven naar de vrouw van de māne-hmā. En de vrouw van de māne-hmā doodde de jongen, wiens naam was Zeven en hij was dood en zij begroef hem onder de drup van het dak van het huis. Vervolgens die jongens schreiden aan de landzijde op het strand geworpen zij aan de zeezijde op het strand geworpen zij. (Deze zin is vrij duister). Vervolgens keerden de jongens terug naar de landzijde naar huis. En de vrouw zeide aldus : ,Jongere zuster, ga jij ze eens tellen!” En het meisje ging maar. En het kind ging naar de landzijde en zeide aldus: „Grootmoedertje, die jongens, er zijn er maar zes". En de vrouw weende en het kind weende ook.

De vrouw van de māne-hmā maakte warm water en zij begoot de dode jongen er mee, zevenmaal op, zevenmaal neer; de jongen keerde zich om; zevenmaal op, zevenmaal neer, hij stond op, op zevenmaal, neer zevenmaal, hij ging, hij liep. Toen nam de vrouw van de mānehmā kleren en kleedde de jongen. En zij gingen naar de landzijde naar de vrouw (de moeder) en zij riepen. En de vrouw zeide aldus: „Die hier voor roept, deze is gelijk mijn kind!" En de jongen zeide aldus: „Moeder, help me!" En het kind riep weer, de moeder maakte de deur los. En het meisje streek over de borst zittende (?). De jongen streek de broers over hun baard, dat was vlashaar.

Toen het ochtend was liep zij hard weg.

En de māne-hmā zocht zijn vrouw en vond haar niet. Vervolgens riep hij mensen; hij zeide aldus: „Die verkromde scheenbeenderen hebben en die framboesia-puisten aan hun achterste delen hebben en komt naar buiten. Mensen die kromme benen hadden, kwamen naar buiten en daalden neer en zij gingen zij zochten de vrouw van de māne-hmā.

En toen het ochtend was, waren er mensen, die een vaartuig met stokken voortduwden en zij zagen een rookwolkje en zij keerden terug en zij gingen landwaarts naar de māne-hmā en zij zeiden aldus : „Pas op daar boven is een rookwolkje". Vervolgens de māne-hmā hij en zijn volgelingen gingen maar om naar de vrouw van de māne-hmā te zien. 


\section{Salilitá i re Luftá fare ugamtá.}

Kolano pnu pusa, tede, tede bereá.

Salilitá i rea Luftá fare Ugamtá dfān bodiāwa. Smat sitól tasiá dtjaplo pelang pi ulu isa. Fare luftá nsesela po na, Ugamtá ntongaloló, taga Salilitá tja nfamule.

Fare Luftá ntjagu ian na Ugam tja nān be. Fare Luf tja ntolē, fare ntjagu pelang tja, fare nmarapurus. Fare Salili tja n-jas lalei batangi, i re ugam tja. Nane luf tja gabeá n-jas nduk pa. Fare ni falen fen tja ntjapang fare luf tja nua fen tja: „Falen, n-gali ja bonfatobi ja lalei batangi!” Fare fen tja nu laitane: „Gabe laina amgewit nais taok popó tane". Fare luf tja n-gewit nais fen tja tao na. Fare luf tja ndjadji fen tja: „Falen, lomanta lalei batangi, taga jaisewa au!” Fare denabé silalei batangi, fare luf tja fān( nkati mtā na fare nmat.

Fare mnu pa nagá, fen tja nfataga ilalei nagá, lang tja nfabumoi. Fare fen tja n-jāl top na fare nfān. Tòtò tò!

\section{Salilitá re Kakaroutá.}

Mali pnu pusa smat silú dpei bet, fare dtiwa kastèla. Fare smat silú tasiá ddjaga kastèla na, denabé nmasa re nmara. Fare wōl pusa salilitá nua kakaroutá: „Tfān bottjòka kastèla!” Fare kakaroutá n-jāl ni eta tja, fare dfān lalei bet tja loló. Fare dtjòka kastèla, fare dfoiān ga nmasa. Fare dpei bobo, fare kakarou tja ntjabeti. Fare dfān na dlàfa mali laling tja ni fapaluan, fare kakarou tja ni kaluling tja nkakalá nmat. Taga salili tja ntangis fare nfakiko natá saopat tja, fare hnjao tja namorit, fare nmat bená. 
En zij kwamen bij de vrouw van de māne-hmā en zij maakten hun geweren gereed en zij schoten naar boven, want zij bereikten hen niet, totdat zij allen dood waren (n.l. de mensen) en slechts de māne-hmā en zijn vrouw over waren. En men schoot de māne-hmā en hij was dood. Vervolgens zij keerden weer terug landwaarts naar hun plaats.

Het is al uit.

De rode boommier, hij en de muis en het schelpdier.

Een koning in een zekere plaats, men eerbiedige hem maar!

De rode boommier hij en de muis en het schelpdier zij gingen zoeken (op eten uit). Die drie personen zaten op een prauw, een blad van de widar (e.s.v. plant). Vervolgens zette de muis zich aan de voorsteven, het schelpdier in het midden en toen pas de rode boommier op de achtersteven van het vaartuig. En de muis stak vis en het schelpdier at ze maar op. Toen de muis boos en hij stak in de prauw en er kwam een gat in. Vervolgens zwom de rode boommier naar de wal (het land) hij en het schelpdier, maar de muis alleen kon niet zwemmen.

Toen kwam de neef van de muis, de schildpad: „Neef, help me, wil je me geleiden naar land?" En de schildpad sprak aldus: „Als het zo is, klim jij dan hier op mijn rug!" En de muis klom op de rug van de schildpad. Vervolgens beloofde de muis aan de schildpad: „Neef, als we aan de wal zijn, dan geef ik je loon!' En toen zij aan de wal waren, ging de muis suikerriet breken en de bladeren van het suikerriet sneden zijn ogen en hij was dood. Niet zo heel lang daarna volgde de schildpad naar de landzijde en de vliegen omgonsden hem. En de schildpad nam het suikerriet en hij ging weg. Het is gedaan.

\section{De rode boommier en de kreeft.}

In zekere plaats waren twee mensen, zij maakten een tuin, en plantten mais. En die twee mensen bewaakten de mais, totdat zij rijp was. Op zekere dag zeide de rode boommier tot de kreeft: „We gaan, we zullen mais gaan plukken (afbreken)!" En de kreeft haalde zijn kapmes en zij gingen naar de landzijde in de tuin. Vervolgens braken ze de maisvruchten af en kookten eten, totdat het gaar was. Toen maakten zij een draagmand en de kreeft droeg die op zijn rug. Toen zij gingen en halverwege de weg gekomen waren, was de schaal (het schild) van de kreeft rood en hij stierf. Toen pas schreide de rode 


\section{Waga tanpei walit.}

Mali pnu pusa smat silú, mān re mapíng si. Fare wōl pusa dfān dtòta pelang. Fare dtjāl-tjāli lalei nagá, ddem waga isa n-jeli malau npeipei walit. Fare mapíng tja nua ni uattá : „Mjāl(ě) nak waga taie!” Fare mān tja n-jāl waga tja, fare ntjaploi nais pelang tasiá, fare ntjāli lalei. Lalei farea mapíng tja nua ni uattá : „Gabe jai kamtuli, fare mati māni ná waga tja”. Fare mān tja nfaio. Fare mapíng tja namtuli. Mān tja ntutuling fare waga taie npei lio be. Fare mān tja ntolē, fare npesi ga nāni.

Fare mapíng tja npaling nlònga lio pa, fare nfautan: „Janak waga tja imantjawa?” Fare mān tja nu laitane: „Nik le npei liau na, gabe ipesi ga ikāni!’ Mapíng tja nlònga ta mān tja nu laina, fare ntangis nlolam waga tja, fare nfānfān lalei nagá nlònga liau tja mamāngi, fare ilalei, fare nduk gu isa. Fare gu tja nu laitane: „Bomdelluá ?” Fare mapíng tja nu laitane: „Jaboikiāwa waga tanpei walit”. Fare gu tja nu laitane: „Nane ifasawa au!” Fare mapíng tja nailou pa, fare gu tja nilam mapíng tja. Mnu pa nagá mapíng tja ni uattá nfān malī; fare nduk gu tja; fare nfautan: „Mem mapíng isa pa ?” Fare gu tja nu laitane: ,Jaikem smat pa!" Fare mān tja nu laitane : „Gabe awe māni!” Fare dtjapang lalau olatí; fare gu tja amuta mapíng tja.

Fare wōl pusa mān tja nua gu tja: „Au malī, bottjāli!” Fare gu tja nfautan: „Botdelluá ?” Fare mān tja nu: „Botiawa bengan”, fare dtjali. Dlàfo mali sā isa. Fare mān tja nua gu tja: „Msop utjut taie!” Fare gu tja nderera, fare ntjop. Fare mān tja nuwe ga tan-jāl ni ngolotá, fare nfasawa $i$ fawé. 
boommier en snoerde zich de buikband sterk om en zijn buik brak af en hij stierf ook.

(Daarom hebben de kreeften een rode schaal en hangt bij de rode boommieren het voor- en achterlijf slechts door een dun verbindingsstuk samen).

\section{Een cocosnoot, die zong.}

In zekere plaats waren twee mensen, zij waren man en vrouw. Op zekere dag gingen zij een prauw hakken; toen zij naar de wal roeiden zagen zij een cocosnoot, die de rivier afdreef naar zee en die zong. Toen zeide de vrouw tot haar man: „Haal deze mijn cocosnoot!” De man nam de cocosnoot en laadde ze in de prauw, daarop roeiden zij naar het land. Aan wal gekomen zeide de vrouw tot haar man: „Als ik slaap, eet dan de cocosnoot niet op". De man stemde hierin toe. Vervolgens sliep de vrouw. Toen de man alleen was, maakte de cocosnoot lawaai en de man werd boos. Hij sloeg de cocosnoot open en at ze op. Toen de vrouw opstond, hoorde zij geen geluid meer en vroeg: „Waar is mijn cocosnoot ?” Toen sprak de man aldus: „Ik haatte het, dat ze zulk een lawaai maakte, daarom sloeg ik ze door en at ze op". Toen de vrouw hoorde, dat de man aldus sprak, schreide zij, zich haar cocosnoot herinnerende. Toen zij aldoor landwaarts liep, hoorde ze een groot lawaai (rumoer). Aan de landzijde gekomen, vond zij een slang. En de slang sprak aldus: „Waar wilt gij heengaan?” En de vrouw zeide aldus: „Ik wil een cocosnoot zoeken, die zingt”. En de slang sprak aldus: „Ik moet met je trouwen!” De vrouw wilde niet, daarop slikte de slang de vrouw in. Niet lang daarna de man van de vrouw ging hierheen en vond de slang en vroeg: „Hebt gij geen vrouw gezien?” Daarop zeide de slang aldus: „Ik heb geen mens gezien”. Vervolgens zeide de man aldus: „Indien gij ze gegeten hebt?!” En zij gingen naar buiten, naar de zee en de slang braakte de vrouw uit.

Op zekere dag zeide de man tot de slang: „Kom hier! wij zullen gaan roeien!" En de slang vroeg: „Waarheen zullen wij gaan?” En de man zeide: „Wij zullen gaan zoeken (vissen) met de vislijn”. Vervolgens roeiden zij; ze kwamen bij een rif en de man zeide tot de slang: „Duik dit schelpdier op!” En de slang volgde en dook. Daarop keerde de man terug en nam zijn vrouw en trouwde weer met haar. 


\section{Ngolo isa ntu sifit.}

Kolano pnu pusa, tede, tede bereá! Ngolo isa ntu sifít.

Mali pnu pusa ngolo isa ntu sifít. Fare bàhnga tawawai tja nua hnjē : „Ajekē! nim eta leo pa ?” Fare hnjē nu laitane: „Janik eta leo isa taie”. Fare npo lalī ntu si. Fare wawai tja ntok sosobá, fare tòtò, nfasagsagu. Fare hnjē tja nu laitane: „Mati nfasagsagu, mlàfo lalī kolano tja na!” Fare wawai tja nu: „Jailàfo lali pa!" Fare nuwe ian tja ntjuli. Wōl pusa wōl pusa hnjē npei ian laina be.

Fare wōl pusa wawai sifít tasiá dfān dfasagsagu; fare tauatí tja nu laitane: „Ameklàfo lalī kolano tja!” Fare tawawai tja nu laitane : „Mati na o!" Fare tauatí tja ndelai pa. Fare nlàfo lalī kolano tja ni bawa sapngo na, fare kolano tja nem si, fare nololau si. Fare wawai tasiá dfān(ĕ) dumi lalei. Fare kolano tja nfautno si, fare wawai tasiá du: „Amekfasagsagu”. Fare kolano tja nua si: „Meu teno meu tawawai tja ilua ?” Fare tauatí tja nu laitane: „Itaie!” Fare kolano tja nu laitane : „Meufuwe meu teno meu tja nteteam”. Fare siwònam tasiá duwe lalī ebai. Fare hnjēri tja nfautan nu laitane: „Ga tankòri-kòri tja imantjawa ?” Fare tauatí tja nu laitane: „Kolano tja n-jali”. Fare hnjēri ntolē, fare hnjēri nu laitane: „Meu lalau bofjāli !” Silalau nagá kolano tja npuni. Fare siduwe lalei ebai, sidua hnjēri ta: „Ga wawai tja npuni tò!" Fare hnjēri ta ntàngis.

Fare wōl pusa kolano tja nfān lalei nagá nlònga ngolo tja ntangis. Fare kolano tja nlolai, fare $n$-jāl waja sino nduplo wawai tanmat tja, denabé faifit, taga npaling. Fare kolano tja nua wawai tja: „Muwe lalei hnjēm!" Fare nfān lalei hnjē $i$, nlònga hnjē ntangis, fare nua hnjē: „Ajekē! mati mtangis ná tò!” Fare ngolo tja n-jāl ntu tja, fare nfatani, fare n-gopi, fare ngolo tja npei ān, fare ntu tja ntjeli. Fare teno tasiá dfān ddumi, fare mnu pa na, teno tasiá dtjapang malau, fare deme tenori tja fare dtjenga. Fare tauatí tja n-gopi ga nfatani fare n-jāl pake npakei. Fare dòma re malinging wawai tja nfān nfable be. Fare hnjē npei ān inuwe malā ntjeli, fare nfān nfable be. Tòtò tò. 


\section{Een vrouze hebbende zeven kinderen.}

Een koning van zekere plaats, men eerbiedige hem maar! Een vrouw hebbende zeven kinderen.

In zeker dorp was een vrouw met haar zeven kinderen. En eens de jongste zeide tot zijn moeder: „Moeder, hebt gij geen oud kapmes?” En de moeder zeide: „Mijn oude kapmes hier is er een!” En zij gaf het haar kinderen. En de jongens klopten er visstekers van. Toen het klaar was, gingen ze vis steken. En de moeder zeide: „Ga geen vis steken, gij komt daar bij de koning!” En de kinderen zeiden: „Wij komen daar niet bij !' En zij keerden terug, de vis, het was een hoop. Iedere dag maakte de moeder aldus maar de vis.

En op zekere dag gingen die kinderen vissteken, toen zeide de oudste aldus: „Wij komen daar bij de koning!” En de jongste zeide: „Doe dat niet!' En de oudste geloofde hem niet en hij kwam daar voor de deuropening van de koning, en de koning zag hen en hij riep hen. En die kinderen gingen allen naar de landzijde. En de koning ondervroeg hen en die kinderen zeiden: „Wij zijn aan het vissteken!” En de koning zeide tot hen: „Waar is uw jongste broer?” En de oudste sprak aldus: „Hij is hier!” Toen sprak de koning aldus: „Gijlieden keert terug, uw jongste broer blijft!" En die zes keerden naar huis terug. Vervolgens vroeg hen hun moeder, zij sprak aldus : „Wel, waar is de kleine?” En de oudste sprak aldus: „De koning heeft hem gehaald (genomen)". En hun moeder was boos en hun moeder zeide aldus: „Gaat gijlieden naar de zeezijde om hem te halen!" Toen zij aan de zeezijde kwamen had de koning hem al gedood. En ze keerden terug naar huis, zij zeiden tot hun moeder: „Wel, hij heeft dat kind al gedood!" En hun moeder weende.

En op zekere dag ging de koning naar de landzijde en hij hoorde de vrouw maar wenen. En de koning keerde terug en hij nam warm water en begoot de jongen, die dood was, tot zevenmaal, toen pas stond hij op. En de koning zeide tot het kind: „Keer terug tot uw moeder!” En hij ging naar de landzij naar zijn moeder, hij hoorde zijn moeder wenen en hij zeide tot zijn moeder: „Moeder! huil niet!” En de vrouw nam haar kind en zij kuste hem en omhelsde hem en de vrouw bereidde eten en haar kind at. En die broers waren allen gegaan en niet lang daarna kwamen die broers naar de zeezijde (uit het bos) en zij zagen hun broer en zij waren verblijd. En de oudste omhelsde hem en kuste en hij haalde kleren en kleedde hem. En 's morgens en 's namiddags ging de jongen maar spelen. En zijn moeder bereidde eten, hij keerde terug en at en ging maar spelen. Het is klaar. 


\section{Kasturi tá.}

Kolano pnu pusa, tede tede bereá.

Mapíng isa ni kasturi isa. Kasturi tja npeka ian, re pira re pake. Bàhnga kòro isa ntjula ntu isa bonbawi Kasturi tja. Fare wawai tja ilalau nu laitane: „Ja malau boibawi nim Kasturi tja, bon peka na mam ian, re pira re pake”. Fare mapíng tja nua wawai tja: „Amtuba betó, boifatubi subé ga". Fare nua Kasturi tja: au lali peka ian tamajai na, peka pira tamajai na, fare peka obat tadangdang na, fare kabaja tadangdang na, fare geras tadangdang na. Fare nuti lalei; fare kasturi tja npeka ān tamajai re pake tamajai. Fare kòro tja ntjia kibija tja nais nagá, inèm obat tamajai, fare ntole fare ntabo jap bontaping kasturi tja bonfamàti. Fare mapíng tja ilalei kòro tja, bon fautno ni kasturi tja, fare mapíng tja nu laitane: ,Janik kasturi tja imantjá ?” Fare kòro tja nu laitane: mningoi puli jap tja. Fare mapíng tja ntangis fare ntjapang; natalíl nagá, nèmi plu isa fare n-jāli ga, nuti lalau ni ebai. Fare ntjibai mali bla tja, fare nlèsan mali papapo na, fare làtan tja malī, fare salaka re guratji na marapawil nap. Fare njewingi ntjunga lamúl ebai.

Fare bàhnga ninga lalau laisawa mai isa nosal. Fare kòro tja ntjalawe mta na, fare nising lalī ntu tja.

Fare kapal tja imalei, fare mapíng tja ntjung ian isa, ngahnjo mamuli; fare mapíng tja nalan gutji; fare kòro tja ire fakiri isa si malī, fare mapíng tja ntjula kòro tja nfān bon-gon ian, nut salaka re karabu. Fare smat tadwage ian tasiá garajan fare du laitane: kòro taie bàhnga-bàhnga n-gon ian nut salaka re karabu. Fare mān isa nfasau kòro tja, fare nfān lali kòro tja. Tòtò tò. 
Kasturi tá (een soort papegaai, Lorius Garrulus).

De vorst van zekere plaats, men eerbiedige hem maar. Een vrouw, zij bezat (had) een kasturi. Die kasturi hij ontlastte vis en gebakken sagu en kleding. Eens een slavin zij beval een harer kinderen, willende lenen die kasturi. Vervolgens dat kind ging zeewaarts, zeggende aldus : „Ik kom zeewaarts, willende die uw kasturi lenen, om te ontlasten onze vis en gebakken sagoe en kleding". En de vrouw zeide tot het kind: „Ga jij maar eerst, ik zal hem eerst nog maar eens voederen!” Vervolgens zeide zij tot de kasturi: „Gaat gij daarheen en ontlast slechts vis, die slecht is, ontlast gebakken sagoe, die slecht is en ontlast sarongs, die doorschijnend dun zijn en baadjes, die doorschijnend dun zijn en katoenen stof, die doorschijnend is". Toen bracht zij hem landwaarts en de kasturi ontlastte eten, dat slecht was en kleding, die slecht was. En de slavin zij opende haar doos (kist) en zij zag slechts sarongs, vervolgens zij was boos en zij stak vuur aan, willende de kasturi verbranden, om hem te doden. Vervolgens de vrouw zij ging landwaarts om haar kasturi te vragen. En de vrouw zeide aldus: „Mijn kasturi, waar is die?” En de slavin zij zeide aldus : „Kijk daar naar het vuur”. Vervolgens de vrouw zij weende en ging naar buiten. Buiten gekomen zijnde, zij zag maar een veer en zij nam die en zij bracht die zeewaarts naar haar huis en zette die overeind op haar erf en zij veegde er onder. En de wind kwam hierheen en zilver (arm- en beenringen) en goud (oorversierselen) vielen naar beneden en zij verzamelde die en zij ging er mee naar binnen in haar huis. En eens zij zag zeewaarts gelijk een steel van een harpoen, hij stond overeind. Vervolgens de slavin zij maakte los haar ogen en plaatste ze derwaarts naar haar kind.

En het schip het kwam naar de landzijde en de vrouw zij werd een vis, genaamd mamuli ${ }^{\mathbf{1}}$ ) en de vrouw zij rangschikte schotels en de slavin zij en een oude vrouw ${ }^{2}$ ) zij kwamen herwaarts en de vrouw zij beval de slavin, en zij ging willende (om te) kopen vis en zij bracht (droeg) zilveren armbanden en beenringen en oorversierselen. En de vishandelaars zij waren verbaasd en zij zeiden aldus: „Deze (is een) slavin, elke dag (telkens weer) zij koopt vis en draagt zilveren armbanden en oorversierselen!" Vervolgens een man hij trouwde de slavin en hij ging derwaarts naar de slavin. Het is af ${ }^{3}$ ).

1) mamuli, e.s.v. vis.

2) fakiri = Mal. kabajan.

3) Het laatste gedeelte van dit verhaal is nogal onsamenhangend en daardoor niet zeer verstaanbaar. 


\section{Wàmatá.}

Kolano pnu pusa, tede, tede bereá. Wàmatá.

Wàmatá ni ngolo silím. Isa ngahnjo Kanelangit, isa ngahnjo luf, isa ngahnjo kasturi, isa ngahnjo bereák, isa ngahnjo buta. Bang sa fare wàma tja ndāl(ĕ) nmat. Fare kanelangit tja nua nidel na: „Noke, tameu! rir uat tja nmat". Fare dtangis.

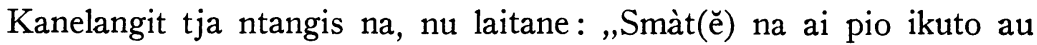
malī, weli be màto ja be!” Luf tja ntangis na, nu laitane: „Smàt(̌̌) na pupi ikuto au malī, weli be màto ja be!" Kasturi tja ntangis na, nu

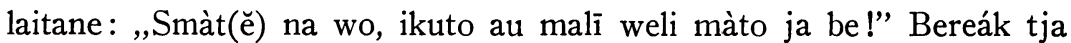

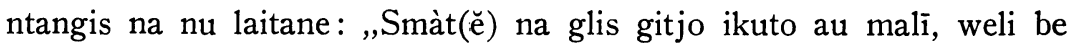
màto ja be!" Buta tja ntangis na, nu laitane: „Màgal tantena lalei weli

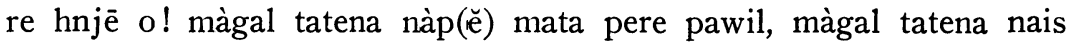
kaere mamo he! màgal tantena lalau salaka re guratji”. Fare wàma tja namlif. Tòtò tò.

\section{$\mathrm{XV}$. Uahleo isa re ngolo isa si re nturi mān sifit.}

Kolano pnu pusa, tede, tede bereá! Ngolo isa re uahleo isa si re nturi mān sifít.

Fare wōl pusa wawai tasiá dua hmā re hnjē si : „Amam taine djumat

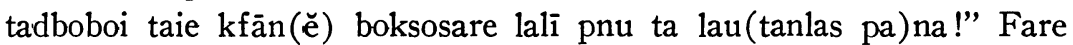
uahleo tja nu laitane: „Mama tameu, fān bereá mati flàfo kolano Lalim ni pnu ná; gabe meu flàfo lalī kolano tja ni pnu, osetane npun meufít taine ó!” Fare wawai tasiá du laitane: „Osetane klàfo lalī pa, las pa ga kolano tja ni pnu na!"

Fare wawai tasiá riri djumat tja nlàfo, tò, fare dfān. Farea dlàfo mali pnu pusa, fare dwagaf ga dfautan kolano Lalim ni pnu tja mantjawa? Fare smat tamaná na du laitane: „O! kolano tja ni pnu nalas pa!" Fare wawai tasiá dfapepea riri pelang tja fawé mali pnu tja. Fare riri pelang tja tòtò, fare dfān fawé. Wawai tasiá dfalai mali olat mamàgal tja. Fare tauati tja nua tawawai tja: „Tofnga mòsal puis failān tja pu, bomningo lalau fare lalei!" Fare wawai tja nòsal nais failān ni pu tja, fare ninga lalei, pa-isa pa: ninga lalau na, nem nus 


\section{De jaarvogel.}

De koning van zekere plaats, men eerbiedige hem maar. Wàmatá. De jaarvogel had vijf vrouwen. Een haar naam was kanelangit (e.s. vogel); een haar naam was muis, een haar naam was kasturi (e.s. papegaai), een haar naam was bereák (e.s. vogel) en een haar naam was duif.

Eens de jaarvogel deed het voorkomen, hij was dood. En de kanelangit zeide tot haar metgezellinnen: „Vriendinnen! die gijlieden! onze man, hij is dood". En zij weenden. De kanelangit zij weende, zeggende aldus : „De boomvruchten van de mensen, breng ik U hierheen, ware ik slechts met U gestorven!” De muis zij weende, zeggende aldus : „Het sagoemeel van de mensen, ik breng dat $U$ hierheen, ware ik maar met $U$ gestorven!” De kasturi zij weende, zeggende aldus: „De palmwijn (tureak) v. d. mensen, ik breng die voor $U$ hierheen, ware ik slechts met U gestorven!” De bereák zij weende, zeggende aldus : „De glisgitjo (de bast v.d. glis, een s. boom) van de mensen ik breng die hierheen voor U, ware ik maar met U gestorven!' De duif zij weende, zeggende aldus ${ }^{1}$ ) : ,de tak, die zich uitstrekt landwaarts ....; de tak, die zich uitstrekt naar beneden....; de tak, die zich uitstrekt naar boven....; de tak, die zich uitstrekt naar de zeezijde zilver en goud". Vervolgens de jaarvogel hij lachte. Het is klaar.

\section{Een oude man en een vrouze zij en hun zeven zonen.}

Een koning van zekere plaats, men eerbiedige hem maar! Een vrouw en een oude man zij en hun zeven zonen. En op zekere dag die kinderen zeiden tot hun ouders: „Onze week die nu voor ons is, gaan wij om levensonderhoud te zoeken naar verre plaatsen". En de oude man zeide aldus: Gij vadertjes, als gijlieden dan maar gaat, wilt dan niet komen in het dorp van koning Lalim (onrechtvaardig), indien gijlieden komt in het dorp van koning Lalim, zekerlijk hij doodt u zeven, hoor!" En de kinderen zeiden aldus : „Zekerlijk wij komen daar niet, want het dorp van die koning is niet dichtbij!"

En die kinderen hun week was er en zij gingen. Toen zij in zekere plaats kwamen, gingen $z \mathrm{ij}$ aan land en $z \mathrm{ij}$ vroegen, waar het dorp van koning Lalim was. En de mensen daar zeiden aldus: „O, die koning zijn dorp is niet dichtbij!" En die kinderen maakten hun prauw weer gereed in dat dorp. Toen hun prauw klaar was, gingen zij alweer. De

1) Hetgeen de duif hier zegt is ten dele voor mij onverstaanbaar. 
isa, laisawa ubi isa ntatop. Fare wawai tja nduri fare nua teno tanmamàgal tja nu laitane: „Nane tadbo lalau tane kem nus isa!” Fare sidfalai na dtelma nus tja, denabé demi mafia. Fare denabé dem ebai na, fare wawai tasiá dninga lalei nagá dem kolano ni kadato tja. Fare wawai tauati nwagaf lalei pnu tja. Fare smat tasiá dutani: Taina nim susa ahai fare nim kapalang ahai? Fare inu: nik susa paisa pa, fare nik kapalang paisa pa; renta mān ja ga ifān ja! Fare dòram tja kolano ni kòro isa ilalau nut kolano ni jali-jali pusa, fare npo mali pelang tja ni smat na. Dòram tja kolano tja nfasula diāwa jali-jali tja, denabé sema duki pa. Fare ntjula dbubit pelang tja malei, fare diāwai mali pelang tja lolò na, denabé dduki. Fare kolano tja nfasula dpunsi (tji). Fare smat mali pnu tja du laitane: „Djou kolano, mati mpuntji ná, nane mjāltji, bompeio nim kòro si !' Fare kolano tja n-jāl tji ga npeio ni kòro si, denabé kolano tja nmat, mai simalī kolano tja ni ebai loló.

Tòtò tò.

\section{Kolano isa ntu sifit.}

Kolano pnu pusa, tede, tede bereá. Kolano isa ntu sifít.

Mali pnu isa kòro isa ntu mān isa. Fare wawai tja nmamàgal, fare nua hnjē: „Au lalau kolano tja bomdor pinge”. Fare hnjē nu laitane: „Mama e! ite kòro ite ga mati tdor mali kolano tja ná !" Fare wawai tja nu laitane: „Tjè! au lalau betó; fare hnjē tja lalau, fare ntotoláng potalil na".

Fare kolano tja nu laitane: „Ise tja ?” Fare kolano tja ni kòro na du laitane: „Mapíng majai isa”. Fare kolano tja ntjapang natá. Fare kolano nu laitane: „Bomdelluá ?” Fare mapíng tja nu laitane: „Ja malau boidor pinge”. Fare kolano tja nua ni kòro na laitane: „Fsung lamúl, bofjāl pinge karong pusa, bofòtje na i’. Fare kòro tasiá d-jāl pinge karong pusa, bodòtje mapíng tja na i. Fare mapíng tja nuwe lalei, fare wawai tja ntopa. Fare sema tja fawé wawai tja ntopa. Fare 
kinderen zeilden op de grote zee. En de oudste zeide tot de jongste: „Probeer eens op te staan boven bij het ondereind van de mast om te kijken naar de zeezijde en naar de landzijde!' En de jongen stond op bij het ondereind van de mast en hij keek naar de landzijde, en er was niets; en hij keek naar de zeezijde en hij zag een eiland als een halve cocosschaal, die onderste boven lag. En de jongen kwam naar beneden en zeide tot zijn grote broer, hij zeide aldus: „Zeker, dat we voor ons hebben zeewaarts hier zie ik een eiland!' En zij zeilden en zij richtten zich naar dat eiland, totdat zij het goed zagen, toen totdat ze de huizen zagen en die kinderen keken naar de landzijde en daar zagen zij maar het paleis van de koning. En de oudste jongen ging aan wal in die plaats. En de mensen vroegen hem: „Nu wat hebt gij voor moeite, wat hebt ge voor hoofdbrekens?” En hij zeide: „Ik heb heel geen moeite, ik heb heel geen hoofdbrekens, omdat ik man ben, daarom ben ik er op uit gegaan!" Toen het avond was kwam er een slaaf van de koning zeewaarts, hij bracht een ring van de koning en gaf die aan de mensen van de prauw. Die nacht beval de koning, dat ze zijn ring zouden zoeken, tot de morgen (zochten ze) zij vonden hem niet. Toen beval hij de prauw op te trekken naar de landzijde en zij zochten in de prauw, totdat ze hem vonden. En de koning beval hen te doden. En de mensen in het dorp zeiden aldus: „Heer koning, dood hen niet, maar neem ze en maak ze tot uw slaven!" En de koning nam hen en maakte hen tot zijn slaven, totdat de koning dood was, maar zij waren hier in het huis van de koning. Het is klaar.

\section{Een koning en zijn zeven kinderen ${ }^{1}$ ).}

Een koning van zekere plaats, men eerbiedige hem maar. Een koning en zijn zeven kinderen.

In zekere plaats was een slavin, haar kind was een jongen. Toen het kind groot was, zeide het tot zijn moeder: Gaat gij zeewaarts naar de koning, willende (om te vragen) gij vragen rijst. En de moeder zeide aldus : „Vadertje wij zijn maar slaven wij, laat ons niet vragen dat aan de koning”. En het kind zeide aldus: „Foei, ga gij slechts zeewaarts”. Vervolgens de moeder zij ging zeewaarts en zij zat buiten. En de koning sprak aldus: „Wie is dat?” En de slaven van die koning zij zeiden aldus: „Een mindere vrouw”. En de koning hij ging naar buiten. En

1) Het opschrift ,en zijn zeven kinderen” schijnt me niet juist, daar er geer. woord over de zeven kinderen in het verhaaltje voorkomt. 
sema tja fawé wawai tja ntjula hnjē lalau fawé, bondor geras, fare dòtje i, fare nut lalei. Fare wawai tja ntopa fawé.

Fare malingin tja pòna wawai tja ntjula hnjē fawé, fare hnjē nu laitane: „Mame e! Kolano tja nòtje it pantó”. Fare wawai tja nu laitane: „Tjé, au lalau betó”. Fare hnjē lalau bondor obat; fare kolano tja nòtje $\mathrm{i}$ obat; fare nut lalei, fare wawai tja ndjaga ntopa.

Fare wōl pusa kolano tja ntu mān isa nfān lalei mapíng tja ire ntu tja; fare kolano ntu tja nu laitane: „Meu na meu ān re meu ni meu pake tja nmantjá?” Fare wawai tja nu laitane: „Jai topa!” Farea kolano ntu tja ntolē, fare wawai tja ilalau kolano tja, ga nfabinga kolano tja. Fare kolano ilalei mapíng tja ire wawai tja; fare kolano tja nu: „Meu ni meu pake imantjá? Fare meu na meu ān na imantjá ?” Fare wawai tja nu laitane: ,Jai topa!” Fare kolano tja ntolē na mafia pa, uhngo tja nkakalā. Fare kolano tja nuwe lalau ebai, fare nu laitane: „Ikòtje simpantò, maske simalau boddor, ikòtje si pantò”. Tòtò tò. 
de koning sprak aldus: „Waar wilt gij heengaan?” En de vrouw sprak aldus : „Ik kom naar de zeezijde ik wil vragen rijst”. Vervolgens de koning zeide tot zijn slaven aldus : „Gaan jelui naar binnen, willen (om te halen) gijlieden halen rijst een zak, om die gijlieden te geven aan haar". Vervolgens die slaven zij haalden een zak rijst, om die te geven aan die vrouw. En de vrouw keerde terug landwaarts. Vervolgens het kind hij gooide het weg.

Toen het weer morgen was, beval het kind weer zijn moeder weer zeewaarts te gaan, om katoenen stof te vragen. En zij gaven het haar, en zij bracht het landwaarts, en het kind hij gooide het weer weg.

Toen het namiddag was, het kind hij beval zijn moeder weer en zijn moeder zeide aldus : „Vadertje! de koning hij geeft ons niet meer”. En het kind zeide aldus : „Foei, gaat gij maar zeewaarts”. En zijn moeder ging zeewaarts om te vragen sarongs. En zij bracht die landwaarts en het kind hij wachtte ze op, hij gooide ze weg.

Vervolgens op zekere dag de zoon van de koning hij ging landwaarts naar de vrouw en haar kind. En de zoon van de koning, hij sprak aldus: "Jelui eten en jelui kleren, waar zijn die?" En het kind zeide aldus: „Ik, ik gooide ze weg”. Vervolgens de zoon van de koning hij was boos. En de zoon van de koning hij ging zeewaarts, vervolgens gaf hij kennis aan de koning. Toen ging de koning landwaarts naar de vrouw en haar kind en de koning zeide aldus: „Waar is jelui kleding en waar is jelui eten?” En het kind zeide: „Ik, ik gooide 't weg”. En de koning werd boos, zijn aangezicht werd rood. En de koning hij keerde terug naar zijn huis en hij zeide aldus: „Ik geef hun niet meer, ofschoon zij zeewaarts komen om te vragen, ik geef hun niet meer". Het is klaar. 


\section{Bidulu miskin.}

Kolano pnu pusa, tede, tede bereá. Bidulu miskin.

Mān isa ire ni ngolotá fare nturi mān isa, ngahnjo Bidulu miskin. Wōl pusa Bidulu miskin nuwa hnjē nu laitane : ,Jaboifān(ě), boifasau. Fare hnjē nu laitane: „A ulom betó. Wōl pusa Bidulu miskin nuwa hnjē nu laitane fpei nak ān tela fapifít, kupa fapifít fare kastela fapifít. Fare djumat tja nfān. Fare nlàfo mali pnu isa tjitjapo, fare ntjaplo kareta isa fare nfān. Fare nlàfo mali pnu isa fawé. Fare Bidulu miskin nuwa mapíng na nu laitane: „Fdinge nik pake tane”. Fare mapíng na ding.

Wōl pusa Bidulu miskin nuwa ni kòro isa, nfān fatobi kareta isa mali hmā re hnjē. Fare kòro tja nut kareta tja, nfān, fare ndel mali pāt na popó. Fare npei walit. Fare Bidulu miskin hnjē nlònga, fare nu laitane: „Ise tanpei walit ta polau tai, laisawa ntuk tja ?” Fare ntangis

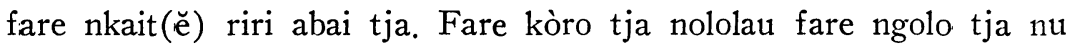
laitane: „Ise ta nololau laisawa ntuk tja?” Fare kòro tja nu laitane: „Gabe ja!" Fare ngolo tja ntjupat bawa tja. Fare kòro tja npo kareta tja lalī, fare kòro tja nu laitane: „Bidulu miskin nmat(ě) tó”. Fare ngolo tja ntangis, fare nuwa ni uattá, nu laitane: „Au lalei beti bon-jāl tela wa isa botpei lupas". Fare ni uattá ilalei beti $n$-jāl tela isa, fare dòram tja dpei ān, sema tja fare dpei rame isa, fare smat ta mali pnu tja silalī dumi fare dtjeli. Fare dem Bidulu miskin nfān malī, fare smat na duwa Bidulu miskin hmā re hnjē si du laitane: „Bidulu miskin tanfān malī tai”. Fare Bidulu miskin hmā re hnjē si dtangis. Tòtò tò. 


\section{Bidulu miskin.}

De koning van zekere plaats, men eerbiedige hem maar. Bidulu miskin.

Een man hij en zijn vrouw en hun kind (zoon) een, zijn naam was Bidulu miskin. Op zekere dag Bidulu miskin hij zeide tot zijn moeder, hij zeide aldus: „Ik wil gaan, ik wil trouwen”. En zijn moeder zeide aldus: „Uw wil slechts”. Op zekere dag Bidulu miskin zeide tot zijn moeder aldus : „Maakt gijlieden mijn eten, bananen zeven stuks, katupat zeven stuks en mais zeven stuks". Toen het Vrijdag was, hij ging. En hij kwam aan het eind van een dorp, vervolgens hij nam plaats op een karretje en hij ging. En hij kwam weer in een dorp. Vervolgens Bidulu miskin hij zeide tot een vrouw zeggende aldus: „Naait gijlieden nu mijn kleren". En de vrouw naaide ze. Op zekere dag Bidulu miskin zeide tot een van zijn slaven, hij gaan brengen van zijn vader en moeder een karretje. En de slaaf ging bracht het karretje, hij ging en hij volgde boven op de stenen en hij zong liedjes. En de moeder van Bidulu miskin hoorde dat, zij zeide aldus : „Wie, die hij zingt liedjes aan de zeezijde hier gelijk mijn zoon?" En zij weende en grendelde de deur van hun huis. Vervolgens de slaaf hij riep en de vrouw zij zeide aldus: „Wie, die daar roept gelijk mijn zoon die?” Vervolgens de slaaf hij zeide aldus: „Indien ik”. En de vrouw ontsloot de deur. En de slaaf hij gaf het karretje herwaarts, vervolgens de slaaf hij zeide aldus: „Bidulu miskin hij al dood”. En de vrouw zij weende en zij zeide tot haar man, zij zeide aldus: „Gij ga landwaarts naar de tuin willende halen een banaan, wij zullen maken een dodenfeest (maal)". Vervolgens haar man hij ging naar de landzijde naar de tuin willende hij halen (om te halen) een banaan; toen het avond was, zij maakten eten; 's morgens zij maakten een feest en de mensen in het dorp zij kwamen daarheen, zij allen en zij aten.

En zij zagen Bidulu miskin hij kwam hierheen en de mensen zeiden tot de ouders van Bidulu miskin, zeiden aldus: „Bidulu miskin, die hij (komt) gaat hierheen". En zij Bidulu miskin's ouders, zij weenden. Het is al klaar. 
XVIII. Ding ding ese. - Enige kinder(wiege)liedjes. Ding ding ${ }^{1}$ )

1. Jantuk mta mlànga Mijn kind heeft lange ogen ${ }^{2}$ ) boboko blewing golo zijn hoofdhaar ${ }^{3}$ ) is (als) een loophoenpugau tamate, bawa, zijn haarspeld, tomaten, uien ${ }^{4}$ ) ndòmo sapa, gutji pa het drinkt niet uit een kom of bord ndòmo be genini ulū. het drinkt slechts uit een genini-blad ${ }^{5}$ ).

Ding ding

2. Fnai ailú, fnai ai tjól, Twee stuks fnai (e.s. bamboe), drie

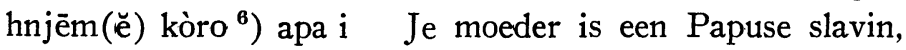
hmam $(\breve{e})$ bala po $^{7}$ ). Je vader is een vrij gelaten Papua.

\section{Ding ding}

3. Mdel ta polau natju- Gij volgt de weg naar de zeezijde, [tjuraf tapolei hij maakt het geluid (waarmee men [honden lokt) aan de landzijde, Mdel, ta polei natju- Gij volgt de weg naar de landzijde, [tjuraf ta polau. hij maakt dat geluid van de zeezijde.

(ziet mogelijk op de verplichte gehoorzaamheid aan de beide ouders).

\section{Ding-ding}

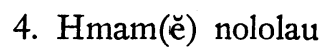
msanglo Djou!

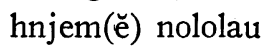
msanglo Djou! amdel fapaluan.
Je vader roept, gij antwoordt Djou (Heer)! Je moeder roept, gij antwoordt Djou (Heer)! gij volgt in het midden.

1) ding-ding is steeds de inleiding tot het liedje.

2) boboko blewing golo; boboko, hoofd, hier figuurlijk hoofdhaar; blewing, e.s. loophoen; golo, staart.

3) lange ogen, ogen zoals bijv een Chinees heeft.

4) tomaten en uien worden door de vrouwen in de haarwrong gedragen als geesten-verdrijvend-middel.

5) genini, e.s. broodboom (Mab.), Bul. gawin.

B) kòro, krulhaar, kroeskop. Alle slaven waren vroeger Papua's, daarom ook: slaaf.

7) bala po of ook wel bala baru, nieuwe onderdaan, vrijgelaten slaaf. 
(het kind wordt hier onderricht hoe het zich te gedragen heeft tegenover de ouders).

\section{Ding-ding}

5. Djou tja nduri e

De heer hij daalt neer

na waja isilāng

na ian djeke, zijn water is Mohammedaans ${ }^{1}$ )

na pira nau. zijn vis is djeke ${ }^{2}$ )

zijn sagoekoeken zijn $n a u^{3}$ ).

(dit liedje bevat waarschijnlijk een waarschuwing aan de levenskracht van het kind, om de geesten niet te volgen, bij welke alles minderwaardig is!).

1) waija Isilāng, Mohammedaans water. Ziet op het Mohammedaans worden, waar de Buliërs niet toe geneigd waren.

2) iam djekc, een zeer giftige vissoort.

3) De koeken van de sagumau (arenpalm) zijn van een minderwaardige soort sagoe. 


\section{Tjagulu ese. - Enige raadsels.}

1. Leslesan olat een zeeveger (bezem) antw. labang (treknet, zegen).

2. Tuan na riri ngolo pa

die heren zij hebben geen vrouw

, sapa (kom, zonder

3. Dramean ailoló muziekinstrument in schoteltje). het hout (bos)

4. Smat diāwa ān mensen zij zoeken dānpa, dòtje $\operatorname{smat}(\breve{e}) n a$ eten, zij eten niet zij geven het mensen

5. Smat isa ifitjo na wala een mens zijn benen zijn touw

" kander wrijvende takken.

, ban, strikken.

6. Ai sáwatja tān

7. Bengan tanat slubisá, mlànga tatalē tolo pusa

8. Smat isa ifitjo na tadui, boboko tja sisei een boom zijn wortels wij eten

een vislijn van honderd vadem, zijn lengte een kippenei een mens zijn benen zijn gespoord zijn hoofd heeft een haarkam

9. Nus isa tanfänfān

een eiland, dat

wandelt

10. Bai iboboko guratji

11. Tòta pàt, tòta waja

12. Ebai isa, bawa silim, fare kakait silim een Pythonslang zijn kop is van goud stenen hakken, water hakken

een huis met vijf deuren en vijf grendels (afsluitbomen)
" labang (treknet, zegen).

, asbi, cassave $m t a$, het oog.

, tatalē mān, de haan.

" tudjunge, e.s. waterplant (Nymphe Lotus).

" bengan, een vislijn.

" waga, cocosnoot.

„ kabaja, een mannenbaadje. 
I N H O U D.

TOQR.

VOORBERICHT . . . . . . . . . . . 3

1. INLEIDING . . . . . . . . . . . . . . 5

2. KLANKSTELSEL EN SPELLING . . . . . . 13

1. Het vocalisme . . . . . . . . . . . 13

2. Het consonantisme . . . . . . . . . . 15

3. Klemtoon . . . . . . . . . . . . 17

4. Spelling . . . . . . . . . . . . 17

5. Enige opmerkingen van taalvergelijkende aard . . . 18

6. Woordvorm . . . . . . . . . . . 21

3. VORMLEER . . . . . . . . . . . . 25

I. Het zelfstandig naamwoord . . . . . . . 25

1. Grondwoorden . . . . . . . . . 25

2. Grondwoorden + reduplicatie of geminatie . . 25

3. Grondwoorden + bepaalde affixen . . . . 26

4. Combinaties van grondwoorden . . . . . 30

5. Geslacht . . . . . . . . . . . 31

6. Getal . . . . . . . . . . . 31

7. Constructies met $n i, n a$ en $o$. . . . . . $\quad 32$

8. Constructies met $-a,-o,-e,-e a$ en $-e o$. . . . 33

II. Het bijvoeglijk naamwoord . . . . . . . 34

1. Grondwoorden . . . . . . . . . 34

2. Grondwoorden met reduplicatie of geminatie . . 34

3. Grondwoorden met een affix . . . . . . 35

4. Predicatief gebruik . . . . . . . 36

5. Attributief gebruik . . . . . . . . 37

6. Zelfstandig gebruik . . . . . . . . . 37

7. Trappen van vergelijking . . . . . . 38

III. Het telwoord . . . . . . . . . . 40

1. Hoofdtelwoorden . . . . . . . . 40

2. Classificerende hulptelwoorden . . . . . 41

3. Rangtelwoorden . . . . . . . . . 43 
4. Vermenigvuldigende telwoorden en breuken . 44

5. Verdelende telwoorden . . . . . . . 44

6. Onbepaalde telwoorden . . . . . . . . 45

IV. Het voornaamwoord . . . . . . . . 47

1. Aanwijzende voornaamwoorden . . . . . 47

2. Persoonlijke voornaamwoorden . . . . . 48

3. Bezittelijke voornaamwoorden . . . . . 52

4. Vragende voornaamwoorden . . . . . . 56

5. Onbepaalde voornaamwoorden . . . . . 56

6. Betrekkelijke voornaamwoorden . . . . . 58

V. Het werkwoord . . . . . . . . . . 60

1. Grondwoorden en combinaties van grondwoorden 60

2. Geredupliceerde grondwoorden . . . . . 61

3. Combinaties van grondwoorden en voorvoegsels, met verbale betekenis . . . . . . . 63

A. Grondwoorden met de prefixen $m a-, a m-, m-$, $a$ - en mara- . . . . . . . . . . 63

B. Grondwoorden met het prefix fa- . . . . 67

4. Grondwoorden van suffixen voorzien . . . . 73

5. Enige wat samenstelling betreft niet duidelijke verba . . . . . . . . . . . 80

6. Wijzen van het werkwoord . . . . . . 80

7. Tijden van het werkwoord . . . . . . 84

8. Vervoeging van het werkwoord . . . . . 85

VI. Het bijwoord . . . . . . . . . . . 88

1. Vorm . . . . . . . . . . . 88

2. Betekenis . . . . . . . . . . . 90

A. Bijwoorden van plaats . . . . . . 91

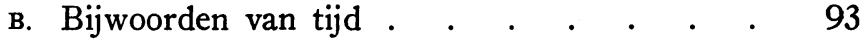

C. Bijwoorden van causaliteit . . . . . 95

D. Bijwoorden van hoedanigheid en hoeveelheid 95

E. Bijwoorden van modaliteit . . . . . 97

VII. Voorzetsels . . . . . . . . . . 100

VIII. Voegwoorden . . . . . . . . . . 103

IX. Tussenwerpsels . . . . . . . . . . . 106

TEKSTEN . . . . . . . . . . . . 107 